\title{
Guns and shikaris: The rise of the sahib's hunting ethos and the fall of the subaltern poacher in British India, 1750-1947
}

\author{
Fiona Mani \\ West Virginia University
}

Follow this and additional works at: https://researchrepository.wvu.edu/etd

\section{Recommended Citation}

Mani, Fiona, "Guns and shikaris: The rise of the sahib's hunting ethos and the fall of the subaltern poacher in British India, 1750-1947" (2012). Graduate Theses, Dissertations, and Problem Reports. 594.

https://researchrepository.wvu.edu/etd/594

This Dissertation is protected by copyright and/or related rights. It has been brought to you by the The Research Repository @ WVU with permission from the rights-holder(s). You are free to use this Dissertation in any way that is permitted by the copyright and related rights legislation that applies to your use. For other uses you must obtain permission from the rights-holder(s) directly, unless additional rights are indicated by a Creative Commons license in the record and/ or on the work itself. This Dissertation has been accepted for inclusion in WVU Graduate Theses, Dissertations, and Problem Reports collection by an authorized administrator of The Research Repository @ WVU.

For more information, please contact researchrepository@mail.wvu.edu. 
Guns and shikaris: the rise of the sahib's hunting ethos and the fall of the subaltern poacher in

British India, 1750-1947

\author{
Fiona Mani \\ Dissertation submitted to the \\ Eberly College of Arts and Sciences \\ at West Virginia University \\ In partial fulfillment of the requirements \\ For the degree of \\ Doctor of Philosophy \\ in \\ History
}
Joseph Hodge, Ph.D., Chair
Robert Maxon, Ph.D.
Mark Tauger, Ph.D.
James Siekmeier, Ph.D.
Gregory Barton, Ph.D.

Department of History

\begin{abstract}
Morgantown, West Virginia
2011
\end{abstract}

Keywords: British, India, Hunting, Masculinity, Femininity, History, European History

Copyright 2011 Fiona Mani 


\begin{abstract}
Guns and shikaris: the rise of the sahib's hunting ethos and the fall of the subaltern poacher in British India, 1750-1947
\end{abstract}

\title{
Fiona Mani
}

This dissertation examines the history of hunting in India under British colonialism, but with some background on earlier periods and a brief discussion on Nepal and successor states of India, Pakistan, Bangladesh. The study relies on Indian and British sources including private papers, memoirs, books, and official records. It examines hunting by different native groups in India, British men and women, and considers the relationship of hunting to political authority, gender identity, and conservation and the environment.

Before the British takeover of India, the country had a hunting tradition that included royal hunting and tribal hunting. The British also had a hunting tradition dating back to the Middle Ages that generally limited hunting rights to the aristocracy and the royals and restricted/ prohibited hunting by other groups, which in some classes was classed as poaching. As the British extended control over large areas in the late $18^{\text {th }}$ century, the British connected themselves with princely rulers to gain legitimacy. This shared activity resulted in a blending of British and Indian hunting traditions and gave rise to what I call the Anglo-Indian hunting tradition.

Hunting was connected with masculinity generally, yet a small number of women also participated. The Anglo-Indian hunting tradition also involved employment of shikaris due to their expert knowledge, but the British were critical of shikaris often because they were seen as poachers and hunted without guns, which some British men viewed as "feminine." Nevertheless, the Anglo-Indian hunt crossed social and communal boundaries as the British established strong bonds with their shikaris. The British hunting tradition emphasized paternalism congruent with the benevolence of imperialism. This tradition developed in the $19^{\text {th }}$ century. British men like Jim Corbett hunted to protect Indians from the depredations of wild animals like tigers or leopards.

During the $19^{\text {th }}$ century British sportsmen and especially Indian princes killed large numbers of animals in their hunt. By the late $19^{\text {th }}$ and certainly by the $20^{\text {th }}$ century declining numbers of game animals persuaded British hunters and officials to establish a system of laws, licenses and permits to regulate and limit hunting and suppress poaching. The British sportsman of the $20^{\text {th }}$ century was a gentlemanly, refined hunter whose primary characteristic trait was a sense of restraint and a strong sense of ecological awareness. Hunting retained its imperial legacy well into the post-colonial period as Indian hunters took up the mantle of the British out of a moral desire and continued to protect Indians from wild animal disturbances. 


\section{Table of Contents}

Introduction

Chapter 1: Hunting in Britain -Eighteenth to the Twentieth Centuries

Chapter 2: Shikar: The Regal Sport of the Sahibs and Nawabs in India Before 1800

Chapter 3: Shikar: the Regal sport of the Sahibs and Maharajas in colonial India, 1800-1899.

Chapter 4: Hunting and British hunters in colonial India, 1900-1947: New Technology, Humanitarian Hunters, and Growing Conservationist Awareness.

Chapter 5: Hunting and Imperialism: Indigenous Hunters in colonial India, 1900-1947

Chapter 6: British Women and their Hunting Experience in the Raj, 1830-1947

Chapter 7: Regulation of Hunting in the late 19th and 20th centuries

Conclusion 


\section{Introduction:}

This dissertation explores the place and nature of hunting in colonial India and the onset of conservationist ideologies that arose from rampant, unchecked shooting in the late $19^{\text {th }}$ century by both the British and Indians. Hunting was an obsession for the British in India in the $19^{\text {th }}$ century and remained so until the end of the Raj in 1947 . My argument is that the hunting practices that developed in colonial India were not directly imported from Britain, but rather, were an amalgam of the hunting traditions of England and India that were also tailored to the environment and had their own laws and meanings. In other words, it is more accurate to speak of an "Anglo-Indian" hunting tradition. Hunting in colonial India, was not a British practice imposed on India based on British experience. The Anglo-Indian tradition differed from both British hunting at home and Indian hunting of the pre-colonial period. The definition of Anglo-Indian here is simply a combination of Indian and British practices. The $20^{\text {th }}$ century also saw the rise of a refined, gentlemanly hunter who restrained himself from excess hunting. Masculine dexterity was now evident in those he commanded under him in the organized hunt and in his marksmanship, rather than in his physical prowess. This study examines the formation and character of Anglo-Indian hunting with particular focus on race, gender and class to deconstruct social relations between Indians and the British. The new hunting tradition marked a refined gentlemanly hunt which relied on guns, shikaris or native hunters, beaters and which followed various hunting laws. It also led to a distancing 
between Indian hunters and refined British sportsmen during the shift to preservation and conservation.

The dissertation also includes a comparison of hunting practices in Britain to delineate the differences of British hunting from that of Indian hunting practices, as well as the similarities between them that were incorporated into Indian hunting to create the Anglo-Indian hunting tradition. In Britain, there was a distinct hunting tradition associated with aristocrats and the landed gentry that arose during the $18^{\text {th }}$ century. While Britain also had a tradition of poachers, various Game Acts were implemented to curtail the activities of the poacher. By the late $18^{\text {th }}$ century, gentlemanly hunters distinguished themselves from poachers and prided themselves on their hunting etiquette, natural history knowledge, and veterinary skills. By the $19^{\text {th }}$ and $20^{\text {th }}$ centuries, gentlemen and gamekeepers along with huntsmen and whippers-in who are basically huntsmen's assistants that keep hounds in a line are no longer the only hunters. Females and other sportsmen who enjoyed recreation including working-class sportsmen joined the hunting milieu although the latter were never accepted as "hunters" mainly because they engaged in blood sports.

In India, there were three distinct hunting traditions prior to British arrival: those of the princes, village commoners, and tribals. After the British came to India, a new hunting tradition developed that was distinctively Anglo-Indian. This tradition fully emerged in the $20^{\text {th }}$ century. While India is commonly known for the establishment of agriculture, there is also a long history of hunting in the subcontinent. The Mohenjo-Daro peoples and the Harappas of Gujarat of the Indus Valley Civilization, the oldest 
documented civilizations in India created a settled lifestyle based on wheat and barley cultivation and recent research has shown that the Harappas of Gujarat collaborated with hunter-gatherers who resided near them. ${ }^{1}$ These hunters had tools presumably for the killing of game that ranged in shape from crescents and triangles along with various stone tools. Hunter-gatherers presumably coexisted with Harappans as they traded goods such as their stone tools as well as teak and other commodities of the forest to the agricultural peoples. This co-existence of tribal hunter-gatherers and settled persons became formalized by the Forest Act of 1878 which taxed the products of the forests such as honey and helped tribal hunter-gatherers obtain a form of currency and living while giving considerable revenues to the Raj. This study does not focus on hunting in the prehistoric period but begins with a summary of various hunting aspects of the Mughal and princely ruler periods. The study begins with the Mughal hunting because that is when records are available. From around $2500 \mathrm{BC}$ during the rise of the Indus valley civilization and onwards it can be shown that primitive hunters or shikaris were practicing hunting approaches that dated back to this era.

There are mainly three hunting traditions. One deals with formal hunting representing the Mughals and Mughal successors from the dawn of the Mughal era to the $20^{\text {th }}$ century. The second component of the Indian hunting tradition deals with hunting by shikaris or native hunters, tribals or villagers. The third hunting tradition involves the hunting styles of well-to-do Indians whose hunting practices reflect the epitome of the Anglo-Indian hunting style. Indians can roughly be categorized into three types of

\footnotetext{
${ }^{1}$ Gregory L Possehl, "Harappans and hunters: economic interaction and specialization in prehistoric India" in Eds. Kathleen D. Morrison and Laura L. Junker, Forager-Traders in South and Southeast Asia (Cambridge: Cambridge University Press, 2002), 70.
} 
hunters who collectively had different feelings towards hunting. While villagers hunted part-time or to protect their crops from ruin and therefore hunted for a practical purpose, they also at times hunted in order to display their prowess and worth over other villagers. The other two groups hunted for different reasons. Tribals hunted for subsistence primarily and hence their attitudes toward hunting are determined from the standpoint of their livelihood. Elite Indians hunted in order to engage in sport and display their manliness very similar to the reasons British male hunters chose to hunt. This study shows that the social background of a person is a good indicator of one's attitudes towards hunting and hence generalizations about Indian hunting should be avoided.

This study deconstructs the hunting experiences of Indian men and British men and women in colonial India by drawing upon a collection of hunting books, papers, and letters. These men and women called themselves Anglo-Indian. In this context, this dissertation uses the term Anglo-Indian to define a British resident of colonial India. Today however the term Anglo-Indian is used to refer to persons of mixed Indian and British descent. These include sources written by eminent sportsmen and sportswomen like Edward Baker and Isabel Savory as well as spectators like Fanny Eden. Hunting has been emphasized as a masculine and imperial enterprise, however, this research complicates this narrative by introducing female and Indian hunters, who presented a challenge to the fundamental tenets of the Raj. Most women who viewed hunts were mere spectators, however there were some women who actively engaged in the sport of hunting in companionship with their husbands, other males, or with shikaris or native hunters. Many women emphasized their disapproval of the murder of game and were thus 
precursors to the environmentalist movement of the $20^{\text {th }}$ century. This contrasts very much from male sporting narratives that emphasize the manliness, strength and courage of the hunter against his game. British women in India did not just view and participate in hunting of game birds typical in Britain such as partridges, pheasants and snipe but also in dangerous hunts like tiger hunting. My argument is that female hunters in India complicate the definition of femininity as they are not the frail or fragile subordinate women that most assume them to be. Female hunters also served as role models for Indians and it explains their place in the Empire as active imperialists who sought to control the Indian environment with their guns. This investigation enriches the previous literature because no scholar up to this date has focused on indigenous and female hunting primary sources. Furthermore, this dissertation adds Indian and female agency to the hunting narrative.

The dissertation examines the development of continuities and changes to hunting in British India by examining the works of various individuals: both subjects and colonizers in the Raj. Their views on hunting contributed to shifts not only in the practices, but also in the nature of hunting. One of the end goals of this dissertation is to show how colonial knowledge was incorporated into the Anglo-Indian hunting practice by examining the concerns and thoughts of hunters. Without the inclusion of hunters and the role they played both in establishing relations with Indians and in developing the conservationist ethos, our understanding of the study of British imperial environmental history remains imperfect and unfinished. By the early $20^{\text {th }}$ century there was increasing 
concern by the colonial state in India as well as the India Office in London about the possible decline of game, damage to agricultural crops, illicit hunting by poachers, the increasing use of high-velocity cordite rifles, and the threat of man-eating tigers. Alarms, doubts and divisions about potential declines in agricultural revenues and the extinction of endangered species also resounded both in the colonial state and the administrative, metropolitan governing body - the India Office.

\section{Literature Overview}

This dissertation discusses common narratives of hunting, however it also builds on important works in African, British and British Imperial, and Indian history. The major debates in African history that this study deals with concern the question of relations between the British and African tribal hunters. Edward Steinhart argues that the idea of the aristocratic hunt was created in Kenya amongst white settlers, while African hunters were systematically labeled as poachers. Edward Steinhart's Black Poachers, White Hunters: A social history of Hunting in Colonial Kenya is an important book that deals with this debate. ${ }^{2}$ Steinhart argues that African hunting techniques such as the use of poisoned arrows were perceived by white hunters as poaching since they did not use guns. The present study likewise examines the refined class associations of the British and indigenous tribal Indian hunters, many of whom used "poaching-like" methods of hunting. Some Indians used coconut plant fibers, nets, snares, and poison to capture

\footnotetext{
${ }^{2}$ Edward Steinhart, Black Poachers, White Hunters: A Social History of Hunting in Colonial Kenya (Athens: Ohio University Press, 2005), 101.
} 
animals, all of which was perceived as poaching by the British because guns were not used.

The next major debate to be examined is the connection between hunting and imperialism. William Storey's "Big Cats and Imperialism: Lion and Tiger Hunting in Kenya and Northern India, 1898-1930" offers a comparison of hunting in Kenya and India which links hunting with imperialism in his study of the sport. ${ }^{3}$ Storey's main argument is that hunting was an important arm of the British Empire as hunting in both the East African Protectorate and India was undertaken for both sport and imperial necessity. For example, in Africa, lions were shot to protect railway workers during the building of the Uganda railway. Animals were also shot during military expeditions for 'sport.' Storey also links hunting with the need to advance civilization, progress, and domination of the "land and labor" of both Kenya and Northern India. Civilization was associated with settled, fixed societies that were primarily agricultural. Wildlife was seen as a threat to this type of society as farmers and settlers cleared the land of wild game. Diseases like sleeping sickness and rinderpest could be transferred to domesticated animals like cattle from wild game and hence there was all the more of a fear of wild animals. Hunting for the British in Britain was associated with the aristocracy and their struggle to maintain upper-class values, whereas British settlers in the colonies hunted not only different animals but also for protection, sport and to further imperial goals.

The next debate in the history of hunting to be examined concerns the social

\footnotetext{
${ }^{3}$ W.K. Storey, "Big Cats and Imperialism: Lion and Tiger Hunting in Kenya and Northern India, 1898-1930," Journal of World History (1991): 138.
} 
conflicts and tensions involved in the sport. Emma Griffin's Blood Sport: Hunting in Britain since 1066 states that while the elite did hunt and felt it was their privilege, the lower orders also hunted by using their wit to capture animals. Griffin's argument is that "hunting has been a source of social conflict" throughout history. ${ }^{4}$ According to Griffin, it represented the struggle over mastery of land and nature and pinned the aristocrat against the poacher. E.P. Thompson makes a similar remark as he states how the Whigs instituted the Black Act of 1723 which implemented a capital offense of death for poaching hares or stealing deer. ${ }^{5}$ This was part of the ascendancy of the aristocracy and their increasing control over Parliament and land. The Enclosure Acts, or closing off of the common grazing lands in villages with fences can also be seen as part of this assault of common rights. As E. P Thompson discusses, part of the transition to a capitalist, market economy resulted in the disappearance of customs, which gave the poor certain rights and made the poor use their customary rights even more so in the form of the "sale of wives" or form of divorce during the corn riots. Hunting legislation was pitted against the "poacher" and other forms of communal customs. ${ }^{6}$ Roger Manning also emphasizes how hunting became associated with nobles as he argues that hunting served as a substitute for war. ${ }^{7}$ Poachers were increasingly tried in the courts in an effort to eradicate them and, in turn, placate the prestige of hunting as that of a gentlemanly sport. Tensions and alarms also

\footnotetext{
${ }^{4}$ Emma Griffin, Blood Sport: Hunting in Britain Since 1066 (New Haven: Yale University Press, 2007), 9.

${ }^{5}$ E.P. Thompson, Whigs and Hunters: The Origin of the Black Act (New York: Pantheon Books, 1975), 21-23.

${ }^{6}$ E.P. Thompson, Customs in Common: Studies in Traditional Popular Culture (London: New Presss, 1993), 179.

${ }^{7}$ Roger B. Manning, Hunting and Poachers: A Social History of Unlawful Hunting in England, 1485-1640 (Oxford: Clarendon Press, 1993), 36.
} 
resounded among British sportsmen in colonial India whose strong views on gentlemanly sport helped implement legislation that made the poacher pay fines and appear in court.

This work also situates itself in the debate on hunting, imperialism and gender studies. Joseph Sramek argues that hunting was both a masculine and imperial endeavor. ${ }^{8}$ Sramek's main argument is that the British symbolically sought to dominate the environment by hunting tigers during the 19th century. Sramek first explains how Britons in India were aware that the tiger was considered one of the most powerful animals by the Mughals and Indian princes and therefore tried to emulate the legacy of the Mughals. For example, Mountstuart Elphinstone, the governor-general of Bombay also noted that Akbar killed many tigers. As Sramek emphasizes, the "Edwardian spectacle of British royals $[\ldots]$ being photographed standing aside dead tiger carcasses depicted the staging of the successful conquest of Indian nature." This was crucial to establishing the British dominance of the environment. However, nature was not conquered by any means as this study shows how the environment was always a contested location by numerous actors from a variety of socio-economic and racial categories. The British were not alone in the objective of controlling the environment. Sramek's argument is narrowly focused mainly because he infers that British imperialists tried to dominate the environment by hunting tigers alone. Yet not all Britons hunted to control nature, others hunted simply for sport or protection purposes. Therefore, a more complex answer is necessary. Natasha Nongbri, for example, in "Elephant Hunting in Late $19^{\text {th }}$ Century North-East India, Mechanisms of

\footnotetext{
8 Joseph Sramek, “"Face Him Like a Briton': Tiger Hunting, Imperialism, and British Masculinity in Colonial India, 1800-1875," Victorian Studies Summer 2006: 665.

${ }^{9}$ Sramek, 659 .
} 
Control, Contestation and Local Reactions" shows how the colonial state hunted elephants through kheddah operations in Dacca, but also had some Indians issued licenses for the purposes of elephant hunting. ${ }^{10}$ Kheddah operations refer to the rounding up of wild elephants. Elephants were hunted not primarily for shooting and killing, but to train and use as beasts of burden so that they could assist with the hunting of other game.

What is more, hunting was not solely a masculine endeavor, as females hunted as well. One of the key issues that imperial gender historians have treated is the idea that activities which are regarded as masculine are often associated with females. Margaret Stroebel for example discusses how women were active imperialists, indirectly "crusading" for the Empire, a masculine entity. Mary Procida points out that many British women in India took on masculine roles. British women handled guns, ordered servants, and displayed their shooting marksmanship when their husbands were absent. ${ }^{11}$ The masculinity narrative that is most commonly associated with hunting is blurred. Hunting complicates gender roles and identities because women moved outside the traditional fold and did things that were seen as unconventional for their gender.

Shikar expeditions often defined British and Indian masculinities. Similarly, debates over masculinity were specific to a British hunter's interpretation of the stalk and hunt. Therefore, gender has to be analyzed alongside race. Associating a lower masculine status with an Indian hunter helped project an image of superiority to British

\footnotetext{
${ }^{10}$ Natasha Nongbri, "Elephant Hunting in Late $19^{\text {th }}$ Century North-East India Mechanisms of Control, Contestation and Local Reactions," Economic and Political Weekly, July 26, 2003: 3189.

${ }^{11}$ Mary Procida, Married to the Empire: Gender, Politics and Imperialism in India, 1883-1947 (Manchester: Manchester University Press, 2002), 150.
} 
male hunters which helped justify continued British rule in India. As Mrinalini Sinha shows in Colonial Masculinity: the 'manly Englishman' and the 'effeminate Bengali' in the late nineteenth century Bengali males were rendered effeminate by the British during the controversy over the Ilbert Bill, a bill which allowed Indians to serve as magistrates against British individuals. ${ }^{12}$ At the same time Anglo-Indians portrayed themselves as the only fit males to serve as magistrates. The feminization of Indian males was a constant in both British male and female hunting narratives. Relations between Indian and British females can also be ascertained in the hunting arena when analyzing race and gender. British women had a burden to uplift Indian women. ${ }^{13}$ Similarly, British female hunters believed they had a burden to uplift Indian male hunters and make them desist from poaching for the good of all animals.

The history of game preservation is another debate that is very much connected to the literature on hunting. Thomas Ofcansky makes important points about game preservation efforts in Kenya, Tanganiyika and Uganda. ${ }^{14}$ Ofcansky mentions that big game hunters were the first to set up Societies for the Preservation of wild game. These became Empire-wide societies that primarily focused on Africa, but also tried to initiate

\footnotetext{
12 Mrinalini Sinha, 'Colonial Masculinity: The 'Manly Englishman' and the 'Effeminate Bengali' in the Late Nineteenth Century” (Manchester: Manchester University Press, 1995), 45.

13 Antoinette Burton, Burdens of History: British Feminists, Indian Women and Imperial Culture, 1868-1915 (Chapel Hill, University of North Carolina Press, 1994), 5.

14 Thomas Ofcansky, Paradise Lost: A History of Game Preservation in East Africa (Morgantown: West Virginia Press, 2002), 10.
} 
directives for India. This ideal for preservation stood in distinct juxtaposition to the common colonial craze for hunting. The popular colonial perception was that some animals such as crocodiles and hyenas were considered "vermin" and could be easily shot by anyone. Similar notions were placed on man-eating tigers in India. Tigers however were more than simply vermin given their symbolic importance for pre-colonial Indian rulers as shown by Joseph Sramek. The tiger was viewed as the most formidable beast of the jungle and conquering it was a kingly display of power, the mantle of which was upheld by British imperialists. Hunters typically became advocates for preservation because of the un-natural declines caused by unchecked shooting as well as their efforts to follow the law. John MacKenzie's Empire of Nature similarly states that while British sportsmen engaged in the destruction of game in the Empire, there was a shift towards preservation by the $20^{\text {th }}$ century. ${ }^{15}$ This concern for wildlife preservation leads first to game preserves so elite hunters can hunt and then eventually to national parks wher hunting is not allowed. The "great white hunter" becomes the "great white photographer." The narrative concerning India follows a similar trajectory, except forestly plays a more cruticial role. Game protection was closely associated with the history of forestry reserves in India, unlike Africa. As Gregory Barton states in Empire Forestry and the Origins of Environmentalism Lord Dalhousie's Forest Charter of 1855 instituted a system of protected forest reserves. ${ }^{16}$ This environmental stewardship was an important

\footnotetext{
15 John MacKenzie, The Empire of Nature: Hunting, Conservation and British Imperialism (Manchester: Manchester University Press, 1988), 171.

${ }^{16}$ Gregory Barton, Empire Forestry and the Origins of Environmentalism (Cambridge: Cambridge University Press, 2002), 7, 52.
} 
precedent for the $R a j$ and marked the sense of ecological consciousness in the state apparatus. Forest guards were also used in order to curtail poaching, a mainstay of tribal hunters. Initially, game reserves catered to sportsmen, but later national parks during the 1930s were a mark of progress and advancement from the British Empire to the colonial peoples. Conservation occurred in the form of reserves that served as wildlife sanctuaries. The earliest reserves were operated by the forestry department and were located in Bengal. During independence, efforts of conservation would lead to Project Tiger which was launched in 1973 to save the almost extinct tiger population. Michael Lewis discusses the desire that ecologists and the WWF had to create tiger reserves to protect nature from human encroachment. ${ }^{17}$ Tiger reserves were introduced by the federal government of India in order to protect the tigers from increasing urbanization, agricultural encroachment, or human disturbances. Project Tiger does not reflect colonial efforts to create game reserves because tigers were often attacked due to their status as man-eaters. Indian nationalist leaders also did not share the same sentiments as the British who viewed tiger hunting as the biggest prize one could obtain in the jungles. Today, patrol camps are set up in order to curtail poaching activities. Lewis shows that there was an emphasis on large scale conservation projects in independent India largely due to the efforts of environmentally trained Indian ecologists. Conservation measures were sometimes unsuccessful. The wetlands at Bharatpur is a good example of failure since humans, cattle and wildlife could have coexisted peacefully with cattle actually

\footnotetext{
${ }^{17}$ Michael Lewis, Inventing Global Ecology: Tracking the Biodiversity Ideal in India, 1947-1997 (Athens: Ohio University Press, 2004), 166.
} 
increasing numbers of rare birds. Lewis argues that conservation efforts after independence were a break from the colonial period because of the growing influence of Amercan conservationists. My research shows that conservation efforts are in part a continuation of the legacies of British colonial practices, however they are also a product of American-trained Indian conservationists who took on the cloak of former British colonial hunters/conservationists.

This dissertation situates itself within the currents of colonial environmental history. As K. Sivaramakrishnan mentions in his article, environmentalism was not solely a product of colonial state officials, but the larger awareness of ecological issues was a product of the interaction between villagers, tribals, and others in the colonial state many of whom were struggling for dominance of the local forests. ${ }^{18}$ Thus, the flow of ideas between a wide array of colonial and imperial officials and non-officials produced the framework of environmental policies.

Lastly, this dissertation also seeks to contribute to the growing specialization of hunting within the environmental history of India, where the history of forest management issues dominate the literature. Environmental historians such as Richard Grove and Richard Drayton have focused on the imperial interaction with the Indian environment.

Circuits that connected colonies to other colonies and Britain to the colonies are also discussed through the Royal Botanic Gardens at Kew, which received seeds from all

\footnotetext{
${ }^{18}$ K. Sivaramakrishnan, "Science, Environment and Empire History: Comparative Perspectives from Forests in Colonial India," Environment and Empire 14 (2008), 42.
} 
over the world. ${ }^{19}$ Drayton effectively shows how the history of science can be combined with the history of imperialism. In doing so, he discusses how the history of science must not be relegated to European history. Drayton suggests that imperial expansion was fuelled by networks of botanists who had stations from Kew, Calcutta, Singapore and Trinidad and whose main goal was to control the resources of the world and at the same time conserve these plants. This contradictory dialectic is evident in the goals of hunters who tried to control big game while simultaneously preserving it as well, in order to continue hunting. Unlike previous histories that catalogue the process of political and economic domination, Drayton is singularly concerned with how scientific knowledge helped propagate imperial expansion and vice versa. These botanists in various stations around the Empire also created new plant species and therefore the idea of improvement was one of the main engines of change. British officials were already propogating imperial expansion by acquiring a knowledge of big and small game in India, just as they were acquiring knowledge of non-European plant species. Grove argues that environmental thought was built on pre-colonial institutions and indigenous knowledge from peripheral colonies. ${ }^{20}$ As Grove contends, colonial expansion in peripheral states like Madagascar and St. Helena opened the eyes of British officials and scientists, as well as hunters, who were keenly aware of possible extinctions of endangered species. Similar to hunting narratives, botanists collected various species

\footnotetext{
${ }^{19}$ Richard Drayton, Nature's Government: Science, Imperial Britain and the Improvement of the World (New Haven: Yale University Press, 2000), 108.

${ }^{20}$ Richard Grove, Green Imperialism: Colonial Expansion, Tropical Island Edens, and the Origins of Environmentalism, 1600-1860 (Cambridge: Cambridge University Press, 1995), 80.
} 
from Asia and Africa to introduce to botanical stations in Kew. The British also battled deforestation measures with regards to certain trees like pineaster. Replanting of trees in parts of India was largely due to fallen profits from teak planatations in Malabar.

It is important to note that this present study places the hunting and conservation methods throughout the $18^{\text {th }}$ to $20^{\text {th }}$ century in the context of wider trends in environmentalism. British hunting practices varied tremendously and were often destructive as well as environmentally sensitive at different times. Indian hunting practices were also quite destructive. This is quite a departure from Gadgil and Guha who argue that pre-colonial rulers' practices and attitudes were much more environmentally sensitive than the British. ${ }^{21}$

This present study situates itself in the historical context of John MacKenzie's seminal study on imperial hunting. John MacKenzie in Empire of Nature: Hunting, Conservation and British Imperialism has only one chapter on hunting in India; the bulk of his book focuses on hunting in Africa, yet he presents an effective overview of the hunting situation in British India. MacKenzie argues that "in the high noon of Empire hunting became a ritualised and occasionally spectacular display of white dominance. European world supremacy coincided with the peak of the hunting and shooting craze."22 This shooting craze is evident in the published memoirs, papers, and books of hunters in India. Furthermore, handbooks designed for the griffin or newcomer to India also listed

\footnotetext{
21 Ranajit Guha and Madhav Gadgil, This Fissured Land: An Ecological History of India (Berkeley: University of California Press, 1992), 26.

${ }^{22}$ MacKenzie, Empire of Nature, 7.
} 
the whereabouts of game to help facilitate men to become sportsmen. For example, Murray's Handbook for India, Burma and Ceylon stated that in Kalpi, a town near Calcutta, "Sport is abundant. Deer, wild boar, and a great variety of seabirds are found throughout the year. Tigers are to be met with in the jungle ; but tiger shooting, as practised here, is very dangerous. ${ }^{23}$ Similarly, the handbook goes on to highlight the top destinations of the British in India for hunting as Murray mentions that in the Lohab Valley, near Srinagar in Kashmir, is where black bears can be found. ${ }^{24}$ According to MacKenzie, hunting in Indian states became an obsession of British officials and residents. This study builds on his overview of hunting by providing an in-depth view on the history on hunting in India.

\section{Sources}

This study uses primary sources such as books, letters, archival papers and materials, and sources from Special Collections to examine British and Indian male hunters along with women who viewed hunts. In doing so, this dissertation analyzes these sources and reconstructs a narrative of their experiences while highlighting their thoughts. Personal accounts come from a wide variety of individuals in the Raj, including resident-planters, military officials, forest officials, policemen, civil servants, aristocrats/ dignitaries, women, Indian shikaris and Europeans and Americans visiting India for the purposes of shikar largely in the $20^{\text {th }}$ century. Forest officials and military officials are

\footnotetext{
${ }^{23}$ Murray's Handbook for Travellers in India, Burma and Ceylon $15^{\text {th }}$ edition (Calcutta: Thacker, Spink \& Co., 1938), 132.

${ }^{24}$ Ibid, 386.
} 
overrepresented in shikar books primarily because military officials often took leave simply to hunt and part of a forest official's job was to take care of the forests, and hunting was a large part of that equation. There are a sprinkling of sources from residentplanters and they tend to come from those in Assam and Bihar, where most of the plantations (typically tea) and factories (indigo) were located. Policemen in the $19^{\text {th }}$ and early $20^{\text {th }}$ century were also quite active as hunters in the districts where they worked. Much of the sources from policemen come from departmental heads located in Calcutta. Civil servants, as John MacKenzie notes, often wrote descriptions of their experiences in colonial India in the form of shikar books during the $19^{\text {th }}$ and $20^{\text {th }}$ centuries. A shikar book is essentially a book that focuses on hunting as its main focus or a substantial amount of the material in the book is related to hunting activities.

Some shikar books come from the same person who hunted both in India and in Africa and this has provided a great comparison for differences in their hunting styles over the course of their life. Hunting styles vary because of the difference in animals found in Africa. Native porters and caravans were usually relied upon for safari trips in East Africa. The "kill" was often distributed to the caravan to ensure a form of payment and continuance of travel. Deadly disease sometimes affected hunters and geographical information, native information, taxonomy, and sketches appear in hunting books. In many cases, certain tribes such as the Maasai even asked the British to hunt animals that disturbed their herds. Col. E.D. Miller is an example. ${ }^{25} \mathrm{~A}$ few shikar books also contrast experiences with hunting in Africa, which helps explain the development of the

${ }^{25}$ Lieut. E.D. Miller, Fifty Years of Sport (London: Hurst and Blackett, Ltd., 1925), 221. 
gentleman hunter by the $20^{\text {th }}$ century. Hunting in Africa typically was part of a safari expedition.

While some hunting books are official in that they are published by those who worked for the Raj, these published accounts are supplemented with official sources from the British Library and personal documents from the Centre for South Asian Studies in Cambridge, UK so that the dissertation is not biased towards any one view, but balanced with a mix of official and non-official papers. Sources from the British Library generally comprise of questions on game deterioration and damage to agriculture, game laws, hunting card records, Tent Club records, and private hunting papers. Sources from the Center for South Asian Studies are comprised of personal papers, letters and memoirs which detail hunting experiences, often without the additional spectacle and exaggeration that published books generally contain. Feelings tend to be more sincere since they are addressed to a relative or close friend. This provides a good contrast and complements published accounts that are often trying to sell a story.

Sources for the chapter on women include books written by women who resided in British India, either temporarily or long-term. Travel writing sometimes devoted quite a bit of space towards hunting or did not depending on the interests of her companions and the author itself. In addition to published books written on one's experiences in colonial India, memoirs and letters from various archival sources and Special Collections were also used to construct a narrative of women's hunting experiences.

Indian hunters' accounts are primarily divided into four categories of sources: Mughal hunting, nawabi/maharaja hunting, educated hunters and tribal shikaris. A major 
source of hunting information about the Mughals comes from Mughal records such as the Babarnama, Jahangirnama and Ain-i-Akbari. These are official accounts of the exploits of Mughal emperors usually recorded by the court historian or royal librarian. Accounts of hunting experiences are littered throughout the entire volume over the course of each emperor's reign. These accounts usually emphasize natural history, the methods of the hunt, the hunting "bags" that were obtained, and the great masculine feats of the emperor relating to hunts. Hunting was a leisure sport for the Mughals. As Muslims, they typically had no moral restrictions against hunting, however they did display the regal trait of compassion when they ordered an end to the bloodshed of hunting, which was at their personal discretion. The Mughals were regal hunters and their traditions were followed by princely rulers who were not Muslims. Therefore, Mughal traditions became Indian traditions. The Mughals, like the British, reveled in the great numbers of game that were under their swords or gun-points as it displayed their symbolic mastery over their adopted Hindustan or India. The excessively huge "bags" of game that they obtained during these hunts represented a lack of an environmental conscience, and was seen by the British as an example of 'Oriental despotism.'

The next section on Indian hunting focuses on sources from maharajahs as well as nawabs or princely successors to the Mughals. The sources in this section are mainly comprised of books by nawabs and maharajas. The papers of Shahu Chhatrapati, the Maharaja of Kohlapur contain various bits of information regarding shikar. The maharajahs were instrumental in forging the regal hunt and lavishly expressed hospitality to various European and British dignitaries by providing them shikar in their private 
preserves in the princely states as well as feasts and amusements in the form of dancing girls at their court palaces. Letters detail how shikaris served as gifts to other royals, which show how networks of royalty prized shikar gifts. David Cannadine's argument that British and non-European societies had similar notions of class fits in well with the importance of gifts between monarchs or persons of high stature. Personal books on hunting by maharajas such as Thirty-seven Years of big game shooting in Cooch Behar, the Duars and Assam, A rough diary by Nripendra Narayana Bhupa, the Maharajah of Cooch Behar, and Bana jangala sikar katha by Bhupendra Chandra Sinha, Maharaja of Susanga, also offer great insights into the relationships of maharajas and their respective shikaris. ${ }^{26}{ }^{27}$ The bond between shikaris and maharajas was quite strong and represented an unusual relationship between the higher and lower orders. Such sources also display the maharajas' unpretentiousness and their oneness with their shikaris while in the jungles. While hunting books were typically written in a maharajah's native tongue, there are sources written in Sanskrit, the language of Brahmin priests such as Syankika s'astra; or a book on hawking, by Rudra Deva, the Raja of Kumaon. ${ }^{28}$

Hunting books were also written by educated Indians. They are written in a variety of different languages including Bengal, Malayalam, Urdu, and Hindi. Sources written in Bengalis tended to come from hunters residing in Bengal or men who were Bengalis by ethnicity. These men were Hindus. Sources written in Hindi were authored

\footnotetext{
${ }^{26}$ Maharajah of Cooch Behar Nripendra Narayana Bhupa, Thirty-seven years of big game shooting in Cooch Behar, the Duars and Assam, A rough diary (London: R. Ward, 1908), 25.

${ }^{27}$ Bhupendra Chandra Sinha, Bana jangala o sikara katha (Bombai: Oriyenta Lammyansa, 1970), 15.

${ }^{28}$ Raja of Kumaon Rudra Deva, Syanika sastra: or a book on hawking (Calcutta: Royal Asiatic Society, 1910), 20.
} 
by Indians from various locations in North India. They are generally Hindu hunters.

Sources written in Urdu are typically from Muslim hunters who resettled in Pakistan after partition. Sources in Malayalam are written by men who are ethnically Keralites. Malayalee sources are the only ones that we have from hunting in South India. Typically, the language the hunter-author used correlated to the locality where the hunter resided and hunted. For example, the source written in Malayalam involved hunting in Kerala and the Malabar coast. There are also hunting books written in English by various welleducated authors such as Sindh: Ways and Days: Shikar and Other Memories by Pir Ali Muhammad Rashdi, Call of the Tiger by Minuchihr Mohammed Ismael, Purnea: a shikar land by Kirtyanad Sinha, Shikar by Jamshed Butt and Shikar Tales by the Barrel by Jit Roy. ${ }^{29}$

Tribal shikaris and part-time villager-hunter's accounts come from books written by British male and female hunters where specific passages are devoted to various tribals. Villagers who took up arms against animals have various accounts recorded in British shikar books mostly in the $19^{\text {th }}$ and $20^{\text {th }}$ centuries. Most shikar books dedicate the majority of their time to the author's individual feats, while shikaris feats also sometimes secondarily appear in the narrative. A few sportsmen such as Arthur Brinkman relayed the abilities of villagers to fend for themselves against wild game while ensuring a nice

\footnotetext{
${ }^{29}$ Pir Ali Mohammed Rashdi, Sindh: Ways and Days: Shikar and other Memories (NY: Oxford University Press, 2003), 100.

Col. -Lieut. M. M. Ismael, Call of the Tiger (London: Faber \& Faber, 1964), 25.

Kirtyanand Sinha, Purnea: a shikar-land (Calcutta: Thacker, Spink, \& Co., 1919), 40.

Jamshed Butt, Shikar (London: Robert Hale, 1968), 90.

Jit Roy, Shikar Tales by the Barrel (Bombay: Pearl Publications, 1968), 20.
} 
gourmet meal as well. Most villagers in Kashmir tended to be Muslim and consequently had no reservations against eating deer meat, provided it was halal, meaning its throat was slit prior to consumption. In Brickman's shikar book that primarily focuses on Kashmir he writes that barasingha or deer with twelve horns are frequently hunted by Indian women. He takes pains to emphasize that they "catch" barasingha instead of hunt them presumably because they do not use the correct etiquette. This is one of the only records we have pertaining to Indian village women as he states that "even the women catch them." ${ }^{.30}$ Another record of Indian women and their method of hunting comes from W.W. Baillie, a British female hunter. Baillie also emphasizes how Bhil women hunted tendwa or panther. In one case, a tribal woman started a fire for the panther to come out of the cave. ${ }^{31}$ We do not know whether she ended up killing the panther or not, but she was certainly present in the jungle and actively participated in trying to kill the panther. The lack of records of hunting by Indian women, both villagers and tribals, is one of the reasons I have decided to omit them from this study even though as these source prove, they did hunt meek animals like barasingha as well as dangerous game.

This dissertation covers hunting over much of colonial India, but by no means all of the subcontinent. North Indian sources dominate the narrative of this dissertation, yet there are a few substantial sources from South India by female authors, British male sportsmen, and Indian sportsmen who hunted in such places as the Nilgiris. Hunting in

\footnotetext{
${ }^{30}$ Arthur Brinckman, Rifle in Cashmere: a narrative of shooting expeditions in Ladak, Cashmere, Punjaub, etc., with advice on traveling, shooting and stalking: to which are added notes on army reform and Indian politics (London: Smith, Elder, Co., 1862), 82.

${ }^{31}$ Mrs. W.W. Baillie, Days and Nights of Shikar (London: J. Lane \& Co., 1921), 10.
} 
North India chiefly occurred in Bengal, Bihar, Assam, Burma, Kashmir, Ladakh, Nepal, and Tibet. Hunters also hunted game in Central India and the Punjab, though on a lesser scale.

This dissertation covers a wide variety of animals hunted. Most hunting books on shikar by Indian hunters emphasized the hunting of tigers, especially man-eating tigers. Maharaja hunting books typically involved tigers as well, although a variety of smallgame shooting and various references to hawking are also discussed. British hunting books offer a wide array of animals that are hunted including tigers/tigresses, wild boars (pigsticking), partridges, bears, tahr (goat), lions, panthers, sambar(deer), barasingha, ibex, pheasant, snipe, quail, ducks, hog-deer, elephants, black buck, cranes, rhinoceros, peacock, gharial (crocodile), barking deer, nilgai (blue bull), chital (spotted deer), gaur (bison) thiamin (deer) and markhor (sheep).

\section{Methodology}

Imperial historians such as Cain and Hopkins looked at the empire from London's perspective. Generally, imperial proconsulars who formulated imperial policies were the subjects of their analyses. From the perspectives of an earlier generation of imperial historians, Britain defined the Empire. They were not concerned with the work of nationalist historians who sought to define the colonial period through the perspectives of Africans or Indians. The study of elite colonial persons, like imperial proconsulars generally meant that view points were quite limited to those on the top of the administrative social ladder. It also marginalized colonial subjects to the realm of third- 
world nationalist history. The idea of imperial networks did not exist in the older imperial historiography. The insularity of the earlier imperial history led to the construction of a new imperial history school. This new approach emphasizes the role of colonial subjects in addition to the colonizers and adds to the literature of new imperial history. New Imperial historians seek to integrate both nationalist and imperial histories through a transnational framework. This new construction helps historians to study imperial lives and subjects in a transnational and comparative context by connecting metropole to colony and colony to other colonies. This is the reason that the current study has focused on hunting both in Britain and in British India, while occasionally referencing Africa. Individuals who took up imperial careers often lived half their lives outside Britain. The physical separation from Britain meant that certain new customs were created, while old leisure activities were re-suited to the new terrain. For example, instead of fox hunting, colonial administrators hunted for tigers or enjoyed pig-sticking. Company officials sent their children for schooling in Britain often living solitary existences thereby having significant amounts of time for leisure. Therefore, their British identities were in a state of constant flux and they melded traditions from the subject peoples into their own identities. Thus, one of the key dimensions of Empire revolves around the question of identity that these colonial persons faced and the eventual development of an Anglo-Indian identity. New Imperial historians using a revisionist approach to history seek to present the complexities of the individual. In doing so, they often challenge stereotypical identities associated with British imperialists. New identities were formed in the colonies in direct opposition to British officials, the natives, and the 
environment. The forging of colonial subject identities in relation to hunting and the development of Anglo-Indian identity are major themes discussed in this present study. This work emphasizes the complexities of trans-national identities and like new imperial historians breaks down the dichotomy between the identities associated with the colonizers and the colonized to show how colonial individuals developed their own sense of self. It can also be said that Indian elites who engaged in hunting developed their own hybrid identities as well.

\section{Overview of the chapters}

There are seven main chapters in this study that are divided into specific time periods. Chapter One introduces the reader to hunting in Britain from the $18^{\text {th }}$ to $20^{\text {th }}$ centuries. Hunting in Britain merely provides background information to set the stage for the reader. Its main purpose is to emphasize the connections between the metropole and the colony prior to crown rule in 1857 , but also for comparative purposes to establish the point that hunting was not simply the importing of ready made practices and traditions from Britain, but an amalgamation of British and Indian practices. The development of the Anglo-Indian hunting tradition began during the $18^{\text {th }}$ century with the British encounter with Indian methods of hunting. British etiquette and styles of hunting were later reintroduced to India by the turn of the century in the form of sporting books and influences of Britain's great sportsmen's manuals and books. The first chapter focuses on hunting in Britain in the $19^{\text {th }}$ and $20^{\text {th }}$ centuries. The second chapter draws upon the 
history of hunting in precolonial India thereby establishing how important hunting was as part of the lifestyle of certain Indians.

The subsequent chapters focus on India under the $R a j$ and are divided into specific periods of time and are organized according to the sources. The third chapter is on hunting by British men in colonial India during the $19^{\text {th }}$ century and discusses the heyday of shikar. The $19^{\text {th }}$ century chapter explains the importance of hunting in India and presents an overview of hunting at its zenith under the $R a j$. The chapter also has a section on how the British adapted to Indian ways of hunting and the sorts of rules and mores they brought to the activity of hunting. The chapter also focuses on the ways that the British tried to distance themselves from Indian hunters, while at the same time relying on them in many ways. It also focuses on how the British worked with princely Indian hunters (maharajas) and elite Indians and the lower subaltern groups for the purposes of the sport.

Chapter 4 examines British hunting in colonial India during the $20^{\text {th }}$ century, which marks the distinct differentiation of British hunters from their Indian subordinates. The $20^{\text {th }}$ century also sees the rise of British hunters who viewed themselves as a separate refined entity and, in turn, denigrated Indian hunters as poachers. Indian village men were not perceived to be trustworthy especially when they had firearms in their possession mainly because they were prone to excessive, impulsive action. The popular novel Justice by Alice Perrin, an Anglo-Indian writer written in the $20^{\text {th }}$ century presents a fictional example of the point. She writes of one village protagonist who has a permit for a gun to "protect [his] crop [s] from the deer and wild pigs" but instead he used his gun to attempt 
to kill another village man who fell in love with his second, younger wife/helper. ${ }^{32}$ The chapter also traces the rise of the regal hunt during the viceroyalty of Lord Curzon and also marks the moment when the British honed in the mantle of the maharajas as the British become the new hospitable rulers who invite Europeans and Americans to hunt the game of the subcontinent at their expense or the expense of their collaborators, the princely rulers.

Chapter 5 focuses largely on Indian hunting in the $20^{\text {th }}$ century, however it does provide an overview of hunting by princely successors, who retained control of their kingdoms even with crown rule. There is no chapter on Indian hunting in the $19^{\text {th }}$ century because there are no records of shikar books authored by Indians during this period of time. While we know that tribals did engage in hunting during the $19^{\text {th }}$ century, there are minimal references to them by British authors and the tribals themselves have not left any written records of their hunting experiences. The largest section focuses on educated Indians, many of them Bengalis, who took up hunting for sport following the model of the British and discusses the main methods of subaltern hunting by tribals and villagers.

The sixth chapter examines women and attempts to deconstruct the fragmented narrative of the female voice in regards to hunting in India. References to hunting are present in the writings of British women, whether as spectators or actual participants to the sport. Recreational and regal hunting (those typically associated with maharajas) provided women with a sense of excitement and adventure in their otherwise monotonous lives in British India. Hunting also offered women the opportunity to serve as imperialists

\footnotetext{
${ }^{32}$ Alice Perrin, Justice in ed. Saros Cowasjee Oxford Anthology of Raj Stories (Delhi: Oxford University Press, 1998), 158.
} 
as they commanded their own shikaris and servants. Female hunters also inspired awe in Indian villagers and possibly even their own shikaris for it was uncommon and untraditional for Indian women to hunt and such behavior served as yet another justification for the British to rightly continue ruling India because of the superiority of British females who possessed these masculine undertones. British females also differentiated themselves from Indian hunters in the late $19^{\text {th }}$ and $20^{\text {th }}$ centuries, similar to British males. Some women were staunchly opposed to hunting and expressed their fears and emotions against the activity and did not accept the craze for shooting that John Mackenzie states surrounded Anglo-Indians. This chapter also brings to light the fact that British women in India did not just order servants or stay at home, but were active participants in hunting events and handled guns, whether for recreational purposes or to protect themselves against dangerous game such as leopards or elephants. This chapter highlights a new type of feminism which was not focused on charity, education or introducing hygiene and etiquette to Indians but was focused instead on proving equal status with male hunters in the hunting arena in the $19^{\text {th }}$ and $20^{\text {th }}$ centuries.

As chapter seven shows, the Anglo-Indian hunting practice and style was crystallized in the $20^{\text {th }}$ century with the rise of game legislation, licenses, and game laws as well as a change in the character of British sportsmen who emphasized restraint and were imbued with a new conservationist ethos. The most important issue discussed in this chapter is the establishment of the Anglo-Indian amalgamated hunting style, which underwent significant change with the implementation of laws, licenses, and a sense of restraint. The conservationist ethos was also prevalent among educated Indian hunters as 
well as part of the emotions of the female hunters and some princely rulers, even before the $20^{\text {th }}$ century. Comparing and contrasting the hunting laws of Britain and the rise of hunting laws in colonial India in the $20^{\text {th }}$ century will show how the imperial government tried to reconstruct a distinctively English model for conservation in an effort to cut out poachers from the hunting equation, quite similar to England's struggle with poachers in the $17^{\text {th }}$ and $18^{\text {th }}$ centuries. In many respects the hybrid tradition of the amalgation of British and Indian traditions gave way to a more Anglocentric one in the $20^{\text {th }}$ century as British hunters tried to differentiate themselves from Indian hunters. Hunting etiquette and conservation laws and regulation was more Anglicized than Indian.

The ideology of restraint was marked in some sportsmen's books even in the $19^{\text {th }}$ century. A good example is Sir W. H. Sleeman who served as a Major-General and administrator of Narsinghpur District and as Commissioner for the Suppression of Thuggee and Dacoity, for which is he quite famous. Sleeman explicitly restrained himself from excessive shooting, which was in contrast to Oriental excess and "despotism." W. H. Sleeman writes that in Datiya, in present Madhya Pradesh, he went to "shoot and hunt in the Raja's large preserve, and with the humane and determined resolution of killing no more game than our camp would be likely to eat ; for we were told that the deer and wild hogs were so very numerous that we might shoot just as many as we pleased." ${ }^{\prime 3}$ Even though he had the ability to kill more game since the maharaja offered him the chance to shoot how many he pleased, he did not in fact slaughter larger numbers of game for the sake of sport. It was a common occurrence for Rajas to be more

\footnotetext{
${ }^{33}$ Sir W.H. Sleeman, Rambles and Recollections of an Indian Official (Karachi: Oxford University Press, 1844), 235-236.
} 
than hospitable to their British guests as they were usually disinclined to think of the ramifications of their words.

The conclusion will wrap up by discussing the decline of hunting in the 20th century and will touch on hunting and conservation issues in post-colonial India. It focuses on post-colonial hunters like Kesri Singh, Col. Jaipal Singh, Sher Jung, and Biswanath Bose. British hunters such as Jim Corbett who continued to hunt after the transfer of power in 1947 will also be discussed in an effort to trace the legacies that Anglo-Indian hunters established during British rule in the early part of the $20^{\text {th }}$ century. The emphasis on conservation and efforts such as the Project Tiger scheme will also be surveyed to explore the furtherance of the goals that began by British conservationistshunters and the late colonial state. 


\section{Chapter 1: Hunting in Britain- Eighteenth to Twentieth centuries}

This chapter surveys the development of hunting in Britain from the eighteenth to the twentieth centuries in an effort to differentiate it from hunting in colonial India. It focuses on how hunting became an elite sport and a sense of nascent ecological awareness and etiquette developed. Hunting in Britain in the $19^{\text {th }}$ and $20^{\text {th }}$ centuries basically continue this pattern resulting in the development of a conservationist ethos. By the $19^{\text {th }}$ century, even though hunting was considered a manly sport, women become involved as observers and hunters. Elite hunting developed traditions of condescension and hostility toward working-class hunting and to poachers.

Hunting has been a long established tradition in Britain. Evidence of hunting can be found in the pre-Roman period on Celtic crosses in Scotland. ${ }^{34}$ During the medieval period, evidence of hunting can also be viewed from the Devonshire Hunting Tapestries as well as various treatises written on hunting by aristocratic men. Popular hunting sports included otter hunting, deer driving, fox hunting, hare hunting, and pheasant and grouse shooting. Fox hunting became particularly prominent during the 19th century. Hunting in Britain was often carried out on horseback with hounds. There were however instances of shooting on foot. Organized hunting meets were usually spread by word of mouth, however by the early 20 th century they were almost always publicized. The 19th century was marked by numerous published accounts of hunting experiences. Paintings or drawings often accompanied stories of the chase and

\footnotetext{
${ }^{34}$ John MacKenzie, The Empire of Nature: hunting, conservation, and British imperialism (Manchester: Manchester University Press, 1995), 9.
} 
helped draw the readers into the excitement presented by the British 'Nimrod,' a biblical reference to a mighty hunter. Nimrod was a pseudonym that many hunters took up and published their hunting memoirs in an anonymous manner.

\section{Hunting in the early modern era}

Hunting in Britain during the late $17^{\text {th }}$ and $18^{\text {th }}$ centuries was primarily limited to gentlemen. Hunting in the early modern era was an elite sport and this phenomenon was replicated well into the $18^{\text {th }}$ and $19^{\text {th }}$ centuries. Marcia Vale states that hunting became an elite sport in this period. She writes that "the exclusive nature of many forms of hunting must have recommended the sport to many gentlemen as a badge of their class. ${ }^{35}$ The mark of the gentleman was found during the Elizabethan and Jacobean eras. The Game Act of 1671 also legally restricted the hunting of certain game like partridges, pheasants, hares and red grouse to those who earned more than a hundred pounds per year, which essentially curtailed hunting of winged game to the elite. Daniel C. Beaver's Hunting and the Politics of Violence before the English Civil War emphasizes how hunting became honorable and fashionable with nobles through 'ritualized violence' against animals during the late sixteenth and early seventeenth centuries. ${ }^{36}$

Emma Griffin, another authority on hunting in England states that while the elite did hunt and felt it was their privilege, the lower orders hunted as well by using their wit to capture an animal. Griffin's argument is that throughout British history "hunting has

\footnotetext{
${ }^{35}$ Marcia Vale, The Gentleman's Recreations: accomplishments and pastimes of the English gentleman, 1580-1630 (Cambridge: D. S. Brewer, 1977), 28.

${ }^{36}$ Daniel Beaver, Hunting and the Politics of Violence before the English Civil War (New York: Cambridge University Press, 2008), 2-3.
} 
been a source of social conflict." ${ }^{37}$ According to Griffin, it represented the struggle over mastery of land and nature and aristocrat versus poacher. E.P. Thompson makes a similar remark as he states how the Whigs instituted the Black Act of 1723 which implemented a capital offense of death for poaching hares or stealing deer. Hunting and by extension wild game now came into the domain of the Whigs. The Whigs were a political party that formed during the reign of Charles II who represented the interests of the aristocracy and were typically anti-French in foreign policy. These men tried to retain their rights to the common lands of the Windsor and the Hampshire Forests. Thompson shed new light on this conflict as he analyzed it through a Marxist interpretation. By contrast, the lack of social conflict in India was a great enticement for British hunters, who dove right into the opportunities to hunt. During the $17^{\text {th }}$ and $18^{\text {th }}$ centuries, the landed classes asserted more authority over trade, village rights, and hunting, which resulted in more hunting conflicts. These conflicts were simultaneous with and linked to the landowners' extension of control over the open field system through the Enclosure Movement where common lands were closed off to villagers. Thus game and forestry laws along with the regulation of hunting can be seen as part of the landed elite's attempt to control the land and its resources, much like the Enclosure Movement. The rise of hunting as an elite tradition reflected the rise of the landed classes as the ruling class in Britain through the ascendancy of Parliament and constitutional government over absolutism.

Roger B. Manning's work also emphasizes how hunting became associated with nobles. Manning argues that hunting served as a substitute for war from roughly 1485 to

\footnotetext{
${ }^{37}$ Emma Griffin, Blood Sport: Hunting in Britain Since 1066 (New Haven: Yale University Press, 2007), 9.
} 
1640. ${ }^{38}$ Poachers were increasingly tried in the courts in an effort to eradicate them and enhance the prestige of hunting as that of a gentlemanly sport. One of his main contributions is that he shows that there are a multitude of reasons why hunters poached. Some may have poached for game for the table, others for violent purposes, some to extend the laws of the forest, some with a gentleman's encouragement, or for the purposes of getting back at another gentleman. The complexity of the reasons for hunting is one of the strong points of his work. Manning's work also emphasizes the competing reasons that the British hunted game. For example some hunted out of boredom, others because of opportunities to become sportsmen, and still others out of nostalgic feelings of returning to a country life and because of the "bounty" of game.

\section{Hunting as an Elite Sport}

As Martia Vale has suggested, hunting was an elite sport in Britain. Clearly, this applied to royal and elite households. Parts of the forests were also strictly royal domain during the $17^{\text {th }}$ century and this further demarcate royal privilege from other hunters. Modern British hunting has aristocratic traces mainly because only landowners had horses to hunt game, even though nearly all Anglo-Saxon men were in possession of hounds. ${ }^{39}$ Discontent marked relations between poachers and the monarch. King James I's proclamation in 1609 states how gentlemen are not able to "reforme the corrupt

\footnotetext{
${ }^{38}$ Roger B. Manning, Hunters and Poachers: A Social and Cultural History of Unlawful Hunting in England, 1485-1640, (Oxford: Clarendon Press, 1993), 194.

${ }^{39}$ Thomas, Richard. The Politics of Hunting. (Aldershot, Eng.: Gower, 1983), 13.
} 
natures and insolent dispositions of some of the baser sort" when referring to poachers. ${ }^{40}$ This source of discontent would mirror future relations between the monarchy coupled with the aristocracy and other elites and poachers.

Despite the fact that hunting was associated with the privileged classes, as Marcia Vale and Emma Griffin state, open access to hunting continued for those who had the wit to capture their prey. In the $16^{\text {th }}$ and $17^{\text {th }}$ centuries, rabbits were hunted by gentlemen and the poorer classes. ${ }^{41}$ These treatises commonly taught potential hunters about the nature of their quarry, the environment in which the quarry is located, how to breed and take care of hounds, and provided an overview of standard techniques used to kill the target animal. Hunting treatises followed game regulations as well. For example, in the 1671 Game Act it restricted hunting of partridges, pheasants, hares and red grouse to the aristocracy and those who earned over a 100 pounds a year. Hunting treatises evolved by the $19^{\text {th }}$ century into both publications in outdoor magazines to published books on hunting by gamekeepers, illustrious hunters, and masters of foxhounds.

The royal family were strong patrons of hunting as a sport in Britain. Albert Edward, the Prince of Wales is described by a man writing under the pseudonym of Sabratache as "unquestionably extremely keen" and hunted with the esteemed ancient West Norfork pack of hounds. ${ }^{42}$ It is not clear when this occurred. Even though some monarchs did not personally hunt, the Victorian and Edwardian monarchies were actively

\footnotetext{
40 Ibid, 30.

41 Ibid, 33.

42 "Sabretache," Monarchy and the Chase (London: Eyre and Spottiswoode, 1948), 138.
} 
involved in preservation for the hunt. Queen Victoria, for example, regularly visited the Ascot kennels according to the huntsman Frank Goodhall. ${ }^{43}$ Similarly, the huntsman, Charles Davis, served the royal Buckhounds under George III, while his father served the King's Harriers. In 1728, carted deer were hunted by the royal packs at Windsor house. ${ }^{44}$ The royals had hunted deer in early modern and even Norman times.

By the Victorian and Edwardian eras, the new city rich began to hunt and "new money" became intertwined into the hunting scene. It was no longer only the landed gentry who indulged in the pastimes of hunting. For example, Sir Bache Cunard was the grandson of a shipping line magnate. With the money he acquired from business profits, he bought in 1881 an estate near Leistershire and Rutland along with the Billesden hounds and became an avid sportsman..$^{45}$

Just as the maharajas sponsored the hunt in India, Britain's aristocracy typically were patrons for fox hunters. The Duke of Wellington provided a large subscription to the Vine Hunt in Strathsfieldsaye estate where foxes were hunted. The Duke of Buccleuch was also an avid fox hunter. His countryside was filled with foxes. The writer who wrote under the pseudonym of Nimrod states that the Duke of Buccleuch killed at least fifty foxes every year with his hounds in the Dalkeith and Kelso areas. Even though his hounds hunted down so many foxes, he tried to give the foxes every chance they could to escape to level the playing field. Nimrod writes that "He draws the majority of

\footnotetext{
43 "Sabretache," Monarchy and the Chase (London: Eyre and Spottiswoode, 1948), 130.

${ }^{44}$ Edward William Dirom Cuming, British sport past and present (London: Hodder and Stoughton, 1909), 39.

${ }^{45}$ Ibid, 274.
} 
his covers down wind, thus preventing the possibility of his foxes being caught napping, as too many are, when drawn up wind. This is also liberal conduct in a huntsman, inasmuch as he gives his fox plenty of notice to get away, and consequently to bring his hounds to their noses sooner than if they went off close at his brush."46 Not overpowering animals in a hurried frenzy resulted in a sense of restraint and helped emphasize the sportsmanship skills of the hunter.

Hunters in the $20^{\text {th }}$ century also gave accounts of the various packs they had the pleasure of hunting with. These hounds had been carefully bred from a distinct pedigree and were thoroughbred champions. It was a privilege to hunt with such packs. Sir Claude Champion De Crespigny writes that he hunted with the following packs: "Tedworth, Luttrell, South, and West Wilts, Essex, Chiddingfold, Lord Leconfield's, Lord Radnor', New Forest, Lord Portman's, Vine, H.H. and Hursley ; and also with two packs of staghounds, namely, the Devon and Somerset, and the New Forest, the master of which was Sir Reginald Graham, the son of that fine old sportsman Sir Bellingham Graham [...]and with Lord Pembroke's, and Mr. Raikes’s harriers."47 When Crespigny was not serving the Irish militia in the late 1870s, he was in Southeast England fox hunting almost five days a week with the aforementioned distinguished packs.

\section{Hunting as a Sport in Modern Britain}

\footnotetext{
46 Nimrod, “Master of Hounds,” New Sporting Magazine 3: 17 (1842: May), 290.

47 Sir Claude de Champion Cresigny, Forty years of a sportsman's life: with two additional chapters covering the period 1910-1924 (London: Mills and Boon, Ltd., 1925), 61.
} 
Hunting, along with other competitive sports reached its peak during the mid-19 th century after the Crimean War and the unification and ascendance of Germany as a great power, which heightened the need for young Britons to display their competitive edge. Social Darwinism also drove competition and the need for manly sport. The idea of "the survival of the fittest" pushed Britons to competition in the sports arena and that seeped into the hunting domain as hunting served as a perfect arena for men to demonstrate their aggressive and competitive capabilities. Herbert Spencer similarly stated that "the contests of commerce are in part determined by the bodily endurance of the producers" thereby linking the free market and capitalism to the strength of a man's body in terms of his ability to win a game. ${ }^{48}$ Most of all sport was reinforced by the public school ethos that championed the aforementioned for its inculcation of team spirit, fair play, and healthy effects on the body. The old adage that "All work and no play makes Jack a dull boy' held very true for England as men took great pains to ensure they would not be dull boys.

Honor was exceedingly important for hunting as a sport in Britain. As Charles Kingsley urged young British males to "carry into [games] the principles of honour and religion," the notion of honor spread to field sports. ${ }^{49} \mathrm{In}$ terms of religion, righteousness was coupled with restriction and this is emphasized throughout Mosaic law. The biblical reference in Deuteronomy states that the taking of young animals is permissible, but the dam or mother must go free. This is an example of restriction in the

\footnotetext{
48 Peter Bailey, Leisure and class in Victorian England: rational recreation and the contest for control, 1830-1885 (London: Routledge \& K. Paul, 1978), 135.

${ }^{49}$ Bailey, Leisure and class in Victorian England, 84.
} 
Bible that helped lead to the foundation of the British need for restraint in the hunting domain. Similarly, in the Book of Genesis, Adam and Eve have full dominion over the beasts of the earth. The taking of game thus also influenced the British tradition of hunting. This constant tension between the taking of game balanced with righteousness and restraint was quite evident in England. Parsons, reverends and other clergymen usually participated in hunting activities in Britain, whereas they typically did not in India. de Crespigny had hunted with distinguished sportsmen/Reverends such as W. Awdry of Ludgershall, who even possessed a pack of beagles.

While hunting is commonly associated with the aristocracy, in the country, hunting was undertaken by all who were included in the hunt by the patronage of the Duke or nobleman who owned the hounds. Men of good character, regardless of their lowly birth, were included in the hunt. For example, a man named Adam Sherwood, who by profession was a sweeper of chimneys, was a good foxhunter and Elliott, the foxhunter even describes him as a "great authority." ${ }^{50}$ Despite not being dressed in hunting attire, he used to tell the huntsman George Beers what he should have done while hunting. The Ground Game Act of 1880 was a liberal measure which allowed tenants the right to kills rabbits and hares, although they were not given the right to kill game birds.

Just as in India, the beauty of the hunting atmosphere was praised by hunters and shooters alike and helped sportsmen spend time in the wilderness and appreciate nature. Sir William Beach Thomas writes "What a portfolio of gorgeous English

${ }^{50}$ John Malsbury Kirby Elliott, Fifty Years Fox Hunting with the Grafton and other packs (London: Horace Cox, 1900), 17. 
scenes would a man carry in his head if he followed hounds in all the counties." ${ }^{51}$ The gorgeous atmosphere was a delight for hunters and was a paradise and retreat at the same time to be able to connect to nature. Similarly, Henry Hardy writes of a Scotland grouse shooting event: "What a beautiful spot that was - with many lakes fringed with rhododendrons. ${ }^{~} 52$ The hunt offered British males an opportunity to revel in country life when industrialization and urbanization were rampant. The hunt was also a way for hunters to return to a feudal time of traditions and customs. Important hunts such as the Berkeley hunt saw their Masters and Huntsmen wearing "yellow coats and green collars with a golden fox" which was said to be a traditional outfit of the huntsmen. ${ }^{53}$ Nostalgia for the past intertwined itself with hunting and became an outlet for many in the times of urbanization and change during the $19^{\text {th }}$ and $20^{\text {th }}$ centuries.

John Smallman Gardiner lamented the urban and commercial growth of England as he wrote: "I question whether our morals by that style of living; which empties our country's feats [sic; possibly seats] to fill the metropolis, or large provincial towns, and whether the manly character that has once distinguished the Englishman has not suffered more, on the side of firmness and integrity, than they gained on that of politeness and elegance, by sacrificing the rough sports of the field to the softer amusements of the assembly and card taste. ${ }^{{ }^{54}}$ Card playing by its very nature was quite feminine because

\footnotetext{
${ }^{51}$ Sir William Beach Thomas, Hunting England; a survey of the sport, and of its chief grounds (London: B.T. Batsford Ltd., 1936), 15.

${ }^{52}$ Henry Frederick Hamilton Hardy, English Sport (London: Country Life, 1932), 116.

${ }^{53}$ Ibid, 116.

${ }^{54} \mathrm{Ibid}$, ix.
} 
there was no show of physical strength and man could not display his power over nature. The refined nature of card playing and other such amusements was looked down upon because hunters wanted to make sure that hunting produced virile, strong men. Industrialization was the culprit for Britons, just as Williamson in India singled out agriculture as the reclamation of lands cut back the forests and the habitat of wild game at the hunter's expense.

Being a good sport was also essential for hunters. Masters of hounds had to have a healthy attitude that emphasized sportsmanship. Sportsmanship in the hunting scenario meant forming strong bonds with those that assisted the huntsman. In India, strong bonds were formed with shikaris or native hunters. However, in Britain it was critical to form strong, loving bonds with their hounds. Nimrod writes that it was very odd whether Mr. Mytton was a sportsman since he never "heard him cheer an individual hound when drawing, or, in chase." ${ }^{55}$ Helping to cheer on a hound drew the master of hounds into the hunting experience and helped give him an active role during the hunting process. Particularly useful was the huntsman who could distinguish a hound in the hunting field simply by his bark. Sir Claude Champion de Crespigny writes of a huntsman named Jack Fricker who was able to "distinguish by tongue most of the hounds in a pack. ${ }^{56}$ Hounds also showed strong favoritism towards hunters. Edward Cox writes about a particular hound's strong attachment towards him. He describes the hound in question, Blossom, as a "bitch whose love for me was as that of a Juliet for her Romeo,

\footnotetext{
${ }^{55}$ Nimrod, “Master of Hounds," New Sporting Magazine 3: 17 (1842: May), 288.

${ }^{56}$ Crespigny, Forty years of a sportsman's life, 64.
} 
or a Francesca for her Paolo." ${ }^{57}$ Things like knowing the names of all the dogs in the kennel were necessary to form strong bonds between the master of hounds and his dogs. Portraits were typically taken with a few dogs or with a favorite dog to help display and build that bond. Henry Hardy writes "though I may handle my gun in an affectionate way, it is not my gun but my dog that I consider my companion out shooting." ${ }^{n 8}$ The bond with a hound was something which was absent in colonial India for companions were shikaris instead of hounds. Masters of Foxhounds took care of their hounds not only to ensure they would be a success during the hunt, but because they truly cared for them. The Manual on British Sports emphasized ways to properly take care of hounds. For example, the author who used the pseudonym Stonehenge writes that after a female dog has given birth the master should wait fourteen weeks before she goes out to hunt. These recommendations were seen to benefit the health of the hound and establish a good relationship between the master and the hound.

Similar to Thomas Williamson's book, many of the English books published by sportsmen served as manuals for novice sportsmen or gentlemen interested in sport. They also served as guides for how to take care of sporting animals such as horses or hounds. The Gentleman's Compleat Jockey written in 1700 gave the reader instructions for how to care for one's horse while out hunting and after the hunt as well. A.S Gent writes that you must give your horse oatmeal and warm water and make sure to rub his sweat off. In addition to grooming the horse, it describes the speed typically used for

\footnotetext{
${ }^{57}$ Edward de Fonblanque Harding Cox, Chasing and Racing; some sporting reminiscences (New York: Dutton, 1922), 113.

${ }^{58}$ Hardy, English Sport, 20.
} 
hunting. The author states the hunter must strive for the speed "between a pace and full gallop, by some termed a full speed." 59 These hints served to create a better sportsman and help gentlemen meet established customs for the hunt. Similarly, sportsmen offered tips to other sportsmen to better their marksmanship and shooting skills. They also provided information to hunters on where to find game. An unnamed gentleman writes about the proper method to be used to successfully shoot a bird: "If your bird flies to your right, aim a little before his head." ${ }^{\circ 0}$ This was the best way, the gentleman argued, to successfully catch your small-game bird. The 'Gentleman' also provided advice on what type of guns to use as well as what type of cartridges (shots) to use for different game. He notes, for example, that "grouse and partridge take shot no.3, 4, and 5." ${ }^{\prime 61}$ Knowledge of the correct cartridge to use would inevitably help the sportsman to kill his quarry and become a successful hunter.

The sportsman also had to be a veterinary expert, in addition to having a considerable knowledge of natural history about animals, their habitat and the different types of species. For example, the author states that itchiness is a common problem for hunting dogs and when there are no physicians or learned men around one must take matters into one's own hands. The author gives the reader the remedy as he writes:" take oil of Flower-de-lys, powder of brimstone, and dry'd elicampone roots, of each a like Quantity, and Bay Salt powdered - mix these powders with the oil and warm it, anoint,

\footnotetext{
${ }^{59}$ A.S. Gent, The Gentleman's Compleat Jockey: with the Perfect Horseman, and Experience Farrier (London: 1700), 52.

60 Gentleman, "Sportsman's Companion or an Essay on Shooting by a Gentleman who has made Shooting his favorite amusement upwards of 26 Years in Great Britain, Ireland, and North America" (NY: 1783), 25.

${ }^{61} \mathrm{Ibid}, 23$.
} 
scratch, and make it bleed, it will do well." ${ }^{\prime 62}$ Medical knowledge was crucial to the health of the dog and the overall success of the hunt. The gentlemanly hunter had to be an all-rounder and jack-of-all-trades.

Sportsmen emphasized the large amount of work that went into a successful hunt. Peter Beckford writes that "cleanliness is necessary around the kennel and upon the dog himself to ensure "good health."63 A healthy dog is naturally a good hunter and therefore the highest standards of hygiene are necessary to maintain. Another author emphasized the need to exercise and a low -fat diet in order to keep the hounds in tip-top shape.

Bonds of friendship were created during the hunts as well. For example, the Duke of Grafton at the beginning of the hunting meet, would "ride round and say 'Good morning' to all." ${ }^{\prime 64}$ The Duke of Grafton who in essence was the sponsor of the Grafton hunt talked with everyone who came to the meet. In fact, simply talking about hunting helped create bonds of friendship. For example, Lieutenant-Colonel E.D. Miller describes how his tutor at Cambridge University enjoyed hearing about his hunting feats and promised him he would come join him in such events. Hunting was here seen as a team effort that developed character, the all important Victorian trait.

\section{Hunting and Masculinity}

Hunting was associated with Victorian public culture as it was associated with

\footnotetext{
62 Sportsman of Berkshire, Essays on hunting Containing philosophical enquiry into the nature and properties of the scent, observations on different kinds of hounds, with the manner of training them. Also directions for the choice hunter ... (Southampton: T. Baker, 1782), 13.

63 Peter Beckford, Thoughts on Hunting (London: D. Bremner 1798), 13.

${ }^{64}$ Elliot, Fifty Years Fox Hunting with the Grafton and other packs, 4-5.
} 
notions of masculinity, physical prowess, competition, and perseverance. Peter Bailey writes that "Manliness as a Victorian ideal derived in part from Coleridge, who conceived of it as that state of intellectual maturity which marked the passing of childhood." 65 Hunting was then an important test for manhood as it encompassed all the characteristics of masculinity and served as an informal initiation rite for young boys who became men. Many British hunters referred to themselves as great, mighty hunters who would battle nature. Linda Colley suggests that foxhunting became popular among the landed classes around the period of the Napoleonic wars, because the value of the landed classes was under attack and they used foxhunting along with uniforms as a way to reassert their dominance. "Nimrod" was the model for most British hunters. Hunters typically wrote about themselves that "the spirit of Nimrod burnt brightly within me." ${ }^{\prime 66}$ Hunting wrote Edward Elmhirst required the potential hunter to have in himself "fair nerve, a sufficient store of bodily vigour, and a proper love of sport for sport's sake. I might almost add, you must love a ride. ${ }^{~}{ }^{67}$ Good horsemanship skills were a prerequisite for most gentlemen and the love of sport was seen as good sportsmanship spirit. 'Vigour' and a 'fair nerve' are associated with physical prowess.

The more physical strength and workout that was necessary for hunting, the more masculine it appeared to be in many sportsmen's minds. For example, hunting in Ireland was a bit different from hunting in England. Edward Elmhirst writes that "a day's hunting

\footnotetext{
${ }^{65}$ Bailey, Leisure and class in Victorian England, 84.

${ }^{66}$ Cox, Chasing and Racing, 49.

${ }^{67}$ Edward Pennell Elmhirst, The best of fun, 1891-1897 (London: Chatto and Windus, 1903), 291.
} 
in Tipperary involves more jumping than very many of you allow yourselves in a week...To the average Englishman, accustomed to sit down and to sit back, as long as his horsemanship permits him, while his horse flies easily from field to field, there is something strangely complicated in what takes place beneath him. ${ }^{968}$ The rough country tested most men's equestrian skills and gave them more adventure rather than the smooth, pleasant rides that were common to the English shires.

Evidence of masculine prowess is also quite evident in British shooting expeditions. In the midst of the hot sun, a British man offers to carry his hunting partner's gun or to get his share of game as he was "looking so pale and weary that I felt very uneasy for him" yet his request "appeared rather to annoy him, for he chose not to be thought my inferior in endurance." The sense of brotherhood among sportsmen was misunderstood as a sign of a lack of masculine power and was deeply resented by his partner since his kind request was seen to be an affront to his masculinity. Even the sportsman believed that it was his strength, endurance and power that very much helped him press on through the heather in search of wild grouse because this was a test of his masculinity as he states his "[masculine] pride would not permit me to retire."

The development of character was an essential component of hunting with etiquette. Sportsmen were well-aware of the connections that hunting has with masculinity. This is not as evident in Indian accounts as it is in British sportsmen's books. Nicholas Cox writes that "Hunting trains up youth to the use of manly exercises in

${ }^{68}$ Ibid, 292. 
their riper age $[\ldots]$ But the exercise of hunting neither remits the Mind to Sloth nor softness. ${ }^{\circ 9}$ Therefore, for Cox hunting was sport that built character in men and promoted manly traits that were much desired. Hunting was described as a merry time in several hunting songs published during the period and along with exercising one's masculine prowess it brought a lot of excitement, joy and amusement to men who engaged in the sport. The development of character, a very important Victorian trait, was sought after well before the $18^{\text {th }}$ century in the hunting field.

Sportsmen were well aware of men who had a strong distaste for certain types of hunting and those men were perceived to be effeminate by sportsmen. John Smallman Gardiner writes the "Delight found in pursuing a poor harmless hare, with a parcel of ugly roaring hounds, to a man of cold flow circulation or a feeble of Mark, effeminate [sic] Temper may appear, on consideration, inhuman, and barbarous as bull-baiting." 70 Manly men understood that hunting was an even battle and not barbaric or cruel. Hunters were concerned with the rise of liberalism and the debate over cruelty to animals because it questioned the merits and morals of hunting. Although Gardiner did believe that some sports such as bull-baiting and other blood-sports were barbaric and cruel. Thus, the refined hunter did not engage in such pursuits, but instead participated in manly sports like hare hunting that developed reason, character, and physical strength as one had to outwit the 'cunning' hare and command hounds to follow her scent.

Nimrod writes that fox hunting helps in "promoting that manly spirit...that

\footnotetext{
${ }^{69}$ Nicholas Cox, The Gentleman's Recreation in Four Parts, (London: 1721), ii.

70 John Smallman Gardiner. The art and pleasures of hare-hunting in six letters to a person of quality. (London: R. Griffiths, 1750), 5.
} 
distinguishes the sons of Britain from all the other nations in the world." ${ }^{.71}$ This idea that sport helped distinguish Britons from others was often borrowed by British sportsmen in colonial India who also proclaimed that sport helped differentiate Britons from Indians. The image that Nimrod displays of a fox-hunter is one that is courageous and virile. Fox hunting in many Britons' minds helped differentiate themselves from other less masculine men. The British hunter was clearly different from the African hunter or the Native American hunter mainly because unlike his imperial subjects he "can only spare time for an occasional rabbit-course" but can not employ "nearly his whole life in the pursuit of the deer, the buffalo, and the bear." Hunting was therefore a leisure activity, not a subsistence activity and as such a special recreational engagement. Similarly, Cecil writes that "a huntsman must be a man of quick and active abilities." 72 The activeness of the male hunter distinguished him from other men and helped promote his aptitude for competitive sport and highlighted his manliness.

Hunting trophies were symbolic emblems of men's masculinity. Natural history publications emphasized the importance of size for acceptable trophies for males. The greatest shooting feat would always have a privileged position in sporting publications and that was what sportsmen strived for. These publications also helped define grand bags. Eric Parker writes that “The trophy prized by the deer-stalker is a good 'head,' that is, the head of a stag carrying fine antlers of so many 'points' [...] In a first-class head the antlers and tines are long, and thick ; the spread, or span, of the horns should be wide

\footnotetext{
71 Nimrod, “Master of Hounds,” New Sporting Magazine 3: 17 (1842: May), 291.

${ }^{72}$ Cecil. "Progress of the Hunting Season." New Sporting Magazine (Jan 1853), 28.
} 
; and as to the number of tines, a really good head should carry not less than ten, while a 'royal' head carries twelve, each antler being furnished with brow, bez (second) and trez (third tines, with 'three on top,' the three top tines forming a cup. Besides carrying a good head, a stag should be big, strong and heavy." $" 33$ The childlike instruction provided to the hunter clearly helped the hunter distinguish a prize from one that was unworthy of being hung on a wall. It also helped hunters prove their manliness and prowess in obtaining such a fine specimen.

\section{Women and Hunting in Britain}

Even though most male hunters emphasized how hunting helped exude their manly traits as gentlemen, many men could not help but comment on the status of women in the hunting arena. Although hunting in Britain was by no means an equal field especially in the $18^{\text {th }}$ century, by the $20^{\text {th }}$ century women were on par with men in the hunting domain. In The Politics of Hunting, Richard Thomas states that "Before 1850, only the wives and daughters of aristocrats and owning Masters were acceptable in the hunting field. Gradually the numbers of women in the hunting field increased; the aristocrats were joined by the wives and daughters of farmers. Women made up 10 per cent of the mounted followers in Leicester in the 1890s." ${ }^{\prime 4}$ Edward Elmhirst writes how "a good dame had not only seen the fox [... and the] huntsman, who was already taking

\footnotetext{
${ }^{73} \mathrm{Ibid}, 20$.

${ }^{74}$ Richard H. Thomas, The politics of hunting (Aldershot, Eng.: Gower, 1983), 53.
} 
advantage of her information." ${ }^{, 75}$ This woman, who Edward Elmhirst describes as old, yet active not only spotted the fox, but also made her point about how to catch the fox clear to others. She clearly did not feel as a subordinate in the hunting circle, despite the fact that most people in the party were men. He goes on to describe hunting women as "Queens of canal barges were they, and their round, rosy faces gave broadest evidence of how yet another class finds delight in the sport of kings and princes." $" 76$ This quote reflects a typical hunting meet where women and men attended. Elmhirst here writes that women were not only present when animals such as foxes were bagged, meaning they were out in the field, but also became leaders and quite knowledgeable in hunting as they had no problem giving male huntsmen advice on how to effectively "bag" the fox. Elmhirst seems to suggest that women were another "class" yet describes them as "Queens" nevertheless. It could be that Elmhirst was being sarcastic in calling them queens, but most likely it describes women as elite figures who enjoyed the sport. Even though hunting was a typically male sport, it was not so exclusively masculine that it restricted female hunters. Sir Claude Champion de Crespigny writes that "Lady Humphrey was known as one of the most excellent horsewomen of the hunt." ${ }^{, 77}$ Similarly, John Elliott wrote a history of the Grafton hunt, writes "A lady named Miss Nellie Holmes was out, topping the fences like a bird, to the admiration of all ; and when we came to the brook, over she went... That was the first

\footnotetext{
${ }^{75}$ Elmhirst, The best of fun, 69.

${ }^{76} \mathrm{Ibid}, 177$.

${ }^{77}$ Crespigny, Forty years of a sportsman's life, 68.
} 
lady whom I saw go over a country. There is one certainty about ladies, what one does another will do, if it be worth the doing." 78 John Elliott was quite impressed with female riders and by the end of the book he has witnessed many more lady sportsmen involved in the Grafton hunt. He closes to say that "Great credit is due to the Ladies for the way in which they rode. As a rule they are much more attentive than the men, and ride with more nerve. ...It was marvelous how forward they finished" suggesting that they were not scared of riding, had great horsemanship skills, and were quite swift in the hunt. ${ }^{79}$ Such men as de Crespigny and Elliott appreciated female hunters who excelled at the sport.

On the other hand, there were some men who were quite conservative and argued against women who hunted. The Earl of Ladythorne argued that "women had no business out hunting" because hunting was supposed to be a sport for men. ${ }^{80}$ The common presumption was that women would not be able to withstand the dangers associated with the hunt. Sabretache writes that in "Leicestershire, it went, is inhabited by the hardest men and the softest women." ${ }^{\prime 1}$ While the author acknowledges that in the Victorian era there were female hunters, he still claimed that the age-old adage remained true.

The nineteenth century was the peak of the fox hunting craze. Women also joined in the fox hunting experience. A fox hunter explains that Mrs. Dalyell was "as fond of fox hunting as her husband is, and one of the best and boldest horsewomen in

\footnotetext{
${ }^{78}$ Elliott, Fifty Years Fox Hunting, 14.

${ }^{79} \mathrm{Ibid}, 283$.

${ }^{80}$ Sabretache," Monarchy and the Chase (London: Eyre and Spottiswoode, 1948), 128.

${ }^{81}$ Ibid, 128.
} 
Scotland. ${ }^{92}$ Despite the fact that there were several women who were avid sportswomen, fox hunting typically was revered as a masculine enterprise. On the whole, it seems that women were very much accepted as sportswomen.

\section{Conflicts in Hunting: Scorn Against the Poachers and Agriculturalists and Hunters and the Debate on Artificiality}

Hunting in Britain according to Emma Griffin reflected the "power struggles" inherent in the "class divisions and social mores" of British culture. There was a constant struggle between the hunter and animal, hunter and the poacher, hunters and farmers, aristocrats and the poorer classes, and the king and other potential hunters. Scorn against poachers continued in Britain as well, especially in the later part of the $19^{\text {th }}$ century. The Poaching Prevention Act of 1862 allowed any peace officer to search any person if they had reasonable suspicion that the person was stealing or killing game against the law. The Poaching Prevention Act also set out to define game and it included British favorites such as pheasants, partridges, snipes, red grouse, and eggs of all the aforementioned game. Various Night Poaching Acts were also passed in the mid- $19^{\text {th }}$ century to prevent poachers. The wrath of gamekeepers and farmers was directed against poachers. Sportsmen by the $19^{\text {th }}$ century were well aware of what distinguished themselves from the poacher. Therefore hunting became an acceptable sport because rules and regulations were followed whereas the poacher disregarded the law and often acted in an uncivilized manner.

\footnotetext{
82 Nimrod. "Nimrod's Northern Tour” New Sporting Magazine 11: 66 (Oct 1836) p. 371.
} 
The Manual on British Rural Sports also discussed the various methods of deception that the common poacher utilized..$^{83}$ While there is an absence of writing by poachers, there is a proliferation of records and descriptions on poachers. These writings represent a bias against the poacher and almost none of the records objectively describe their activities. The poachers from London were described as a gang who used dog-carts to roam on which they sat and shot at game with a fowling piece. They would also use unethical methods of retrieving game such as killing pheasants when they were eating. They would also net grouse and partridge. Netting was unethical for game which was not vermin. Furthermore, the poachers' constant trespassing and disregard for property was a common complaint among the landed gentry and gamekeepers.

Just as the British in the India held great disdain for "poaching" techniques such as snaring, netting and trapping, most Britons highlighted their hatred for the aforementioned methods of hunting. The poacher did not follow trespassing and property laws and usually sought game birds for his table. The classic Tom Jones by Henry Fielding epitomizes the opinion that most sportsmen had for poachers. The gamekeeper lost his job because he "espied a hare sitting in her form. This hare he had basely and barbarously knocked on the head, against the laws of the land, and no less against the laws of sportsmen." ${ }^{" 44}$ The lack of proper hunting etiquette and the cruelty which the gamekeeper inflicted on the poor hare was seen as unbecoming of a gamekeeper. The

\footnotetext{
${ }^{83}$ John Henry Walsh, Manual of British Rural Sports: comprising shooting, hunting, coursing, fishing, hawking, racing, boating, pedestrianism, and the various rural games and amusements of Great Britain (London and New York: G. Routledge \& Co., 1856), 54.

${ }^{84}$ Henry Fielding, Tom Jones (London: 1861), 152.
} 
utter disregard of property laws was also unfathomable in Mr. Allworthy's, (the property owner's) opinion. Not only did this single transgression cause the gamekeeper his position, but he was also not given the chance to defend his actions, since this unmoral act was entirely unacceptable. Similarly, the triumph of the gamekeeper over the poacher is found when glossing over several hunter's accounts. Sir Claude Champion de Crespigny writes of Caleb Simonds, the Savernake Forest gamekeeper of Tedworth country as an example. He praises Simonds as a man who was extremely fearless and who killed one of the armed poachers upon attack. ${ }^{85}$ The fact that he did not run from the scene, but confronted the assailants with no weapon showed his dedication to the principles of proper hunting, rather than what he deemed to be wanton shooting.

While gentleman in England required their social lowers' assistance for hunting, they nevertheless distinguished themselves as a separate class. Gentlemen did have aversions to poaching-like activities that did not involve the use of guns. One author who went by the penname "Gentleman," writes that "I am so very averse to netting birds with setters." ${ }^{\circledR 6}$ The gentlemen preferred to shoot at birds instead, because it helped a sportsman become a great marksman, a quality that made one a refined man. This concern with developing character reflects broader trends in British society where poaching-type activities were looked down upon by elites in an effort to mark the sensibilities and cultivation of virtues in gentlemen.

In Ireland, there were also methods introduced to check the power of

\footnotetext{
${ }^{85}$ Crespigny, Forty years of a sportsman's life, 69.

${ }^{86}$ Gentleman, "Sportsman's Companion or an Essay on Shooting by a Gentleman who has made Shooting his favorite amusement upwards of 26 Years in Great Britain, Ireland, and North America" (NY: 1783), 20.
} 
gamekeepers and poachers. Magistrates required licenses for game dealers. ${ }^{87}$ In order to get a license, the applicant had to provide a list of people that he bought game from and to keep records of the amount of game that was bought. In such a manner, magistrates were able to curtail the illicit selling of game and to check the records with the landowners to ensure the fruits of the poaching could not be sold.

Just as British hunters in India were dependent on Indian servants, British hunters were dependent on farmers, gamekeepers and their own neighbors not only to assist with the hunt, but to allow them passage over their lands or crops. Farmers helped breed horses for Masters of Harriers or Whippers-in to use during their hunting trips. In addition, acquiring the Gamekeepers were especially crucial because they helped eradicate pests and maintain dwindling stocks of game. While it appeared to be a mutual symbiotic relationship, the law favored hunters. Farmers were required to allow hunting on their lands. As Richard Thomas writes, "in 1788 a court stated that chasing a fox on to another person's land was acceptable. ${ }^{988}$ The court considered eliminating foxes more important than a temporary trespass or trampling of crops. The court's decision also reflected a bias towards the aristocracy. Most farmers were happy to get rid of any animals close by to their crops.

Conflicts between hunters and farmers were quite common however. The sense of duty towards the farmer often led to negotiations between the farmer and the huntsman. Every hunt in the $20^{\text {th }}$ century established a poultry fund to reimburse the poultry-keeper

${ }^{87}$ George Frederick Underhill, A Century of English fox-hunting (London: R.A. Everett, 1900), 273.

${ }^{88}$ Thomas, The Politics of Hunting, 60. 
for damage to his chickens or to the lands where the chicken resided. Farmers were however gracious hosts to hunters mainly because they wanted foxes off their land. Henry Hardy writes “I often ran over his [the farmer's] land, and though he may have sworn behind my back he never said a word to me nor claimed a farthing's damage." 89 Disputes over damage done to the land due to foxhunting were quite rare.

As game began to decline, more artificial means began to be implemented to preserve the activity of hunting in the island nation. The gamekeeper generally was in charge of artificial rearing of game birds and ensuring that stocks of game allowed for plentiful hunting opportunities. Other artificial means such as selective breeding of hounds also helped hunters acquire an advantage over game. Cubs were also imported to England and sold at Leadenhall Street. They usually arrived from continental Europe from nations like France and Holland.

Artificial methods of hunting were often instilled to protect some prey from their predators. The prey usually had some benefit to mankind - they tasted great and were part of the usual assortment of game that a sportsman bagged. However, there are some reasons that hunting was engaged in even when an attack on prey had no direct relevance to hunters. For example, otter hunting was usually conducted because otters ate trout and salmon and other important fish for commercial fishermen, but sometimes merely because otter hunting was much cheaper than fox hunting since it typically did not need a horse. It was conducted on foot.

\footnotetext{
${ }^{89}$ Hardy, English Sport , 41.
} 
The craze for foxhunting often led to a spike in bagged hunting (foxes caught by a bag and then reintroduced into the hunting location). While most masters of foxhounds and huntsmen derided the use of bagged foxes, they nevertheless had to resort to bagged foxes due to the decline in game in certain counties. Hunting accounts taken from writings of sportsmen give evidence to the surge in bagged hunting. For example, E. D. Cuming writes "When Squire Osbaldeston hunted in Suffolk, Season 182203, Mr. E.H. Budd used to buy half-grown foxes for him from Hopkins in Tottenham Court Road, at thirty shillings a brace, and send them down in a covered cart, ten or twelve brace at a time. ${ }^{\prime 90}$ Other sporting books emphasize that the huntsmen is often not told about the fact that these foxes are bagged, but the foxes that are hunted are really bagged.

The interest in fox hunting also led to a subsequent decline in other forms of hunting in Britain. For example, otter hunting declined in places like Wales as the craze for fox hunting engulfed the nation..$^{91}$ The decline of other forms of hunting continued into the $20^{\text {th }}$ century as harrier hunting packs often transformed into fox hunting packs. For example, Richard Thomas writes that the number of harrier packs declined from 101 in 1905 to 40 packs in $1935 .^{92}$ The rise of foxhunting had a tremendous impact on the hunting atmosphere in Britain both in the $19^{\text {th }}$ and $20^{\text {th }}$ centuries. The obsession with hunting also saw the decline of the "all-round" sportsman and saw the rise of the foxhunter.

\footnotetext{
${ }^{90}$ Cuming, British sport past and present, 7.

91 Thomas, The Politics of Hunting, 50.

92 Ibid, 48 .
} 
There were certainly advocates who longed for a time when less artificial methods could once again be used during the hunt. Hunters were keenly aware of the fact that a lack of preservation could mean an end to sport. This was most evident in the turn of the $20^{\text {th }}$ century. In several published accounts, statements such as the following represented a possible sense of doom in the hunting arena. Edward Harding de Fonblanque Cox wrote "as long as the supply of fur held out we could always be sure of showing first-rate sport; especially in that part of the country which included the grass lands of the Aylesbury Vale. ${ }^{.93}$ The Aylesbury Vale had a stock of numerous hares, however those hares would not replenish themselves with indiscriminate shooting.

A need to preserve dwindling species resulted in staged hunting. Artificiality in hunting was a concern in Britain. W. Earl Hodgson writes that "shooting driven deer is mere vulgar brutality" and "One may stalk a stag in the orthodox fashion and not be squeamish, for all men have a natural impulse to hunt and kill ; but blazing at deer driven to the muzzle of your rifle is not hunting. It is revolting cruelty." In many sportsman's eyes, there was a clear distinction between accepted practices of hunting and artificially accelerated hunting that had no concern for the slaughter of game.

Some hunters emphasized the fact that preservation methods did not lead to the decline of sport. Edward Cox writes about "cranks who want to differentiate between the degrees of cruelty entailed in the pursuit of field sports" who state that "to chase a poor deer, released from a cart, until it dies of exhaustion, drowns itself...[is] not sport, but

\footnotetext{
${ }^{93}$ Cox, Chasing and Racing, 56.
} 
diabolical brutality." ${ }^{94}$ Cox's view highlights the point that many of his opponents in opinion believed that hunting carted deer was not a true sport. Cox states that in actuality the carted deer is "in perfect condition as a trained race-horse. He has been deprived of his head honours, and is fit to run, not for his life, but to give the hounds (whom he knows and fears not) and the field a good run for their money. When he is tired, he looks out for a convenient stable or farm building. Then he calmly awaits the arrival of the pack [...] to take him back to his paddock." 95 The fact that most times carted deer were not killed testifies to the conservative nature of the carted deer scheme. The mere thrill of running after a fast beast often gave hunters in the party a sense of accomplishment.

The Society for the Prevention of Cruelty to Animals (RSPCA) in 1824 marked a time when concerns about cruel treatment of animals, including game, came to the forefront of national currents. Morally, Puritans were opposed to hunting. Methodists were staunch supporters of Puritans when it came to hunting. The move against hunting came during the flurry of debates on what was proper and civil behavior for aristocrats and gentlemen. Just as the $19^{\text {th }}$ century prohibition on dueling, blood sports were lobbied against in order to have them eliminated. As mainstays of the commoners, they were viewed as bloody, unorganized, and unsportsmanlike. As Richard Thomas states, radical intellectuals also supported the RSPCA. By the $20^{\text {th }}$ century, with the aftermath of World War I, the Prince of Wales became the president of the RSPCA, even whilst he

\footnotetext{
${ }^{94}$ Cox, Chasing and Racing, 57.

${ }^{95} \mathrm{Ibid}, 58$.
} 
was an avid fox hunter. This is similar to colonial India where several game associations main goals were preservation activities, and the heads of these associations were avid sportsmen. As Thomas has shown, based on an RSPCA poll, most members wished to end hunting wild deer with hounds because they perceived of the nature of the sport as cruel. The prominence of carted deer especially due to the Royal buckhounds, Mid Kent and Norwich Hunt packs possibly swayed voters towards finding the nature of hunting wild deer cruel. The creation of the Society led to a clear distillation on the definition of a sportsman. For example, a sportsman was someone who was honorable. A sportsman treated his hunting animals (hounds and horses) well and did not drive over animals.

The opposition against fox hunting gained momentum after World War I. Hunting associations helped defend the right to hunt amidst the opposition. The Masters of Foxhounds association emphasized the fact that to get rid of hunting meant taking away the supply of horses that would be provided to the War Office. ${ }^{96}$ Masters of Fox-hounds also helped drive the horse breeding industry.

The codification of honor during the Victorian era also led to a marked differentiation between dignified hunting and random shooting. Pigeon-shooting which occurred in Hurlingham Club in 1871 was fiercely opposed by the general public, mainly because it was constituted as cruelty towards animals and perhaps because pigeons could not serve on game platters. Furthermore, random shooting at animals could not be constituted as hunting since hounds were not used and the shooter seemed to have an

\footnotetext{
${ }^{96}$ Alexander Henry Higginson, Two centuries of foxhunting (London: Collins, 1946), 225.
} 
unfair advantage. The Times declared the event as something that was "practised by aristocratic amateurs out of mere wantonness and love of killing. ${ }^{.97}$ The obvious lack of restraint by aristocrats who did not have enough experience to excel at a "proper sport" such as hunting was viewed in a derogatory manner and the apparent lack of restraint was viewed as a lack of self-control and something that was not very Victorian since it did not emulate a self-disciplined stance.

\section{Nascent Ecological Awareness}

The British were aware of declines in game. John Henry Walsh who uses the pseudonym "Stonehenge"writes in the $19^{\text {th }}$ century that "The bustards, great and little are now so exceedingly rare. ${ }^{998}$ Lieutenant-Colonel E.D. Miller who served in India also discusses the steep decline in game in Britain. In Fifty Years of Sport he writes "We were never short of a job in the shooting season, for when the partridges and pheasants gave out there was always plenty of rabbits." 99 However, in 1921, he writes "Not a pheasant or a partridge for miles." ${ }^{100}$ Miller attributes the lack of game to the destruction of the woods and the building of a railroad to facilitate the war effort against Germany. It is true that industrialization and urbanization has been an impediment to the hunt. Barbed wire

\footnotetext{
${ }^{97}$ Bailey, Leisure and class in Victorian England, 85.

${ }^{98}$ John Henry Walsh, Manual of British Rural Sports: comprising shooting, hunting, coursing, fishing, hawking, racing, boating, pedestrianism, and the various rural games and amusements of Great Britain (London and New York: G. Routledge \& Co., 1856), 54.

${ }^{99}$ Lieut.-Col. E.D. Miller, Fifty Years of Sport (London: Hurst and Blackett Ltd, 1925), 18.

${ }^{100} \mathrm{Ibid}, 47$.
} 
has also led to shorter hunts and a good deal of damage done to all game animals in addition to hounds. Red deer were also only found in Scotland and stag was almost extinct due to heavy hunting prior to the $18^{\text {th }}$ century. Part of the decline of game was also due to the shooting of game itself.

Gamekeepers as a result of their employment were automatically involved in preservation efforts. However, their preservation efforts often meant an attack on "vermin."The Manual on British Rural Sports also outlined the gamekeeper's duties and clearly categorized which animals could be taken and which should be preserved. "Stonehenge" writes, "All four-footed vermin should be trapped or poisoned." ${ }^{\prime 101}$ Guns were not always required for the gamekeeper's possession since he was to be a man who devised time-honored traditions. Even though the British in India did not consider poisoning animals to be hunting and condemned it there, in Britain itself gamekeepers accepted it in the $19^{\text {th }}$ and $20^{\text {th }}$ century so long as it helped the proliferation of game birds. Walsh states that for "eagles, hawks, buzzards, and kites, arsenic is the best" although he cautions the gamekeeper that dogs can be inadvertently poisoned. ${ }^{102} \mathrm{He}$ also advises that arsenic should be inserted into the brain or liver. Hawks in particular were regarded as nuisances because they attacked partridges and pheasants. Strychnine was commonly used for the magpie, raven, and jays. Gamekeepers tried to eliminate these birds because they destroyed game birds' eggs. Poison was clearly not a righteous method of killing animals, but because these animals were classified as vermin and

\footnotetext{
${ }^{101}$ Walsh, Manual of British Rural Sports, 3.

102 Ibid, 13.
} 
because they caused harm to other valuable game or crops they needed to be eradicated. Medieval methods of hunting were severely looked down upon during the 19th century with the rise of moral objections to cruel behavior inflicted upon animals. Nevertheless, vermin were always the exception to the rule.

In addition to using poison, gamekeepers used a variety of methods to ensure that vermin were eradicated. For example, steel traps were used for weasels. Sometimes bait such as an egg or the liver of a rabbit was used in order to lure the weasel. Rabbits were hunted because they were classified as vermin as well, particularly for farmers.

Hedgehogs were found by terriers. Just as the scent of opium was used to attract animals in colonial India, traps were sometimes rubbed with the herb valerian in order to attract an animal such as a wildcat to the trap. ${ }^{103}$ These methods were denigrated in India by sportsmen and government officials, however in Britain it was quite acceptable in order to ensure the artificial rearing of partridge, pheasant, and grouse and to ensure that crops were not damaged.

In colonial India there was a discernable debate about the killing of females, indiscriminate shooting, and whether it was right to kill baby animals or not. There is hardly a dialogue in Britain regarding the criminality of these shootings. The main reason that the British tended to avoid shooting baby animals or females was because they provided the hunter no sport. Other reasons were that they were tasteless and therefore were avoided. For example, "Stonehenge" writes that "The suckling-hind is

${ }^{103} \mathrm{Ibid}, 7$. 
poor and tasteless, and should be allowed to escape from the rifle-ball."104 There was really no discussion about the fact that the suckling hind should be allowed to live because it was feeding another animal. Instead, the discussion focuses on whether it is fit for the table or not. This is also the reason that game ducks such as teal were prized for their rich flavors. Other meek animals were also avoided. Ptarmigan which was often described as a "dull and stupid" bird was avoided because it did not offer "good sport" for the sportsman. Ptarmigan did not fly away or flutter its wings in fright in a hurry to move away from the shooter. Men often believed that they needed an equal battlefield in the hunting arena and easy sport was something which was avoided because it did not require an intense amount of effort or skill.

While some $19^{\text {th }}$ century sportsmen seemed to demonstrate or show an ecological awareness, excess was still quite common in Britain's hunting arena in the late $19^{\text {th }}$ century. John Elliott writes of Frank Beer's diaries. The huntsman of the Grafton hunt wrote on August $24^{\text {th }}$ of 1880 : "Began cub-hunting, hunted forty days, killed twentythree and a half brace of foxes." 105 Hunting was by no means restrained especially for hunting favorites like fox. A huge number of game birds were also killed. Cuming writes of the largest bag of grouse where on August 30, 18881070 birds were shot in 20 drives. ${ }^{106}$ A breathtaking, astounding number of winged game was killed. The doublebarrel gun had the ability to shoot more game and this had a tremendous impact on the

\footnotetext{
${ }^{104}$ Ibid, 83.

${ }^{105}$ Elliott, Fifty Years Fox Hunting, 14.

${ }^{106}$ Cuming, British sport past and present, 97.
} 
amount of game that could be taken in few moments.

While British men in India emphasized the fact that Indian hunters did not hesitate to kill female animals and baby wild animals, British hunters in Britain routinely shot cubs and it was a very accepted practice especially among aristocratic circles. In fact the Earl of Yarborough stated that cub hunting or hunting of young foxes is a "very essential part of the hunting establishment, and it is necessary for many reasons, the most important of which is that it enables the huntsman to gain a thorough knowledge of his pack, and teaches the hounds to know and obey him."107 Therefore, the denigration that several British residents in India used against their Indian counterparts was an imperial ploy to dismiss Indian hunters as poachers devoid of morality. This same technique was used in Kenya as white hunters became the only valid hunters of the region. Cub hunting would not have been acceptable in colonial India.

Over time, changes in the landscape of Britain occurred due to the arrival of motor cars, railroads, and enclosures of farm lands, which in turn, helped change the nature of the traditional hunt. Railroads and motor cars helped hunters travel to distant meets and helped elite Britons residing in London attend country hunting engagements in the shires. Similar to colonial India, hunting boosted the local economy of small towns. When grouse shooting opened in August every year, men came from all over England usually by carriage accompanied by dogs and resided in local inns close to the shooting meet. Enclosures often limited the spaces which hunters could freely ride over. The

${ }^{107}$ Earl of Yarborough, “Cub Hunting, ” Badminton Magazine 1: 3 (1895 Oct): 378. 
widespread use of the gun also led to a significant decline in game.

By the end of the $19^{\text {th }}$ century, the tide had completely turned against the poacher and working-class sports with laws making poaching illegal and banning working-class 'blood' sports, which were deemed cruel. Similarly, by the turn of the century in colonial India, there was an upsurge of demarcation against the poacher and commoner sports such as the throwing of stones at birds and wild animal fights. In colonial India, these activities were seen to represent the Oriental uncivilized nature of Indian society and of the Indian himself. The British who constructed this narrative about Indian "hunters" ignored the working class and poachers in Britain, but perceived that all British hunters emphasized proper etiquette and hunting skill. In Britain, such activities were no longer tolerated as part of working class culture and the aristocracy, upper classes, Christian Methodists/Puritans, and the RSPCA worked to eliminate these elements of the lower classes out of mainstream society. The Ground Game Act of 1880 helped introduce the lower classes to hunting however winged game was off limits. This was seen to be an alternative to cockfighting and other blood sports like bear-baiting.

\section{Conclusion: The Main characteristics of British hunting}

British hunting represented the epitome of the goals of the public schools: masculine ardor, a sense of pride, and team spirit. The royal house and elite sought to inculcate honor, manliness, privilege and power over their dominions in a symbolic manner through royal hunts. Women also sought to find a place for themselves in the hunting framework in Britain. One of the marked shifts that occurs in Britain is the 
introduction of artificiality both by gamekeepers and by the hunting industry as a whole even by the $19^{\text {th }}$ century. The sportsman became an all-rounder who needed to be both a veterinary expert, taxonomist, and gun expert. Hunting was most widely known as an aristocratic, leisurely sport, however poaching has also been a mainstay of the history of hunting in England. In addition to scorn against poachers, concerns about artificiality and cruelty to animals were also large looming questions in the history of hunting in Britain. The current chapter describes hunting in Britain. Subsequent chapters will show that hunting in India was not merely an imitation of hunting in Britain. 
Chapter 2: Shikar: The Regal Sport of the Sahibs and Nawabs in India Before 1800

This chapter covers three important phases in the history of hunting in India before 1800, hunting in India before the British arrival; the British encounter with hunting in the $18^{\text {th }}$ century; and the emergence of an Anglo-Indian hunting tradition.

There are limited records of tribal hunting before the Mughal time period, so this chapter focuses on Mughal and princely hunting. One of the goals of this chapter is to provide a baseline to compare hunting in India both before and after the British arrive in order to identify both the similarities and differences between hunting in Britain and in India. The purpose of this chapter is to show that the Indian rulers had a distinct hunting tradition and that the British developed a sense of hunting etiquette which combined elements of British and Indian hunting traditions. The main arguments of this chapter are that the British were impressed by the freedom of hunting in India, hunting became an elite sport, hunting became a source of social conflict, and there 
emerged major similarities between British and Indian hunting traditions.

\section{Hindu literature}

Hunting was permitted among the Kshatriyas or warrior castes during the Vedic Age, which was roughly from 1,500 to 1,000 BCE. For instance, in the Mahabarata, which was written in $200 \mathrm{CE}$, it is recorded that Drona orders Arjuna to shoot and he kills a bird with one arrow. Drona exclaims "This indeed is marksmanship."108 Hunting was often used to perfect marksmanship and make the warrior ready for battle since ancient battles in India were commonly fought on chariot with the use of bows and arrows. Using birds as target shots helped mold and build a masculine and perceptive man. In the Rig Veda, the Hymn of Brhaspati (XC) refers to hunters' arrows suggesting that hunters were an everyday part of Hindu society. ${ }^{109}$

\section{Mughal Hunting}

The Mughal Empire was one of the first Empires since the Mauryan Empire which unified India. The Mughals were foreign Muslim rulers. It began in 1526 and ended in 1858 with the establishment of British crown rule. Culture flourished under Mughal rule and the edifice of Mughal influence had a lasting impact on the subcontinent. British conceptions of the Mughal rulers portrayed them as "despotic" Oriental kings who lacked any restraints. A lack of restraint was seen among many Mughal hunters who killed game by the hundreds. The capturing of game marked the

108 R. K. Narayan, ed. Mahabarata: A shortened Modern Prose Version of the Great Indian Epic (NY: Viking Press, 1978), 13.

109 Jaraslav Pelikan, trans., Sacred Writings of the Rig Veda (Delhi: Motilal Barasidas, 1992), 127. 
masculine prowess and reinforced the greatness of the Mughal ruler, justifying his rule over the Indian subcontinent. The evidence of Mughal hunting challenges earlier scholarship by scholars who argue that pre-colonial Indian rulers' practices were ecologically sound and sustainable. ${ }^{110}$ In fact, a thorough overview of the hunting records of Mughal rulers shows that they were no more ecologically conscious than the British and acted in similar ways.

The Mughals who were Turkic Muslim rulers were avid hunters. During interludes of restwhen they went on their fighting expeditions, they would often form "hunting circles" so they could hunt wild game. "Hunting circles" were simply manmade enclosures formed by men standing in a circle. In the same way as the British, the Mughals would write down the types of game they encountered, in the lands they had recently conquered. This surveying of the land, as Bernard Cohn states, was important to demonstrate power over the newly conquered lands. ${ }^{111}$ Babur, who ruled from 15261530, recorded in his memoirs, the Baburnama, the different types of game that were present in India. Just as the British appreciated the "fine specimens" that they encountered in India, so too did the Mughals. The Mughals named animals not as the British did with Latin names, but with their Turki names, while also giving the Indian name commonly used for that animal, similar to British writers' description of Indian game. Like British accounts, Mughal accounts of these animals were very descriptive.

\footnotetext{
110 Madhav Gadgil and Ranajit Guha, This Fissured Land: An Ecological History of India (Berkeley: University of California Press, 1992), 86.

${ }^{111}$ Bernard Cohn, Colonialism and its forms of knowledge (Princeton: Princeton University Press, 1996), 3.
} 
Babur recorded the colors of the deer, the presence of hair on the animal, differences between does and deer, the activities of monkeys, the speed of squirrels, and the beauty of peacocks. Unlike British accounts, Babur does not discuss the sacredness of such animals for the Hindus, but instead he highlights the relevance of the animal to Islam. For example, he relays the fact that the Islamic scholar Imam Abu Hanifa states that peacock is lawful food for Muslims. ${ }^{112}$ Like British accounts, Babur states where game was plentiful. For example, he discusses the region of the parrot in Bajaur in present day Pakistan. Like the British accounts of wild game, taxonomy for classification purposes is utilized in Babur's memoirs. He discusses, for example, different types of sand-grouse and bustards.

Babur, the first Mughal Emperor of India, was originally from Central Asia. ${ }^{113}$ It was there that he first engaged in hunting in his native homeland of Central Asia. Near Andijan in Farghana on the Central Asian plateau, Babur recorded that "there are many foxes of fine colour" and that he would "ride hunting every two or three days" and fly his hawks after the pheasants. ${ }^{114}$ Hawking was a popular sport that Babur initiated and that would be followed by several maharajas. He often killed several deer during a single hunting trip. ${ }^{115}$ Babur frequently hunted during his travels and his military expeditions. For example, while waiting to visit Jahangir Mirza, he hunted goats and wild sheep on 105 Babur Emperor, Babur-nama in English, trans. Annette Susannah Beveridge (London: Stephen Austin and Sons Ltd., 1969), 488-493.

112 Ibid, 493.

113 John Richards, The Mughal Empire (Cambridge: Cambridge University Press, 1995), 9.

114 Babur, Babur-nama, 114.

115 Ibid, 492. 
the hills. ${ }^{116}$ This was also something the British did as well as they generally shot their way around India. Fanny Eden noted how her nephew, William Osbourne, shot along the way as he traveled from the Upper Provinces back to Calcutta.

The typical Mughal hunting style was to form a "hunting circle" to encompass the wild game and then shoot at them with bows and arrows on horseback while simultaneously using swords to kill the beast. Easy bows or stiff bows were used to shoot deer. In Kattawaz, which is in present day Afghanistan, Babur noted how in 1508 the deer and donkeys were quite fat. ${ }^{117}$ Killing a fat beast was very enticing for the Mughals. Another Mughal in Babur's company noted the fatness of the game compared to wild animals in other locations. The Mughals felt it was a pleasure to kill such a fat beast. This helped display their manliness over the game of Afghanistan.

Similar to the British, the Mughals had a great affinity for capturing the beauty of wildlife. Pretty birds or picturesque hunting scenes were very much sought after and emperors ordered artists to capture their beauty. Humayan, the son of Baber, who was the second Mughal Emperor, for example, ordered an artist to render in art a pretty wild bird. ${ }^{118}$ The British did not usually commission artists to create the picturesque scenes, preferring to sketch themselves, especially in the $19^{\text {th }}$ century. In the $20^{\text {th }}$ century there were cameras to capture the trophy of the hunt, however hunting scenes were almost

\footnotetext{
116 Ibid, 296.

117 Ibid, 325.

118 Jouhar, Tezkereh Al Vakiat, or Private Memoirs of the Moghul Emperor Humayun, trans. Major Charles Stewart (NY: Augustus M. Kelley, 1969), 43.
} 
never displayed in art.

Unlike the British and educated Indians who preferred to use guns, most Mughals hunted with bows and arrows or swords. Humayun is recorded discharging "his arrow, which struck the animal behind the ear, and it fell struggling on the ground ; at which all the Persians were astonished" when he was at a hunting enclosure near Persepolis. ${ }^{119}$ Humayun's excellent marksmanship contributed to his reputation as a "fortunate" and "able" ruler. Later Mughal emperors typically used swords, although bows and arrows seem to be the standard hunting gear that was used. Hunting was a form of diplomacy between two kingdom's princes, just like it was for the British and the maharajas. Like the maharajas and the British, Humayun and the Prince Bahram of the Persian Empire amused themselves at sport till mid-day. ${ }^{120}$ This helped forge and strengthen relations between the Mughal and Persian Empires.

Another Mughal ruler, Akbar, had an enormous hunting enclosure, which Jahangir's Memoirs state included 11, 000 antelope and 12,000 nilghais, rams, rhinoceroses, and ostriches. ${ }^{121}$ By the reign of Akbar (1556-1605), guns were introduced and typically used for hunting expeditions. Jahangir discusses his father, Akbar in very fond terms. He writes that Akbar enjoyed hunting and even named his own fowlingpiece, which is typically used to shoot birds, Jennauzah. He even wrote a poem or shair dedicated to his fowling-piece. Jahangir recalls Akbar's short poem he wrote: "In the

\footnotetext{
${ }^{119}$ Ibid, 67.

${ }^{120} \mathrm{Ibid}, 66$.

${ }^{121}$ Jahangir Emperor, Memoirs of the Emperor Jahangueir, trans. Major David Price (London: J. Murray, 1829), 46.
} 
pleasures of the chase with thee, my soul breathes fresh and clear (tawzah), But who receives thy fatal mission, sinks lifeless on the bier (jennauzah)." ${ }^{22}$ The poem recalls his dear memories of the refreshing hunting experience followed by the unfortunate demise of the animal at the hands of his fowling-piece. The nostalgia of the hunting experience was similarly recorded in British Tent Club records in which hunting songs can be found. In pre-colonial India, hunting was the privilege of the elite, royal minority. The Mughal Emperors from Babur to Aurangzeb were avid hunters. They sought not only to rule over their subjects, but to control the environment as well. A Mughal carpet from Lahore which was woven during Akbar's reign captures the disarray of the animals and the bravery of the Mughal hunter on his chariot. ${ }^{123}$ Symbolically, this refers to Mughals bringing stability and order over the chaotic Indian environment through their rule, thereby legitimizing their presence in India. Unlike the maharajas, the Mughals used hunting cheetahs, rather than shikaris, to accompany them on their hunting expeditions. Control over wild game was essential for the Mughals as they asserted authority over their native subjects. Enclosed hunting grounds called the qamarga were where corporal punishment took place. For example, Akbar kept a prisoner in the qamarga to be trampled by the elephants as punishment for his crime. ${ }^{124}$ Hunting was not simply an imperial task for the Mughal Empire, but was also an activity which allowed the

122 Ibid, 47.

123 Indian Mughal Hunting Carpet. 1595. Lahore. Boston: Museum of Fine Arts. ${ }^{124}$ AnneMarie Schimmel, Great Mughal Empire: History, Art and Culture (London: Reaktion Books, 2004), 96. 
Mughals to enjoy waterfalls, streams and nature in general while simultaneously enjoying sport.

Men were usually employed at the spot for hunting activities. The British would follow Mughal policies of paying men who assisted with the hunt. For a hundred antelope Qamargha hunt held on August 17, 1608, Jahangir distributed Rs. 5,000 to the ryots who helped in some way to ensure that the hunt took place smoothly. ${ }^{125}$

Similar to what was done in Britain in the $19^{\text {th }}$ century, Jahangir bred certain animals like markhors and goats. Although the British bred certain game like pheasants and partridges because they were sought after for sport, Jahangir bred certain animals because of his interest in breeding these animals. Jahangir writes that "I enjoy them immensely and take great care in the breeding." 126 There are strong correlations between European curiosities and the Islamic medieval world that also took an interest in such curiosities for the goats were not from India but from the Arabian port of Dafar. Strange curiosities were also brought to the court of Jahangir. For example, Shinwari Afghans brought a ram who had one horn (two horns grown together). Jahangir quickly ordered the artists to capture it. ${ }^{127}$

Jahangir, received a gun from his father, Akbar, which was named Droostandauz or that which never misses. He writes that with the use of Droostandauz he killed twenty

\footnotetext{
125 Emperor Jahangir, Tuzuk-iJanagiri-Jahangirnama: Memoirs of Jahangir, trans. Wheeler M. Thackston (Oxford: Oxford University Press, 1999), 83. August 17, 1608.

${ }^{126}$ Ibid, 303. Apr 22, 1619.

127 Jahangir, Emperor, Tuzuk-iJanagiri-Jahangirnama: Memoirs of Jahangir. trans. Wheeler M. Thackston (Oxford: Oxford University Press, 1999), 303. March 1607-March 1608.
} 
antelopes in just one day. Even though Jahangir's excess in hunting seems lavish and unrestrained, he did however hope that "after attaining to the age of fifty, I would never more make use of a fowling-piece."128 Unlike British and Indian men, Jahangir was unconcerned with dwindling stocks of animals since game was quite plentiful during his reign. Instead, after shooting an antelope with the aforementioned fowling piece, Jahangir went in a state of unconsciousness because its death made an impression and it dawned on him that he was killed a living thing. It was there that he made a promise to himself he would not use fowling pieces to shoot game.

The skins of wild animals were also used to denigrate individuals. Jahangir's son Khusrau was dressed up in the skin of a black-coloured ass and was taken around the town of Lahore. ${ }^{129}$ Khusrau, was responsible for endeavoring to assume power over Jahangir's throne and was formally kept imprisoned because of his wicked deeds. The exact opposite was true for the Mughal Emperor; that is the power over wild animals symbolized the essence of his manliness. Courage, strength, and masculine prowess were prized by Jahangir and he rewarded these traits generously. Mirza Mahmoud decapitated a lion and received the title of Sheir be dou-neim or lion halver because he used a sword to subdue the lion. A use of a man's power was highly prized in the Mughal world as it displayed his strength and of course his masculine prowess. ${ }^{130}$

Anytime a large wild animal was killed, it was recorded as an important event.

\footnotetext{
${ }^{128}$ Ibid, 60.

${ }^{129} \mathrm{Ibid}, 81$.

${ }^{130} \mathrm{Ibid}, 93$.
} 
For example, in the Shah Jahan Nama the important feat of killing a lion with simply a sword at hand was recorded as a particularly noble and honorable action that displayed the strength and prowess of Shah Jahan during the fifth year of his reign in 1632. The vast amount of game that the Emperor Shah Jahan killed on his expeditions also represented his great manliness. While hunting in Palam near Delhi, he shot forty black bucks in four days all "of which he brought down at the first shot."131 He used guns instead of the sword that was reserved for the lion. Nevertheless, it was a grand feat that multitudes of game were shot down, especially at the first shot, since it upheld his sportsmanship as a great marksman. Shah Jahan Nama is further littered with the great exploits of Shah Jahan's hunting “bag." The Royal Librarian accounts how Shah Jahan killed "two lions, 20 nilgaos, and 60 deer" in an eight day period at Bari, which was the location of his hunting retreat in Rajasthan. ${ }^{132}$ Shah Jahan often left his military expeditions to seek out hunting. For example, during his campaign against Jujhar Singh in 1628 , he went to Gwalior to hunt. ${ }^{133}$

In some instances, the Mughals employed men to perform the duties of driving game to an enclosure. To celebrate the holiday of Id al-Qurban (Eid al-Adha), Shah Jahan ordered chital hunting at Bhimbal where 5,000 men were employed to drive the game to the hills. ${ }^{134}$ Men who accompanied Shah Jahan also killed some of the chital or

\footnotetext{
${ }^{131}$ Inayat Khan, The Shah Jahan Nama, ed. Z. A. Desai and W. E. Begley (Delhi: Oxford University Press, 1990), 122.

${ }^{132}$ Ibid, 211.

${ }^{133}$ Khan, Shah Jahan Nama. 28.

${ }^{134}$ Ibid, 124.
} 
spotted deer. Similar enclosures called qamargahs were used to hunt certain animals. Qamargahs offered the Emperor, princes, and royal grandees wonderful opportunities for hunting to their heart's content. Qamargahs did not always involve driving game to a particular location, but instead locations were designated as qamargahs when information was discovered about the congregation of many wild animals. In one instance, the Chief Huntsman or Qarawal Beg, whose name was Allah Wirdi Khan discovered that onagers came to a specific location to drink water. After this information was proved to be true, the animals were blockaded into an enclosure and royal grandees invited to the subsequent hunting expedition. Shah Jahan hunted onagers, also called wild Indian asses in Bhera, which was a pargana or district of Punjab. There he killed twenty onagers, always more than his sons and other grandees as their number came up to forty-three only. ${ }^{135}$ Shah Jahan was also the Emperor who reputedly had killed the largest number of game in a single day (as he killed 52 deer). ${ }^{136}$ Thus, the multitudes of game killed by the hands of Shah Jahan was partly a symbolic act, intended to displayed his manliness and power over his subjects and reinforced his place on the top of the Mughal hierarchy.

While a degree of excess typically marked the Mughal Emperors in terms of the sport of hunting, they could also display a sense of restraint, even though that restraint was far lower than today's standards or even the standards in the $20^{\text {th }}$ century. Shah Jahan, on one occasion, for example, displayed the trait of benevolence and a concern for animals as he allowed 1,700 black buck and deer to go free after shooting 300 game from

\footnotetext{
${ }^{135}$ Ibid, 141.

${ }^{136}$ Ibid, 247.
} 
a total of 2,000 enclosed in a qamargah. ${ }^{137}$

In addition to a Qarawal Beg there was also a Mir Shikaran or Master of Hunting employed in the Mughal kingdom. This Master of Hunting usually oversaw the buying of trained hawks. ${ }^{138}$ Mughal traditions of hunting also included the sport of hawking. Hawking was a process where horsemen took hawks and let them loose on herons. These hawks were specially trained to hunt herons. The hawks would eventually devour the herons. The men on horseback also beat drums to ensure that the herons would not escape the mouths of the hawks. Hawking was typically not an activity that the Emperor engaged in, however other Mughals of a lower rank enjoyed the sport of hunting with hawks.

Several scenes in art depict the manliness of Mughal Emperors. Some of the most renowned depictions of the Mughals in hunting sceneries are housed in the Royal Library in Windsor Castle. One such rendition has Shah Jahan with a halo around his head holding a sword and killing a lion who is attacking a man that has fallen to the ground. Shah Jahan with a halo around his head represents a glorious man who not only saved the fallen man, but used his might and power to kill the deadly beast. ${ }^{139}$ Shah Jahan's face shows he displays no fear of the beast, but instead has him calmly depicted in a royal manner. He is also dressed in typical Mughal garb and does not possess a gun at hand.

\footnotetext{
137 Ibid, 265.

138 Ibid, 244.

${ }^{139}$ Shah Jahan Hunting a Lion with Jahangir. 1640. Windsor Castle, Royal Library (Padshah Nama, fol. 135v).
} 
Mughal hunting scenes would later be followed by Indian renditions of hunting scenes that were embroidered by Indian court women. One such example depicts men on horseback with bows and arrows and swords and guns shooting a tiger, sambar, a female lion, and antelope. ${ }^{140}$ This cloth cover is similar to Mughal designs that capture hunters and animals galloping in motion.

\section{Princely Rulers}

Princely rulers including Nawabs and Maharajas would succeed the ailing and eventually the fallen Mughal Empire. They established successor states where they presided as rulers of their own kingdoms. The Nawabs, or successors to the Mughals, also enjoyed hunting as it was almost an obsession for them. The Nawab was essentially a governor of a province of the Mughal Emperor, or a Muslim ruler of a state who also acted as faujdar or enforcer of criminal law in his state. In many cases, Nawabs were also challengers to Mughal rule. The Nawab of Hyderabad rode on an elephant on his way to Lucknow and shot wild animals along the way. He bagged four partridges and antelopes in $1795 .{ }^{141}$ The maharajas similarly used Mughal techniques of hunting whenever they held a hunting event for the British. The maharajas were different from Nawabs in that they were typically Hindu rulers who referred to themselves as great princes. Enclosures were formed where animals such as deer were driven together to facilitate easy hunting for the eminent people who were to attend the event. Humayun, the son of the Mughal

\footnotetext{
${ }^{140}$ Ceremonial Cover with Hunting Scene. $19^{\text {th }}$ century. Philadelphia Museum of Art.

${ }^{141}$ News-letters, 1767-1799 (Nawab Mir Nizam Ali Khan's reign), Ed. Yusuf Hussain (Hyderabad: Central Records Office, 1955), 38.
} 
Emperor Babur in his Memoirs records one such enclosure full of deer. ${ }^{142}$ This was considered staged by many British sportsmen.

Indian princely rulers emulated the Mughals and engaged in shikar. The Nawab of Hyderabad was recorded bagging game on the $14^{\text {th }}$ of June in $1797 .{ }^{143}$ Hunting was also ordered by the Nawab of Hyderabad. Imamuddin Khan for example reported to the Nawab that five wolves and seven foxes were spotted in the forest. So, the Nawab ordered that Roshan Khan go out and shoot them. ${ }^{144}$ Unlike the British who instantly killed the animals when news was reported to them about the whereabouts of wild game, princely rulers had others shoot the animals for them.

Indian princely rulers also engaged in what the British referred to as "native brutality" mainly because it was not a form of sport as defined by the British. Nawab Saadat Ali Khan watched a wild animal fight between wild buffaloes and a tiger. ${ }^{145}$ This was a form of entertainment for the natives as well as for the Nawab. During the wild animal fight, the tiger escaped out of the canopy. However one of the Nawab's men struck the tiger with a sword. Sarfarazud-daula therefore displayed great masculine prowess in the great feat of what the news-writer terms burning "[the tiger's mouth] with a rocket." ${ }^{\prime \prime 66}$ The unsportsmanlike physical attack on the animal would have been viewed

\footnotetext{
142 Jouhar, Tezkereh Al Vakiat, or Private Memoirs of the Moghul Emperor Humayun, 71.

143 News-letters, 1767-1799, 48.

144 Ibid, 38.

145 Interestingly, animal fights also occurred in $19^{\text {th }}$ century Britain. They were termed 'blood sports' and included cockfighting, dogfighting, bear-baiting, badger-baiting, and bull-baiting but were generally enjoyed among the working-class.

146 News-letters, 1767-1799, 53.
} 
by the British as cruel and not be categorized as hunting, yet the princely rulers believed that wild animal fights was genuine shikar. Not only did he do his duty and protect the Nawab, but also the ladies and other men who were present. Like British hunting events, ladies were present at the wild animal fights.

\section{$18^{\text {th }}$ Century India}

In contrast to the 19th and 20th centuries, there are relatively few records of sport in colonial India in the 18th century. The primary reason for this is that records of sport multiply exponentially in the 19th century in Britain and this phenomenon is mimicked in British India. Sport was not quite as much of an obsession in the 18th century as it was in the 19th and 20th centuries, mainly because the British were primarily busy fighting numerous wars and trade and politics were of prime importance. Hunting was a leisurely exercise and a way for Britons to immerse themselves in the bounties of game that the Indian subcontinent provided. It is evident from the sources that British male hunters or sahibs were awestruck with the "free" game that India had to offer and took full advantage of unrestrained shikar or hunting in the subcontinent because there were no regulatory constraints on hunting as in the metropole. British sahibs were also participants of lavish hunts by the Nawabs of India, which helped them forge and build an alliance with the Indian ruling elite and brought them in association with pre-existing elite Indian rulers. It also led to the British imposing restraints, etiquette, and a nascent ecological awareness, all of which developed more in the $19^{\text {th }}$ and $20^{\text {th }}$ centuries but began in the $18^{\text {th }}$ century. 


\section{The British Encounter with Indian hunting in the $18^{\text {th }}$ century}

In the $18^{\text {th }}$ century, there was an increasing curiosity and interest in Indian methods of hunting among British sportsmen in colonial India. Bernard Cohn's Colonialism and its forms of knowledge argues that the knowledge of Indian traditions and institutions was crucial in carrying out the East India Company's commercial endeavors and in establishing the notion of British power. Cohn traces the acquisition of knowledge from the works of $17^{\text {th }}$ and $18^{\text {th }}$ century Orientalist scholars. Knowledge of Indian languages was instrumental in forging power. ${ }^{147}$ Initially, the British were dependent on munshis (scribes), banians (moneylenders), vakils (judges), Brahman pandits (priests) and others familiar with court formalities and legal procedures to act as mediators to Mughal royals for company affairs. Soon European interest empowered Oriental scholars to acquire a command of Persian and Sanskrit, the languages of the courts and ancient sacred texts, respectively. N.B. Halhed, for example, began to produce grammars and dictionaries of the classical and vernacular language. Fort William College was established in 1800 under Lord Wellesley in order to support further understanding of Indian traditions and customs.

The curiosity about Indian languages and customs led to an interest in indigenous hunting methods. While information on regal hunting tends to be in the historical record, there was also hunting by tribals and Indian Muslims which is minimally recorded in published accounts of sporting books. Non-traditional hunting methods were devised for capturing game. Fowlers tended to be Muslims since Hindus typically believed in the

${ }^{147}$ Bernard Cohn, Colonialism and its forms of knowledge, 16. 
principle of ahimsa or non-violence and abstained from taking the life of animals.

Captain William Sympson, for example, discusses how he viewed the killing of ducks by a Muslim man. He writes that the "Fowler puts his Head into a wooden vessel, which has Holes in it for him to see and breathe, and is all cover'd over with Feathers of such Birds as [are in] the Place with that one his Head he goes into the water, [...and] draws them under water." 148 The subdued bird was then captured by the Fowler. Sometimes such men would be employed by Nawabs for the purposes of catching game. As Blane, an observer in India noted contraptions like nets and snares were often used for hunting.

It is noteworthy that British hunting had a strong similarity to Indian traditions of hunting. The nature of hunting in Britain was that it was an aristocratic sport where elites generally hunted small game birds and deer. The bounty of game present in India in the absence of hunting laws was a strong force that drew Britons into the hunting arena in India. In India, elites hunted as well, although there was also a tradition of tribal hunting for which there are no records. Once the British arrived in India they formed a union with Indian elites such as Nawabs and the British began to employ these Indian elite traditions to hunt. This social bridge between the British and the Indians is actually formed in the $18^{\text {th }}$ century. Lynn Zastoupil has stated that early colonial rule tended to be flexible and power was often negotiated. In fact, he states there was no "universal essence" and boundaries were often blurred. ${ }^{149}$ Indian hunting was like English hunting, only it was conducted with no constraints apart from one's own moral conscience, and it

\footnotetext{
${ }^{148}$ Capt. William Sympson, A New Voyage to the East Indies viz. to Suratte, and the coast of Arabia... (London: H. Meere, 1715), 40.

${ }^{149}$ Lynn Zastoupil, "Intimacy and Colonial Knowledge," Journal of Colonialism and Colonial History, 3, 2 (2002): 1 .
} 
was more elaborate, and even more aristocratic than English hunting.

Apparently the British began to hunt in India out of sheer boredom. Men who fought in the military for the East India Company often hunted while they were traveling to another destination. A passage from Captain Little's accounts of the fight against Tipu Sultan shows how hunting was often a sideshow for soldiers. India was described as teeming in foxes, hares, partridges and jackals. ${ }^{150}$ There was no limit to how much game soldiers could get because of the absence of hunting laws, acts and licenses.

Therefore, firearms were not only used against invading armies but against wildlife as well. Similar to British foxhunting where dogs were used to hunt and catch foxes, hounds such as greyhounds were also employed in India where British men kept them. In the $19^{\text {th }}$ century shooting also continued by men while on active duty in the military.

When invited to a regal hunt, most British participants were impressed and awestruck with the power of the Nawab as well as his hunting skills. This is one of the main points in British hunter accounts. L.F. Smith writing in July of 1797 to another Briton in Calcutta expresses this viewpoint as he states "His Excellency is one of the best marksmen I ever saw [...] as one day with another he fired above 100 shots at every species of birds and animals."151 Smith praised the Nawab's shooting skills as good marksmanship and also as the mark of a refined gentleman, and this was highly

\footnotetext{
${ }^{150}$ Anon, “A Narrative of the Operations of Captain Little’s Detachment, and of the Mahratta Army, commanded by Purseram Bhow; during the late Confederacy in India, against the Nawab Tippoo Sultan Bahadur." The Critical Review, or Annals of Literature (September 1794): 1-6.

${ }^{151}$ L.F. Smith, "Description of a hunting part in India, A letter from a gentleman at Calcutta," Scots Magazine, July 1797: 449.
} 
favored. This quote also highlights the awe that Smith felt as he describes the Nawab's lavish style of hunting with no restraint on numbers. Shooting excessive game was seen to be a luxury and one fit for elites. In Britain in the $18^{\text {th }}$ century, hunting was not excessive of unregulated. In India there was clearly no sense of any need to preserve dividing stocks of game. This also marks India off as distinct from "civilized" Europe and was a sign of Oriental "despotism." The idea of preservation and the introduction of conservation measures was not yet seen in the $18^{\text {th }}$ century, as shooting was rampant and unrestrained.

These accounts challenge earlier scholarship by Guha and Guha in This Fissured Land who argue that pre-colonial rulers' practices were ecologically sound and sustainable. For Guha and Guha, "British colonial rule marks a crucial watershed in the ecological history of India. The country's encounter with a technologically advanced and dynamic culture gave rise to profound dislocations at various levels of Indian society."152 In fact, a thorough overview of hunting during the time of the Nawabs shows that they were no more ecologically conscious than the British who hunted in India throughout their military service with no closed seasons as there were in Britain. The excess in regal hunts can be ascertained from the account of hunting experiences published by British hunters. L.F. Smith wrote that hunters in his party fired over 10,000 shots to kill 170 elephants. 200 shots would have easily killed the elephants however the excess represented the Nawab's power as well as a lack of hunting etiquette present in India. Customarily in Britain etiquette demanded that animals were not executed with

\footnotetext{
152 Madhav Gadgil and RanajitGuha, This Fissured Land (Oxford: Oxford University Press, 1992), 5.
} 
rounds and rounds of bullets.

The hunt also displayed the power of the Nawab and the subservience of his subsidiaries. Hunting was an arena where Indian rulers could legitimize their rule over their kingdoms by displaying their aristocratic omnipotence as well as their stature in the community. The Nawab, Smith writes "perceiving it to be impossible to catch him [a wild animal] ordered his death and immediately a volley of above 100 shots were fired."153 Smith is referring to a wild animal and the Nawab's power over its life or its death. This decision could only be made by the Nawab and translated to his power over nature.

\section{Forging an Alliance with the Indian ruling elite}

The British hunted both alone and in the company of others in India. Indian hospitality was key to the display of a regal hunt. The Nawab typically was accompanied by his entourage as well as gentleman of the court along with distinguished guests. The British emulated the practices of Indian Nawabs in their manner of excess shooting of game, reminiscent of Oriental despotism, however they were not able to engage in the elite activity of big game hunting with such style, unless they had the auspices of a grandee. For example, L.F. Smith writes of his hunting experience as he states of the game killed: "eight tigers, six elephants, and caught twenty-one. To enumerate the other kinds of game would require a sheet as ample as the petition which was presented to

153 Ibid, 450. 
Junggaze Khan." ${ }^{154}$ L.F. Smith's bag of animals caught represents the British emulating Oriental excess and jumping into the "free" game as well as money which could be made in India. In a short hunting trip, several animals were killed. Elephants that were caught could fetch a price of Rs. 50,000 and therefore hunting was another outlet where money could be made in India for British men. Smith states that the money was not his objective, but sport was, however profits was on the minds of other Britons in India.

The regal hunt showcased the British and Indian triumph over Indian wildlife as the grandness of the hunt was evident in its numbers. Large numbers of Indian servants and beaters whose job was to beat the dense foliage back were employed in the hunt. Shikaris (native hunters) and soldiers often accompanied the hunt. Therefore, hunting was limited to simply pulling a trigger for most Britons as the bulk of the work (tracking game, beating) was already done by Indian subordinates. For example, one hunt that bagged 170 elephants employed 1,200 mahouts or elephant drivers. The unevenness often meant that humans had a distinct advantage over wildlife because of the sheer numbers involved and employed by the Nawab. Regal hunts also displayed a sheer sense of excess as numerous game could be killed with the help of so many servants. The display of excess also occurred in other areas of the Nawab's court. In a sense, it was a reflection of a wider set of cultural practices that were part of Indian princely rule.

British accounts of Indian sport discuss hunting or participating in a hunting event as a spectator with a member of the ruling class such as a Vizier or other Mughal

\footnotetext{
${ }^{154}$ L.F. Smith, "Description of a hunting part in India, A letter from a gentleman at Calcutta," Scots Magazine, July 1797, 452.
} 
elite. The British when invited to hunting events by Nawabs or Nabobs as they were called by the British, often brought their own tent to stay at the camp site along with bullocks, or camels to carry their luggage. Unlike in Britain, there were no inns and this caused a bit of trouble for British sportsmen. Camels and bullocks along with elephants were a common form of transportation to various hunting destinations. Nawabs displayed their hospitality and power to British men by having them accompany their grand hunts. Nawabs had several coolies, cooks, and beaters under their command along with "nautch" girls or dancing girls. These servants would make sure that British guests were well attended to in all their needs and "nautch" girls provided amusing entertainments as well. Unlike the 20th century, which saw the preeminence of guns in the hunting arena, a wide variety of weapons were carried. English pistols, bows and arrows, nets, swords and daggers are some of the mentioned weapons that were used to kill the game. ${ }^{155}$ Hawks were also used to catch other game and cheetahs were also used to catch deer like chital (spotted deer).

Tiger hunting remained supreme among Nawabs. William Blane writes that "When intelligence is brought of a tiger, it is matter of great joy, as that is considered as the principal sport, and all the rest only occasional to fill up the time." 156 Nawabs usually hunted tigers by surrounding them with a line of elephants to prevent the tigers from escaping. The tiger then became an easy target for the Nawab. This was a simplified method of hunting that did not require much physical prowess from the shooter,

\footnotetext{
155 Unknown, “Manner of Hunting in India," Town and Country Magazine, August 1787: 342.

156 William Blane, "An Account of the Hunting Excursions of Asoph ul-Doulah, Vizier of the Mughal Empire, and Nabob of Oude, who attended these excursions in 1785 and 1786," The Edinburgh Magazine, or Literary Miscellany, March 1788: 157.
} 
especially since the locating and tracking of the tiger as well as the beating back of dense forests was the work of the servants. Nevertheless, the tiger was typically viewed as the raja of the jungle, and hunting the tiger, regardless of the method employed, signified the physical prowess of the hunter. The Mughals also believed that the larger beast that the hunter pursued, the greater the hunter's prowess. Blane also states that the Nawab typically shot first since he was the one who organized and paid for the hunt so this meant that if the Nawab killed the tiger then he would be seen as the 'great and mighty one.' Tiger hunting became one of the most important sports in the $19^{\text {th }}$ and $20^{\text {th }}$ centuries among British sportsmen because of the dangers involved. Sramek has noted, the British thought that the successful tiger hunt showed that they matched the Mughals as hunters and implicitly as legitimate rulers of India. ${ }^{157}$

The politics of hunting often allowed for diplomacy between two different cultural groups. The Nawab that Blane was referring to was Asaf ud-daula (1775-1799), who according to Natasha Eaton owed the Company debts as an artist had painted a portrait of him, and was not someone who wished to cater to British demands. Asaf uddaula preferred to have a Mughal rendition of himself emphasizing his identity as an Indian. Nevertheless, he ended up inviting British officials to his palace perhaps because the British were forming a formidable stronghold around the turn of the century. ${ }^{158}$

157 Joseph Sramek, “"Face him like a Briton': Tiger Hunting, Imperialism, and British Masculinity” in Colonial India, 1800-1875," Victorian Studies 48, 4 (Summer 2006): 661.

158 Natasha Eaton, "Between Mimesis and Alterity: Art, Gift, and Diplomacy in Colonial India, 1770-1800," Comparative Studies in Society and History 46(4) October 2004: 833-834. 
Hunting was another arena in which Asaf ud-daula could express his own lifestyle choices, but still negotiate and forge diplomacy with the British.

\section{The development of etiquette and ecological awareness}

My last argument for this chapter is about the development of etiquette and a sense of ecological awareness in the hunting field. This can be seen in Douglas Reid's "Beasts and Brutes: popular blood sports, c. 1780-1860" as well and is part of the character of British hunting. Reid states that hunting was an important facet of Victorian Britain's culture. There was a steady progression towards civilized hunting with marked etiquette and tradition in contrast to blood sports of the working class that were castigated as malicious, brutal and inhumane throughout the later course of the $19^{\text {th }}$ century. In contrast to hunting in Britain which was becoming more "humane," the British encounter with hunting in India led to emulating hunting practices that were excessive. There are no known tensions or debates about the differences in accepted hunting practices. The $18^{\text {th }}$ century marked the development of a sense of etiquette arising in the history of hunting. By the $19^{\text {th }}$ century blood sports were deemed to be cruel and painful to the animal..$^{159}$ The definition of sport evolved to one of a hunter as a refined gentleman who used time honored techniques and did not inflict great pain in their prey. The shift towards refined hunting largely occurred in the $19^{\text {th }}$ century, however its origins and precedents began to be seen in the $18^{\text {th }}$ century, both in England and in colonial India.

\footnotetext{
159 Douglas Reid, "Beasts and Brutes: popular blood sports, c. 1780-1860" in Sport and the working class in Britain ed. Richard Holt (Manchester: Manchester University Press, 1990), 17.
} 
Unlike India where both the majority of Britons and Indians indulged in hunting without foreseeing the consequences of their hunting activities in Britain there was a growing tide of lobbyists against cruelty towards animals. In the $18^{\text {th }}$ century, there was growing resentment against cruelty towards animals. This was part of the influence of Enlightenment philosophy, which emphasized the importance of rational thinking. JeanJacques Rousseau highlighted the salience of natural laws or the innate laws dealing with nature. Authors of novels as well as other liberal men of the pen categorized all hunting as cruelty towards animals. Many sportsmen vigorously defended the sport of hunting from the attack by liberals by adding to the debate arguments in support of hunting. One such account from a liberal man attacking hunting came in The hare, or hunting incompatible with humanity." The dialogue is written in third person as a hare and it expresses the innocence and defenselessness of the hare at the hands of the merciless hunters. This work was written for young men to open their eyes against ill treatment of hares by the "sport" of hunting. ${ }^{160}$ The symbolic nature of this piece is that most sportsman referred to the hare as cunning, stupid and senseless.

Even though there was no forethought of the possible extinction of these animals among British and Indian sportsmen, there was an underlying distaste for the killing of animals from British sportsmen. The feeling of remorse, guilt and sorrow was expressed in a sportsman's account of a hunting event. L.F. Smith writes of the shooting and hatchet attack of an elephant and the suffering the animal faced as he states "I could not at this time refrain from pitying so noble an animal, I saw in him the great Epaminondas

\footnotetext{
160 John Gough, The hare, or hunting incompatible with humanity written as a stimulus to youth towards proper treatment of Animals (London: 1799).
} 
incompassed $[\mathrm{sic}]$ by the Lacedomonians, at the battle of Mantineia [...] horsemen and soldiers with barbaric insult began a cruel and degrading assault the fight was very affecting; he still breathed and breathed with a groan; he rolled his eyes with anguish."161 The aforementioned passage reflects the barbaric nature of numerous men attacking a single animal and it also reflects the author's remorse and empathy for the animal. The sight was riveting and depressing at the same time. For Smith, what made this "hunt" different from the others was the use of hatchets that brutally inflicted pain, unnecessary suffering and a great deal of blood loss. It was a tragedy similar to a monumental tragedy during Greek times. The lack of moans, yells and other sounds showed that the elephant was bravely fighting the attack in spirit and this made it even more personal and touching for the sportsman. Smith however states that like many great Greek and Roman men, who were overpowered by their enemies, death was sadly their fate. This is a statement of acceptance of the status quo of the "butchering" of animals. Smith's account is one of the few emotional accounts against hunting, albeit a cruel version of hunting, and it is very distinguished from other hunters in Britain who scarcely bothered to discuss the sufferings that the animals they shot went through.

Thomas Williamson also describes the beginning of the decline of game in India. Nevertheless, he did not attribute the cause of the decline to himself or by extension other sportsmen, but was aware of the steady decline of game and the loss of habitat. Agriculture for sportsmen was the culprit. There was a great lament for the decrease of game, as the activities of the sportsman depended on a steady flow of game. The author

${ }^{161}$ L.F. Smith, "Description of a hunting part in India, A letter from a gentleman at Calcutta," Scots Magazine, July 1797, 450. 
discusses declines of hog deer and grey partridges as he writes: "the west bank of the Ganges from Sooty up to Bar, was famous for hog deer. In the space of ten years such numbers had been settled and such vast quantities of land brought into cultivation, that a brother sportsman riding over fields with me [noticed how] only a few grey partridge could be found and said "they have ruined this district."162 The lack of game was lamentable because the district that Williamson and his associate were referring to was now not of any use to them as sportsmen.

The above passage comes from Thomas Williamson's Oriental Field Sports published in 1807 in London, which was one of the seminal and earliest published books on hunting. This book was commonly referenced in sportsman's books of the $19^{\text {th }}$ century. Oriental Field Sports is a seminal work because it began and marked the rise of the genre of sporting books in India. One of the main differences between Smith's account of a hunt and Williamson's Oriental Field Sports is that the latter emphasized natural history. The $18^{\text {th }}$ century saw a great interest in curiosities and the study of animals. Gentlemen took a profound interest in natural history as it helped propagate them into well-rounded, cultured individuals.

Captain Thomas Williamson published this account to give tips to novice hunters. These tips generally consisted of guidelines on where to locate game. Williamson writes that cultivated fields are a good lookout spot for game because they generally hide around fields that are close by to a forest or jungle where they can eat the crops. The author's tips became standardized for future British sportsmen. He writes that one should strive to do

\footnotetext{
162 Thomas Williamson, Oriental Field Sports (London: Edward Orme, 1808), 140.
} 
the following: "The dress and appearance of a native should be imitated" in order to fit in the environment. ${ }^{163}$ Khakis would be generally used when hunting in the $19^{\text {th }}$ and $20^{\text {th }}$ centuries to fit into the atmosphere and not attract the attention of any wild animal. These tips became customary etiquette for later sportsmen.

Part of hunting etiquette was a differentiation in hunting methods from the lower orders who are typically described as "poachers.” Like Smith, Williamson also described the customs of Indian hunters perhaps because he found them interesting or because he wanted to record their hunting methods for posterity purposes. Williamson describes Indian hunters "who hunted hog deer with nets stretched across grass plains, and on jungles."164 These were quite unconventional methods that were used by indigenous tribal hunters such as the Bhils or Gonds. Springs were also used to hunt animals. These springs were attached to yards of string and affixed into the ground with sticks. Unlike later British sportsmen in the late $19^{\text {th }}$ century who tried to legitimize their position as the sole hunters of India, while denouncing Indians as "poachers" mainly because of their lack of hunting etiquette, viz. the use of a gun, Williamson compares Indian hunters to British poachers, but does not de-legitimize their traditional hunting methods. He does, however, make it clear in his book that he does not use these methods to hunt thereby differentiating himself from the "poachers."

Poachers in England commonly used such methods and devices like springs in order to get game. The author does not denigrate Indian hunters for not using a gun. By the $20^{\text {th }}$ century, however, the lack of a gun for use of hunting made one a poacher and

\footnotetext{
${ }^{163}$ Captain Thomas Williamson, Oriental Field Sports (London: Orme, 1807), 142.

${ }^{164}$ Ibid, 72.
} 
unworthy of the title of sportsman. As Anne McClintock writes in Imperial Leather: Race, Gender and Sexuality in the Colonial Contest, there was a shift from "scientific racism" to "commodity racism" where Indians and other colonial subjects could be reformed by adopting the correct commodities. ${ }^{165}$ The lack of proper commodities, however, was a sign of inferiority, and resulted in racism towards colonial subjects. If one used a gun instead of a rock, one could certainly be considered a civilized, gentlemanly hunter. British hunters viewed men who threw rocks at animals unsportsmanlike.

In stark contrast to the number of game killed by Nawabs, gentry in England killed far fewer game. Peter Beckford writes how a friend of his "killed 37 brace of foxes in one season."166 While this seems unusually high, when compared to the numbers hunted by Nawabs, these numbers are quite modest. We do not have an accurate number or records of how many game tribals killed, but we do know that they used all the meat and hides of the animals they killed thus never using more than they really needed. A tiger a day for the Nawab with no closing season amounts to much more than the foxes killed during foxhunting season in Britain.

Hunting or shikar was a way for ruling elite in India to work in collaboration together to dominate the Indian environment. British male hunters or sahibs were awestruck with the "free" game in the absence of trespassing laws, game acts, licenses and reserved forests. The Nawab's word gave the British the right to hunt with the

\footnotetext{
165 Anne McClintock, Imperial Leather: Race, Gender and Sexuality in the Colonial Contest (New York: Routledge, 1995), 35.

166 Peter Beckford, Thoughts on Hunting (London: D. Bremner 1798), 28.
} 
Nawab's party. Hunting helped establish Britons as elites in colonial India and linked them with the Nawabs.

In the $18^{\text {th }}$ century in Britain, sportsmen devised a code of conduct for hunters that served as a written system of proper etiquette. British sportsmen essentially wrote manuals on how to properly hunt for gentlemanly sportsmen. This code was evident among British hunters' accounts in colonial India and was further expanded by British hunters in the subcontinent during the turn of the century. British sportsmen both in England and in India displayed a nascent sense of ecological awareness as they described the decline of game. Both Britons in India and those in Britain lamented the steady change in society that led to the decline of game. The $18^{\text {th }}$ century served as a great precedent for the foundation of restraint, etiquette, and ecological awareness in gentlemanly hunting seen later in the British India and Britain. The regal hunt of the $18^{\text {th }}$ century also served as stepping stone for the British to mingle with Indian ruling elites and establish their place in the ruling hierarchy.

\section{Conclusion}

This chapter has presented an overview of hunting in pre-colonial India as well as during the $18^{\text {th }}$ century. References to hunting are quite sparse during the Vedic Age. Mughal hunting displayed excess and also restraint. Hunting was the privilege of the royal princes and those invited to partake in the hunting process. Hunting for the Mughals was a symbolic representation of the power of the head of state. While hunting for the early Mughals displayed the ability to wield a sword against game, by the late Mughal 
dynasties, guns were appropriated as common hunting weapons. The British encounter with hunting in India in the $18^{\text {th }}$ century reveals how the British often hunted side by side with royal Indian elites who more often than not, had no sense of restraint and displayed the very Oriental sense of unbridled excess. These practices were features of Indian hunting that the British would strive to change and eliminate in the subsequent centuries. The $18^{\text {th }}$ century also resulted in the crystallization of hunting etiquette. The main goal of this chapter was to introduce the distinct style of Indian hunting and the contrasting style of British hunting in India that saw the development of etiquette fit for a gentleman hunter. In the $18^{\text {th }}$ century, there is no defined Anglo-Indian tradition of hunting. The following chapters look specifically at British hunting practices especially and the change from the $19^{\text {th }}$ to $20^{\text {th }}$ centuries. The subsequent chapters will show how distinctively Indian styles of hunting along with some British traditions became incorporated into the Anglo-Indian hunting practice.

\section{Chapter 3: Shikar: the Regal sport of the Sahibs and Maharajas in colonial India, 1800-1899.}

This chapter examines the processes by which hunting became institutionalized as 
an elite sport by British sportsmen and Indian Maharajas, especially by the 1890s.

Simultaneously, non-elite hunting increasingly became categorized as poaching or unsportsmanlike. This was a construction that legitimized the British severing the mantle of control from the Mughals. This chapter delves into the reasons for hunting which includes lonelineness, boredom, the display of masculinity, imperialism and paternalism. Despite British sportsmen's braveness, they were always reliant on Indians both for collaboration and assistance in the hunting process. Despite their necessity of local collaborators, the British created an ideology of differentiation that emphasized the Indians' lack of etiquette and poacher-like qualities. The imperial regal hunt was a byproduct of this differentiation and was standardized from the conglomeration of hunting etiquette, hunt clubs and regal forms of hunting in India during the $19^{\text {th }}$ century. The Anglo-Indian hunting style was a hybrid or fusion of British and Indian practices. A nascent ecological awareness was also present among a few select sportsmen during the late $19^{\text {th }}$ century.

Hunting was one of the most popular sports during the $19^{\text {th }}$ century and the favorite pass-time for British residents. ${ }^{167}$ Indian leisure revolved around big game hunting in select forested or fringe areas of the Indian subcontinent. Frontier areas like Burma, Nepal, and Ladakh served as abundant grounds of game. Generally, East India

167 John MacKenzie, The Empire of Nature: Hunting, Conservation and British Imperialism (Manchester: Manchester University Press, 1988), 25. 
Company military officials and later British Indian officials would engage in hunting wild game in these frontier regions. Other areas of India also offered plentiful game shooting opportunities. Anglo-Indians engaged in hunting animals in such areas as Kashmir, Bengal, Uttar Pradesh, the northwest and the Madras Presidency. Wild game differed according to the different regions. Tiger, lion, duck, deer, pheasant, nilgai (blue bull), elephant, bear, peacock, wild pig hunting were all undertaken in India.

\section{A model hunt}

Hunting as a recreational sport differed depending on the sportsmen involved.

Generally speaking every sportsmen had a shikari or native hunter and employed several coolies and servants both to cook their food and accompany them on their hunting expeditions. Recreational hunting usually was not a grand activity, but did include a significant number of beaters who beat back the dense forest foliage particularly if the sportsmen was in Assam or in the Nepalese Terai. Beaters were also employed in jungles where dangerous game were found. Bearers often carried the sportsman's luggage including furniture, washbasin, bedding, dinnerware, utensils and foodstuffs. Their loads could reach up to 80 pounds. Bullock carts and camels were sometimes used to transport goods to the hunting destination. Shikaris served as guides and trackers for the British and were assistants to the hunt, often carrying the sportsman's guns. The shikari was often the first person to hear khabbar or news by villagers of depredations committed by wildlife and this information was relayed to the sportsman. Sportsmen's accounts state 
that the salaries for shikaris ranged between Rs. 20 and Rs. 35 per month. Rasad or a subsistence allowance was also added which typically was Rs. 5. This money could be used for buying clothes or for food expenses. Rs. 3 was typically given to a coolie as rasad.

\section{Reasons for hunting in colonial India}

Prior to the 1890 s, hunting was deemed to be a necessity for British residents in India. Only Europeans engaged in this random shooting, otherwise known as hunting of animals for sport. This was not the regal hunt practiced by Indian rajas. The AngloIndians who settled in India were a small community. Recreation in India was limited to activities that went on in the mofussil or district. Social gatherings were limited. As Major Blayne Walshe put it: "I don't know what we should have done with ourselves had it not been for our shooting."168 The monotonous activities associated with the military were only one more reason to engage in hunting. Shooting occurred while military officials were on duty. Lieutenant Pollok stated that "All my shooting I got whilst employed on duty; had I been an idle man I could have slain ten times what I did."169 From this statement, we can assume that hunting was largely undertaken out of boredom and possible loneliness, rather than out of a concerted Orientalist effort to know and emulate

\footnotetext{
168 Blayney Townly Walshe, Sporting and military adventures in Nepaul and the Himalayas. A narrative of personal encounters and narrow escapes (London: J. Blackwood \& Co., 1875), 35.

${ }^{169}$ Lieutenant-Colonel Fitz William Thomas Pollok, Sport in British Burmah, Assam, and the Cossyah and Jyntiah hills...(London: Chapman \& Hall, 1879), 30.
} 
Indian rajas. Hunting was also a popular recreation for the summer months especially in Srinagar and Simla. The favorable climate in Kashmir was an impetus for driving Europeans to hunt. However, there were other reasons that hunting was crucial for European imperialists. One way for a military general to obtain more information about the territory he was going to occupy was to have his soldiers go out to hunt and get to know the terrain. ${ }^{170}$ Hunting, as William Beinart suggests, served dual purposes; it was a sport indulged in out of boredom and recreational interests, and also a practical device to control the Indian environment. European hunters were not the only ones involved in hunts. Indians were also involved in hunts.

One of the reasons men hunted was because of the popularity of the sport. Game was on the minds of all Anglo-Indians. Malcolm Darling, an Indian civil servant knew that most Anglo-Indians only cared for shikar and gossip and were uninterested in more engaging intellectual discussions. It was one of the reasons that he did not get along with most Anglo-Indians because he preferred more stimulating conversations. ${ }^{171}$ For example, upon entering an Anglo-Indian home, trophies were generally shown to another Anglo-Indian or British man. Mr. Moreswith, the resident engineer of Kazapet showed Col. Larking his various hunting trophies when he visited his home.

Hunting was also a tool of imperialism. European hunters waged war on India's

\footnotetext{
170 William Beinart and Lotte Hughes eds., Environment and Empire (Oxford: Oxford University Press, 2007), 88 .

${ }^{171}$ Clive Dewey, Anglo-Indian attitudes: the mind of the Indian Civil Service (London: Hambledon Press, 1993), 148.
} 
animals to symbolically defend the $R a j$. Defense of the $R a j$ was a constant necessity that transformed regular shooting expeditions into maintaining control over the natives. Game was directly referred to by their Indian "equivalents." For example, a hunter noted how a boar "stood a little over 36 inches, and was one of what you might call the fighting Jat." 172 The hunt was therefore a way to symbolically control the Jats, a martial race of Northern India. The imperial hunt was obsessed with putting wildbeasts and wild "castes" under the control of the shikar sabib. Dangerous elements of the Raj would be curtailed by imperialist hunters.

Hunting in colonial India was not merely a pastime, but an imperial activity. Where the British officers chose to shoot, the village was obliged to provide food and other necessities. A perwannah or order from a district magistrate demanded that villagers comply with these policies. If British sportsmen were not given supplies so that they could keep on hunting the wild animals, then there were other ways to obtain them. One sportsman noted how he "tied him [the village headman] to a post in the verandah, when, as if by magic, everything I wanted was forthcoming." ${ }^{173}$ Cruelty and intimidation towards local villagers occurred in the name of sport. Empire has long been associated as a realm of violence between the imperialists and the colonized. However, in many cases, the British did not even need to demand supplies or help from the local villagers. For

\footnotetext{
172 Fitz William Thomas Pollok, Lieutenant-Colonel. Sport in British Burmah, Assam, and the Cassyah and Jyntiah hills...(London: Chapman \& Hall, 1879), 80.

${ }^{173} \mathrm{Ibid}, 85$.
} 
example, once a British hunter shot some duck, "some Burmans, who were going up in a small boat, without being asked retrieved them for us." 174 Of course, European officials also helped ensure that the hunt could take place in a grand style. For example, an Assistant-Commissioner of Burmepetah, a district in Assam, constructed huts which were "built at different places"175 along the hunting route to ensure that his fellow European huntsmen could take pleasure in hunting. Development in the form of the construction of bungalows would benefit Europeans, rather than natives.

While perwannahs did give British sportsmen compliance from the Indians, they were also liable to being taken advantage of by Indians. In Kashmir sepoys were distributed to sportsmen for protection purposes. Even though the British had an imperial prerogative to facilitate sport, Indians did have some agency as actors and sought to take revenge on the sportsman possibly due to unequal relationship between the British and the Indians. Arthur Brinckman writes that "A sahib in Cashmere is looked on as a lawful object for plunder. Everyone tries to get as much out of him as he possibly can."176 Brinckman discusses how Indians in the village where his tent was set up in camp charge extra for basic staples such as flour when they know a British man is paying for it.

Similarly, he narrates his experience of being swindled by his servant named Malik who

\footnotetext{
${ }^{174}$ Ibid, 4.

175 Ibid, 21.

176 Arthur Brinckman, Rifle in Cashmere: a narrative of shooting expeditions in Ladak, Cashmere, Punjaub, etc., with advice on traveling, shooting and stalking: to which are added notes on army reform and Indian politics (London: Smith, Elder, Co., 1862), 177.
} 
showed him a page from the Llama Bible on which was written the cost of coolies and a yak (for transportation) amounting to Rs. 80 when it was only Rs. $60 .{ }^{177}$ Shepherds and farmers despise and do not trust the servants of the sahib who swindle them for foodstuffs as well. The power that servants and shikaris had over the villagers because they were working for a British man often led villagers to comply to the unreasonable demands from their servants. An honest servant was said to be difficult to acquire.

Hunting was also a time when Britons could go into remote villages and shoot ferocious game. Hunting was also a venue where the British and Indians could stare at each other. The villagers who lived closely to the duck shoot came out to view the smallgame hunt. Larking writes they "came out in force to stare as most of them never having seen a sahib before."178 After coming close up to a young boy, the boy ran away screaming for his life possibly because he had never seen a white man before. These chance encounters were a way for both sides to learn about the other, for Britons to establish an imperial presence and for villagers to take in the scene. Most villagers did not have the audacity to speak to the sahibs, but they enjoyed watching the scene, and the sahib must have enjoyed giving them a scene for which they were awestruck and impressed. The attention they received at shoots gave them all the more reason to continue hunts in the midst of curious villagers.

\section{Masculinity and Hunting}

177 Ibid 53.

178 Col. Cuthbert Larking, Bandobast and Khabar Reminiscences of India (London: Hurst and Blackett Ltd., 1888), 198. 
Sportsmen preferred game that were traditional such as bears and deer as well as dangerous game such as tigers. British sportsmen were aware that shikaris sometimes spent their time killing squirrels and selling their skins at Srinagar instead of spending time to kill more dangerous game. The meeker animals of Kashmir were not longed for, however sportsmen did shoot them anyway. Arthur Brinckman sums it up well when he writes that he could shoot forever in the hills of Kashmir but "I should be sorry to look back and think that I had spent a lifetime killing wild goats." ${ }^{179}$ Larger game which afforded a good stalk were always preferred over meek and humble goats. His description of burrel who he states are "a very stupid, uninteresting animal (....who) are very ease to stalk" suggests he wants much more of a challenge out of obtaining game as well as an equal playing field in which to showcase his manliness. ${ }^{180}$

When there was no kill, British men were extremely dejected and upset. Hunting had an obvious endpoint and goal - the death of an animal at the hands of the hunter. Colonel Larking writes that a "deep depression stole over in at the announcement 'Gharra nay' as that generally meant an idle day in camp and broiling in our tents." 181 "Gharra nay" meant that the animal did not die. The death of an animal marked the masculine prowess of the shooter and also the clamor in the forest where coolies would be sent to drag the body back to the village in order to have it skinned and the meat distributed along with a nice trophy to feel satisfied about.

\footnotetext{
179 Brinckman, Rifle in Cashmere, 111.

${ }^{180} \mathrm{Ibid}, 43$.

${ }^{181}$ Larking, Bandobast and Khabar, 137.
} 
Reminiscent of all the pageantry of the Raj, trophies were the ultimate prize of the regal hunt; trophies that sportsmen, both British and Indian could acquire.

Hunters chose which animals to shoot on the basis of whether or not they would serve as good trophies. Mrs. Gardner writes that "Alan wished to add their big horns [sambhur] to his trophies." 182 Trophies became symbols of masculine identity in India. Prized skins of the tiger or "Sher Khan" were adorned on the walls of the bungalows where British sportsmen resided. The tiger was the ultimate prize trophy mainly because of the animal's reputation as a ferocious beast. The record of the hunting expeditions was preserved through the transformation of select tiger remains, like skins and sometimes the head into a trophy - reminiscent of all the other ornaments gathered from the Raj. Furthermore, it was necessary to tabulate the lengths and widths of the animals that were killed.

The larger the animal, the greater the "sport," the greater the domination and exploitation of Indian game. Sportsmen's trophies also represented their victory against nature and their inherent manliness. These were one of the most prized items one could obtain from the Raj.

\section{Paternalism}

European hunters prior to the 1890 s generally defended, protected and informally worked for the Raj. While hunting was also undertaken in India by villagers who sought revenge on man-eating tigers, more often, European sportsmen joined the bereaved

\footnotetext{
182 Nora Beatrice Gardner, Rifle and spear with the Rajpoots...(London: Chatto \& Windus, 1895), 244.
} 
member or a British official would take on the cause of revenge upon the tiger out of sympathy or rather due to a paternalistic belief that they would be able to take care of the local villagers and also enjoy some "good sport." In many cases, Indians relied on British officials to take care of the predators. Some villagers even demanded restitution from a British official if animals had harmed them or their family members. For example, one widow demanded money from the Deputy Inspector-General of Police of Bengal, Edward Baker for a tigress that killed her husband. Baker notes that "this popular notion struck me as somewhat illogical ; for what had I done, and who was I, that I should pay a deodand for the tigress which had killed, eaten, and digested a man never seen by me, and whose name had never reached my ears? The widow clearly expected this much of me, and the dusky crowd accepted the claim as quite reasonable." ${ }^{\prime 83}$ Implicit in this exchange is the British claim to be the village protectors. Colonial officials therefore were directly responsible for controlling India's jungles. The expectations of British officials to protect local communities from wild animals was a major responsibility for the Raj.

George Orwell's essay "To Shoot an Elephant” similarly describes how a British Burmese police officer was called upon to shoot an elephant that wreaked havoc in the village since the villagers had no guns to protect themselves. While the police officer was scared, he could not show his un-manliness to the Burmese as he had to act like a sahib.

${ }^{183}$ Edward Baker, Sport in Bengal: and how, when and where to seek it (London: Ledger Smith \& Col, 1887), 141. 
Similarly, he could not show any compassion for the fallen animal because it was unimperialistic to express emotions for Indian animals in front of Indian subjects. The almost unreal, dramatic experience of hunting down the elephant was an everyday facet of British imperialism. Colonialism's benevolent side can be seen through the paternalistic hunting of these rogue animals as officials were called upon to take revenge upon the marauding, man-eating tiger. The British also acted as religious patrons to the Hindus as they took revenge upon the tigers who killed their cows. The act of hunting also captured the awe of the local villagers who looked up to "gallant" 184 British officials who summoned the villagers to come see the dead beast. It was also a display for colonial manliness designed to instill the message of authority and control. This act legitimized British rule while simultaneously also gathering an applause for their good sporting skills.

The imperial hunt also sought to emphasize the paternalistic nature of the $R a j$. The remnants of meat acquired from the shooting expedition would be distributed to the local villagers. For example, the villagers of Assam were happy to have the game to fortify and introduce variety into their diets. In some cases, the villagers would ask the sportsmen to kill a few deer for them because they did not have the guns to do so. The locals, especially in Assam ate rhinoceros meat, therefore, the British hunter believed it was necessary to distribute this meat to the local villagers, rather than just leave the

\footnotetext{
${ }^{184}$ Anonymous, “Tiger-Hunting in India," The Atheneum; or Spirit of the English Magazines (1817-1833): March 1, 1821, 8, 2: 413.
} 
carcass there since only the head was necessary for trophy keeping purposes. British officials also had to provide meat for their servants. Therefore, the meat acquired from the hunts went solely to the Muslim servants. Edward Baker notes that "our custom was to send to camp all the beef [buffalo and cow beef], and to reserve the tongues and prime joints for our own table." 185 Similarly, in Africa, according to Edward Steinhart, British officials believed it was necessary to provide meat to the servants of the safari and this only accelerated the hunting of additional animals apart from trophy keeping animals. Missionaries in Africa similarly distributed meat to the Africans, and the dependence on meat was part of European paternalism.

While sportsmen were detested among some farmers and shepherds in Kashmir mainly because of their servants, villagers also flocked to the sportsmen in Kashmir. Since the sportsman was the representative of the imperial government and the Raj, regardless of whether that man was actually a military officer or Indian civil servant, villagers hastily caught up with the sportsman wherever he was encamped to ask for western medicine (typically quinine) or alcohol such a rum or brandy. While sportsmen often attended to the medical needs of their own shikaris first, their expertise in diagnosing and advising villager-patients on what to do, even though they did not have any formal medical training, was a great asset to the villagers who resided next to game. Some sportsmen used an all-round ointment such as Holloway's ointment for swelling and dog bites and chapped skin.

185 Baker, Sport in Bengal, 184. 


\section{Reliance on shikaris, servants, and Indians}

Prior to the 1890s, Europeans were dependent on natives to carry out the imperial hunt. The Lieutenant Colonel of the Madras Staff Corps in 1879 noted how the "Ghoorka sepoys were encouraged to shoot whenever there was a chance, with most beneficial results, as it made them good shots, and taught them to go noiselessly through the jungles." 186 They were encouraged to shoot so that they could practice their military skills. The Gurkhas were also very helpful as a backup accompaniment force. For example, the Lieutenant noted, "the Ghoorkas dropped their rifles, and with their kookries or knives, without which no Ghoorka ever moves, they hacked the leopard almost to pieces on the man. As the beast fell off, Colonel Hicks, who had run up, put a ball through its head ; but it was not needed, as it was already dead."187 While the account of the hacking of the leopard seems over-exaggerated, we should be aware that the Gurkhas' manly skills were very much in favor. Of course, as Heather Streets states, Gurkhas were a special martial race that were given preferential treatment and allowed to hunt because of their masculine prowess and their strong warrior abilities. British military officers were not the only ones who engaged in hunting. Martial sepoys or infantry soldiers were called upon to fight the dangerous elements in the Raj: the beasts of the jungle.

\footnotetext{
${ }^{186} \mathrm{Ibid}, 37-38$.

${ }^{187}$ Ibid, 40.
} 
Even European adventure hunters were dependent on Indians to help them hunt prior to the 1890s. European hunting in the fringes was dependent on local villagers because they would often not be able to find game had it not been for the friendly nature of many tribals, villagers or shikaris. As one European sportsman puts it, "some Cossyahs...said they would show me game if I came to their village." 188 In places like Assam where dense tropical foliage was present and where native shikaris or hunters were not to be found, European hunters relied on local villagers who knew where the game resided. Game was generally found off the main cart roads and difficult to find areas, especially in the largely wooded areas. The native shikari was generally a tribal man from low-castes such as the Bhils or Gonds. Their ancestral occupation was that of hunting. They were different from elite natives like zamindars who engaged in hunting, since this was their primary means of subsistence. Shikaris were not only a guide to the maharajas and the British, but they were also considered essential because their skills and knowledge were deemed crucial to the success of the hunt. For example, an anonymous customs officer writing in 1874 noted how a shikari could "tell by the droppings of a deer whether it is feeding, alarmed or fled." 189 So, they possessed skilled knowledge based on careful observation of the environment, and this aided them in the tracking of game. Similarly, the shikari could associate a footprint with a particular

\footnotetext{
188 Ibid, 30.

${ }^{189}$ By a late customs officer, Past Days in India; or, sporting reminiscences of the valley of Soane and the basin of Singrowlee (London: Chapman \& Hall, 1874), 25.
} 
animal. This native knowledge was critical to successfully knowing when to shoot and in what direction since they were deemed to be expert trackers. Shikaris were also people who helped create astonishment in the eyes of the British. The tales of the shikari were always sought after especially by novice hunters. A hunter named J.C. Fife-Cookson related how the "shikarie accompanied me to give advice." 190 This advice was crucial, since hunting in colonial India as in colonial Africa, was a collaborative task. Wild game hunting could be a very dangerous undertaking, therefore it was imperative for Europeans to have native collaborators to hunt the wildlife.

The bond between shikaris and sahibs was quite strong despite differences in class. Sahibs were well aware of the intimate details about a shikari's life and many sahibs shared information about themselves. Arthur Brinckman, for example knew that a shikari's wife took another lover. One Ladaki shikari named Puljaur even left his grandmother's ashes for his sahib to bury for him. Arthur Brinckman writes of his shikari: "here I took a fond farewell of Puljaur and I really felt quite dull for some time after his departure." 191 The bond between shikaris and sahibs could be further analyzed by deconstructing the description sahibs gave of them. Arthur Brinckman writes of his Ladaki shikari named Puljaur: "He was a dapper little fellow, with a long pigtail, scarcely nor hair on his face, eyes that seemed to be laughing (....) immensely fond of chaffing, continually playing practical jokes, very fond of wing and flirting with every woman he met indoors or out. In fact, he was the most vivacious, jolly little fellow of

190 J.C. Fife-Cookson, Tiger-shooting in the Doon and Ulwar : with life in India (London: Chapman \& Hall, Ltd., 1887), 47.

${ }^{191}$ Brinckman, Rifle in Cashmere, 58. 
ever had to do with out here, and worth his weight in gold." 192 Brinckman's description of Puljaur makes it seem like he knew him his whole life. It is quite evident that he speaks highly of him and treasures his companionship with this esteemed shikari, which is made to be a great delight in his life.

The hunt was also dependent on large numbers of Indian servants and coolies. Many of these coolies were required for the skinning and cooking of the meat from the game that was shot. The aforementioned customs officer noted how the meat of a hare was prepared into a curry by the local help. Hunting provided Europeans with variety in their diet. While some tasks were deemed appropriate for the servants, many British officials believed that the servants could not be trusted because they lacked hygiene skills. For example, Charles Russell, a Senior Deputy Conservator of the Forests working in Mysore noted how servants could not be entrusted to "boil water for drinking purposes. ${ }^{193}$ Generally, hunting entailed long hours of lookout. Indian servants were deemed fit for to sit in a charpoy [charpoi] or bed made in the tree for lookout purposes. This was generally the work of the shikari. While hunting was certainly a dirty task, it was also a grand task even if it was not sponsored by a maharaja. Indian villagers were necessary for the tom-tom beating of the hunt. The beaters were employed to pull back the dense foliage of the Indian forests, while creating such a commotion that would scare the wild animals and bring them into a position that would be more suitable for

\footnotetext{
192 Brinckman, Rifle in Cashmere, 41-42.

${ }^{193}$ Charles Edward Mackintosh Russell, Bullet and shot in the Indian forest, plain and hill. With hints to beginners in Indian shooting (London: W. Thacker \& Co., 1900), 25.
} 
shooters to shoot them. Other servants were necessary for the purpose of constructing crucial netting fibers to trap the animals. Shikar, therefore, was a grand process that relegated large numbers of Indians to menial tasks all for the expressed purpose that the British and the maharajas could enjoy the fruits of the hunt.

Shikaris and coolies were not the only Indians that the British came to rely on as they also relied on Indian elites. A large sampling of British males received the opportunity to be guests of notable Indian males and were showered with lavish gifts and gracious hospitality, the only items that they had to bring along with themselves were their rifles and bedding. The collaboration led many British sportmen to speak highly of Indian elites. Colonel Cuthbert Larking dedicates his book entitled Bandobast and Khabar Reminiscences of India to the Nawab Ikbat-ud-dowlah Vikar-ul-umra of Hyderabad who arranged for a hunting trip to the forests of the Deccan for seven weeks with all bandobast or arrangements paid for and made in advance. Dr. Lauder, the Nawab's private secretary made the bandobast and promised cheetah black-buck hunting for the sahib. British interaction with the Indians also led to the formation of bonds between the two. For example after Mahomet Ismael Khan shot a chital buck, both Indians and British had venison at camp for dinner. ${ }^{194}$

Pig-sticking was a domain that encompassed both Indian and British elites. Tent clubs were organizations where pig-stickers would engage in pigsticking. Tent clubs also held contests and awarded prizes to the best pig-sticker. Tent clubs were not exclusively

${ }^{194}$ Larking, Bandobast and Khabar, 240. 
for British participants. Maharaja Rana of Dholpur had won several Tent Club cups for his excellent hog-hunting abilities as he speared the first pigs. Tent clubs, which appeared in non-cosmopolitan locations like Muttra were also known to present British individuals with much excitement and adventure and that is why its members hardly ever missed an opportunity to attend the pig-sticking events. For example, viewers described the pigsticking as an event where "our hearts [were] in our mouths" 195 waiting for the pig to die and for the pig-stickers to triumph. The adventure associated with the pigsticking event was highly masculine. The Tent Club was also an informal brotherhood where British residents got to know each other well. It was an exclusively male, elite sport. Hunting was a sport in the sense that it took a team effort to kill several pigs victoriously without being injured. Some Tent clubs had their own pig-sticking songs. Tent clubs were the predecessors to the Shikar Club, a hunting association for European hunters in tropical Africa that began in Britain in 1907 where imperialism and masculinity would be intermeshed.

Hunting in India was integral to class. The institutionalization of hunting as an elite sport was a construction of British tent club associations. However, the European practice of hunting for leisure trickled down to the natives who sought to emulate BritishIndian culture. Hunting was certainly a way to display one's privileged class. Edward

\footnotetext{
${ }^{195}$ Lieutenant M.F. McTaggart, "Pig Sticking Experiences in India," Wide World Magazine; an Illustrated monthly of true narrative, adventure, travel, customs and sport 8(January 1902): 357.
} 
Baker notes how a zamindar or landlord "styling himself as a Rajah"196 wished to show him game. This pseudo Raja organized over a hundred beaters who would be employed by him for the express purpose of helping trap game in the dense jungles near Manbhoom. The fact that the zamindar could muster up thousands of individuals for the hunt, not only displayed his wealth, but also emphasized his desire to be seen as a man of substance and influence. Hunting was a regal sport in India which sought to emphasize power, both in wealth and in prowess.

\section{Differentiation of Indians}

Although hunting involved the collaboration and even the camaraderie between the British and the Indians, it was also demarcated by difference. Race was perhaps the most important issue that divided Europeans and Indians in the hunting arena. There is also a shift in attitudes in the $19^{\text {th }}$ century. In the $18^{\text {th }}$ century, the British displayed a lack of restraint and excess in hunting in India, but somewhere along the way attitudes began to change and such actions were no longer appropriate to "gentleman" hunters. The "Orientalist" lack of restraint was seen as excess. Indians were also viewed as people who inflicted unnecessary cruelty upon the animals, whereas the Europeans were more kind by restricting their butchering to a few select animals. The tilt towards preferential treatment for European hunters was very marked during the 1880s. When local zamindars or landlords hunted, it was also categorized as poaching and very

196 Baker, Sport in Bengal, 242. 
unsportsmanlike. The sportsman Fitz William Pollok explains how the son of a zamindar in Bengal had

...cleared the country all round of rhinoceros and buffalos and tigers ; but he is a bit of a poacher for all that [... as he was] armed with a single-barreled cannon, carrying a 6-oz. Ball, he goes out on moonlight nights, when the rhinoceros are feeding, and do not suspect danger, and firing into one, he does not follow it up if it be only wounded, but leaves it to his shikarees to retrieve hereafter, which they generally do. In this way, in about six weeks he killed, I believe, thirty-four rhinoceros and ten tigers, besides other game, and has depopulated these jungles as far as game is concerned. ${ }^{197}$

This depopulation of the animals was not a concern in terms of the possible extinction of these animals and the loss of biodiversity affecting the ecosystem. Rather, the objection of white hunters was more that the grounds now became "quite spoilt for sport." ${ }^{198}$ Some shikaris were described as people who did not know how to shoot well and only disturbed the jungles for the Europeans. The lack of good gunmanship was another issue that the British used to justify themselves as the only legitimate shikar sahibs. Native shikaris and other hunters, according to the British, helped pave the way for the depopulation of the animals. There was hardly ever any assessment of the loss of biodiversity that was the byproduct of the European grand hunts. Europeans were content "with a few good shots."

The lack of knowledge amongst the Indian elite helped the British demarcate

\footnotetext{
${ }^{197}$ Fitz William Thomas Pollok, Sport in British Burmah, Assam and the Cassyah and Jynthia hills. (London: Chapman and Hall, 1879), 108.

${ }^{198}$ Ibid, 118.
} 
themselves from the maharajas and the general populace. The Europeans and the imperialists indulged in the classification of animals and trees like the peepul and jamon trees. The regal hunt also allowed for sportsmen to indulge in natural history. The imperial hunt was a way to explore the Indian environment. In many hunters' memoirs, European taxonomy and an interest in curiosities, drove the classification of flora and fauna. For example, when a serow was shot, Lieutenant-Colonel Pollok sent the head "to the curator of the Calcutta museum [for] WE did not know of their existence till then." 199 The need for the preservation of special species was a direct result of the exploration of the Indian fringes. The gathering of specimens was something that occurred during the regal hunt. It was an activity only fit for the elites, since other individuals did not appreciate exotic species. Local Indians, for example, believed that a bagh could be a tiger, panther, or hyena. Hunting, while dependent on natives and emphasizing collaboration, also demarcated and differentiated Europeans from Indians. This led to effective "othering" of elite and non-elite hunters. The nature of imperialism was always contradictory. Therefore, hunting as an imperial task was similarly very contradictory. While the maharajas provided for the accoutrements that allowed for the regal hunt to take place, their apparent lack of physical prowess as well as their lower station to the British sahib, allowed them to partake in the hunt but only on a less lavish scale. While the sahib sought to stick one large pig, the Nawab went for the "smaller of the

${ }^{199}$ Ibid, 29. 
two." 200 The Nawabs were also perceived as individuals who did not quite understand the regal hunt. A sportsman notes how a sow was spotted and the Nawabs "who thought it was a boar, amused themselves by chasing it all over the country." ${ }^{201}$ Unfamiliarity with the animals of the wild, meant a lack of familiarity with natural history and European curiosity and taxonomy. This ultimately meant that the demarcating of racial differences served to relegate the maharajas and other Indian elites to a lower station than that of the British sportsmen - regardless of their class. The British as the imperialists were the king of mini-kings. This interpretation challenges David Cannadine's argument that class trumped race at least among the level of elites.

The stigmatizing of natives coincided with the decline of game that was quite noticeable among Europeans in the 1890s. One Anglo-Indian or British resident in the late $19^{\text {th }}$ century India noted how "a class of men go wandering about with poisoned arrows, killing numbers of tigers and leopards, and picking up the horns of rhinoceros, who have died of their wounds, and which the sportsman has not had time to follow up." ${ }^{202}$ According to European hunters, they did not follow the etiquette required of the regal hunt and their hunting skills were more like those of a scavenger. The Indians who hunted with poisoned arrows are similar to the Kamba hunters of Kenya who were also denigrated by British officials mainly because hunting with poison did not demonstrate

\footnotetext{
200 Edward Baker, Sport in Bengal, 28.

201 Ibid, 29.

202 Pollok, Sport in British Burmah, 79.
} 
the masculine prowess of the individual against the beast.

Even though Indian shikaris were necessary for hunting, they were constantly denigrated for their lack of hunting etiquette, reason and masculine prowess. Shikaris of Afghan or Pathan backgrounds were prized because they were seen to be handy and hardworking. Martial races were always preferred because they were regarded as strong and effective hunters and kept quiet during the hunting process. Indian servants similarly did not have the ability to operate in cold climates thousands of feet above sea level in the mountain peaks. Their bodies were not acclimated to the conditions and as a consequence they generally became sick. Some feigned illnesses in order to go back home to their village, even going so far as to break dishes so they would not have to cook anymore. Most shikaris did not always follow hunting etiquette of keeping quiet while stalking game. Shikaris sometimes talked to sahibs while waiting for game, prayed for the kill, adjusted their pugaris (headpieces) or beat off fleas from the forests. This was a major problem for many British sportsmen who preferred silence so that the kill could be quickly achieved.

The large number of British sportsmen who came to Kashmir in the summer led to an increased demand for shikaris, many of whom did not have forefathers in the business. This often led to shikaris who did not know that much about game, which could explain some of the denigration that shikaris as a whole in Kashmir faced.

The major issue that divided sahibs from shikaris was the claim that the latter lacked reason. The lack of reason in shikaris led to a proliferation of superstitious stories about unreal imaginings and events concerning the spirits of wild game. Since Hindus 
believe in re-incarnation, most shikaris believed that the animals could come back to life. A shikari once told Arthur Brinckman that after shooting and skinning a bear it came back to life. Shikaris had charms they believed protected them from things like snake bites. These stories were viewed as lies and were completely rejected by Europeans because to a western mind that used reason no such event could occur. The lack of reason possessed by a shikari was typically explained as the average figment of the oriental mind. Superstitions were said to be rampant among almost all shikaris. Arthur Brinckman was aware of the phenomenon as most British sportsmen were and writes it was "my usual custom of never believing anything a native says." ${ }^{203}$ This was a contradiction especially since the British relied on native knowledge and their whereabouts of the terrain. He made his decisions in the hunting arena accordingly as this was his motto. It did nothing to deter the sportsman from going into the jungles to seek game. The overzealous child-like propensity of most shikaris was also detested by most sportsman who enjoyed giving a display of awe to such shikaris and were happy to have such individuals sit with their mouths open in the midst of shikar, however at the pivotal moment when killing game silence was demanded, and more often than not, silence could not be maintained by these "child-like" shikaris. This was also attributed to a lack of reason. As such several shikaris had to be restrained. Arthur Brinckman discusses how he had to seize "my shikaree by the nape of the neck, and [force] him down, when getting excited." 204

\footnotetext{
${ }^{203}$ Brinckman, Rifle in Cashmere, 115.

${ }^{204}$ Ibid, 77.
} 
By the 1890 s, Indian non-elite hunters were no longer required. According to certain British officials, villagers did not have the skills necessary to undertake the killing of the tigers because they did not use the right techniques associated with the hunting etiquette and because they were not masculine enough. This was a construction to legitimize British control over hunting.

British sportsmen tended to criticize Indian sportsmen who were not shikaris and were not educated hunters. Men who hunted for a pass time were often perceived as murderers, perhaps because the British wanted to deflect criticism against their own hunting. Khagan chiefs hunted down an ibex with sepoys doing the shooting for them. Their excess was emphasized as the sepoys shot around 50 shots for a single ibex and then his head was hit by a hatchet by one of the men. Most likely one or two shots would have killed the ibex, however, the numerous shots writes Arthur Brinckman made him feel that he had " witnessed a murder." 205 Perhaps the sepoys over exercised the firearms and ammunition they had or perhaps they were excited and shot several rounds or were afraid the animal might attack them. This represented a lack of hunting etiquette and an absence of restraint in order to minimize pain on the animal, which most likely suffered a long, gruesome and painful death.

\section{Hunting as a Regal Sport}

The shift to the regal nature of imperial hunting occurred prior to the 1890 s, but was solidified by the 1890s. The imperial regal hunt differs from the regal hunt of the

\footnotetext{
205 Brinckman, Rifle in Cashmere, 13.
} 
Mughals because it includes the British. As British power becomes more secure, the British end up playing an important diplomatic and ceremonial role as they are senior guests accompanied by maharajas. Hunting was perceived as a princely sport. Various Anglo-Indian clubs were solely devoted to hunting in a princely style. The Calcutta Tent Club was exclusively a hog-hunting club. Its members hunted pigs around the area from Calcutta to Diamond Harbour. The members were all residents of Calcutta. The President of the Club would "record the sport of the day, taking count of the first spears from the members and their friends from left to right, while cheroots and hookahs were lighted." ${ }^{206}$ The Tent Club had the best camp equipment, cuisine and wines according to Edward Baker, a former member. The leisurely upper-class activities of drinking wine and smoking hookahs along with unrestricted hog-hunting made this less a sport than an elite social club.

Certain rules of hunting etiquette were standardized as the development of etiquette was part and parcel of the regal nature of hunting. For instance, a sportsman could occupy a nala or hunting grounds for as long as he wished, and another sportsman could not come into this territory until he was done with it. The hunting outfit was a khaki colored suit. Furthermore, European sportsmen had to actually shoot the animal and collect it directly afterwards to make sure it was the same animal. Finding animals which were not shot, but were "found dead the next day [...was a ] system of sport [that]

\footnotetext{
${ }^{206}$ Edward Baker, Sport in Bengal, 45.
} 
is horrible poaching, and utterly unfit for Europeans." ${ }^{207}$ As a manly European, one by etiquette collected the animal that one had personally shot. The natives of Burma and other territories often left animals wounded or dead and did not bother to collect them. This was termed as poaching by European sportsmen. The unsportsmen-like nature of the natives who did not follow the rules and regulations of hunting etiquette were severely stigmatized.

The regal hunt allowed European sportsmen and women to enjoy the grandness of Indian nature. The regal hunt was something that differentiated the Europeans from the Indians. The Europeans believed that the natives who lived lives of toil did not have the leisure time to appreciate the beauties present in nature. Many European sportsmen emphasized the grandeur of nature's delights. As a European sportsman noted, "the view from the top [of a hill] was very lovely." ${ }^{208}$ The open country was exceedingly beautiful. Lieutenant Colonel Pollok goes on to state that the road to Jowai is exceedingly pretty, passing through undulating country[...] we had to cross several lovely streams and marshy woods." ${ }^{209}$ Beautiful scenery could be enjoyed during the hunting expeditions. Describing the beauty of the terrain was essential for publishing these memoirs as well as relating the grandness of India's environment. Many British sportsmen emphasized the

\footnotetext{
${ }^{207} \mathrm{Ibid}, 46$.

208 Pollok, Sport in British Burmah, 42.

${ }^{209} \mathrm{Ibid}, 44$.
} 
striking nature of the jungles which were teeming with game of all sorts. The immense and extraordinary amounts of game delighted British sportsmen, especially since Britain's forest animals and woods were in decline due to industrialization and urbanization. Several hunters also sketched these sceneries as an addendum to their work.

Sportsmen emphasized the importance of knowing and understanding Hindi, the most widely spoken language in North India in order to have the best relationship with one's shikari. Knowing Hindi made sportsmen cultured individuals. Most Anglo-Indians, especially those who were in the military or were in the Indian Civil Service had a fairly good command over basic conversational Hindi and knew the words for the different types of game in Hindi. Some sportsman such as Arthur Brinckman went so far as to publish helpful words and phrases of Kashmiri and Ladaki to help other sahibs who went to visit those locations for the purposes of big game shooting. Comprehension in Hindi allowed the sportsman the ability to understand the type of animals that were in the vicinity, as well as other pertinent information which could be life saving. In other cases, the sportsman often overheard people discussing wild animals and the sportsmen then got a chance to bag that animal.

After the 1890 s, there was a considerable shift towards regalness in the hunt. The maharajas were, however, a very crucial element in helping construct the regal hunt. An unnamed raja of Bengal wrote Fitz-William Pollock, a sportsman in 1879, to request Pollock 
...to accompany him to his barge to partake of the shikar previously prepared for our amusement. We rowed some miles towards a rising ground on which we landed, and were then carried on men's shoulders to a temporary stage erected for the occasion. On surveying the arena, round us I found that the inclosure was not less than thirty acres, surrounded by a stockade and lined on the outside by the vassals of the Rajah. They had previously driven the wild beasts of the country to this place[...]The sight was whimsically wild and magnificent, the concourse of people immense, the whole population of the hills and the plains having turned out for the occasion [...]200 of the largest wild buffaloes inclosed, some hundreds of the large elk-deer...These animals were now galloping around us in quick succession, when the Rajah, turning politely towards me, asked me to begin the shikar by taking the first shot [...]I therefore raised my wellloaded rifle to my shoulder, and taking a good aim, to my astonishment, dropped a large buck dead on the spot. There was immediately a general shout of admiration. I on my part put my pipe into my mouth, throwing out volumes of smoke to show my indifference, as if the event were a matter of course. ${ }^{210}$

The raja would get the second shot and kill a deer on the spot and receive a big round of applause from the hills people. The Lieutenant Colonel however was still unhappy with the lack of hunting etiquette practiced by the Jynteah raja. The Lietenant Colonel notes how "my savage friends were little accustomed to stage effects or luxuries of any kind. The noble animal [referring to the elephant used in the staged hunt] had not even a pad on his back, a rope round his body was his only harness." 211 Only people unacquainted with the luxuries of an elephant saddle would entertain European guests without key accoutrements necessary for a regal show. Thus, even though shikar as a regal sport was practiced by the maharajas, the issue of race relegated Indian elite hunters

\footnotetext{
${ }^{210} \mathrm{Ibid}, 34-35$.

${ }^{211} \mathrm{Ibid}, 35$.
} 
to a lower position under the British.

The Jynteah raja created this staged hunt to impress upon the people his power and wealth. The increased pageantry of the Raj that David Cannadine remarks occurred during the 1890 s was not solely a British construction. Indian rulers were very much interested in displaying their grandeur and hunting was one of the domains where recreation intermeshed with power. However, the raja also sought to show that he was on par with the British, even a simple Lieutenant Colonel of the Madras Staff Corps. Therefore, the raja used hunting as a domain to placate himself as an imperialist, just like the Lieutenant Colonel. The imperial hunt was therefore an amalgam of Indian and British styles of hunting. The British, in this case the Lieutenant Colonel used a gun to shoot the animal, which was the typical British style of shooting. The Indian raja used an enclosure after driving animals to a particular location. This is reminiscent of Mughal style hunting and typically viewed as staged hunting, which was seen as "Orientalist" excess. The crowds who were gathered to watch helped establish the event as a regal undertaking.

\section{Nascent Ecological Awareness}

As the dominant hunters of the jungles, the British also had to become the protectors of the jungles. The preferential treatment of European hunters during the 1890s coincided with the need to conserve the dwindling stocks of wild animals. 
By the 1890 s, the shift to preferential treatment for European hunters also coincided with the rapid decimation of game and the shift of the game frontier to remote areas like the Sunderbans, where today's wildlife reserves are located. As Edward Baker notes in the late 1880s, rhinoceros "have disappeared from Purneah [Purnia] and the neighbourhood of Rajmahal and Sikrigully, where they were plentiful fifty years ago."212 Similarly, Baker states that marsh-deer or barasingha only survive in Maldah, Dinagepoor, and near the Soonderbuns [Sunderbans], and in Julpigoree. ${ }^{213}$ The extent of the decimation of game was therefore widely apparent in many sportsmen's memoirs and obvious from their subtitles, as they directed European sportsmen on where to find the remaining game.

\section{Concluding Remarks}

The structures of imperialism along with its contradictions can be analyzed by deconstructing the imperial hunt in British India. While the British as the imperialists sought to control Indian wildlife present in the forests and in other domains for paternalistic and personal reasons, they were nevertheless dependent on the native shikaris, the villagers, and the maharajas to continue their sport. Hunting became institutionalized into a regal sport by the 1890 s where the British became the dominant shikar sahibs, followed by the maharajas and other Indian hunters who were likened to

\footnotetext{
${ }^{212}$ Edward Baker. Sport in Bengal, 36.

${ }^{213}$ Ibid, 37.
} 
poachers. The hunt became more formal with the publication of shikar books, which rose exponentially and standardized the hunting practices of the British in India. It relayed to other griffins or new entries as well as other hunting enthusiasts into India the policies and procedures of hunting as a sahib. Elite Indians were also denigrated for their excess in the $19^{\text {th }}$ century, in addition to non-elite hunters for their "poaching." An emphasis was also placed on the sportsman as a masculine imperialist who engaged in recreation fit for a ruler of India. British recreation revolved around shikar as sport. Hunting became transformed from a native subsistence activity, to a grand act divorced from reality that was largely based on the Mughal traditions of dominance over the environment. The imperial hunter was similar to the Mughal regal hunter as he heavily relied on shikaris and Indian orderlies, and they both reveled in the countryside. The imperial hunter was different in that he had a sense of etiquette. The imperial hunter's relations with Indian shikaris displayed an unequal relationship and imperial hunters emphasized their difference in an effort to mark their elite status as sahibs. The shift towards hunting as an elite sport in the 1890 s was mainly a byproduct of the British Sahibs who emphasized a regal tradition of hunting and denigrated shikaris, poachers and maharajahs for their 'Orientalist' excess. The development of etiquette, masculinity, and nascent ecological awareness were part of the components of the regal hunt. 


\section{Chapter 4: Hunting and British hunters in colonial India, 1900-1947: New Technology, Humanitarian Hunters, and Growing Conservationist Awareness.}

While certain characteristics of hunting in colonial India remained constant from the $19^{\text {th }}$ to the $20^{\text {th }}$ century, such as the British involvement in hunting and its status as an “imperial sport," other aspects underwent substantial changes. This chapter argues that a new hunting practice appeared in India during the late 19th century, which was an amalgamation of Indian and English hunting styles. It was also tailored to the environment and had its own laws and meanings. Certain localities were hotbeds for hunting. The character of British hunting can be summarized as gentlemanly masculine, as well as imperialist. Distinct differentiation between hunting by tribal peoples, which the British classed as "poachers," and by British sportsmen, which they classed as legitimate were also clearly defined in the $20^{\text {th }}$ century. By the $20^{\text {th }}$ century, a number of new developments appear, including humanitarian hunters who only hunt to protect villagers, the introduction of new technology, a greater sense of nostalgia for the past, a greater introduction of emotion and artificial rearing, and the emulation of maharajas by sahibs. These changes along with a strong sense on restraint and a conservationist awareness were important features that differentiated most (though not all) $20^{\text {th }}$ century hunters from their $19^{\text {th }}$ century counterparts. 


\section{Constants}

The excitement of the hunt remained a constant in both the $19^{\text {th }}$ and $20^{\text {th }}$ centuries. James Best writes of the adrenaline rush that he experienced when out hunting in Kashmir when he states "my heart [was] in my mouth and all my attention [was] fixed ... Four of them looked huge heads to me; my wrists froze, my heart pumped and I was overwhelmed by all the symptoms of buck fever. Khuzra held back my rifle until I steadied."214 Big trophies often led to an explosion of excitement among British sportsman. The shikari or Indian hunter played an important role in breaking the British sportsman away from the trance that often accompanied the excitement and sense of adventure that they experienced when out in the jungles. Despite such continuity, there were some distinct changes in the $20^{\text {th }}$ century. Indians shikaris were no less excited with the prospect of game. The author of Sport on the Nilgiris writes of the excitement that most Indians felt when they found or located a tiger. Shikaris literally ran back to their sahibs to tell them about it. His shikari said "aiyah, aiyah pillee pille" roughly translating to "Sir, sir a tiger a tiger." 15

By the $20^{\text {th }}$ century, more British sportsmen's books introduced emotion, however they were the minority. The feelings of British sportsmen were expressed in full force in their accounts. James Best writes that "I have never shot anything sitting up over a kill or a live bait ... If it be a live bait I can never rid myself of my painful sympathy with the

\footnotetext{
214 James W. Best, Forest Life in India (London: J. Murray, 1935), 31.

${ }^{215}$ F. W. F. Fletcher, Sport on the Nilgiris and in Wynaad (London: MacMillan, 1911), 194.
} 
feelings of the bait and that spoils the whole performance." ${ }^{216}$ Feelings of guilt are present in this statement. Still, most sportsmen would not have shared this attitude.Best was one of those few men who had reservations about killing an innocent domestic animal simply for the purposes of obtaining sport from a tiger.

For a very small minority, hunting drew Europeans closer to animals in a bond that could have never occurred in England. This could be particularly attributed to the fact that Anglo-Indians typically lived without their children who were raised in Britain. Nicholls, a tea planter from Assam, mentioned how his friend Mr. Farrar of the Sangsua tea estate had a pet ape that would eat biscuits from a plate! ${ }^{217}$ The boundaries between wildlife and domesticated animals were broken down in this unique case as the ape was treated like a part of Mr. Farrar's family and was taught to behave like a domesticated pet.

Hunting in British India retained a few distinctive English elements such as the use of hounds in hunting. Even though hounds were used in hunting, beaters, which were part of the Indian hunting tradition were also utilized. Therefore, hunting combined elements of both styles in order to adapt to the Indian environment. The Anglo-Indian hunt was quite popular especially with British sportsmen who had access to hunting dogs or kept pet sporting dogs. Published handbooks reveal that hunting sometimes occurred

\footnotetext{
216 Best, Forest Life in India, 128.

${ }^{217}$ Frank Nicholls, Assam shikari; a tea planter's story of hunting and high adventure in the jungles of North East India (Auckland: Tonson, 1970), 84.
} 
with dogs in place of beaters. For example, in the Nilgiri Hills, sporting dogs such as spaniels were used to help track birds and other small game. ${ }^{218}$ Hunting with hounds occurred in the $19^{\text {th }}$ and $20^{\text {th }}$ century, however it was not quite as popular as hunting with a shikari and typically occurred in remote areas where a more informal style of hunting flourished. Another concrete example of the amalgamation of traditions can be seen in the typical hunting camp. A hunter named Kildeer writes that "a capital soup can be made without meat $[. .$.$] have some good dhal, Bengal or bhoot gram, hindi chenna hulled and$ cleaned before starting. Take a cupful of this pulse, wash well and put into a stewpan with six or seven cups of water, two or three onions sliced, a saltspoon of sugar and small piece of lean bacon or bacon bone if you like to boil reduce the fire and allow to simmer." ${ }^{219}$ If one analyzes this recipe one would automatically assume that this is the recipe for yellow lentils, a staple main dish for Indians. However, the recipe is modified from the Indian dal to include bacon, a distinctively British addition to satisfy the palate of the Anglo-Indian.

\section{Reliance on shikaris \& the creation of the gentlemanly sportsman}

As Joseph Sramek has stated, although they claimed to be masculine men, the British relied heavily on Indians. As a result, masculinity could not be tailored to the commonly assumed idea that independence was part and parcel of the prowess. Instead it

\footnotetext{
218 Edward Backhouse Eastwick, Murray's Handbook for Travellers in India, Burma and Ceylon, $15^{\text {th }}$ edition (Calcutta: Thacker, Spink \& Co., 1938), 634.

219 Kildeer, Timely hints to amateur shikaries (Madras: Higginbotham \& Co., 1909), 85.
} 
was coupled with the imperialist idea to have control over other people's labor. In fact, the idea of servants is first imperialist, then bourgeois, then middle-class, but in India even ordinary Britons had Indians serving them because labor was cheap and because the nation had a tradition of caste servility where certain castes performed particular duties like sweeping.

The reliance on natives can be seen on the hunting grounds. Occasionally, the British engaged in hunting large game while riding on elephants. However, while elephants were quite safe and created a protective barrier for the British against wildlife, they could also pose problems to the men they carried. It was at this time that quick, intelligent action from the natives was required. Alexander Ernest Wardrop relied on his mahout, or elephant driver to help get an elephant out of quicksand near the Sarda River in Nepal. The mahout stated, "Sahib, there is a bend of the stream close above ; cut a channel and let the water into the fussund." 220 This suggestion saved the elephant's life as it loosened the quicksand that was binding the elephant into the ground. As this example suggests, the ingenuity of native mahouts were necessary for all activities associated with hunting.

The reliance on Indian shikaris or hunters such as Gonds and Bhils (the predominant low-castes from among whom the British recruited shikaris), almost never bothered Anglo-Indian resident men. Indians were also needed for basic camp

220 A.E. Wardrop, Modern Pig Sticking (London: Macmillan, 1914), 15. 
maintenance. In order to keep warm in the jungle or forests, a fire was necessary. James Best writes of Gond tribals who make a fire out of split dry bamboo and tree-cotton. The fire originated from rubbing the dry bamboo and the tree cotton together in a vigorous manner. Generally, British males carried matches to make a fire but in their absence they relied on their tribal shikaris. James Best says that this is a seemingly easy task to any Gond shikari and it is done in a swift manner.

The relationship between the British and Indian hunting partners was full of tensions and condescension. The reliance on shikaris often meant that British resident hunters' roles in hunting were limited to simply hiking and pulling the trigger. AngloIndian men often got very upset when they had to do more than their fair share of work showcasing the imperial nature of their role as premier sportsmen. Lieutenant-Colonel Charles Hugh Stockley noted that "there are plenty of frauds among shikaris, however, none are worse than the man who knows little about tracking and will never admit he is wrong ... the greatest fraud of all, as a class, is the Kashmiri. He is often a poor climber and indifferent stalker ... and consequently a lover of villages, with no desire to penetrate the remoter stalks of game." 221 Indian shikaris were a dying breed in areas where plenty of game could be located because many local villagers took up hunting as well and were not as skilled as shikaris whose ancestors had been shikaris. AngloIndians were accustomed to having their hunting plans drawn out for them and the actual

\footnotetext{
${ }^{221}$ Lieut.-Col. Charles Hugh Stockley, Shikar: Being tales by a sportsman in India (Bombay: Oxford University Press, 1928), 191-192.
} 
work behind hunting frustrated them as they demanded quick hunts so that they could revel in the trophy at the expense of the expert-tracker Indian shikari. Similar to Lieutenant-Colonel Stockley, Wardrop had a very poor opinion of shikaris. Wardrop states "the shikaries and their myriad [illegible] are usually members of criminal tribes, Bhils or Ramses."222 Nevertheless, the British had to put up with these "criminal tribes" because of their ability to track game. On the whole, many British sahibs enjoyed the companionship of their shikaris much like in the $19^{\text {th }}$ century. The love and hate relationship between shikaris and their sahibs often represented two opposing spectrums at different stages and times.

Some places were popular for hunting and shikaris there were in great demand. Kashmir, for example, was a favorite destination because of its cool weather. Best writes to the trainee hunter that prior to travel to a shikar destination it is best "to try and get the names of one or two good shikaris before one's arrival and to book them." ${ }^{.23}$ If shikaris could not be booked by the sahibs then the sahib was out of luck and could not go out shooting. A few sahibs decided to hunt by themselves though. Therefore, it was imperative to find and reserve a good shikari before another man booked him because one shikari could not be shared between two sahibs, especially if they did not know each other. These were tips that were crucial to novice sportsmen.

\footnotetext{
222 Wardrop, Modern Pig Sticking, 285.

${ }^{223}$ James W. Best, Forest Life in India (London: J. Murray, 1935), 134.
} 
Sportsmen also recommended shikaris to other fellow sportsmen. In Chamba, for example, the author of the Sportsman's Book for India recommended Dhassa, Mullah, and Bhagia. To locate these shikaris one had to simply write a letter "c/o Postmaster, Tissa, Chamba to get in touch with any of these men for the purposes of employment. ${ }^{224}$ Recommendations from British sportsmen allowed a shikari to receive a steady income. Positive recommendations also meant that a sahib would write a good chit or employment record card for that shikari.

Shikaris and hunters worked together in the $20^{\text {th }}$ century, just as much as in the $19^{\text {th }}$ century. For examples, James Best who worked for the Indian Forest Service stated how his shikari told him he "would watch if I slept." 225 He was referring to watching out for game at night up in a machan or platform in the jungles. This often led to overnight stays in the jungles. By rotating night watchman positions the shikari and the British sahib worked together as a team to ensure that each one would get their share of rest while making sure that the other person was not in harm's way. However, Indian shikaris often had a reputation to uphold and therefore sought to bag the biggest game and therefore shared the same objective as the Anglo-Indian hunter whom they guided on the hunt. They were frequently treated like equals as most received pay or meat for their services by some British sportsmen despite the fact that some of them were possibly from criminal backgrounds and were of low-status and caste. Anglo-Indian hunters advised

\footnotetext{
${ }^{224}$ Frederick George Aflalo, The sportsman's book for India. (London: H. Marshall and Son, 1904), 89.

${ }^{225}$ Best, Forest Life in India, 56.
} 
others to take care of their coolies and shikaris mainly because the shikaris' survival and health meant a bigger bag for the sahib or British sportsman. For example, an AngloIndian hunter who used the pen name of Ajax advised Anglo-Indians to "see that your servant's tent is comfortable and rainproof." 226 This sort of camaraderie was often seen in the British-Indian partnership in the jungles.

British sportsmen emphasized the need for religious tolerance during the hunt. In Burma, shikaris performed a pooja or devotional worship in order to kill lots of game without harm done to themselves. The pooja required coconut, plantains, spirits, pickled tea leaves, tobacco, egg, a spoon of cooked rice, tobacco and betel nut leaves. Sydney Christopher does not describe what the shikaris did with them but we can assume that they were offered to a deity in return for a wish. They may have been offered in a circular motion to the deity. Christopher writes that "this ceremony pleases them immensely and there are no reasons why the sportsman should deny them this pleasure as it costs him very little or nothing. ${ }^{227}$ Most British hunters respected Hindus, did not interfere with their customs or impose Christian or other Western ways on them. This further supports the contention that sahibs respected their shikaris and believed they were on an equal plain with themselves.

Indians who died fighting against game were seen to be brave men or women. James Best writes of a beater who was mauled by a tigress and died shortly afterwards.

\footnotetext{
226 Ajax, 'Good Hunting'!; or, What to do on shikar and how to do it. (Calcutta: Thacker, Spink \& Co., 1913), 25.

227 Sydney Albert Christopher, Big game shooting in Lower Burma. (Rangoon: Burma Pictorial Press, 1916), 69.
} 
His opinion of him greatly changed after watching him fight for his life for a few hours before his death. James Best states that the beater was "a fine fellow who made one think even higher of the native than ever." ${ }^{\prime 28}$ Showing one's manly strength was prized. In fact, when British men faced death after they were attacked, they bravely fought their way without complaining or crying or otherwise showing signs of great pain. The fortitude and strength within a man to maintain one's composure while dying was greatly prized and made one into more of a man than he was once before. The beater who died exemplified this behavior and this was viewed very favorably by British sportsmen. Manliness was one of the main characteristics that could put the sahib and the shikari on equal footing, however, in most cases the perceived lack of masculinity helped differentiate the shikari from the sahib.

Even though there was an aura of equality between the sahib and the shikari, the law always ruled against the shikari. There could be dangers to a shikari when hunting apart from being attacked by wild game. For instance, if a shikari directed the European to a nullah where shooting is forbidden, the shikari would be responsible for this mistake rather than the European. Ajax, a British sportsman, shot an animal in a location that was later found out to be forbidden. Instead of Ajax's sportsmen's license being revoked, the shikari was fined four months of wages and his license to accompany sportsmen cancelled permanently. ${ }^{229}$ The shikari would no longer have a way to provide for his family as his career would officially come to an end. The repercussions on the

228 James W. Best, Forest Life in India, 253.

${ }^{229}$ Ajax, 'Good Hunting’!, 53. 
Anglo-Indian hunter was comparatively miniscule. The Indian shikari on the other hand had his reputation forever tarnished and his ancestral occupation stripped away. Although it mostly seemed that hunting was a sport where Indians were on equal terrain with British residents, as the above example demonstrates, this was not always the case. In the end, Indians remained subordinated and were therefore ultimately responsible for all the possible pitfalls and dangers associated with the well-being of the Anglo-Indians.

Certain shikaris had a vested interest in killing game just as much as the drive that British sportsmen possessed. James Best writes that "Three times in my life I have seen a shikari on the verge of tears when luck went really wrong; they were as keen as I was." 230 Actual tears flowing down one's face translated to a lack of manliness and this was never seen, but the feeling of despair and regret led these men to become teary eyed and filled with emotions of despair. However, they held back their tears and repressed their feelings while showcasing their utmost desires of killing game in order to receive satisfaction and a feeling of accomplishment. Indians and the British worked in collaboration in the jungles.

While many British hunters were dependent on shikaris to find game, some experienced Anglo-Indian hunters who had been hunting for years were knowledgeable about where to locate game. The hunter Ajax, for instance, noted that "in districts where the buffalo herdsmen having extracted the cream from their milk, throw

\footnotetext{
${ }^{230}$ Best, Forest Life in India, 24.
} 
the buttermilk into a regular place every morning, and bears being very fond of this can be fairly easily shot over a pool [where the cream was dumped] at dusk." ${ }^{.231}$ Milk production was a common activity that attracted wild game and it often led to bears terrorizing villages. Most British sportsmen did not know this however. The wild bear was also fond of toddy trees. Wild animals continued to be a disturbance for many Indians and the British in the $20^{\text {th }}$ century. E.D. Miller discusses finding a boar in the sugar cane fields because it was attracted to sweetness and he was able to arrange for 200 coolies for that single boar. Many preferred to defer to Indian shikaris to let them know where these locations were as there are several accounts where Anglo-Indians applauded their expertise in tracking and their accumulation of local knowledge.

The government was another institution that helped Anglo-Indians in their hunting experience as it offered $d a k$ bungalows or rest houses for British travelers in such locales as the hill stations of Simla or Kashmir next to the Himalayan foothills in Northern India. The government also provided assistance to those who wished to hunt in the form of survey maps, which were not only fairly accurate as mentioned by several hunters, but were also available from each district. These survey maps were first conducted in Bengal for the purposes of tax assessments. Many experienced AngloIndian hunters wrote memoirs and published books directing others to seek advice from such persons as the Secretary of the Game Preservation Department in Srinagar

231 Ajax, 'Good Hunting'!, 13. 
or Indian maharajas such as Raja Bhuri Singh. ${ }^{232}$ The aforementioned individuals were said to be not only quite hospitable to hunters, but also men who helped provide information about the locations of game and the best methods of attaining the wildlife. Word of mouth however was simply the best way to become a perfect hunter. Mrs. W. W. Baillie mentions how her friend advised her to use a 12-bore rifle to shoot bison instead of an Express rifle as it was the best way to kill the animal. ${ }^{233}$

Indian orderlies had an incentive to find game for the sahib. Finding game could also supplement a coolie's salary as most reputable sportsman paid for knowledge about the whereabouts of game especially if they were unable to find it themselves. Hunting etiquette made the payment of khabbar or news customary. Frank Nicholls, who worked as an Assam planter, admits to offering a personal reward of Rs. 2 for news of any big game and Rs. 10 if it was shot by him and Rs.20. for a tiger or leopard. ${ }^{234}$ Coolies when not at work were presumably out looking for game or seeking information from local people about game animals. This made the sportsman's job quite easy as he did not have to be on the lookout and news came to him.

The $20^{\text {th }}$ century was also a time when "artificiality" was implemented on a widescale in the hunting arena to deal with the dwindling stocks of game. Artificiality was a term a few British sportsmen used to describe how hunting was no longer natural. The

\footnotetext{
232 Ibid, xi.

${ }^{233}$ Mrs. W.W. Baillie, Days and Nights of Shikar (London: J. Lane \& Co., 1921), 70.

${ }^{234}$ Nicholls, Assam shikari, 27.
} 
demand, as well as the craze for game, led to more artificial methods of shooting as game animals were reintroduced into the wild. In Fifty Years of Sport, E.D. Miller writes that Moosohurs and Donghurs "supply the planters with game birds of all kinds, such as snipe, duck, quail etc., which they capture alive in nets. The duck and quail are put into specially constructed duckeries and quail houses, and are fattened up and till the shooting season is over, so that planters were able to get delicious game practically through all the hot weather. ${ }^{235}$ Miller refers to tea estates managers or factory owners living near Motihari, Bihar. Surprisingly, the very people who were providing game to the British were actively undermining the $R a j$. The Mosohurs are described to be low-caste individuals who were active in dacoity and petty theft by the Inspector-General of Police Lower Provinces of Bengal. ${ }^{236}$ Even though they were shikaris in their own right they also served as beaters for pigsticking events arranged by large planters. Moosohurs and Donghurs therefore did the hardest work of the shoot by locating game and literally bringing it within arm's reach for the British. Furthermore, hunting with nets was acceptable provided they were obtaining game for the British and not for themselves. Under ordinary circumstances the British would have classed the Moosohurs and Donghurs as poachers, but in this case they tolerated those methods because smallwinged game was a delicacy for British tables. As big factory owners or managers of tea

\footnotetext{
${ }^{235}$ Lieut. E.D. Miller, Fifty Years of Sport (London: Hurst and Blackett, Ltd., 1925), 107.

${ }^{236}$ Lt.Col. J.R. Pughe, Report on the State of Police in the Lower Provinces of the Bengal Presidency for the Year of 1867, Vol. 1 (Calcutta: Thomas Smith Press, 1868), 110.
} 
estates, there were few instances when shikar took them far away from their residences.

Just as in Britain during the turn of the century, shikaris replaced the duties of gamekeepers who managed artificial rearing of game such as partridge, and pheasants. In addition to sport, the game that was reared in the duckeries and quail houses served the dual purpose of appeasing the stomach and trigger happy index fingers of British males.

\section{Differentiation of Indians}

By the $20^{\text {th }}$ century, the British believed they had a duty to uphold honor in Indian hunters and by extension uphold the worthiness of the title of sportsman. While there was some indifference in the $19^{\text {th }}$ century among British sportsmen about killing female and baby game, most sportsmen did restrain themselves from shooting female and baby game. However, by the $20^{\text {th }}$ century a sportsman's reputation was at stake if he did not follow game laws and status quo of fixing a huge male trophy as one's prize. Hunting etiquette in the $20^{\text {th }}$ century demanded that only mature male game were killed at the hands of the hunter. A British sportsman gave a short lecture to a syce or horse groomer's son after he had killed a sow. E.D. Miller's brother told him "he was never to kill a sow again if he values his reputation as a sportsman, whereupon he was very sorry." 237 This exchange shows the remorse of the young Indian man and emphasizes the triumph of the British in their teachings that were disseminated to their Indian subordinates. The feeling of guilt and wrongdoings represented the success of the mission.

${ }^{237}$ Lieut. E.D. Miller, Fifty Years of Sport (London: Hurst and Blackett, Ltd., 1925), 107. 
It was automatically assumed that tribals did not have a conscience regarding the killing of game. This was another common tool that the British used to demean tribal shikaris. F.W.F. Fletcher states in a letter to Charles Kofoid the requirements for hunting in the Ghat forests. He asserts that in order to legally hunt in the Ghat forests, a license is needed from the collector of the Malabar coast. Fletcher, who resided in the Nilgiri Hills writes "I know shikaris who are without my scruples, who would jump at the chance of shooting an elephant if you can get the necessary license." ${ }^{238}$ The emphasis in this quote is on my scruples, which helps differentiate other Indian shikaris from British sportsmen, who had reservations against some forms of hunting. Indian shikaris allegedly did not have second thoughts about killing an animal like an elephant - an animal that did not pose a danger to people, that helped with transportation purposes, and was not a "sportful" shot. Hunting elephants was also against the law, unless it was a rogue elephant and permission was granted to shoot it.

In reality, shikaris were just like every other human being. Shikaris did not just enjoy shooting randomly. They did have a conscience just like everyone else. While that is not expressed from their writings, accounts by British sportsmen relayed the thoughts of some of these shikaris and their families. Tribals were often depicted as meat hungry and people who have no reservations against killing animals because they were not knowledgeable about religion from the shastras or law books. Christopher writes that "Relatives and friends will try all in their power to dissuade him from taking life"

\footnotetext{
${ }^{238}$ Letter. FWF Fletcher to Charles Kofoid. 18 ${ }^{\text {th }}$ May 1916. Charles Atwood Kofoid Correspondence. Banc MSS 82/39cz UC Berkeley Bancroft Library.
} 
suggesting that they know that it is morally wrong to hurt another living being. ${ }^{239}$ Hunting was not a sport to these tribals for they clearly understood the dangers of what they were doing and what their family members were engaging in.

British sportsmen also differentiated themselves from Indian shikaris. British sportsmen emphasized the determination and will that they possessed which made them superior sportsmen because they never gave up on trying to bag an animal (even if they missed killing the animal the first time). Hunting etiquette did not customarily allow for sportsmen to leave wounded animals because it would ruin another sahib's sport. James Best writes of the superior nature of British sportsmen as he states: "I could quote three instances from after years, when by going out myself next day after a wounded beast I succeeded in bagging him, when all the natives had given up. The reason is that a native's patience is child-like...It is the will of Allah." ${ }^{240}$ Muslim shikaris, according to Best, believed it was not meant to be if they did not seize the animal as it was their fate. There was no resolve among Muslim shikaris who understood that if they did not catch the animal it was because God did not want them to, but there was a great sense of perseverance among British hunters mainly because they assumed that no animal was a match for them.

The British also emphasized that guns in the hands of Indians had led to the decline of game. Best writes that "The Mysore 'free' jungles were found bare of game in 1829, Khalifat Hills in Quetta had been poached clean of straight-horned markhor in

\footnotetext{
${ }^{239}$ Sydney Albert Christopher, Big game shooting in Lower Burma (Rangoon: Burma Pictorial Press, 1916), 68.

${ }^{240}$ Best, Forest Life in India, 27.
} 
1908." Best attributes the clearing of these jungles to the fact that "there are more native gunners in India than in Africa" and this is seen to be a problem. ${ }^{241}$ It is also important to highlight how it was automatically assumed that hunting by natives especially with guns resulted in poaching. Indians, according to the British, lacked an interest to protect dwindling numbers of game. This spelled a disaster for responsible British sportsmen.

Poachers who were mainly Indians did not question the labels placed upon them for not following hunting etiquette and hunting laws. By the $20^{\text {th }}$ century hunting associations took up preservation to the best of their abilities without restricting the hunting of their members. Poachers were the main target for pigstickers. Wardrop writes "Now for the poachers; they are the devil [....] kagis, sansis, aherias, ruffians all."242 Wardrop writes that all these tribal poachers are responsible for the decline of boars and therefore they harm the sport of pigsticking. Wardrop called all members to action. Members and other concerned sportsmen were to lobby the collector of the district and zamindars or landlords to help catch and reprimand the poachers. Indian elites were for the first time used to support preservation efforts. Pigsticking social organizations or tent clubs as they were called had a vested interest in preserving pigs for the good of the association. Tent clubs also had the exclusive rights to all pigs in the district for which the tent club as located.

While the British constantly denigrated Indian tribals and other Indian gunners for being poachers, the British continued to mimic certain elements of poachers' ways.

\footnotetext{
${ }^{241} \mathrm{Ibid}, 15$.

${ }^{242}$ Wardrop, A.E. Modern Pig Sticking (London: Macmillan, 1914), 214.
} 
Poachers often used non-traditional hunting methods because they were after a particular piece of an animal. Ivory from tusks led them to kill elephants or rhinoceros horns were used as an aphrodisiac. For example, the author of the Sportsman's Book writes that "Rhinocerous horn could also be used to make tables, lamp pedestals, and cigar boxes. ${ }^{243}$ Sportsmen clearly hunted for sport, however if they wished to get furniture for free then hunting a rhinoceros was the best way to accomplish that task. European luxuries and articles were possibly another secondary reason why the British hunted rhinoceros. Europeans clearly ignored the fact that they did use articles of the hunt for "subsistence" and chose to denigrate Indian poachers because there was a clear connection between their poaching and the money they received from selling valuable commodities from a dead animal.

The British were quite critical of poachers not only for these issues but also because the British wanted to distance themselves from the native peoples. As Thomas Metcalf states, differentiation was crucial to establishing the ideology of the $R a j$ and demarcating the subjects from the imperialists. This process began in the second half of the 19th century and by the 20th century it was crystallized. Anglo-Indians viewed the few villagers who had guns for their own defense and that of their agricultural produce and domesticated livestock as "bad shots" who only aggravated the game. Hunting was part of the identity of Anglo-Indian residents. C.E.M. Russell, a Late Senior Deputy Conservator of Forests in the Mysore service commented that "Sport, as distinguished from butchery, needs neither apology nor excuse; [as] the former is moderate and [a]

${ }^{243}$ Frederick George Aflalo. The sportsman's book for India (London: H. Marshall and Son, 1904), 64. 
humane exercise of an inherent instinct worthy of a cultivated gentleman, the latter the revolting outcome of the undisciplined nature of the savage."244 Another writer Augustus Somerville notes that hunting has been "characteristic of the white race."245

These statements show how the British viewed themselves as sportsmen, while

Indian tribals or village hunters were clearly not worthy of the title of sportsman.

Imperial masculinity evolves and differentiates itself from "savage," "native" men. Later,

Russell describes a poacher in the following manner:

Generally he possesses a gun - an antiquated, long-barrelled weapon as a rule... With his bare feet he can walk almost as noisily as a cat ; he knows every waterhole, salt-lick, and gale in the jungle near his home...together with his intimate acquaintance with the habits of the game, added to an unlimited store of patience, and a total disregard of the value of time There are many other human poachers, particularly gypsy-like wandering tribes who do not use guns, but who are extremely expert in every conceivable device for capturing game, both large and small... of a tame buck with nooses fastened to his horns ... By this method, bucks only are taken, but another plan for the wholesale capture of the animals, without regard to sex or age, is practiced with only too much success in parts of Mysore. A large number of natives, each with a long cord, to which at intervals nooses of strong gut are attached, proceed together to a place towards which [...] The cords are then firmly pegged down in a long and often double line and the men by making a very wide, circuit, endeavour to get round the herd...should the operation prove successful, several of the animals are often caught by the legs, and promptly butchered by the poachers. ${ }^{246}$

These were Indians who according to Anglo-Indians did not have any etiquette, moral

\footnotetext{
244 Charles Edward Mackintosh Russell, Bullet and Shot in the Indian forest, plain and hill. With hints to beginners in Indian Shooting. (London: W. Thacker \& Co., 1900), 1.

245 Augustus Somerville, Shikar near Calcutta : with a trip to the Sunderbunds (Calcutta: W. Newman, 1924), 1.

246 Russell, Bullet and Shot, 347-348.
} 
restraint or display any sportsmanlike character. Russell communicates an ambivalence towards poachers as the barefoot, quiet, expert qualities of shikaris were cherished, yet the lack of restraint, the apparent disregard for animal torture, and use of non-traditional methods were condemned. Furthermore, they did not practice the long, cherished stalking process or the European style of hunting with a gun. Notions of racial difference are quite evident in this passage. The lack of guns, the extreme torture to the animals, and the lack of discrimination of sex were seen as problems by many Anglo-Indians. The British condemned the indiscriminate shooting of female game animals because reproduction and breeding would not be able to occur and this would lead to an inevitable decline in those affected species. This led to the Wild Birds and Animal Protection Act of 1912 which stated that females of gooral, serow, buffalo, bison, deer, antelope and bird could not be killed during some parts of the year. ${ }^{247}$ Indian poachers on the other hand seemed to ignore this ruling.

The inhumane methods of killing animals broke the unwritten code of etiquette that sportsmen followed. The savage hunter was painted as an Indian tribal or shikari who tended to "butcher" their game by inflicting painful methods of death such as pelting stones at the animals, capturing in snares, nets, poisoned arrows, poisoned bait or any other similar fortune. Similarly, excessive shooting of game was seen as a lack of restraint which did not allow the sportsmen to hold the title of a "gentle and tender

247 Somerville, Shikar Near Calcutta, 111. 
hearted" man. ${ }^{248}$ The gentleman was the new sportsman who was the sportsmen that others had to aspire to be. Previously, in the $19^{\text {th }}$ century, British sportsmen shot game at salt licks and they viewed their intimate knowledge of natural history as a benefit to the sport. In the $20^{\text {th }}$ century there was a shift in hunting etiquette according to which hunters should have to stalk the game rather than simply shooting the animal when it was at a salt lick and an easy target.

The British also emphasized the bad marksmanship and the lack of knowledge Indians possessed with regards to shooting from a gun. Their guns were clearly of inferior quality as Russell describes them as "antiquated." They tended to wound rather than kill the animal. The British did not like to shoot at animals that had been shot at before because it gave the British the upper hand in the hunting arena and fairness was the main motto of the hunter in the $20^{\text {th }}$ century. Poachers had an infinite amount of time to hunt because they had no real job unlike respectable Europeans who did not hunt for a livelihood. Sport did not take up a respectable man's entire life, however it did take a few hours of his time on specific excursions or several days should he be an enthusiast.

\section{New Technology and Improvements in Hunting}

In addition to the Indian servants, by the mid-20th century, photography was commonly combined with the hunting experience. A camera became a must, because many wished to capture the looks of a tahr (Himalayan wild goat) or gooral (another type

248 Russell, Bullet and Shot in the Indian forest, 1. 
of goat), the scenery, and also the "strange looking natives." 249 Voyeurism of natives was a common activity and photography helped document it for Europeans back in Britain. Classification of people followed voyeurism. As Bernard Cohn has mentioned, this documentation and classification of objects in the Indian subcontinent was a form of domination. $^{250}$

Nostalgia for the countryside was evident in most British sportsmen's books. Many European sportsmen emphasized the grandeur of nature's delights. Beautiful scenery could be enjoyed during the hunting expeditions. Describing the beauty of the terrain was essential for publishing these memoirs as well as relating the magnificence of India's environment. Colonel Glasfurd of the Indian Army stated that experience outdoors while hunting for game was quite majestic. He describes it as a tropical paradise. He writes "the air is fresh up here in this high-lying glen, full of eucalyptus, like scent that rises from the dry-topped grasses through which a tiny footpath passes to plunge into an edge of dense jungle beyond a couple of aola-trees, their drooping branches heavy with pale-green fruit." ${ }^{251}$ Along with the gorgeous scenery was the enormous pleasure that hunts gave to the hunters. In their books, many Anglo-Indians mentioned how hunting and residing in the country was one of the happiest times of their

\footnotetext{
249 Ajax, 'Good hunting!', 29.

250 Bernard Cohn, Colonialism and Its Forms of Knowledge (Princeton: University Press, 1996), 3.
}

251 A.I.R. Glasfurd, Musings of an Old Shikari (Delhi: Natraj Publishers, 2001), 254. 
lives.

Natural history was intricately connected to the hunting experience. Wardrop commented on how pigs had rather good eye sight. ${ }^{252}$ Discussions of natural history often included informing the reader about the animal's Indian name, its Latin name, a little background about its species, where its primary habitat was, and a little about its character. The description often sought to educate and satisfy the reader's curiosity. A typical entry is appended here:

Pigmy Hog (Porcula Salvania): This tiny animal, which is said by Mr. Hodgson to resemble in size and shape a young one of the preceding species[pig] of about a month old, weighs only from seven to ten pounds. Its habitat is the saul forests of Sikkim, and the Nepaul Terai....The vernacular names for this animal are Chotasoor. According to the same author, the pigmy hog goes in herds, and the males will courageously attack intruders. ${ }^{253}$

This information would also be published in the gazette of Bombay Natural History.

The ordering and classification of animals can be regarded as an imperial trait that became part of the Anglo-Indian character to understand the world that they were living in. This was another way of controlling and ordering the classification of animals..$^{254}$

By the $20^{\text {th }}$ century, there was a large following of men who had strong feelings of nostalgia for a past time when it came to viewing tribals whom they often met when hunting in the jungles. The British had made great advances in education and missionaries had worked tirelessly to convert many tribals to Christianity. Therefore,

\footnotetext{
252 Stockley, Shikar, 32.

253 Russell, Bullet and Shot, 345.

${ }^{254}$ Cohn, Colonialism and Its Forms of Knowledge, 5.
} 
tribals who still retained "elements of savagery" especially those who had not yet converted to Christianity were often sought after. James Best writes of his time in Bilaspur district in 1905 when he states "I consider myself lucky to have seen as much of these people as I did before they too, are spoilt by our civilizing education and turned from truthful and natural savages into imitation Europeans." 255 This is interestingly the same nostalgia that British hunters in Britain felt when they championed foxhunting for the return to country life and its customs and mores after the debate on whether foxhunting was a cruel sport.

Another reason for the disdain for modernity was the consequences of tribals' conversion to Christianity. While this did not necessarily translate into an end to hunting, tribals did make some changes to their old routines. Sydney Christopher, a Barrister at law in Lower Burma, writes that the Karens who had converted to Christianity "became stubbornly bigoted, and will not accompany a shooting expedition on any account on a Sunday." 256 This was a real frustration for many British sportsmen who liked to hunt on their days off from work.

Furthermore, being a part of the tribal's life by participating in shikar together made more British sportsmen knowledgeable and even expert anthropologists on tribal customs and languages. James Best writes that "here I was working with a party of Gonds and took the opportunity to learn a few words of their language, which amused them intensely." 257 Part of the Anglo-Indian project for many sportsmen was to become

\footnotetext{
255 Best, Forest Life in India, 82.

${ }^{256}$ Christopher, Big game shooting in Lower Burma, 67.

257 Best, Forest Life in India, 86.
} 
conversant in vernacular languages for sporting purposes. Therefore, the quest to learn Indian languages arose not out of a genuine interest in native culture, but purely instrumentally, to help their hunting.

There was a lot of misinformation floating around among British circles about tribals. Blanket statements which tended to categorize the tribal as a savage man were examples and reflections of this attitude. Many of these men were not familiar with tribals but felt they had the expertise to comment upon them from merely living in India. Other men were familiar with one tribal group and wrongly assumed that other tribals would be the same. Some British sportsmen took these false insinuations to heart and made an effort to correct statements that were wrong. James Best writes that "I have lived the best years of my life among the jungle men of the C.P. [Central Provinces] and I have never seen one of them throw his axe at a bird or animal." ${ }^{258}$ Best's nostalgia for the Gonds was one reason he took it to heart to clear the incorrect published accounts on Gonds. Axes, Best writes are used for a variety of functions, but not to hunt animals. They were used primarily in the cutting up of meat.

Photography was also commonly used to depict the hunt as a 'grand experience' or one that documented man's control over nature. The most common hunting pose was one in which the foot was placed over the animal's carcass prior to the skinning process. This essentially represented the man's power over the animal. Photography was also used typically to document the extraordinary size of the animal that was 'bagged' to show others one's trophy. Men were often quite proud of larger animals that they 'bagged.'

${ }^{258}$ Ibid, 85. 
Trophies have been associated with the compulsion to exhibit one's manliness. As Tina Loo has stated in her deconstruction of the trophy, it is a masculine object as well as a masculine project to obtain it. ${ }^{259}$ Trophies are symbols of masculinity and displaying them psychologically triggered the great feat of the man as he conquers a dangerous beast. New technologies such as telescopes were incorporated into the hunting grounds in order to magnify the animal in view and get a better shot at it. ${ }^{260}$

\section{Paternalism}

Paternalism and a sense of masculine responsibility can be discerned from the Anglo-Indian hunting experience. Mrinalini Sinha writes that "the real test of British masculinity was in the 'chivalric' protection of white women from native men."261 The other test of British masculinity was in protecting Indian men and women from dangerous game. Frank Nicholls, an honorary game warden of Assam’s Forest Department, often had villagers come to him to request a shooting of animals that destroyed the rice paddies or to report khabbar or news of tiger sightings. ${ }^{262}$ One of the chapters in Assam shikari captures the spirit of how paternally-minded British felt about

\footnotetext{
259 Tina Loo, "Of Moose and Men: Hunting for Masculinities in British Columbia, 1880-1939," Western Historical Quarterly, Vol. 32, No. 3 (Autumn 2001): 298.

${ }^{260}$ Henry Lawrence Haughton, Sport \& folklore in the Himalaya (London: E. Arnold, 1913), 148.

261 Mrinalini Sinha, Colonial Masculinity: The 'Manly Englishman' and the 'Effeminate Bengali' in the Late Nineteenth Century (Manchester: University Press, 1995), 51.

262 Nicholls, Assam Shikari, 17.
} 
dangerous game with the title "Sala Bagh." Sala is a crude swear word and is representative of the attitudes that certain sportsmen who would hunt to protect the community, which could be a pestilence for tea plantations and for local officials who had to protect their districts and subordinates from the depredations of wild animals. It was an imperial guarantee that the British promised to their subordinates, however it was one that weighed heavily upon their bodies and minds. An active role in the community as a protector was another facet of the British sportsman.

In order to maintain the honor that a sahib must uphold, guns had to be carried at all times. This was recommended of all well-rounded sportsmen in British India. Sahibs were supposed to walk around with guns in order to protect the natives from dangerous animals like tigers. Killing a tiger or any other large animal was seen as an honorable thing to do. The sahib writes that a man without a gun cannot kill a tiger and then this incident "greatly [lowers] the izzat of the sahib in native eyes." 263 Izzat translates to honor. Therefore, to uphold the honor that is due to the sahib, laziness must never prevail and a gun must always be on hand. By the $20^{\text {th }}$ century a lot of Indians owned guns themselves. Nevertheless Indians were still dependent on the British to protect them from dangerous animals.

Jim Corbett was one of the most renowned British hunters, conservationists, and naturalists of the $20^{\text {th }}$ century. He was also a paternalistic hunter. Corbett developed a great sense of conservationist feelings and was instrumental in the creation of Corbett

\footnotetext{
${ }^{263}$ Frederick George Aflalo, The sportsman's book for India (London: H. Marshall and Son, 1904), 19.
} 
National Park in 1935 in the Nainital and Pauri districts in North India. Although Corbett was a hunter, his views changed radically after witnessing first-hand the depredations on villages caused by tigers. Corbett later chose to hunt only man-eating tigers. Corbett was one of the first to attempt to explain why tigers chose to kill and eat humans. This approach would later be followed by Indian hunters and Indian conservationists who attempted to give a reasonable explanation that did not brand tigers as bloodthirsty animals but rather as animals that needed protection.

Corbett explained in his 1946 book, Man-Eaters of Kumaon, that wounds and old age tended to make tigers man-eaters because these conditions weakened the tiger, which would then resort to easy prey - people. Other reasons that led tigers to kill men and women are the loss of typical prey like deer because of human encroachments on forest habitat and declines in deer or other fair game. Excessive deaths of humans due to epidemics like cholera also attracted man-eating leopards who grew accustomed to the taste of dead humans and then sought to kill live humans. ${ }^{264}$ The lack of proper cremation of bodies in times of epidemics led to the piling up of bodies, which attracted other man-eaters like leopards. By explaining these animals' attacks on people this way, Corbett moved away from the tradition of blaming the tiger to a more modern ecological approach, a move later employed by conservationists. Corbett refers to the tiger as a "large-hearted gentleman" and this phrase is representative of decades of imperial

\footnotetext{
${ }^{264}$ Jim Corbett, Man-Eaters of Kumaon (Bombay: Oxford University Press, 1946), xix.
} 
connections to tigers as the rajas of the jungles. It also parallels the notion of the gentlemanly hunter, reinforcing the notion to the hunter that hunter and prey are worthy opponents.

The distress caused by man-eaters is evident in the many stories that Corbett includes in his book Man-Eaters of Kumaon. The Champawat tigress of Kumaon had killed 200 people in Nepal and 234 in Kumaon. ${ }^{265}$ Before shooting the tigress, Corbett made it clear that he wanted the government reward for killing the tiger void because he did not want to be "classed as a reward-hunter." He wanted to be viewed as a hunter who hunted for the good of people thereby displaying a great sense of hunting etiquette and serving the Empire as a gentlemanly sportsman. The case was so bad that people feared to go outside into the village. Villagers readily cooperated with Corbett and gave him information about the tiger and he studied the clues the tiger left behind while searching for footprints and other details. Corbett was a godsend to the villagers because of his courage in dealing with dangerous animals and his effectiveness in protecting the people. His presence alone gave villagers the peace of mind to continue their daily farm chores. Wheat was cut by villagers only after Corbett stood among them as a guard. ${ }^{266}$ The gratitude expressed by Indians for Corbett's efforts was quite deep and sincere. One woman bent down to touch her hands to Corbett's feet- a traditional sign of respect and

\footnotetext{
${ }^{265} \mathrm{Ibid}, 4$

${ }^{266} \mathrm{Ibid}, 7$.
} 
deferment to one's elders. ${ }^{267}$

Corbett was not alone in his effort to help kill man-eating tigers. Local elites did their best to assist the sportsman in his efforts. In the case of the Champawat man-eaters the Tahsildar or Chief Revenue Officer provided Corbett accommodation in a bungalow. Corbett initially began his hunt for man-eating tigers after hearing stories of the deaths of local villagers and also by request of the Government. The killing of the Champawat tigers began on request of the Deputy Commissioner of Naini Tal. While the sahibs, or in this case Corbett, took much of the credit for bravely killing the man-eating tigress, the government did display a sense of appreciation for the efforts of Indians in helping exterminate the man eater. Sir John Hewett, the Lt. Governor of the United Provinces offered the Tahsildar of Champawat a gun and a knife to the village man who assisted Corbett at a durbar in Naini Tal. ${ }^{268}$

As representatives of the empire, British officials were obligated to maintain the general welfare of their particular district and in many cases they were personally motivated to do so because they genuinely wanted to help villagers who were quite helpless and much more unfortunate than themselves. J. E. Carrington Turner, the Divisional Forest Officer of Naini Tal, part of Kumaon and home to several maneaters not only helped take revenge against man-eaters, but livestock killers as well. At the death of a pair of bullocks, he bicycled for five miles to his home to get a gun

\footnotetext{
${ }^{267} \mathrm{Ibid}, 13$.

${ }^{268} \mathrm{Ibid}, 32$.
} 
and went after the cattle killer for he knew the value of bullocks to a villager and knew that he would be at a loss without them.

A strong sense of personal ethics often restrained hunters from unnecessary killings. Turner was one such individual who had a strong sense of resolve and determination that resembled Jim Corbett. On one occasion, Turner asked priests in Mahableshwar about whether the tiger lurking in the area was a man-eater and their reply was no. He instantly asserted that "in that case I can see no reasoning for killing him. The animal is following the natural pattern of his life, hunting his prey in the forest, and so reducing the damage done to your crops by deer and wild pig. Such an animal must surely be regarded as a protector of your livelihood."269

The quick action taken to avenge the killing of a human being was most pronounced by district officials who worked at hasty speeds to catch up with the maneater and deliver justice on the spot with a gun at hand. At the first news of the death of a villager, Turner packed sandwiches along with biscuits and instantly went to the scene. Turner describes how he walked seven miles with two other Indian helpers at an extremely fast pace. Turner did not foresee coming back until the man-eater was gone. Upon arriving at the scene, questions were asked about information of the maneater. Then a general search commenced in the forests to track the tiger.

Wherever a British official went local villagers usually barraged him with requests related to animals and hunting, such as taking revenge on a man- eater, administering medical care or acquiring meat for them. For example, Turner

\footnotetext{
269 J.E. Carrington Turner, Man-Eaters and Memories (London: Robert Hale Ltd., 1959), 14.
} 
describes how Maratha villagers who lived adjacent to forests near Mahableshwar asked him to shoot a pig for them, so that they could eat it and use its fat for medicinal purposes. Turner did kill the pig and after its death there was great joy. The task of the British official was to ensure that everyone received their fair share thereby demanding an equitable distribution of meat. Similarly, if a British man was simply standing in the presence of an animal attack or intrusion, local people expected that he would compensate them for losses incurred by that animal. After a bear ate grain stored in a villager's house, pandemonium broke out until Turner offered compensation for the grain that had been eaten by the bear.

As Jim Corbett often related in his man-eating tiger stories, work remained at a standstill when news of man-eating tigers abounded. It was therefore the duty of forest service officials to ensure that felling of trees occurred and construction efforts continued, and that usually meant that the man-eater needed to be killed, so that large cities like Bombay could have their supply of timber and development of new bungalows could go unobstructed. British officials had an equal interest in stopping the man-eater or cattle killer to protect the general welfare of their districts. Just as villagers demanded compensation or revenge and took their loss personally as the rightful owners of livestock or relatives of a person that had been killed so too did British officials whose sense of ethics and paternal qualities were seriously challenged when nature decided to interfere with a British man's district. Turner writes how he "was outraged by the sudden loss of this young thing and determined 
to shoot the killer."270 Turner was referring to a baby camel that had been killed and as camels were indispensable for transportation, the loss was particularly moving. British men also gave their word that they would find the man-eating animal. Turner gave his word that he would locate and kill a man-eating leopard to Narbat Singh, and upon the death of the said leopard of Chowkooree was sure that the man's spirit would rejoice after he killed the leopard.

Sportsmen in the $20^{\text {th }}$ century, similar to the $19^{\text {th }}$ century continued their roles of serving as medical doctors to Indians, when on shikar. "Kildeer" writes in his Timely hints to Shikaris that castor oil, Epsom salts, quinine, permanganate of potash and lime juice are extremely important to keep on hand as medications. ${ }^{271}$ They should be given to Indian servants if they are sick with such illnesses as bowel disorders or fever. Taking care of Indians was part of the imperial duty that sportsmen encountered and many diligently saved countless lives. Indians typically did not go to the hospital when sick and often died. The British paternalist sportsman made sure Indians under his watch were treated and their survival rate rose dramatically.

Paternalism also meant to take care of the Indians and be a responsible imperial model for one's subsidiaries. Sydney Christopher writes "you are not expected to regale them with spirits, nor is it a practice I would recommend as a sportsman [...] Shans are particularly fond of strong drinks $[\ldots]$ and will drink themselves to stupefaction if given the opportunity." ${ }^{272}$ The British needed alert shikaris and alcohol would prevent shikaris

\footnotetext{
${ }^{270} \mathrm{Ibid}, 127$.

${ }^{271}$ Kildeer, Timely hints to amateur shikaries (Madras: Higginbotham \& Co., 1909), 11.

${ }^{272}$ Christopher, Big game shooting in Lower Burma, 65.
} 
from being alert. The British also believed that they had the responsibility to emphasize righteous behavior among the tribals. Even though tribals in Burma such as the Shans drank alcohol, the British had an imperial responsibility to protect the Indians from dangerous behavior and avoid instances where a drunk Indian man might not appear subservient to the British.

Credit for the killing of wild animals was customarily given to the British though Indian shikaris and coolies did most of the work that goes into bagging an animal. In The Asian, a newspaper that was circulated in Rangoon, Burma, it was stated: "Mr.

Christopher Barrister at law has killed another tiger $7^{\text {th }}$ November 1903 Two sportsman went out to shoot bison last Sunday, a few miles out of Rangoon, and one of them had the good fortune to kill a fine young male tiger measuring 8 feet." ${ }^{273}$ Shikaris are not mentioned whatsoever in the account even though we know Christopher always used shikaris. The shot fired at the tiger takes precedence over tracking the tiger, setting up of a machan or platform, and finding the tiger - all necessary activities of an Indian. The British were clearly represented as men who protected the lands and got rid of dangerous animals.

\section{Regal Hunts}

Regal hunts flourished during the $20^{\text {th }}$ century, however they can hardly be categorized as arduous hunting. They are clearly imperial and ceremonial in nature. One particular royal shoot in the princely state of Bikaner hosted by none other

\footnotetext{
${ }^{273}$ Christopher, Big game shooting in Lower Burma, 148.
} 
than the Maharaja of Bikaner included Capt. Dudley North, Capt. Poynder, Kumar Sri Bhawani Singhji, Mr. Percival Landon Col Boileau, Maharaj Kumar, Maharah Jam Sahib, Col. O’Kinealy, Lord Louis Mountbatten, Prince of Wales, Sir Philip Grey Egerton, and Capt. the Honorable Piers Legh. These important grandees and dignitaries were given the royal treatment at hunting camps with servants galore.

Aristocrats as well as senior government or military officials were often privy to royal shoots. A royal shoot or hunting expedition resembled a regular shoot but also involved large numbers of servants, a retinue of the staff of the maharajahs as well as large numbers of shikaris and coolies. Such large numbers of servants and gurkhas to act as guards were necessary in order to facilitate enormous bags of game. Royal shoots typically involved big and small game shooting. In the $20^{\text {th }}$ century, Indian princes would often celebrate the visit of a figure from the British royal family or other titled men by hosting a regal hunting expedition for them. Nepal often hosted royal shoots in the Terai, a preserved game tract.

Because of the large number of servants and the goal of big bags to commemorate a royal shoot, these shoots were often more staged than regular shoots. For example, during a hunting shoot at Kodamdesar on December 3, 1921 an artificial tank and fake cranes were placed at the shooting site. Real cranes were then attracted to the artificial water source. Servants also informed the shooters when cranes were close enough for shooting so all the shooter had to do was point his gun at the crane and shoot. Men did not have to engage in actual hunting for when the crane was close enough they could 
easily shoot as this type of hunting was akin to target practice. For the elites, in the early $20^{\text {th }}$ century, there develops a more civilized or gentlemanly masculinity, which is showcased in the regal shoots. In this manner shooting commenced in the mornings when birds frequented a pond or stream to drink water. Similarly, when Lord Hardinge shot, an Indian man was placed in his charge " whose task it was to count the birds [he] shot." There were also some "fine young Indians, almost naked" whose job was to collect all the ducks he shot to bring to the viceroy. ${ }^{274}$ Large bags were obtained during royal shoots, more so than in regular shoots of small game. The Prince of Wales' party shot 1,006 imperial sand grouse, 6 ducks, 262 sand grouse. ${ }^{275}$ This was much more than the hundreds which were generally bagged at regular shoots. Shooting was not limited to just one day but typically continued for a week. On December $5^{\text {th }} 1921$ more modest large game bags in Gujner and also in Bikaner were obtained. For example, Lord Louis Mountbatten shot only four chinkara or gazelle and the Prince of Wales shot two black buck and chinkara on December 6, 1921 in Gujner. ${ }^{276}$

Native experts were also in attendance during royal shoots. One such expert was N.A Baptista, a Goan man who was recommended to the Prince of Wales by the Bombay Natural History Society. Baptista was a man who was a specialist skinner. He also had the ability to speak different languages other than his mother tongue, Konkani. This was a technique that many shikaris or those that worked with game possessed. Baptista, who was most likely a Catholic, spoke Nepali and was given permission by the Maharaja of

\footnotetext{
${ }^{274}$ Baron Charles of Penhurst Hardinge, On hill and plain (London: Murray, 1933), 39.

${ }^{275}$ Bernard Cuthbert Ellison, H.R.H. The Prince of Wales's sport in India (London: W. Heinemann, Ltd., 1925), 149.

${ }^{276}$ Ibid, 143.
} 
Nepal to acquire specimens for the British museum and the Bombay National Historical Society. ${ }^{277}$ Baptista served in the Prince of Wales party as head moochie or skinner overseeing the animals for trophies.

Shikar served as a way to facilitate British-Indian diplomacy. The main parties involved in the diplomatic process were Indian princes and the British royals or other members of the British elite such as titled men, both those from Britain and those posted in British India. Shikar took place in the game preserves of the princely states. Shikar was followed by a banquet. The cordial stately lavishness that occurred during royal shoots can be deconstructed from the programs that were printed for a royal shoot, which explained the opening procession followed by the highlights of each hunting day. The beginning of a royal shoot often opened with an important personage such as the Prince of Wales riding on top of an elephant in Gwalior.

Without Indian maharajas or princes, Anglo-Indians would not have been able to hunt in as grand a style with several servants, imperial troops, motor cars, cameras, biscuits, tea, drinks and cigarettes. Deer drives or drives of any other animals that were numerous in the princely states were also common. Deer driving was a process where all the deer were rounded up and brought to a common location where hunters would advance and shoot the animals in their presence. This was a traditional Indian practice. However it was mostly eminent British men such as Lord Hardinge who had the luxury of receiving repeat invitations to various Maharaja's palaces for the said purpose. Most Europeans however could expect to receive an invitation to the Maharaja's palace,

277 Ibid, 7. 
however it was more likely if one was higher up in the colonial service such as being a magistrate or a colonel in the Indian Army. These persons could partake in the hospitality that was bestowed upon them. The reliance on maharajas challenges the notion of wild game hunting as a sport that was commonly undertaken independently. Hunting in the company of elites was most often an imperial privilege. The institutionalization of hunting as an elite sport was an activity that brought Indians and the British together. It even helped solidify political alliances between Viceroys and princely rulers as in the case of Viceroy Hardinge who mentions how he hunted with the Maharaja of Bikaner. ${ }^{278}$

In the $20^{\text {th }}$ century, there were changing definitions of masculinity and ruthless killing of animals was increasingly frowned upon. Therefore, it is difficult to categorize the hunting in which they participated as a masculine activity in a traditional sense. This was generally the case for upper-class hunters, and not so much for hunters who organized their own hunting expeditions. For example, Baron Charles Hardinge noted how he "pursued chinkara [gazelle] in a motor car" 279 in the princely state of Bikaner in the North. Shooting by motor car became common for the elite in the 20 th century. The amount of masculine prowess, muscle, and energy required for the hunt was clearly minimal as humans had an unfair advantage over wildlife. This grand hunt however

\footnotetext{
${ }^{278}$ Hardinge, On hill and plain (London: Murray, 1933), x. $279 \mathrm{Ibid}, 8$.
} 
encapsulated the paternalistic, imperialist trait that was evident in the Anglo-Indian hunting experience. Anglo-Indians even of the upper-class tended to detest this organized form of hunting as it took some of the effort and adventure out of the hunt, however it nevertheless had its own form of excitement as many were amazed by how many animals they could kill in a short time and also on the ease with which they were able to get good shots. As the hunt becomes more staged and orchestrated the royal and elite British accept this because it is viewed as a "civilized way" to hunt in "style." Anglo-Indians of the upper class believed that they were skilled in hunting because they knew the methods, procedures and traditions of hunting. It was often assumed that Indian servants were not aware of the intricacies related to the hunting experience. For example, a British aristocratic hunter stated that he resorted to having his servant simply carry his rifle because the servant did not understand the "importance of the direction of the wind when stalking." ${ }^{280}$ The servant's lack of communication in English and knowledge about stalking procedures helped place Anglo-Indian hunters on a higher pedestal than Indian servants and shikaris. Hardinge also had experience hunting in Scotland. One man's view does not contradict the majority of sportsmen's beliefs that Indians were skilled and possessed hunting knowledge.

While maharajas attended pigsticking events, the British royal and premier elites did not. While the British ruling elite found small and large game shooting acceptable, they did not see pigsticking as an acceptably elite sport. Lord Hardinge participated in a

280 Ibid, 25. 
pig sticking event with the Maharajah of Bikaner on the $15^{\text {th }}$ of December in 1912. After that pigsticking meet, Hardinge writes "I regret to say this was my last experience of pigsticking as an account of my fight with this pig having been described in some newspaper in England, I received a message from a high quarter asking me to abstain in future from this form of sport." 281 Spearing a pig was viewed as a blood sport where the unrestrained passions of a man with a spear took out his revenge upon a fighting boar and was considered something unfit for a viceroy. It is difficult to determine whether elites participated in pigsticking events in the $19^{\text {th }}$ century because some tent clubs do not have $\log$ records for pigsticking throughout the century. By the $20^{\text {th }}$ century pigsticking was no longer acceptable for elites and it represented a civilizing in the hunt over time.

Generally, pigsticking was a pastime of Indian Civil servants and army staff.

\section{British sportsmen emulating Maharajas}

By the $20^{\text {th }}$ century, eminent British men served as patrons for men from the Americas and Europe, mimicking the rajas. An American hunter noted that Indians, excluding shikaris, rarely helped Anglo-Indians because they were "of no caste." 282 This most likely did not include elite British hunters such as Viceroys or Indian Civil Service servants. More often, village patels or headmen "simply laughed" or ignored the requests of European hunters when asked for coolies. ${ }^{283}$ Villagers' unhelpfulness meant that

\footnotetext{
${ }^{281}$ Ibid, 18.

282 William Hornaday, Two Years in the Jungle: the Experiences of a hunter and naturalist in India, Ceylon, the Malay Peninsula and Borneo (New York: Scribner's and Sons, 1904), 35.

283 Glasfurd, Musings of an old shikari, 24.
} 
Europeans had to depend on Anglo-Indians (British persons who served in the Raj). Village Indians had the ability to ignore requests of assistance without consequences. Others had to comply because in some locales sepoys or soldiers accompanied British sportsmen who held perwannahs or district orders that outlined the help necessary. Noncompliance did not make the hunt more exclusive or elitist. The reliance on Anglo-Indian hospitality was crucial. While Linda Colley has stated that the small numbers of Britons abroad in the 18th century led to vulnerability this was certainly not the case by the 20th century, as networks of contacts helped Anglo-Indians, Americans, and Europeans hunt with considerable amenities at their disposal. For example, William Hornaday, an American chief taxidermist of the National Museum, was dependent on Mr. Fraser, an Assistant Magistrate when he visited colonial India. Hornaday noted how Mr. Fraser accompanied him near the Jumna River and shot a five-foot gavial (a reptile similar to a crocodile that is currently endangered) and a big crane (endangered bird) and had several native boys skin them the following morning. ${ }^{284}$ The British showcased the subservient mentality and nature of Indians and displayed their imperial might to their American counterparts as they commanded their Indian servants to help with the hunt. Indians were crucial therefore for the menial "dirty work" that was necessary after the shooting of an animal. Upwards of 25 coolies were commonly taken along during the hunt for this said purpose.

284 Hornaday, Two Years in the Jungle, 36. 
British sportsmen served as conduits to foreign sportsmen, thereby emulating maharajahs and their lavish hospitality. The British would take foreigners from the Anglo world by setting them up with a network of contacts and introducing them to maharajas where necessary. The British in India served as repositories of information about game laws, types of game, licenses, and motor cars that were at the foreign sportsman's disposal. These informal partnerships between British and foreign sportsmen were critical to facilitate shikar. In some cases, researchers also contacted sportsmen to collect specimens. Charles Kofoid, an academic professor of Zoology at the University of California, shot his own specimens while hunting besides F.W.F. Fletcher, a British coffee planter. His request for specimens was sent to the Conservator of Forests, which granted his request. The letters exchanged between Fletcher and Kofoid help illustrate the desire to record their successful hunts. Fletcher writes to Kofoid stating "We ought to put a record of our jaunt into cold print. It was so successful that it would make good reading. If you write about it to an American paper, send me a copy of the issue in which your account appears. If you haven't time or the inclination to do this, let me know, and I will send the English "Field" an account." 285 Writing about the hunting narrative especially when it resulted in success, often translated into the triumph of hunter over the game. It also boasted the great skills of the hunter. The need to mark oneself as a successful hunter for posterity was also a driving force that helped demarcate the majority of British hunters from their Indian counterparts.

\footnotetext{
${ }^{285}$ Letter. FWF Fletcher to Charles Kofoid. 18 ${ }^{\text {th }}$ May 1916. Charles Atwood Kofoid Correspondence. BANC MSS 82/39cz UC Berkeley Bancroft Library.
} 
A subsequent letter that Fletcher, who interestingly published Sport in the Nilgiris and the Wynaad, wrote to Charles Kofoid represents the essence of the British sportsman - one that is not evident in the pages of his book. Fletcher writes "I will most gladly refund the University of California the money value of the tusks, if that body will make over the skull and tusks to me. And I am bound to say I felt rather sore at the revelation that you expected me to take all the trouble and [illegible] which the bagging of the animals you required in the limited time at our disposal involved, for no guerdon whatever in the shape of trophies." 286 The craze for trophies defined the quintessence of the British sportsman. Even though Fletcher had reservations against elephant hunting and did not engage in elephant hunting, he felt strongly about keeping a trophy of that elephant's tusk - the one he helped Kofoid obtain for his specimen. From deductive reasoning, we can assume that he probably did not have an elephant tusk, and believed he should have one since it was his labors and prowess that helped kill that elephant.

The vogue for trophies was characteristic of $20^{\text {th }}$ century hunts and led to intense tiger shoots even where tigers were not man-eaters. The main goal in bagging a tiger was to obtain a trophy after the death of the animal. The intense desire for a perfect trophy made excellent marksmanship a requirement. Shots which did not leave holes or marks in the skin of a tiger were preferred. Therefore, sportsmen sought to shoot tigers in discreet locations such as the ear in order to not ruin the skin for one's wall even if that meant putting themselves in harm's way. For hunters out on shikar, the primary motive

\footnotetext{
${ }^{286}$ Letter. FWF Fletcher to Charles Kofoid. $18^{\text {th }}$ May 1916. Charles Atwood Kofoid Correspondence. Banc MSS 82/39cz UC Berkeley Bancroft Library.
} 
was to bag as many tigers as possible in order to describe one's masculine prowess over the king of the jungle. E.D. Miller writes that "after we had accounted for our tiger" in the Nepalese Terai, small game shooting such as jungle and pea fowl could then begin.287 In the $20^{\text {th }}$ century, big game, particularly dangerous game remained a constant. James Best writes "ibex and shapu [urial sheep] should never be your main objectives. They are merely side-shows." 288 The gentle nature of these animals made them quite unfit to showcase one's masculinity, however their trophies were desired. Most sportsmen measured the animals they killed in their sporting books, letters and memoirs. The biggest animal, often a tiger, is also discussed in vast detail in sporting accounts.

Foreigners like many griffins or British men who just began their service in India oftentimes indulged in excessive hunting. These men took pleasure in the number of game they killed. Stella Benson, an American visiting the Sunderbans, writes that Frenchmen aboard a tourist steamship "unsportingly shot everything they saw...We simply left a dreadful trail behind us of wounded things - such lovely rice birds - thin and pure white - and herons and cranes and hawks and one immense tall bird with a black buck..."289 This excess was typical of the easy exploitation of Indian game by outsiders who felt no pity for the animals they killed one after another. This quote expands John MacKenzie's contention that the British were obsessed with hunting and shooting, to those of the larger European world. For many Europeans, shooting in British

\footnotetext{
${ }^{287}$ Lieut. E.D. Miller, Fifty Years of Sport. (London: Hurst and Blackett, Ltd., 1925), 117.

288 Best, Forest Life in India, 24.

${ }^{289}$ Letter. Stella Benson. Jan 26 $6^{\text {th }}$ 1921. Stella Benson Letters to Laura Hutton Banc MSS 2004/128cz UC Berkeley Bancroft Library.
} 
India was open to the rest of the European citizenry as laws were not believed to have been implemented because of the nation's colonial status.

\section{Conclusion}

The British sportsman in the $20^{\text {th }}$ century differed from the British sportsman in the $19^{\text {th }}$ century in that there was more restraint as female game were not killed and guns were customarily used. British recreation revolved around shikar as a sport as it was an integral part of the identity of British residents in India. The excitement and obsession for the hunt remained a constant in the $19^{\text {th }}$ century. While the British as the imperialists sought to control the Indian animals present in the forests and in other domains for paternalistic and personal reasons, they were nevertheless dependent on the native shikaris, servants or maharajas. While some British sportsmen praised their native partners and appreciated their expertise, many others did not. This shows the ambiguity of British attitudes, on the one hand derogatory and distrustful, and on the other praising and appreciative of local knowledge. The dependence on shikaris remained a constant, but in the $20^{\text {th }}$ century there appeared more distrust in the relationship between Britons and their Indian counterparts. By the $20^{\text {th }}$ century there appears to be a rise in gentlemanly masculinity that is dependent on Indians so that a British sportsman would simply have to have great marksmanship skills and pull a trigger, albeit outside in the hot weather. British hunters also differentiated themselves from Indian shikaris, especially the tribals who were distinguished from British sportsmen. Other major changes that 
occurred in the $20^{\text {th }}$ century resulted in a greater introduction of emotion, artificial rearing, technology integrated into the hunting process, and the appearance of humanitarian hunters who hunted to protect the community. The culmination of the Anglo-Indian tradition resulted in British sportsmen emulating Indian kings as they become patrons of European and American guests in order to display their power over Indian wildlife and their command over Indian laborers. While the British indulged in Indian methods of hunting such as becoming patrons of sport for others, they retained distinctively British methods of hunting etiquette. 


\section{Chapter 5: Indian Shikar: the Mughal successors -Indian princely rulers, Elite Indian Sportsman, and Tribal Hunters - Masculinity \& Challenging British Misconceptions}

Hunting was not solely the recreation of the British as Indians hunted as

well. Many Indians were avid hunters. There were three main types of Indian hunters.

There were the maharajahs or princes who hunted mostly following Mughal hunting tradition, Indian sportsman who often had college educations, and tribal hunters whose ancestral occupation was hunting wild game. The main argument of this chapter is that Indians used their own practices of hunting, but sometimes followed British ways. Hunters displayed a keen sense of masculinity. In addition, Indian hunting records challenge British misconceptions of Indian hunters. This chapter also adds to our current knowledge of hunting in colonial India since up to date there has been no systematic review of educated Indian sources of hunting.

While many memoirs of Indian hunters date from the $20^{\text {th }}$ century, Mughal records of hunting go back as far as the $16^{\text {th }}$ century. Indians began recording their hunting experiences for posterity, to share tips on hunting with others, and for recording grand feats as well as displaying pictures of their hunts in their published books. These accounts in many ways challenge British misconceptions of Indian hunters. 
These misconceptions generally involved the alleged lack of restraint on the part of Indian hunters. The similarities between Indian and British resident hunting in India explain the development of the Anglo-Indian tradition of hunting, which was a hybrid of Indian and British practices. Hunting for almost all Indian men, as it was for British men, was a way to express their masculinity.

\section{Mughal traditions}

After the excitement of the hunt, the Mughal regal tradition was to relax in the gardens and enjoy the quiet tranquility present in nature in the midst of flowers, greenery and the hot sun. ${ }^{290}$ There a party would generally follow, although the details of the party are not recorded. Mughal cuisine typically included several meat dishes that were products of the bounty of successful hunts. The princely successors to the Mughals similarly enjoyed game. For example, as Digvijaya Singh, the son of Raja Sir Dilip Singhji of Sailana writes in his Cooking Delights of the Maharajas: Exotic Dishes from the Princely House of Sailana quail and other game dishes often graced the tables of princely rulers. Such dishes included Khargosh ka Keema, which entailed making the game into minced meat and Soovar ki Saanth a specialty typically made out of wild boar. As previously reviewed in Chapter 2, the Mughals regal hunting tradition typically displayed excess although there was some sense of imperial benevolence that restricted random slaughter, bows and arrows along with swords were preferred over guns although that was not the case for later Mughals, animals were painted, poetry was written in

\footnotetext{
290 Babur Emperor, Babur-nama in English, trans. Annette Susannah Beveridge. (Britain: Stephen Austin and Sons Ltd., 1969), 424.
} 
regards to hunting, and hunting occurred in hunting circles.

\section{Indian Princely Rulers}

Indian princely rulers also enjoyed hunting as a pastime. Charles Allen writes that part of the Enlightenment of princely rulers was shikar and horseback riding. They also learned Western customs, which were part of the culture of aristocrats in Britain. Many maharajahs became "good shots" and hunting became an activity that they excelled in during their leisure periods. Shooting was recommended for all maharajahs in the General Policy Durbar meeting, which was presided over by Maharaja Madhavi Rao Scindia of Gwalior. The Nawab of Jaora even imported his own British hounds to hunt jackals in the plains of Central India. ${ }^{291}$ This section discusses hunting among the rulers of India under the British Empire including Nawabs and Maharajas from the late $18^{\text {th }}$ century to the late $20^{\text {th }}$ century.

Hunting as a regal sport was continued by the princely rulers of India who rose to prominence in the 19th century. Several maharajas, like the Maharaja of Bharatpur, excelled in the sport of hunting. The maharajas were also critical in helping host shootings for the British, since they opened their hunting grounds to various dignitaries. The maharajas were also crucial in lending elephants, an entourage, and supplies such as tents to help ensure the hunt would be regal and up to the standards required by the British. One particular Nawab Bahadur in the later 19th century, for example, brought as

\footnotetext{
${ }^{291}$ Charles Allen and Sharada Dwivedi, Lives of Indian Princes (London:Century Publication Associated with Taj Hotel Group, 1984), 130.
} 
many as 14 elephants and 80 coolies to a pig-sticking event as well as numerous tiffins of biscuits for snacks. ${ }^{292}$ An experienced hunter in India, Mr. Bruges noted that "it is scarcely possible for a traveller to engage in [hunting] unless he be the guest, as I have always been, of one of the Rajas." ${ }^{293}$ A sportsman needed a minimum of fifty elephants to shoot large game. Therefore, while the British emulated the practices of elite Indian rulers, ${ }^{294}$ they were not able to engage in the posh activity of big game hunting unless they had the auspices of a grand old raja. While most Europeans preferred the regal hunt as a statement of their superiority in India, there was also another type of hunting that was common in India.

Indian princely rulers had large compounds with numerous forests. In addition to khabbar or news of a wild animal's attack in localities where lions or tigers were numerous, a look-out station in the middle of the forest was usually set up. ${ }^{295}$ This information comes from Mrs. E. Barrett's Papers held in the Center for South Asian Studies in Cambridge. She is writing of the Nawab of Jaora and provides an in-depth look at how hunting news was transmitted in princely kingdoms. These look out stations were located in the most dense portion of the forest and informants would usually telephone the maharajah about the spottings of various game. In less technologically advanced

\footnotetext{
292 Raoul, Remiscences of twenty years 'pigsticking in Bengal (London: Thacker, Spink \& Co., 1893 ), 5.

293 Cleveland Moffet, "Hunting on Elephants in India - Interview," Pearson's Magazine VI (November 1898): 501.

294 John MacKenzie, Empire of Nature: Hunting, Conservation and British Imperialism (Manchester: Manchester University Press, 1988), 169.

295 Mrs. Barrett's Papers. Center for South Asian Studies. Cambridge University, 2.
} 
kingdoms, news would often be relayed by foot. The maharajah would then usually come by motor car to the location. It is not clear how they would arrive to the game in the $19^{\text {th }}$ century since I have not been able to find records for this information. In Udaipur, writes Charles Allen there were officers assigned to oversee beaters and officers in charge of hunting information.

Indian princely hunters did not always engage in excess and had some sense of restraint although that restraint was typically not due to environmental concerns, but rather personal or family reasons. Mrs. E. Barrett writes of the Nawab of Jaora, Ali Khan who did not hunt in a particular part of his forests because his great uncle was a jin or ghost who according to the Nawab lived in the form of a white blackbuck. ${ }^{296} \mathrm{He}$ also stated that he had seen his great-uncle several times before.

Like Mughal kings, maharajahs chose not to hunt after traumatic experiences. For example, Maharaja Dewar Junior stopped hunting after "killing a doe carrying a fawn." ${ }^{297}$ The Maharaja made the connection of the little fawn to a little baby and therefore understood that it was wrong to take a young one's life. The maharajah's ethics and beliefs were consistent with British sportsmen who strongly advised against the indiscriminate killing of does and fawns. Many British women also made the connection between fawns and little children and were against hunting that involved the killing of fawns or does as they were mothers themselves.

Although most British men and women viewed Indian Nawabs in terms of excess

\footnotetext{
${ }^{296}$ Mrs. Barrett Papers. Center for South Asian Studies. Cambridge University, 4.

297 Allen and Dwivedi, 144.
} 
and despotism, there were some Nawabs that were characterized as good sportsmen due mainly to their strong sense of restraint. Mrs. E. Barrett wrote that "H.H [His Highness the Nawab of Jaora], could have had as many tigers as he liked from the neighbouring States of Gwalior or Indore, but, fine sportsman that he was, preferred to shoot his own tigers in his own jungle.' ${ }^{298}$

Sri Bhupendra Chandra Sinha was a barrister at Mymensingh in Bengal. He earned a B.A. from Presidency College in Calcutta in 1919. He was also the Maharaja of Susanga. While it was common for educated Indians to take up the practice of hunting because they were emulating the British, Sinha clearly states that ever since he was a child he had always been interested in animals and the forests. Independent reasons for hunting are stressed among educated Indians. The British were not as much of an influence in directing Indian men's leisure sports as one would have thought, for there was an innate desire to hunt that was already cultivated in many of these men's hearts and minds. And as this chapter makes clear, there was a long tradition of hunting within Indian culture. As a child, Sinha loved to catch Doel birds and keep them in cages. ${ }^{299} \mathrm{He}$ writes that sometimes he caught as many as twenty of these singing birds. These birds were named Magpie Robins by the British after they arrived in India. His childhood instinct to trap small animals naturally drove him to the sport of hunting. Sinha hunted tiger, deer (harin), wild pigs, marsh partridges (kyar), rabbits, wild buffaloes, and all sorts of birds. Sinha also hunted in the Garo Mountains in the region of Bengal. He writes

\footnotetext{
${ }^{298}$ E. Barrett Papers. Center for South Asian Studies, Cambridge University, 2.

299 Bhupendra Chandra Sinha, Bana jangala o sikara katha (Bombai: Oriyenta Lammyansa, 1970), 6.
} 
that his journey to the mountains was one that "he remembers dearly, which is very close to his heart." ${ }^{\prime 300}$

Sinha's fascination with nature is evident in his description of the Sunderbans. In Hindi, the Sunderbans translate to beautiful forest. The Sunderbans according to Sinha was literally “a beautiful forest." His appreciation for nature refutes many British hunters' opinions that Indians did not understand the beauty of the wilderness. Sinha goes on to describe the Sunderbans as an "enjoyable scene" with the overbearing sky and mountains and lots of trees surrounding him and his elephant. Sinha also states that the forest was quite dense. He was not able to see anything more than eight feet in front of himself. The beauty of the forest reminded Indian hunters that forests belonged to God. In 1939, after receiving approval for his request to hunt in the Sunderbans, he hunted with a motor boat while in one of the lakes in the region. ${ }^{301}$

Sinha stressed the need for hunters to use sense (mantragan) not only to protect themselves but to successfully shoot an animal. Educated Indians almost always used air rifles both to protect themselves and successfully shoot game in the British fashion as opposed to the bows and arrows used by indigenous hunters. Indian hunters stressed prevention to help ensure safety while hunting. Sinha was always extra cautious and unlike British male hunters displayed a sense of uncertainty when hunting. Sinha wrote "I was thinking that in this deep forest even if we see a tiger how we can kill it"? ${ }^{302}$ These

\footnotetext{
${ }^{300}$ Sinha, Bana jangala o sikara katha, 21.

${ }^{301}$ Ibid, 129.

302 Ibid, 120.
} 
statements by no means challenged his masculinity, but simply highlighted his human side as he never challenged his capabilities, but rather the difficulty involved in tiger shooting in a dense forest. Like other hunters, Sinha states that there are certain areas that animals are almost always likely to be found. Random shooting was not the way that hunters should shoot game. Instead, hunters should use mantragan or sense to help locate game and then selectively shoot game. For example, nonamati soil or soil where mud is mixed with calcium deposits often have animals going there to renew their health. British hunters similarly disbursed tips to readers about endeavoring to locate saltlicks as a place to find abundant game.

Hunting also led to the bonding between tribal and educated princely people. As a sixteen year old boy, Sinha first met Junga. Junga, who was around 45 years old, was a tribal hunter living in the Garo Mountains. The Garo hunters were Christians, drank liquor, and hunted with tirs or bows and arrows. Sinha enjoyed to hear stories from Junga about the animals he captured. This friendly interaction between tribal and educated individuals was something that only a few British men experienced. Indians who were educated were more than likely to develop these friendships and gain access to the tribal life.

Like British hunters, Indian hunters typically classified animals they came across. For example, Sinha states that there are four different types of rabbits in the Indian subcontinent. He describes the brown rabbit as a rabbit who has fur which is very soft and makes you feel nice when you touch it. Unlike British authors who typically gave the 
Latin names for animals, Indians gave the local names of animals and described different species, typically by describing the different colors these animals appeared in. Many Indian hunters such as Sinha and Butt enjoyed natural history and viewing nature.

While Sinha shows a sense of restraint, other maharajahs flaunted their power over game in lavish private shoots, while emphasizing their good sportsmanship and character - the most important Victorian and Edwardian trait. From the record of hunting cards, which are located in the India Office and contain a list of sportsmen involved at specifc hunting events, we can ascertain that in the $20^{\text {th }}$ century there were more and more instances of the British hunting with Indians. For example, Brigadier Rahmat ullah Khan, Kartarsingji and Sirdar Attar Singh accompanied Colonels and Captains on a game bird shoot that included mallards, teal, and ponchards on the $19^{\text {th }}$ of November, 1933. Brigadier Rahmat ullah Khan also hunted with some Colonel Bailey and W. Nedore on March 31, 1933 suggesting that these were not simply one-time invites where Indians were given a chance to shoot with the British. Similarly, another hunt was most likely hosted by Maharajas and held on the $5^{\text {th }}$ of October in 1933 and had both the Maharajas of Bhopal and Kashmir along with Sirdar A. R. Effendi, Wazir Tez Alam, and Kanwar Bhim Sen shooting game birds with Colonel Bailey and Colenol Coloin. ${ }^{303}$ Deference was also bestowed to maharajas who consistently shot the greater amount of game birds and predominately appeared on the tops of game cards (hunting cards). At the Hokarsar Duck Shoot that was held on October 13, 1932, the Maharaja shot a total of 191 birds consisting of teal, mallards, pochards, gadwells, pintails, and wigeons in

${ }^{303}$ Hunting Cards and Licenses. British Library. Mss Eur F-157/807 
comparison to Col. Bailey and Col Colvin who shot 134 and 57 respectively even though the Maharaja stopped shooting ducks after lunch.

The duck shoot that occurred December 15, 1928 included 50 people with a total of 1, 359 ducks shot. There were 25 Indian men and 24 British men and two British women. While it was a common misconception among British sportsmen that Indian men were not good shooters because of a lack of technical skills with guns, the aforementioned duck shoot and other game cards disprove the validity of that statement. Indian hunters had moderately high bags of ducks that were on par with most British sportsmen. Maharajahs helped create the edifice that bound both British and Indian elite hunters together.

By the $20^{\text {th }}$ century, the maharajas laid the framework for the regal sport of hunting. Rajarshi Shahu Chhatrapati, the Maharaja of Kolhapur was instrumental in constructing the hunt as a regal sport. Staged regal hunts meant that wild animals needed to be procured. Therefore, the Maharaja of Kohlapur wrote to Krsnaraja Wadiyar, the Maharaja of Mysore, in 1913 to request elephants from the Forests of Mysore for his park. ${ }^{304}$ The maharaja of Kohlapur would also send the maharaja of Indore two shikaris as a gift. ${ }^{305}$ The generosity of the maharajas could be seen in their invitation lists. The Maharaja would invite various dignitaries to his park for hunting. Guests like L.J.

\footnotetext{
304 Letter. Shahu Chhatrapati to Krsnaraja Wadiyar. 10 ${ }^{\text {th }}$ Dec. 1913. Papers of Shahu Chhatrapati, Maharaja of Kohlapur Vol. VI, No. 296, (Kohlapur: Shivaji University Press, 1983), 378.

${ }^{305}$ Letter. Shahu Chhatrapati to Maharaja Saheb (Indore). 19 th Sep. 1916. Papers of Shahu Chhatrapati, Maharaja of Kohlapur, Vol. VII, No. 148, 189.
} 
Mountford, the Commissioner of the Southern Division of Belgaum, Lord Wilmingdon, and Count Hoyen of Austria came to Kohlapur expressly for the purpose of pig-sticking and cheetah hunting.

By the late 1940s, even nawabs were required to apply for licenses in order to hunt. In 1946, the Nawab of Banganapalli, Nawab Saiyid Fazl-i-Ali requested permission to shoot tigers in Kurnool District in the Nalamalai forest from the Resident in Mysore, Bangalore, Lieutenant -Colonel Gaisford. ${ }^{306}$ He received a letter that stated that he needed to apply for a license from the Government of Madras. In his follow-up letter to Colonel Gaisford on March 8, 1946, he wrote that he previously applied for licenses at the District Forest Officer's office in Kurnool. He was also put under surveillance during his shikar trip. The Nawab of Banganapalli had a background check done prior to receiving his hunting license because the government was afraid that he was working for the independence movement under the pretense of applying for a hunting license.

The Chief Police Officer did his research and stated that the Nawab did not meet Mr. H. Fida Hussain of Nandyal, an ex-political agitator or other ryots in the locality. So, he requested Colonel Gaisford for Rs. 500 from his account on March 25, 1946 to pay for the expenses he incurred to kill one tiger. This request was duly granted on March 29 , 1946. It shows that shikar was a very expensive affair by the $20^{\text {th }}$ century and that Nawabs were reliant on British residents to supplement the maharaja's own money. Many of the male relatives of the Nawabs were also big game shooters. For example, the

\footnotetext{
306 The Nawab's Request for Permission to go for a Tiger Shoot in the Kurnool District. No. CBS. 17-46. Mysore Residency. Bangalore. British Library. IOR/R/2/Box56/588 1946.
} 
Nawab of Banganapalli's uncle, cousins and brother were big game license holders. Even the Indian elite hunted within the framework of the government's laws and regulations on hunting.

\section{Educated Indians}

Many Indians wrote memoirs of their hunting experiences. All of the records of their hunting adventures come from the $20^{\text {th }}$ century, mainly because the population that was literate was very small in the $19^{\text {th }}$ century and because villagers did not write for posterity purposes. These memoirs often included advice about techniques on how to hunt, where animals were geographically concentrated in the subcontinent, and also a good deal of autobiographical information about the hunters themselves.

Indian hunters agreed that animals were God's creation (shrishti aramba) and should be protected. However, hunters had differing views on the Buddhist and Hindu principle of nonviolence. In the Bhagavad Gita, the question is posed to Arjuna "how can a person who knows that the soul is indestructible, unborn, eternal and immutable, kill anyone or cause anyone to kill?" 307 Killing is certainly not justified, but violence is enacted for supreme justice. This violence then has a utility. The greatest utility here is supreme justice for the dead cow. Sinha noted that the majority of villagers supported his endeavors of killing the rogue tiger that distressed local farmers. In fact, Sinha writes that a man from the village came to "inform us that one tiger has taken a cow from a group of

\footnotetext{
307 Swami A. C. Bhaktivedanta Prabhupada, Bhagavad Gita (Bombay: Bhaktivedanta Book Trust, 1983), 101.
} 
cows that were eating grass in the field." ${ }^{308}$ Therefore, Sinha and his father along with several other hunters immediately went to the forest to find the tiger and deliver justice for the man and his cow as well as to protect other cows from future danger. While Sinha certainly appreciated the lives of all animals, there was always a contradictory impulse to protect living creatures even at the expense of killing another animal, especially if that animal caused harm to humans or cows. Fathers were also quite proud of their sons after they got a bag. T.M. Ettan hunted in Kodamangalam, Kerala. T.M. Ettan's father said "he was very proud of his son"309 who shot a large deer. The brave or "nayatuka" behavior of the hunter was very much cherished among Malabari society. Ettan followed his father's foodsteps as his father was a great hunter as well. Ettan's son would become a hunter too and brought his father lots of bull meat which he enjoyed to eat.

Ranbir Sodhi Diwana was an Indian hunter who wrote a book called

Camparanya, mainly about hunting in Champaran in Bihar. He does not give autobiographical information about himself, however we know he hunted during colonial rule. Sodhi also discusses what he calls a topi or hub of small trees where animals come to drink water as a place to hunt game. Also, Sodhi stresses the principle of mantragan as he states a hunter should not kill a baby cub because the mother will become crazy and kill the hunter. Sodhi restrained himself from killing two baby cubs because he saw them and their mother as a royal family of rajas. Sodhi recalled his own mother and perhaps that is what led him to restrain himself.

\footnotetext{
${ }^{308}$ Ibid, 120.

309 T.M. Ettan, Oru sikkariy ute Smarayankal (Kottayam: Sahityapravarttaka Sahakaran asangham, 1971), 13.
} 
Hunting was a time when communal categories broke down. In Madhya Pradesh, Hindus and Muslims hunted together. Jamshed Butt, an Indian Muslim, states that Hindu Gond hunters often accompanied him on his hunts. Butt writes that all shikaris, ancestral hunters and learned hunters, should be able to give their life for another if the situation demanded it. By doing so, the bond between shikaris is as strong as a bond between brothers for in the jungle one must be able to give up their life for another or put oneself at risk to save another. By suggesting this principle, Butt clearly saw both tribal hunters and learned hunters such as himself on equal footing. Hunting was, in fact, often a family endeavor that emphasized male bonding. Both Pir Ali Mohammed Rashdi and Sri Bhupendra Chandra Sinha describe how their fathers accompanied them on the hunt. Butt's father was a forest contractor, but was not interested in hunting.

In addition to bonds developed among Indian tribal hunters, middle-class Indians also developed strong bonds with British hunters. In his book, Sodhi recalls how John Sahib referred to him as a younger brother. ${ }^{310}$ During their hunting trips, Ranbir would accompany John Sahib and another British planter in a Jeep to go hunt cheetal or deer in 1938. During these rides, friendships were formed and information exchanged. For example, John Sahib told Ranbir not to shoot a hyena because this animal cleared the jungle of bones.

Hunting was not just about shooting game, it was also about compiling new information about animals. Sodhi wrote about the footprints of animals and how to track

\footnotetext{
${ }^{310}$ Ranavira Sondhi, Camparanya (Mujapharaphura: Sandhya Prakasana, 1967), 13.
} 
them. Ranbir Sodhi writes that typically vegetarian animals are killed by non-vegetarian animals and the hunter typically hunts non-vegetarian animals. However, he was surprised when a tigress was playing with a baby goat when he thought it would kill the latter. For him, this scene was very touching and it reminded him of his mother. The act of hunting itself surprisingly drew him to familiar episodes and representations of the home.

Another hunter was Bachoo Narain Singh. He was a government employee posted in Hazaribagh. He also worked for the maharajas at the border near Nepal to get rid of game during his free time, when animals or people were injured by tigers. The maharaja would provide him a letter that served as a permit for him to hunt in the jungles. Singh hunted with other men who he terms "uske admi" or his men. They were probably tribals, however that is not clear. For one of his shikar trips, he was provided with coolies from Maharaja Mahadeo whose lands included the Tikri jungle near Ramghar. Typically, shikar commenced with hanke or the driving of game to a location where they were visible. He traveled to locations where tigers were spotted in a motor car.

Singh was ordered to shoot tigers when and if they attacked animals or people. For example, in the village of Basari next to Fatehpur, he was ordered to shoot a tiger which had killed a water buffalo. Singh's writings indicate he was a skilled hunter: he could tell from the footprints of a tiger whether it was a male or female and states he had killed two tigers before a year ago in that location. In 1946, he had hunted several tigers.

On one occasion, when Singh accompanied the maharaja who hunted in a car, a foot soldier came to tell him that a female tiger had been spotted. The king 
told the hunters not to shoot it until they decided whether or not the tigress was a maneater. The men who were helper hunters were all very upset because they would have naturally received respect and recognition. Maharaja Mahadeo used a 476 Denali rifle, which was custom made, but at the time was being cleaned. Using the 476 rifle, the king killed 250 of the 400 tigers. The maharaja was a good marksman and a great hunter. After the aforementioned tiger was found to have killed a person, shikar commenced and he used a 400 Denali rifle and missed the first shot. Singh, in a manner of deference, explained that when one man is familiar with one gun, he cannot be that easily accustomed to use another gun.

Like British authors, Singh noted the biggest catch he had bagged. For Singh, it was a male tiger that was 10 feet and 2 inches. He even states his whiskers were 9 inches and that he was very fat. After killing a tiger, he was also very upset when the skin was ruined due to bugs. Like British authors he also gave tips to other fellow hunters although he does not address his tips specifically to them. He writes that the best time to hunt the tiger is the afternoon because after a night of a lot of eating the tiger gets tired. ${ }^{311}$ Singh had a strong attachment to his favorite gun. He wrote "If you lose trust in your gun/weapon it is useless for you." He received his custom made Denali from A.D. \& Co. in Calcutta. He discusses his love for the gun, as he writes that "soon I began to like this gun a lot, and after the hunting season I fell in love with this gun. ”'With this gun, he believed he could never miss game especially birds.

311 Bachoo Narain Singh, Narabakshi bagho ka sikara (Illahabada: Lokhabharati Prakasana, 1966), 12. 
Many Indian hunters emphasized the cleverness of tigers. The word chalak or clever was littered in several hunting books. Tigers, hunters reported, did not return to the same area where they killed an animal or person because they were aware that people would look for them there. Therefore, the hunter had to resort to his wits to outsmart the tiger. Tigers in the Sunderbans were extremely chalak because they were man-eaters. The famous Bengali writer Biswanath Bose writes how the soil in the Sunderbans is salty with human blood, yet people still call this jungle the beautiful forest.

Hunting offered its participants an excellent sense of adventure and made men into heroes. Jamshed Butt, who was born in Punjab in present day Pakistan, wrote that he was "so keen on shikar that [he] was fully prepared to walk where angels feared to tread." ${ }^{312}$ Few hunters dared to hunt in dangerous locales such as the Madhya Pradesh jungles where dangerous beasts lurked. As an expert hunter, he displayed courage, strength, fortitude and many other manly traits. In addition to his rugged qualities, he also provided a paternalistic service to the villagers who suffered from attacks by wild game. Other hunters note in the foreword to Butt's book how "the men who have suffered serious losses due to the depredations of the tiger or the panther, [could rest assured that] Jamshed will protect them." ${ }^{313}$ Villagers were dependent on the selflessness of such men as Jamshed Butt. Butt was commonly called Khan Saheb as a title of respect as he had placed himself in danger to help downtrodden villagers numerous times. Butt took on the imperial role of protection that many British sportsman fulfilled during the

\footnotetext{
312 Jamshed Butt, Shikar (London: Robert Hale, 1968), 105.

${ }^{313}$ Butt, Shikar (London: Robert Hale 1968), 10.
} 
$19^{\text {th }}$ century. Therefore, the British were clearly not the only ones who protected Indians from dangerous wild animals.

Butt's book is styled as an in-depth guide to other fellow hunters and is filled with tales of his hunting experiences as well as tips on hunting. Jamshed Butt made a career out of shikar. He became a shikar organizer for Allwyn Cooper Ltd. in Nagpur during the colonial period. This firm was responsible for organizing big game trips. He also created his own firm called Tigers A Trails which provided clothing for big game hunters and provided expeditions for foreign sportsmen. Jamshed Butt typically accompanied American and British hunters into the jungles to help them find tigers. This gave firsttime hunters a great sense of adventure and happiness.

British hunters often remarked that Indian hunters did not have any sense of morality. Yet, Indian hunters had strong moral sense of what was forbidden and what was not. Jamshed Butt, for instance, writes that "Should the tigress appear first, alone, observe whether it is in milk, and if so do not shoot, you would be committing a crime." ${ }^{\prime 314}$ Tigresses were common targets during the $19^{\text {th }}$ century because they were seen as man-eaters. By the $20^{\text {th }}$ century, it was clear at least for Indians that tigresses who had to feed and take care of small cubs were off limits for the shikar experience. Similarly, Butt goes on to write that "a real shikari would never try to shoot a female animal, young ones or the very weak, nor leave a wounded animal in its agony." 315 Shikaris should take on the burden of finding suitable game that helps display

\footnotetext{
${ }^{314}$ Ibid, 67.

${ }^{315}$ Ibid, 22.
} 
the manliness of the hunter. He should also be a gentlemanly hunter who followed prescribed rules of etiquette.

British hunters commonly remarked that Indian hunters were "poachers" and that their rampant, indiscriminate shooting did not sustain the wild game population in an effective manner. Yet the sources suggest that Indian hunters did have a strong sense of the decline of game. M. M. Ismail, a Muslim Lieutenant Colonel of the Gurkha Rifles writes that "Only 15 or 20 years before the same jungles were teeming with game" when describing his visit to the jungles of Gorakpur near the Nepal border following independence. ${ }^{316}$ Ismail was writing in 1964 so he was referring to the time period of 1944-1949 when the jungles were full of game.

Hunting safaris were a time to indulge in grandiose recreation. Pir Ali, who also served as an advisor in the Pakistani government, describes a grand hunt that took place in Sindh in the 1930s. There were beaters, bearers, masseurs, physicians and a host of other individuals who helped with the hunt. Poets also wrote poems about the hunting experience in typical Mughal style. While the Sindhi elites hunted at these events, at other times, as Rashdi notes they could not carry a gun when entertaining a British official. The British official presumably had to display his masculinity in the midst of Indians watching and cheering on the shooter. The unequal display of power over the Indians was as apparent in the hunting arena as elsewhere.

Hunting did sometimes cause conflict between Muslims and Hindus. However, such conflicts were usually minor incidents. On one occasion, Pir Ali Mohammed Rashdi

${ }^{316}$ Col.-Lieut. M.M. Ismail, Call of the Tiger (London: Faber \& Faber, 1964), 15. 
shot three bucks and decided to distribute the meat to elite government officials. It so happened that Rashdi distributed it to a Brahmin household. The wife of the government official shouted out she was a pure Brahmin and could not believe that this blood stained her home and she proclaimed the house uninhabitable after the buck meat had entered it. ${ }^{317}$ The woman's reaction was quite hysterical as it was an unexpected event that happened to breach her customs. Nevertheless, Rashdi had only good intentions in mind when distributing game meat to government officials.

In Nehdimangalam, Kerala, Ettan hunted bull and described the various methods that he used to capture the game. He camped in an "allah" which was a hole in a rock which was about 15 feet in length by 5 feet wide. This allah was positioned near saltwater called ore where bulls would come to drink. During another hunting trip Ettan and friends camped at the site in a cave where sages lived so that they could build a fire and wait for the bull.

Another method that Ettan discusses in his book was called the villachanayat where a group of hunters would stand at specific locations where animals would be likely to cross when moving outside the forest into another forest. This was a good way to kill animals in the morning or afternoon instead of waiting overnight in a cave. Even though Indian hunting did not seem to have any etiquette to it, there were still unwritten rules to hunting. The person who shot the animal first got the meat of the insides (presumably the fattiest part) and the second person would get the neck portion. Other hunters would

\footnotetext{
317 Pir Ali Mohammed Rashdi, Sindh: Ways and Days: Shikar and other Memories (NY: Oxford University Press, 2003), 118.
} 
move down the body of the animal and receive small parts. Other times, Ettan would sell the wild bull (podhe kathwud) for 500 rupees.

The third method that Ettan hunted was to construct an oli or treehouse (called machan in Hindi) on which to sit and wait for animals to appear. This same method was used among both British and Indian hunters. Unlike British hunters and North Indian hunters who came prepared with biscuits and tea to eat and drink, Ettan and his hunter buddies relied on the forest for sustenance. Ettan wrote that he ate squirrels, tortoise and monkeys. If they were close to water then he would catch crocodiles and eat them.

While most Indian hunters were not poachers, there were a few who hunted for business, while hunting for food as well. Ettan shot elephants for their tusks and got Rs. 1000 to Rs. 1500 for each tusk. He wrote that he did not want to take the tusk, but he did because his friend insisted on it. Rs. 1000 was quite a lot of money during the colonial days and was a strong incentive to continue to shooting elephants. The shooting of elephants was illegal. He wrote that the person who bought the tusk came to his home to collect it. Tiger body parts were also sold when they were shot. Ettan writes that there were two small pieces of fur that are underneath a baby tiger's neck. This was sold to a British man for Rs. 10 which was used as a decorative piece on a British woman's dress. The tiger skin was sold for Rs. 50 and the nails of the tiger sold for Rs. 2.5. Ettan used deception when poaching to ensure that he and his hunting buddies would not get caught. Ettan's friend pretended to be bitten by a snake in order to quickly pass through the forest checkpoints to ensure that the tusks were safely brought to his 
home or buried the tusks into the ground at a particular location that the buyer was aware of. This method kept the forest guards unaware of the stolen tusks. This would vindicate the stereotype of Indians as poachers.

Ettan also used various methods of hunting that the British would have looked down upon. For example, he dug a hole into the ground and covered it with leaves so that an elephant would get trapped into the hole and eventually die. This allowed for Ettan to quickly take the tusks. While he did use methods that the British did not approve of, he also used similar methods as British hunters. Ettan paid attention to the direction the wind was moving to know which direction the animal would be approaching him. Ettan used a thread to checking to see which direction it moved in to determine the wind patterns.

At one point he received government permission to kill an elephant because it killed humans. The government allowed him to receive one tusk and the other tusk was given to the government. He therefore acquired a showpiece as he did not sell this legal tusk, but kept it for display in his home. It is quite surprising that Ettan was given permission to shoot an elephant considering that he once was summoned to the court for poaching elephant tusks. However, there were 10 other people that were also brought to trial for the incident. Only the first two hunters were sentenced to jail for six months and had to pay a Rs. 60 fine. The rest of the eight people were sent home without any punishment. Ettan was involved in the poaching incident because it was his gun that was used by one of his friends, however, he was not present during the actual shooting of the elephant.

The collaboration between the British and Indian hunters is quite solid as Ettan 
describes how he borrowed a gun from a British man, for which he had no license, and describes illegal shootings he pursued. He would later go on to buy a gun from Bombay with which he shot 200 deer, 10 male elephants, and 50 bulls. Excess was possible with a gun made in Europe.

\section{Tribal Hunters \& other subalterns}

While there are no written accounts of hunting experiences by tribal hunters, there are several British and Indian accounts that include descriptions of tribal hunters. Most accounts include information about interactions with tribal hunters. As with any other subaltern history, these accounts must be approached with a critical eye since they are most often written by individuals who have a perceived bias against low-caste tribal hunters. British hunters referred to Indian tribal hunters as people who were close to being savages, while Indian hunters similarly had their own biases towards those who were different from them. Richard F. Burton notes that the tribals were "half-naked wretches." 318 This phrase seems to be reminiscent of the European distaste for those they considered to be uncivilized persons. Bishop Heber writes that the Puharrees in Bihar are "dirty in their person in comparison with Hindoos" and the "men dislike hard work and prefer hunting." ${ }^{319}$ Hard work for the British meant agriculture or commerce or another industrious pursuit. The British looked down on hunting for subsistence. Hunting was

\footnotetext{
318 Richard F Burton, Goa and the blue mountains, or, Six months of leave (Berkeley: University of California Press, 1992), 323.

319 Reginald Heber, Bishop Heber in Northern India; selections from Heber's journal, ed. M.A. Laird (London: Cambridge University Press, 1971), 103.
} 
supposed to be a leisure sport, not an occupation. The lack of civilized conduct generally was equated with one's dirtiness.

Tribal hunters were organized into different levels of hunters. Hoji shikaris were generally regarded as head shikaris. We do not have much information about tribal shikaris because there is a lack of documents written by tribal shikaris. Everything we know about them is distilled through the lens of the European or the elite Indian. All sources are from the outside of tribal society, yet it is possible to discern the tribal people's views through the methods of subaltern studies. The task of subaltern studies is to give a voice to the underprivileged in the historical record and to recreate a fragmentary narrative of their experiences. This is just the task that is accomplished in Ranajit Guha's article "Chandra's Death" which discusses a rural abortion which leads to the death of a young woman. While there is no evidence of Chandra's personal writings, Guha carefully readsand critically evaluates the existing sources and elaborates the historical context to explain her feelings and emotions. Guha has reconstructed the historical context by piecing together fragments of the court deposition and the ekrars or guilt acknowledgements. He also presents a history of the low class Bagdis who were primarily farmers and discusses the crisis that ensued after the pregnancy that resulted in the entire family contributing to help pay for the abortion because they were threatened by a child which would be born from an unapproved relationship. ${ }^{320}$

In the same way that Guha unearths and recreates for the reader part of the life,

\footnotetext{
${ }^{320}$ Ranajit Guha, “Chandra's Death,” In A Subaltern Studies Reader, 1986-1995, ed. Ranajit Guha (Minneapolis: University of Minnesota Press, 1997), 45.
} 
traditions, and norms of rural society, similarly, it is possible to discern in several sources the attitudes and experiences of tribal hunters. In a similar manner, descriptions of tribal hunters give the reader a sense of what tribal hunters hunted and how they managed to do so in an anthropological manner. The conflicts between Indian hunters and tribal hunters as well as British hunters and tribal hunters are also expanded upon in this section to show the social disagreements and variances that occurred between the two groups.

The methods by which Indian tribal hunters hunted have also been recorded. Bishop Heber states that the Puharrees shot game by using poisoned arrows. The poison was obtained in the form of a gum, which was purchased from a mountainous people called the Garrows (Garos). ${ }^{321}$ Tribals did not believe in the Hindu, Buddhist and Jain concept of ahimsa or not harming another living being or animal. Instead, Heber describes how the tribals would take revenge upon an animal if someone was killed by another animal. The concept of ahimsa or non-violence as Gandhi defined it, especially in regards to man-eating tigers that killed people was very much an ideal, as revenge was almost always exacted even by Hindu villagers.

It is difficult to lump all tribal peoples into a single category because Bhils are not the same as Gonds. Some tribal peoples such as the Shendoos, who Edward Balfour described in his Cyclopedia of India and of Eastern and Southern Asia were originally from Burma in North East India. These were peoples who resided in remote regions and lived among themselves in clans. They were also in possession of muskets, that were not

${ }^{321}$ Ibid, 107. 
European made. ${ }^{322}$ Captain Thomas Herbert Lewis, a Deputy Commissioner of the Eastern Hill tracts, wrote that the Shendoos were quite intelligent and instead of using bows and arrows, they manufactured gunpowder from sulfur, which they obtained from Burma, and saltpeter, which they got from the ground and mixed with urine. ${ }^{323}$

Indians therefore did not have to rely on Europeans to kill game. Other tribes such as the Lhoosai also of Northeastern India carried swords in addition to bows and arrows. In this manner, the tribal hunters were harvesting game in a sustainable manner, whether they knew it or not, because European manufactured muskets and guns were far more dangerous to game than were the swords, bows and arrows and native manufactured saltpeter and sulphur concoctions used in Indian made guns. Sinha states that the Garo tribal peoples used guns while hunting. ${ }^{324}$

The hanging of trophies from a successful "bag" was also not an exclusive Western practice. Captain Lewis recalled how Kumis, another tribal people who primarily resided in the Chittagong area of Bengal, displayed "troph[ies] of arms and skins, including buffalo horns and mixed with weapons, such as shields, powder horns, spears \& c." ${ }^{\prime 25}$ The trophies of the hunt were all put up for display in one of Kumi's bamboo houses. It displayed the hunter's masculine prowess and his ability to conquer so many different types of animals, represented by the different types of skins that were

\footnotetext{
${ }^{322}$ Edward Balfour, ed., Cyclopedia of India and of Eastern and Southern Asia, vol 5 (Madras: Lawrence and Adelphi Presses, 1873), 275.

${ }^{323}$ Capt. Thomas Herbert Lewis, Wild Races of South-eastern India (London: W.H. Allen \& Co., 1870), 283.

${ }^{324}$ Sinha, Bana jangala o sikara katha, 115.

${ }^{325}$ Lewis, Wild Races of South-eastern India, 224.
} 
hanging in the home. Unlike the British, some tribals went a little further with the remains of game and made amulets of whiskers or claws of a particularly ferocious tiger that was said to protect the hunter and safely deliver the hunter to his home every night. $^{326}$

Famed Victorian explorer Richard F. Burton noted that the "hill people when not employed in spearing and netting game on their own account, will generally act as lookers-out and beaters. ${ }^{\prime 327}$ Gonds, Bhils and other tribal men often served as beaters for both British and Indian sportsmen. Beaters often performed dual tasks of spotting and tracking game and also beating back the dense foliage of the forests. Like other British men and women, Burton seemed to suggest that that hill people (another euphemism for tribals) engaged in unnecessary poaching using unconventional, unsportsmanlike methods such as spearing and netting game.

F. E. Penny writing about shikaris in the Nilgiri Hills who were primarily of the Kurumba tribe states that they are a "strange race" who have a "firm belief in magic and witchcraft." ${ }^{328}$ The superstitious nature of the tribals was almost always a point that was stressed and highlighted by the British writers about the aforementioned, perhaps as a way to differentiate themselves from Indian hunters. Similar to Rudyard Kipling's Jungle Book, Penny describes the Kurumba as a paradise-like forest similar to the forest that Mowgli and Baloo the Bear lived happily in unison in. The Kurumba, Penny writes was

\footnotetext{
${ }^{326}$ F. E. Penny, Southern India (London: A. \& C. Black, 1914), 202.

${ }^{327}$ Burton, Goa and the blue mountains, 322.

${ }^{328}$ Penny, Southern India, 199.
} 
"born like the leopard and the monkey in the forest, he knows every track as the lost man knows his own garden." ${ }^{329}$ The British writer equates the Kurumba man as being on par with an animal as he was very close to nature in a simplistic, yet hardy manner. According to Kurumba legends, every man was also said to have his own brother "animal" in the forest, who presumably did not attack the man, but had something in common with that man on a deeper level. Interestingly though, the Kurumba were very much in demand for only they had the power in that region to successfully kill wild game that may have been bothering a villager's crops. Other tribals were very much in demand for British and Indian hunters who longed to have a skilled shikari help track and locate game for them. Hunters were not just in demand for their hunting skills. They learned to adapt to the needs of the British government. For example, the Kurumba sold wood they gathered from the forest to the Government Forest Department in the Nilgiri Hills district. ${ }^{330}$

Tribals formed close bonds with both the British and the Indians. M.M. Kaye writes in Golden Afternoon, her autobiography, how she received a present of a baby monkey from a local shikari. When someone gives another person a gift, this gesture usually makes the receiver happy and appreciative of the thought that someone else put into the gift. The baby monkey became Mary Margaret Kaye's pet and she enjoyed its presence. Therefore, even though there was a language barrier that prevented her from truly expressing her gratitude, she was quite content with the new companion that she

${ }^{329}$ Ibid, 199.

${ }^{330}$ Ibid, 203. 
received.

While shikaris were praised for their ability to track game, they were not always right. As many British hunting books have highlighted, there were bad shikaris and good, expert shikaris. Shikaris were also bound by luck. While several sportsmen described hunting as an art, it was also a game of chance, and hunters often had to act on impulse. A shikari who is left unnamed said to his sahib "Maro! Sahib-Maro!" translating to "Kill! Master Kill" after spotting what he perceived to be a tigress. Upon shooting, the British sportsman found out that he killed a tiger cub. Mary Margaret Kaye writes this was "a discovery that ruined his day, for one did not shoot tiger cubs: it was one of the things that was 'not done' and I have seldom seen him more upset." 331 We seldom find the true emotional experiences of British men, but they are present in women's accounts of the hunting events. While she does not expand further on the incident, the shikari's wrong impulse must have had an effect on the sahib-shikari relationship, which would have led to the erosion of relations between the two.

Tribals could also cause danger to hunters who entered into their territories. For example, Bipin Babu discusses how tribals threw spears at him when he entered their forests. Tribals marked their territory and did not permit others to enter their forests to capture game which was reserved for their sustenance. Similarly Ettan was afraid of shooting elephants because tribals would hear as they believed they were the only ones that had a right to attack animals in their domain.

${ }^{331}$ M.M. Kaye, Golden Afternoon (New York: St. Martin’s Press, 1998), 338. 
Indian villagers were mostly dependent on tribals, educated Indian sportsmen, and British hunters to protect them from dangerous game. Many villagers would not willingly join shikar campaigns against tigers because they would have to sit or sleep perched in a machan or treehouse platform underneath trees, which made them uneasy. The tamarind trees, which grew in abundance throughout South India, were believed to be the "abode[s] of the devils." ${ }^{332}$ However, some villagers did take matters into their own hands. Dr. Clara Swain, a medical missionary from America, noted that Indians made jungle fires to scare away tigers from their huts. ${ }^{333}$ These fires were not permitted by the Forest Department, but nevertheless may have saved people from dangerous beasts. Lindsay Jordan wrote that the Sholigars, a tribal people, were generally responsible for the burning of jungles in the Biligiri-Rangan hills of Mysore. These tribal people were also excellent trackers who collected honey, jackfruit, yams, and deer horns left on the jungle grounds, all of which they sold to the Government. ${ }^{334}$ Other villagers bought guns to protect their crops from dangerous animals. Therefore, protection and profit was intertwined together in many jungle burning cases. The government of Madras also afforded villagers the opportunity to make some money if they killed snakes, however the author notes that in many parts of the Coromandal Coast cobras were worshipped and daily pujas or prayers consisted of feeding them..$^{335}$

\footnotetext{
${ }^{332}$ F. E Penny, On the Coromandel Coast (London: Smith, Elder \& Co, 1908), 66.

333 Dr. Clara Swain, A glimpse of India (New York: James Pott \& Co. 1909), 20.

${ }^{334}$ Camroux, Mabel (Jordan, Lindsay). “Jungle Notes by a Jungle Wallah's Wife. British Library. Mss Eur Photo Eur 170, p. 15.

${ }^{335}$ Penny, On the Coromandel Coast, 305.
} 
In some regions villagers were not able to hunt because of village laws. For example, in Sindh in present day Pakistan (although there is a considerable number of Sindhis who are Indian), village laws dictated that no one could kill game unless they were from the elite families who had the privilege to do so. ${ }^{336}$ Village laws were often codified by panchayats where village arbitrations and decisions were enacted.

\section{Conclusion}

This study of Indian hunting has challenged several misconceptions surrounding the lack of morality and etiquette of Indian hunters. Such misconceptions have their origins in the perceptions and attitudes of British authors in regards to the behavior and practices of typical Indian hunters. Indian hunters increasingly wrote accounts of their own hunting experiences, modeled after the writings of British sportsmen. From this chapter, it is also evident that British sportsmen followed several Mughal traditions of hunting. Indian hunters wrote to tell their own stories of hunting while also highlighting their masculine experiences. The Mughals, Indian maharajas, and educated Indian hunters wrote to publicize their great hunting feats and offer tips to readers on how to sharpen their hunting skills. Most Indian hunters were not poachers and had a clear sense of morality, ethics and etiquette when it came to hunting. Most of these hunters abided by the hunting laws and regulations, but the British nevertheless created ideologies of difference in order to legitimize the superiority of their hunting traditions. The Mughals hunted to excess in many cases just as the British accused them of doing, however there

\footnotetext{
${ }^{336}$ Rashdi, Sindh: Ways and Days: Shikar and other Memories, 15.
} 
were some rulers such as Shah Jahan who exemplified both restraint and excess over the course of his reign. Mughal kings, just as their British counterparts, classified animals and indulged in natural history. Some differences between the Mughals and the British were the methods employed for hunting as early Mughals often used bows and arrows or swords in lieu of guns. The attachment to guns is something that is less marked in Indian sources than in British sources. Educated Indians however had a strong attachment to their guns. While Indian princely hunters were also labeled and denigrated as Oriental despots, they also showed a strong sense of ethics such as that displayed by the Maharaja Dewar Junior and Sri Bhupendra Sinha's sense of shristi aramba and mantragan. As shown in other chapters, the maharajas were instrumental for arranging hunting shoots. Educated hunters developed a strong sense of masculinity and moral sense. Educated Indian hunters were clearly aware of the consequences of their actions. As the poet Valmiki states in the Ramayana "You will find no rest for Eternity, for you killed a bird in love and unsuspecting." ${ }^{337}$ The hunter is cursed for his actions by Valmiki. Yet the taking of life is acceptable as it is a warrior's duty states Krishna in the Bhagavad Gita. These two opposing opinions often plagued the modern Indian hunter. A few Indian hunters hunted solely for protection purposes just as certain late $20^{\text {th }}$ century Britons did. Jamshed Butt is one such example. Tribal hunters were subsistence hunters who had adopted modern conveniences such as guns and established bonds with Britons and educated Indians and they were mostly viewed as people who had no moral sense by outsiders. The reality remains that the Anglo-Indian hunting tradition followed by the

\footnotetext{
${ }^{337}$ William Buck, Ramayana (Delhi: Motilal Banarsidass, 2000), 7.
} 
British was also followed by the Indians in the $20^{\text {th }}$ century. 


\section{Chapter 6: British Women and their Hunting Experience in the Raj, 1830-1947}

European women have been largely ignored in the scholarly literature of hunting both in British Africa and colonial India. Scholars have focused on women's non-official roles and their activities in British India, but have ignored the subject of hunting. As Mary Procida points out in "Guns, Gender and Imperialism" women took on masculine roles in India as they handled guns to protect themselves and had no problem stepping up to the plate to order Indian servants and the Indian masses in the absence of their husbands. ${ }^{338}$ As Phillippa Levine states in Gender and Empire notions of femininity were constantly changing. ${ }^{339}$ While hunting has customarily been an activity that historians have associated with masculinity, women have engaged in hunting or were bystanders to hunting as a sport. This complicates the masculinity narrative because the masculine narrative emphasized the fact that hunting was solely a manly sport. Joseph Sramek's “ 'Face him like a Briton': Tiger Hunting, Imperialism and British Masculinity in Colonial India, 1800-1875" argues that tiger hunting helped British men display their masculine prowess and their place as imperial rulers over India's environment. ${ }^{340}$ Similarly, for women, my argument is that hunting molded British imperial identities and helped create a new type of woman who was feminine but with masculine traits and attitudes. Not all

\footnotetext{
${ }^{338}$ Mary Procida, Married to the Empire: Gender, Politics and Imperialism in India, 1883-1947 (Manchester: Manchester University Press, 2002), 150.

339 Phillippa Levine, ed. Gender and Empire. Oxford History of the British Empire Companion Series (Oxford: Oxford University Press, 2007), 2.

340 Joseph Sramek, “Face him like a Briton': Tiger Hunting, Imperialism, and British Masculinity” in Colonial India, 1800-1875.” Victorian Studies 48, 4 (Summer 2006): 665.
} 
women however, were willing to embrace their new role. Some were spectators who simply espoused feminine traits and did not take on what were considered masculine attitudes and traits.

\section{Literature Overview}

It is important to survey the literature on women in order to properly assess the place of female hunters and spectators in colonial India. Prior to the interest in feminist historiography, British historians viewed memsahibs or British women residing in India with particular disdain and unimportance. Percival Spear in The Nabobs, for example, viewed British females in India as people who helped make the divide between the British and their subjects larger. ${ }^{341}$ This was because of their open racism towards Indians and because their presence in India led British men to distance themselves from Indians by no longer keeping Indian concubines and mistresses. Indrani Sen's Woman and Empire notes that memsahibs did not speak Indian languages unlike female missionaries and therefore they helped create a larger divide between the British and the Indians. ${ }^{342}$ In essence, British females were viewed in the older imperial history as impediments to masculine Empire building. These views were reinforced by British imperial authors. George Orwell in Burmese Days discusses the typical memsahib as he describes Mrs. Lackersteen who cannot endure the heat and who imported a rickshaw, the only one in

\footnotetext{
${ }^{341}$ Percival Spear, The Nabobs: a study of the social life of the English in eighteenth century India (Oxford: Oxford University Press, 1998), 150.

342 Indrani Sen, Woman and Empire: Representations in the Writings of British India 1858-1900 (Hyderabad: Orient Longman, 2002), 11, 57.
} 
the district, specifically to battle the heat. ${ }^{343}$ Mrs. Lackersteen constantly complained about the laziness of servants. The only good quality she had, according to Orwell, was her devotion and dedication to her husband, for whom she endured the hot heat of the Burmese jungles.

Gender historians have challenged the myth of the memsahib as lazy and inactive. Mary Ann Lind in her Compassionate Memsahibs: Welfare Activities of British Women in India, 1900-1947 has shown how the fifteen women she studied were active in educational and medical work. ${ }^{344}$ Their philanthropic activities showed their dedication to bettering Indian society. In addition to challenging outdated misconceptions, more recent imperial historians have highlighted the importance of gender in the Empire. Angela Woollacott's Gender and Empire volume has shown how "central [the] role of gender in the imperial enterprise [was], both as one of the forces driving and shaping the empire, and as a set of ideologies produced at once in the colonies and the metropole that constituted shifting and pervasive imperial culture. ${ }^{" 345}$ Gender historians have also challenged Percival Spear's view that European women were responsible for eroding imperial relations. Helen Callaway's Gender, culture, and empire: European women in Nigeria showed how in the case of Nigerial women studied native languages, helped

\footnotetext{
343 George Orwell, Burmese Days; Keep the aspidistra flying; Coming up for air (NY: Alfred A. Knopf, 2011), 23.

344 Mary Ann Lind, Compassionate Memsahibs: Welfare Activities of British Women in India, 1900-1947 (New York: Greenwood Press, 1988), 30-35.

345 Angela Woolacott, Gender and Empire (NY: Pallgrave Macmillan, 2006), 1.
} 
facilitate medical projects, and spread education. ${ }^{346}$ Women were part of the project of development of Nigeria and they fulfilled the overall goal of imperial benevolence. They also helped justify and strengthen colonial rule by introducing various development projects in colonial Nigeria. Gender historians have also argued against the view that memsahibs were racist. Western Women and Imperialism edited by Nupur Chaudhuri and Margaret Stroebel emphasizes this point. ${ }^{347}$ These essays like the study on women in colonial Nigeria further challenge and discredit the view that all European women were racist.

One of the key issues that imperial gender historians have treated is the idea that activities which are associated with masculinity have been intertwined with women's activities in the imperial setting. Pat Barr in The Memsahibs: The Women of Victorian India has also shown how women accompanied their husbands as active partners in many masculine activities such as serving as doctors, missionaries, or becoming writers especially about key events like the Mutiny. ${ }^{348}$ Mary Procida's Married to the Empire shows how many British women in India took on masculine roles as British women handled guns, ordered servants, and took over unruly crowds when their husbands were absent. In a similar way, Stroebel's European Women and the Second British Empire

\footnotetext{
346 Helen Callaway, Gender, Culture and Empire: European Women in Colonial Nigeria (Urbana: University of Illinois Press, 1987), 211, 210, 124.

${ }^{347}$ Nupur Chaudhuri and Margaret Stroebel Eds, Western Women and Imperialism: Complicity and Resistance, (Bloomington: University of Indiana Press, 1992), 3.

348 Pat Barr, The Memsahibs: the women of Victorian India (London: Century, 1989), 35.
} 
shows how women were active imperialists. ${ }^{349}$ Nevertheless, while examining women's roles there is a dynamic complexity here as they were also subordinate to European men. In The white woman's other burden:Western women and South Asia during British Rule Kumari Jayawardena discusses how women such as Annie Besant were involved in antiimperialist activities and how the Loreto Irish Catholic nuns developed convent schools. ${ }^{350}$ Similarly, Brittania's Daughters by Joanna Trollope surveys women's experiences throughout the Empire but does not hone in on hunting. ${ }^{351}$ She does however mention Kate Martelli's Tigers I have shot, who details her hunting activities in Rewa.

As Antoinette Burton's Burdens of History: British Feminists, Indian Women, and Imperial Culture notes, British feminists believed they had a burden to uplift Indian women mainly because of the preconceived notion that they were oppressed. ${ }^{352}$ This obligation was extended to the hunting field - however it addressed not only Indian women, but Indian male shikaris and servants as well. British female hunters believed they had a duty to uplift Indian hunters and prevent them from poaching for the good of all animals. Indira Ghose in Memsahibs abroad: Writings by women travelers in $19^{\text {th }}$ century India wrote that one cannot define the typical British memsahib because they are

\footnotetext{
${ }^{349}$ Margaret Stroebel, European Women and the Second British Empire. (Bloomington, Ind.: University of Indiana Press, 1991), 50.

${ }^{350}$ Kumari Jayawardena, The white woman's other burden: Western women and South Asia during British Rule (New York: Routledge, 1995), 125.

351 Joanna Trollope, Brittania's Daughters: Women of the British Empire. (London: Hutchinson \& Co., 1983), 104.

352 Antoinette Burton, Burdens of History: British Feminists, Indian Women and Imperial Culture, 1868-1915 (Chapel Hill, University of North Carolina Press, 1994), 129.
} 
complex individuals. ${ }^{353}$ Ghose does mention that women came to India for big game sport mainly because their husbands were in India, but she does not fully delve into the issue of hunting and women. Her research focuses on travelers rather than women who resided in colonial India for a significant amount of time.

This chapter investigates women's memoirs to construct a narrative of their experiences, viewpoints and ideologies by delving into private papers. I focus in particular on two groups of women: spectators and hunters. I argue that hunting molded British imperial identities, altered the identities of women and helped create a new type of woman that combined masculine and feminine qualities. British women who were spectators to hunts developed strong ideologies against the murder of game, enjoyed the sceneries and beauties of the hunt, and developed bonds of friendship or marriage while attending hunting events. Female hunters developed strong prejudices against shikaris, Indian women and men. Despite being hunters, they still felt strong emotions of fairytale experiences and felt remorseful when animals were shot, yet they also enjoyed eating gourmet meals after shooting animals.

\section{Background of Hunting}

Women's sources tend to be late $19^{\text {th }}$ century or $20^{\text {th }}$ century, however there are a few sources from the mid- $19^{\text {th }}$ century among spectators to the sport of hunting. In Britain, hunting was acceptable for women in the late $19^{\text {th }}$ century and this is the same time that hunting becomes acceptable and encouraged for women in the Raj.

\footnotetext{
353 Indira Ghose, Memsahibs abroad: writings by women travelers in nineteenth century India (Bombay: Oxford University Press, 1998), 55.
} 
While subsistence hunting is primarily seen as a native indulgence, British parties who recreationally hunted also did so for the purposes of varying their diets from the usual fowl and mutton. Women took great delights in hunting for the purposes of changing what would be served on the table. Women were often invited to regal hunting events even if they were not participants because the spectacle and feasts were part of the overall imperial experience.

\section{Reasons women hunted}

Women often accompanied their husbands, brothers or fellow British compatriots to the aforementioned destinations for the purposes of witnessing hunting events or to participate in hunts themselves. It should be noted that whether man or woman, British hunters were almost always accompanied by elephants, native shikaris or hunters and servants. Bagh or tigers, gavial, wild boars, peacocks, nilgai or antelope, sambur or deer were hunted by women in India. There were some hunters who hunted solely for the purposes of keeping their district safe from man-eating tigers. They were, however, a small minority and they were almost never women.

Hunting was defined as a therapeutic sport in India. Lady Greville recounted that: "Ladies of all ages and figures ride [in India] and, no doubt, ride there, in so doing, preserve their health and their looks." 354 This idea that exercise helped battle the hot tropical sun was a common climatic belief during the $19^{\text {th }}$ century. Hunting most often took place in the morning because of the hot Indian sun that appeared in the afternoon.

\footnotetext{
${ }^{354}$ Lady Violet Greville, Ladies in the Field (New York: D. Appleton \& Co. 1894), 19.
} 
The tropical sun was believed by the British to turn a person's body into a degenerative state. In a similar way, the Europeans during the $19^{\text {th }}$ century viewed West Africa in general as a "white man's grave" and therefore many important figures in England, like Zachary Macauley, supported the idea that West Indians were more physically adapted to the harsh West African sun and terrain than Europeans, who were not as well-suited to the climate. In India, there was some belief that a European's physiology was affected by the sun. While some women did tend to stay indoors to remain fair or because the heat was unbearable, others joined in attending hunting events. Even though sport hunting could possibly put women in danger because of the threats associated with malaria, leeches and infection from falls, it remained popular with them because it was seen as a way to keep one healthy.

\section{Women as Spectators to the Hunt}

As noted above, this chapter focuses on two types of hunting that involved women: recreational sport hunting and regal hunts, with the former taking precedence over the latter because more women were involved in the former. Recreational hunting created a sense of excitement and adventure for women. That sense of excitement and adventure was always coupled with extended moments of silence and long periods of waiting. The sense of adventure that Joseph Sramek’s “'Face him like a Briton': Tiger Hunting, Imperialism and British Masculinity in Colonial India, 1800-1875," most often associates with masculinity, can also be seen in women's writings about hunting. However, hunting also required a lot of sitting quietly waiting for an animal. Women 
were often perched in trees in a tree chair along with men. Waiting in the trees was something which helped drive up the intensity of excitement for it helped build up the sense of anticipation and adventure when an animal did appear within shooting range. Therefore, we can assume this excitement and adrenaline rush was part a shared emotion that both British men and women possessed. The "chase," as women would call it, was a great sensation that drew women to participate in hunts or to be spectators. Fanny Eden, the sister of Lord Auckland, noted how the "half-hour's chase was just as grand to see. ${ }^{" 355}$ She was referring to a rhinoceros hunt. Emily Eden, Fanny Eden's sister goes on to mention that she was also part of a cheetah hunting event where cheetahs were let loose among a field of antelopes. She mentions that there were "two or three good chases this morning but no antelope killed, which was rather a blessing. ${ }^{.356}$ Her feminine side can be seen here as she hopes that no animal gets hurt. In many men's published hunting books, their masculinity triumphs when the animal is killed. In the majority of women's texts, however women are content even if the shoot is unsuccessful. Lady Beatrix Scott wrote the following of the tiger shoot in Goalpara: "It was not a successful shoot, but it is a very pleasant memory."${ }^{\prime 357}$ The pleasant memories involved in the hunting experience always surpassed the death of the animal and differentiated women's accounts from men's hunting memoirs. Most men were unhappy with a lack of a "bag" to bring home, while women were content with being able to imbibe the whole experience of the hunt.

\footnotetext{
${ }^{355}$ Fanny Eden, Tigers, durbars, and Kings :Fanny Eden's Indian Journals, 1837-1838 (London: Murray, 1988), 25.

${ }^{356}$ Emily Eden, Up the Country: letters written to her sister from the upper provinces of India (London: Curzon Press, 1978), 354.

357 Scott, Lady Beatrix Papers."Tiger Shoot at Goalpara.” Box 1-6: 97. Center of South Asian Studies. Cambridge University.
} 
Observing the hunting experience was often very amusing for women because it gave them something to do. Mrs. H. Barkely Smith noted while recalling her first tiger hunting experience how during Christmas holidays she found it very amusing. For women, simply watching the shooting was a nice amusement and change out of the ordinary. The hike through the forests was interesting as well.

A typical recreational hunting activity occurred in Goalpara. These recreational activities were generally organized to relieve the villagers from tigers who were eating their cattle. Lady Beatrix Scott along with her husband Sir Walter Scott, who was an Excise Commissioner in Assam, were invited by the District Commissioner of Goalpara for a tiger shooting event during the Christmas holidays. A "minor" raja also provided elephants for the event. Camps were provided for the guests. Two ten year old sons of the District Commissioner were also in attendance. Women who were not shooters typically sat on top of beating elephants where they were able to see the entire hunt. Women however were typically viewed as people who got in the way of shooting activities. Lady Scott recalled how "[t]he guns were furious because at the one moment they might have bagged the tiger they were afraid of hitting me." ${ }^{358}$ The guns refer to her husband Sir Walter Scott, whom she affectionately called Scottie and Mr. Laine, the District Commissioner. While she does not record any instances of men stating that they missed the tiger due to her presence, it is implicitly implied that she was "in the way." For women knew that their presence could mean an extra burden placed upon the shoulders

\footnotetext{
358 Scott, Lady Beatrix Papers."Tiger Shoot at Goalpara.” Box 1-6: 96. Center of South Asian Studies. Cambridge University.
} 
of their male companions because they had to protect women while simultaneously capture a "bag."

Indians were also responsible for all the potential pitfalls and dangers associated with the well-being of the Anglo-Indians - both men and women. Even for minor accidents, the Indian shikari could have his reputation forever tarnished and his ancestral occupation stripped away with a bad chit or document that explained the character of the native employed in the services of a European. Although it mostly seemed that hunting was a sport where Indians were on equal terrain with British residents, it was not always the case. Similarly, Indian shikaris also were quite wary of female hunters who were viewed as possible threats to their safety and livelihood. Mrs. Baillie mentioned how a shikari remarked "If the mem-sahib [lady] comes it will put us all in danger: we shall have to help her into a tree first, before we can climb, and if a bagh (tiger) comes at us then we shall have no chance [...] Laximan said, his sahib [master] had told him not to let me get into any danger, and I was in his charge and he would get all the blame if anything happened." 359 The added responsibility of ensuring that the memsahib was safe was an imperial and chivalrous right that women were entitled to.

This added protection allowed women to gain confidence in themselves and venture farther out in order to see all the action during hunting events. Even in dangerous tiger hunts, M.M. Kaye writes how “Mother yelled at me to get back for heaven's sake

359 Mrs. W. W. Baillie, Days and Nights of Shikar (London: J. Lane \& Co., 1921), 49. 
and not to take risks. But I couldn't see how there could possibly be any risk; not with a mob of beaters surging around the tree trunks." ${ }^{360}$ Mary Margaret Kaye was quite bold to try and get closer to the tiger so that she could see it. The beaters instilled great confidence in her and countless other women.

Lady Beatrix Scott found companions in other women during hunting expeditions just as males found companionships in their shikaris or in other British males who accompanied them. Hunting was a time when women could discuss their daily life, their children, their servants, their families, or their husbands. Anglo-Indian exclusivity usually meant that the status quo did not permit outward displays of friendship between Indians and British females. Nupur Chaudhuri's “Memsahibs and Motherhood in $19^{\text {th }}$ century Colonial India" emphasizes the concept of Anglo-Indian exclusivity. ${ }^{361}$ European women preferred to talk to other European women. Similarly, they preferred European midwives and were uneasy about Indian females serving in that capacity. This exclusiveness was present in hunting mainly because of the absence of Indian women in hunting. Therefore, it might not have been out of choice that they tended to form bonds of friendship with other British women, but because there were no Indian women whom they could form bonds with. British women did enjoy socializing with fellow British ladies during hunting events especially since it was an opportunity to meet them and have a meaningful conversation.

Hunting was also a time when women were able to indulge in mingling with men.

\footnotetext{
${ }^{360}$ Kaye, Golden Afternoon, 338.

${ }^{361}$ Nupur Chauduri, "Memsahibs and Motherhood in Nineteenth-Century Colonial India," Victorian Studies 31.4 (1988): 522.
} 
Eligible women could find hunting expeditions as places to meet men. Fanny Eden noted that handsome men could be found at hunting events. She wrote of the Raja of Nahun remarking that "if the rajah fancied an English ranee, I know somebody who would be very happy to listen to his proposals." ${ }^{362}$ While Fanny Eden does not delve into the matter further, the issue of attraction and sexuality is clearly present in this statement. Her fondness of the raja as well as her apparent attraction to him would have been a problem for Victorian standards, which emphasized the purity and aloofness of British women. In the $18^{\text {th }}$ century, relationships between British males and Indian females were common. As Durba Ghosh in Sex and the Family in Colonial India: the making of Empire has shown, such relationships gave British males access to indigenous knowledge and forged political alliances. ${ }^{363}$ In the $19^{\text {th }}$ century, as more British women came to live in India, attitudes towards such relationships in colonial society shifted from one of tolerance to disdain.

Ronald Hyam in Empire and Sexuality: The British Experience deals with the private question of sexuality, however he focuses on British males and their attractions towards native women mainly because of a lack of British women in the colonies. ${ }^{364}$ Like Ghosh, Hyam also emphasizes the fact that relationships with these women helped

\footnotetext{
362 Eden, Tigers, durbars, and Kings, 119.

363 Durba Ghosh, Sex and the Family in Colonial India: the making of empire (Cambridge: Cambridge University Press, 2006), 50.

364 Ronald Hyam, Empire and Sexuality: The British Experience (Manchester: Manchester University Press, 1990), 25.
} 
facilitate political alliances and gather knowledge about the respective native community. Even married women could not help but note the outstanding fineries that the maharajas displayed in their dress even if they were not personally attracted to them. Mrs. E. Barrett wrote of the diamond stud the maharaja of Jaora had on his ear and an embroidered sleeve full of gold and silver thread in a pattern of flowers and leaves. Mrs. H. Barkely Smith mentions that she met her husband, a British male, during a tiger shooting event. Hunting events were therefore an opportunity for both British men and British women to seek courtship, love, and marriage. It was only a dream for British women and Indian maharajas though. Indians were also in awe of British females because of their difference from the native population and this has been accounted in several memoirs by Fanny Eden and others. Hunting expeditions were also times when servants and the general public could stare at British women.

Gazing was part and parcel of the hunting event. Women who did not engage in hunting themselves, could instead indulge in the picturesque sceneries, especially when their companions hunted. Lady Ouvry noted that when her husband went out fishing, she went out bathing. She notes how it was such a delightful experience to bathe in a sari in the river. She notes that it was pleasant and different. Natural experiences such as these were all quite common.

The imperial gaze over the Indian landscape was a thoroughly British experience. Indians did not travel for the sole purposes of experiencing beautiful sceneries. The 
pleasure of listening to the sound of birds was not something that one heard in Calcutta, which made it another asset of the jungles that women entered for the purposes of hunting. Even the maharajas and elite Indians did not visit Kashmir solely for the purposes of experiencing the pretty landscapes. In addition, classification and ordering of items was part and parcel of the imperial experience. As Bernard Cohn states, Europeans tried to monopolize Indian knowledge to effectively subjugate the Indian population. ${ }^{365}$ This argument can be extended to the Indian environment as British men and women tried to record natural history and know the Indian environment better than the Indian did himself. The British then tried to control the channels and networks through which knowledge was circulated, and sought to define what was "scientific" knowledge. They relied heavily on local knowledge to accomplish and help define what was "scientific." For example, they could not have engaged in hunting in India without shikaris who knew the locations and secrets to a successful hunt. The imperialists indulged in the classification of items and women in particular liked to describe the types of flowers they saw and noted their similarities to English varieties. Several women such as Fanny Eden, the sister of Lord Auckland, also sketched these flowers as addendums to their work. In addition to flowers, fauna was classified and great advances in natural history were made. The British were aware that Indians were often sketchy on varieties of animals. Hunting was a way for British women to participate in other imperialistic activities such as

\footnotetext{
${ }^{365}$ Bernard Cohn, Colonialism and its Forms of knowledge (Princeton: Princeton University Press, 1996), 5.
} 
documenting the environment. Women also documented the types of people they met, their customs, as well providing descriptions of the types of animals they saw and their traits. While not hunting, women went to see such places as the Taj Mahal or other famous sites like the mountain Nanga Parbat.

While some women in India found killing of animals disgusting, others cherished the fact that they witnessed a shooting of a wild animal. Fanny Eden noted how she was "rather proud of having seen a tiger killed because except Mrs. Cockerell there is not another woman in India who has, I believe." ${ }^{366}$ This statement suggests it was rare for women to be involved in hunting events let alone a tiger hunt. These women were therefore not representative of the entire female community in British India. However, Fanny Eden is writing in the mid- $19^{\text {th }}$ century when women were rare in British India. By the $20^{\text {th }}$ century, Fanny Eden's statement would no longer hold as there were many more women in colonial India. In terms of women, she was most likely describing European women. She would forever go down in posterity among the Anglo-Indian community for having witnessed such a feat. Indian women, unless they were a maharani, never accompanied the tiger hunting spectacle. Therefore, there was a certain prestige that was associated with the feat of watching an animal die under the gun of a man or woman. Just as men believed it was a great prestige to have their foot placed in a tiger's mouth, women too believed watching a wild animal being shot down and killed was a great feat. This was certainly a feminist ideal where one woman represented the rest of the female population's achievements.

\footnotetext{
${ }^{366}$ Eden, Tigers, durbars, and Kings (London: Murray, 1988), 52.
} 
John Mackenzie in The Empire of Nature: Hunting, Conservation and British Imperialism notes that British residents were obsessed with participating in or witnessing hunts. ${ }^{367}$ Fanny Eden notes how she and Mrs. Cockerell accompanied her nephew William Osborne of the $16^{\text {th }}$ lancers who was the only one who had a gun to shoot a wild buffalo that was reported by an Indian servant at night. She notes that her nephew "set off for it like a madman, followed by the others like so many madmen." ${ }^{368}$ The term "madman" suggests she was critical of these hunters and the way they acted. As the above examples testify, the obsession with hunting was a British imperial phenomenon that included women as well. Some women cherished attending hunts, however there were some women who did not enjoy watching hunts.

Some women equated hunting with murder especially after they witnessed the shoot. This could be part of their ability to express their conscience more clearly than men or an illustration of their femininity. Fanny Eden wrote that after the wild hog "had five balls through it $[\ldots]$ I settled that I had no taste for the shooting part of the expedition...I thought that hog's was a shocking case of murder." Even though Fanny did not actually witness the event, she heard about how they trampled it to death and upon the party's insistence to look at it after it was dead, she stated "it seemed to be such a fine strong beast so exactly fitted to its own jungles - I do not see our right to take our love of destruction there. ${ }^{\prime 369}$ The moral conscience and a greater sense of right and wrong was

\footnotetext{
${ }^{367}$ MacKenzie, Empire of Nature, 168.

${ }^{368}$ Eden, Tigers, durbars, and Kings, 38.

${ }^{369}$ Eden, Tigers, durbars, and Kings, 21.
} 
most visible in Victorian women - it was a most prized feminine trait. This also further illustrates how Fanny Eden questioned the British presence in India and the British right to decimate Indian game. Moreover, Fanny noted how men went about murdering animals without remorse. She writes of her own nephew, William Osborne going "from one jeel [jheel] to another, murdering the innocent wild ducks." ${ }^{970}$ In most men's hunting books, they emphasize the fact that hunting is an art and is not the same thing as murder. Viewing hunts helped women form distinct opinions on hunting as a sport.

Watching the death of an animal was something which many women did not have the heart to do. Even though British women accompanied hunts and enjoyed the "chase" where wild animals sought to get away from the hunter's bullet, watching the actual shooting and its death was something that many women refrained from doing. It symbolized their emotional side and their feminine side. Fanny Eden noted how "I turned away my head when they shot it, because I have a natural distaste to see a large beast die." ${ }^{371}$ This distaste was a predominant feminine quality that most British women in India possessed.

Not all women enjoyed hunts even though they witnessed hunts due to their commitment to the $R a j$ and their imperial place in its structure. Emily Eden, the sister of Lord Auckland the Governor-General of India in 1838, wrote that "[w]e could not complain of want of sport, but it is rather a butchering business." 372 She wrote these lines

\footnotetext{
${ }^{370}$ Eden, Tigers, durbars, and Kings, 10.

${ }^{371}$ Eden, Tigers, durbars, and Kings, 35.

372 Eden, Up the Country, 356.
} 
after watching the sport of hawking where ducks were caught by hawks. She seems to suggest that hunting is murder.

Village amusements that included the spectacle of animals hunting each other were events where the maharajas entertained the British. Harriet Tytler recalls her attendance at one of these village hunts where a water buffalo and its calf were brought out in the middle of the village square with four tigers surrounding them. The calf was killed by the tiger and the water buffalo killed by the maharajah's men for all to feast upon. The next hunt/fight was between a tiger and bear. After experiencing the entire ordeal, Tytler wrote "We were so thankful to escape from all this amount of cruel bloodshed. No one would have dared to leave their seats in the King's presence, such breach of etiquette would have been unpardonable, there we had to remain till he arose... I have seen elephant and deer fights in other native states, but that is all very stupid and monotonous. ${ }^{\circ 373}$

Some women were afraid of the power of wild animals and did not care to witness hunts. Harriet Tytler noted that an owl who her husband had shot in her home had "fixed his eyes on the little one, who was quite well then...kept gazing at the baby."${ }^{.374}$ Her baby later died and she believed that the owl was responsible for its death because it cast an evil eye on her child. While British male hunters commonly noted how tribal Gond and Bhils believed in such superstitions about the evil powers of the spirits of such animals, some British females may have believed them as well and it highlights their feminine side

\footnotetext{
${ }^{373}$ Harriet Tytler, An Englishwoman in India: the memoirs of Harriet Tytler, 1828-1858 (Oxford: Oxford University Press, 1986), 67.

374 Tytler, An Englishwoman in India, 83.
} 
based on common presumptions of what characterizes feminine traits. British men often used the fact that tribals believed in such superstitions as a way to show how they were more masculine then the tribal hunters. They never really stated that British females were superstitious as well because it was seen to be an "Oriental" thing more than a Western supposition. However, it could also be that Mrs. Tytler was struggling with explaining the sudden death of her little baby and she was not a superstitious woman and this was a way to cope with the loss of losing her child.

Likewise, women made the connections between humans and wildlife. Indian men also made the same connection. They were aware that female elephants were mothers as well. Lady Beatrix Scott wrote how an elephant "ran to comfort the injured baby" referring to a ten year old boy. She continued by stating "[i]t was a touching sight" 375 and clearly emphasized the connections between domesticated elephants and humans.

Sometimes the death of an individual by a tiger or other ferocious beast led women to steer clear of hunts. Lady Curzon noted how watching the death of the Nizam's shikari "sickened me for wild animals." 376 However, earlier she noted how on tiger shooting in Nepal with the Maharajah that "[i]t was so sudden and thrilling that my eyes were falling out and my tongue tied." Lady Curzon was referring to the tiger that was trying to escape and her husband and Captain Baker-Karr firing upon the tiger. The tiger hunt was a great excitement which caused adrenaline to rush throughout her body. It was

\footnotetext{
375 Scott, Lady Beatrix Papers."Tiger Shoot at Goalpara.” Box 1-6: 97. Center of South Asian Studies. Cambridge University.

${ }^{376}$ Lady Mary Curzon, Lady Curzon's India: letters of a vicereine, ed. John Bradley (London: Weidenfeld \& Nicolson 1985), 142.
} 
such a thrill that her writing highlights the sense of adventure. She also notes how the camp was "a perfect fairyland." 377 The maharajah had organized sandwiches and a full dinner to follow the tiger shoot and this for Lady Curzon was a fairytale. However, this excitement and fairytale-like quality quickly died out a few years later when someone was mauled by a tiger and she witnessed the event.

Indian men responded to British women's stance against cruelty towards animals. Behramji Malabari, a Parsi or Zoroastrian originally from Iran, but whose ancestors settled in the Bombay Presidency, noted how British women were big hypocrites in regards to their views on hunting. He notes that "[t]hey are ready to cry out against cruelty to animals, and yet indulge in fashions involving barbarous cruelty, the plucking of birds and skinning of animals, after they have been destroyed for the purpose. The fashions of British women were derided for their ignorance at where their fashions came from." ${ }^{378}$ Women by nature are said to be more emotional and care for cruelty to animals from sudden death by shooting. However among many fashionable women double standards were upheld.

Women did understand that animals needed to be killed even if they did not agree with hunting as a sport. Many women could only fully understand an animal's death on a hunting expedition after facing a near death experience. Mrs. E. Barrett writes of a wild pig in poignant terms. She writes "There he lay in a welter of gore, 300 pounds of gallantry provoked to death for the pleasure of man. Speechless, tears on my face, I stared

\footnotetext{
${ }^{377} \mathrm{Ibid}, 51$.

378 Behramji Malabari, The Indian Eye on English Life or Rambles of a Pilgrim Reformer (Bombay: Apollo Printing Press, 1895) British Library1889-1895 10349.dd8
} 
at the dead boar whose victims so nearly we had been. I understood then why pig must be ridden. No other death is worthy such an adversary." ${ }^{379}$ If the pig did not die at the hands of the hunter, Mrs. Barrett would have died. This helped solidify the reasoning behind game deaths for women, who were quite uneasy about the unnecessary deaths of animals.

\section{Women Hunters}

While most British women in India were at best ambivalent about hunting and were usually spectators, a small group actively participated in hunting and emulated men in their attitudes and skills. Isabel Savory gave the reader, whether woman or man, tips on how to properly hunt while using the correct technique and etiquette. An experienced hunter, Savory stated that "[the spear] should be carried when riding diagonally across the body the shaft lying underneath the forearm so that it is ready to hand, less dangerous to one's friends when riding and to oneself when falling." ${ }^{380}$ She was referring to the spear when one is pigsticking. Offering advice to fellow hunters or other amateurs was a part and parcel of the community-like nature of the culture of sport hunting in India. These tips also followed the guidelines presented in shikar books, and also emphasized natural history and classification of animals. Isabel Savory often noted that natives incorrectly called marmots big rats or burra chuars as she wrote about the snowy regions of the Himalayas. The British were aware that Indians were often sketchy on varieties of animals and used their knowledge of natural history to show their superior qualities as sportsmen or sportswomen.

\footnotetext{
${ }^{379}$ Mrs. Barrett's Papers. Center for South Asian Studies. University of Cambridge, 6.

${ }^{380}$ Isabel Savory, A sportswoman in India: Personal adventures and experiences of travel in known and unknown India (London: Hazell, Watson and Viney, Ld., 1900), 84.
} 
Some women were also excited to learn about khabbar or news of an animal because they longed for trophies to display their prowess just as men did. Isabel Savory writes of her luck finding a snow leopard's skin and writes the following: " [It] was great news [as a] black panther's or snow leopard skin is one of the most precious trophy [trophies] a hunter can possess." ${ }^{381}$ Trophies have often been described as a masculine symbol, but women also valued them. Women anticipated that they would shoot an animal so they could obtain a trophy. To draw in an animal such as a leopard, a goat would be tied up in the vicinity of the spotting to lure it to the hunter and then the hunter and his or her party would wait for the kill. Sometimes the goat would die or sometimes the goat might be saved. In either case, the life of the goat was not that important as long as the panther was killed. While Isabel Savory can certainly be classified as a female with a masculine hunter's mentality since she wanted a trophy by killing an animal, which most women would find repulsive, yet her feminine side was still nevertheless present. She notes how after viewing a monkey being killed on a tea plantation and watching how hill monkeys take care of their young, she was "much grieved that it left an impression never to be effaced." 382 The image of mother and child often led women to feel sorry about the death of an animal. It was hard for them not to make the attachment of understanding, knowing that all female monkeys took care of their young. Many of them noted that this was something that really drew out guilt and sorrow after witnessing the killing of an animal especially since they were mothers and took care of their children. It

\footnotetext{
${ }^{381}$ Isabel Savory, A sportswoman in India: Personal adventures and experiences of travel in known and unknown India (London: Hazell, Watson and Viney, Ld., 1900), 94.

${ }^{382}$ Ibid, 95.
} 
was in the hunting field the similarities between wildlife and humans were engrained in women's minds.

Hunting was a way for British women to enjoy the grand Indian scenery. This point was more frequently made in women's accounts than in men's books. Hunting in colonial lands emphasized the greatness of hunting as a sport, which the British engaged in to impress not only their domination over the subject peoples of the Raj, but also over the immense variety of wildlife and landscape as well. One lady hunter summarized the imperial hunt by describing how luxurious and paradise-like the scenery was. She also detailed the wide variety and expanse of terrain available to the sportsman or sportswoman. The freedom to shoot where one pleases without any restraint was the mark of the imperialist. Mrs. Richard Tyacke wrote of "[t]he joy of shooting in these lovely mountains, in a perfect climate, where for shooting purposes the whole plan belongs to you where you take out no licence, pay no keepers, where the birds are bonafide wild ones, and take a lot of shooting, where you generally carry a rifle in addition to a gun, and run the chance of knocking over a bear or panther, as well as a pheasant." 383 India was certainly a hunter's paradise for women who had generally never before experienced such an immense variety of game and where low costs reigned supreme. The hunter Isabel Savory further noted that "[i]f only impecunious friends at home could be transferred to this land of plenty, of ideal climate, of ideal scenery, and ideal bills ! Our first week's expenses for living, for two people, are worth recording. We were said to have got through six chickens, one goose, one duck, and one leg of mutton;

\footnotetext{
${ }^{383}$ Mrs. Richard HumphreyTyacke, How I shot my bears; or, Two years'tent life in Kullu and Lahoul (London: S. Low Marston \& Co., 1893), 29.
} 
pears and apples for cooking every day, as many eggs and vegetables every day, and as much butter and milk every day as we could possibly consume; the whole of this, together with firewood and little etceteras, cost us not quite nine shillings. Add to this the trifling hire of a doongha and the small pittance of wages to two or three servants; take a tent, some books, sketching materials, and a gun; and one might roam over the Vale of Kashmir, and into its glorious mountains, from April to November, living upon a mere nothing and thoroughly enjoying the life." ${ }^{" 384}$ One of the imperial legacies was that India was open to the British for a few rupees for all the recreational sport one could indulge in as labor and food costs never stood in the way of the hunting and nature viewing experience.

Women, as Mary Procida has noted, filled in some of the duties of their husbands. Most men possessed the energy drive, and spontaneous 'ready to act' attitude that J.E. Carrington Turner and Jim Corbett possessed. These were qualities that most British sportsmen possessed, for each piece of news that was brought to them. Evelyn Smythies did not possess such qualities as he had lumbago and other physical ailments. However, Mr. Smythies possessed another asset, which made up for his shortfalls - his brave wife. Olive Smythies was known for "walking up and down a thousand feet" while hunting gural in the Himalayan mountains and upon news of a leopard, his wife took a 16. bore gun and Jankru Singh, her orderly, a goat

\footnotetext{
${ }^{384}$ Savory, A sportswoman in India, 190.
} 
for bait and a coolie and set off for the leopard because her husband was too tired to 'take care of the leopard.' 385

Evelyn Smythies also had a shooting companion in his wife as they both were armed with guns to kill a man-eating tigress after villagers told them about the death of an old lady attributed to the predator. She was also involved in searching for the remains of the woman. When Evelyn Smythies had official work to do his wife took up the remainder of the hunt (viz. sitting in a machan or platform with a buffalo bait waiting for the tigress to appear). She describes her experience as one that was nerve wracking but essential - imperially. Olive also shot a tiger that was 9 feet 8 inches. ${ }^{386}$ Despite Olive Smythies' bravery, there was still quite a bit of condescending attitudes towards female hunters for their perceived lack of knowledge in the hunting field. At a game bird shoot, Mr. Cox states "I said thirty yards not miles. Some of those birds you were wasting cartridges on at the end could not have heard your gun, much less felt it” and goes on to say “Well you can’t expect much of a bag if you shoot at high flying geese and duck with number eight shot." ${ }^{\prime 387}$ This made Olive felt dejected, however she states it was an important learning experience. The lack of small game hunting knowledge was seen as quite unfavorable.

\section{Hunting and Race}

The British sought to become the sole legitimate owners of the Indian jungles by

\footnotetext{
385 Olive Smythies, Ten Thousand Miles on Elephants (London: Seeley Service \& Co., Ltd. 1961), 23.

${ }^{386}$ Ibid, 29.

${ }^{387} \mathrm{Ibid}, 38$.
} 
legitimizing themselves as the only rightful hunters. British women shared the same negative attitude towards native hunters - if the natives hunted they did it for all the wrong reasons. For instance, a British lady hunter noted how zamindars or landlords in Kullu, a town in North India, obtained licenses for the use of guns strictly for the purpose of protecting their crops from the game, but instead "hundreds of pheasants are potted in the trees, and scores of chikor are slaughtered as they sit huddled together on a rock in the cold mornings. The birds are captured, especially chikor, and sold in different bazaars, where they are purchased for fighting purposes, to amuse fat and lazy natives, who delight in watching the poor creatures maim each other."388 These lazy, fat natives were certainly not the martial races that the British prized.

These ideas about race were formulated during the nineteenth century mainly through military conflicts. The Gurkhas' bravery and their loyalty to the British made them candidates for the martial race. Manly groups of people were identified by the British during the 1857 Rebellion, notes Heather Streets in Martial Races: The Military, Race and Masculinity in British India. ${ }^{389}$ These ideas were also formed through hunting experiences as certain types of Indians were viewed as pathetic fat men unworthy of the title of sportsmen yet other educated Indians were "good shots." Similarly, F. E. Penny stated that ram and cock fighting were quite common amusements engaged in by village

\footnotetext{
388 Tyacke, How I shot my bears, 18.

389 Heather Streets, The Martial Races: The Military, Race, and Masculinity in British Imperial Culture, 1857-1914 (Manchester: Manchester University Press, 2005), 11.
} 
men in South India. ${ }^{390}$ Cockfighting was derided as un-sportsmanlike. In Britain, cockfighting was associated with the working class especially in the $19^{\text {th }}$ century, and looked down upon by aristocrats and middle-class intellectuals and radicals who associated cockfighting with animal cruelty. ${ }^{391}$ According to Mrs. Tyacke, Europeans hunted for pleasure and did so in a grand style, whereas Indians threw rocks at animals and did not follow the necessary etiquette of using a gun and sitting on a elephant. As such, they were clearly not "sportsmen or sportswomen." Anne McClintock in Imperial Leather: Race, Gender and Sexuality in the Colonial Contest defines the shift from "scientific racism" to" commodity racism" where Indians and other colonial subjects could be reformed by adopting the correct commodities. The lack of proper commodities, however, was a sign of inferiority, and resulted in racism towards colonial subjects. If one used a gun instead of a rock, one could certainly be considered a civilized hunter. However, even when the natives used a gun, stigmatizing of them continued as it coincided with the decline of game that was quite noticeable to European observers by the 1890 s.

As imperial protectors of the jungles, Europeans felt they needed to restrict the threats on Indian wildlife. The most serious threat was seen to be native shikaris, who used guns in excess. Gentlemen tried to persuade the shikaris to hunt less and kill fewer animals. Mrs. Alan Gardner noted that "Alan [her husband] tried to impress upon Rahman that if game became extinct it would not be long before the shikari followed

\footnotetext{
${ }^{390}$ F. E. Penny, Southern India (London: A. \& C. Black, 1914), 181.

${ }^{391}$ Richard Holt, Sport and the working class in modern Britain (NY: St. Martin's Press, 1990), 13.
} 
suit." ${ }^{\prime 392}$ Sustainable hunting was something the British felt they had an obligation to practice and to teach native hunters to practice. Imposing restrictions on hunting was also part of the burden that European women were obliged to inculcate into their Indian subordinates. Her activities thus fit the traditional imperial role for women: to teach Indians to better themselves. Mrs. Alan Gardner was well aware of the repercussions of hunting in the colonial tropics, for she was afraid that Indian animals could become extinct like the dodo of Madagascar. She developed this ecological awareness, most likely through instruction from her husband. Edward Said's premise of the active West changing the East in Orientalism through continuous instruction resonates with the ideals of women who sought to save the shikari from himself.

According to certain British officials and non-officials, villagers did not have the qualifications to undertake the killing of the tigers because they did not use the right techniques associated with the hunting etiquette and because they were not masculine enough. These British officials alleged that women used guns whereas natives did not, even though in reality many of them did. The emphasis on gun usage was a construction to legitimize British control over hunting. A British lady hunter noted how "in Kullu [a town in Northern India], the inhabitants are a degenerate race of Hindoos, and the biggest cowards in Asia. It is useless to expect them to keep line if a bear is anywhere within a mile of them. They move about the jungle in gangs, each trying to get the other to go in

\footnotetext{
392 Nora Beatrice Gardner, Rifle and spear with the Rajpoots: being the narrative of a winter's travel and sport in northern India, by Mrs. Alan Gardner. Illustrated from photographs and sketches by the author and two drawings by F.H. Townsend (London: Chatto \& Windus, 1895), 50.
} 
front, and utterly regardless of direction, Now there is absolutely no danger...All wild beasts will sneak away from a human being." ${ }^{\prime 393}$ The lady hunter seems to suggest it was pointless to have a native hunting brigade to accompany the sportsperson, since the Indians were all "cowards." Just as Sinha noted the British image of Bengalis as 'effeminate' compared to their own 'manliness,' so in hunting gender became a surrogate for race and British women portrayed as feminine by British manly men. This phenomenon is modified in the hunting arena as gender becomes a surrogate for race. British women portrayed North Indians as feminine. The bravery and unsqueamishness of the Europeans, whether man or woman however, was only another construction that rationalized European rule on the premise that they could withstand the dangerous, masculine sport of hunting. This was also part of the larger contradictions displayed by Europeans who tried to shut out Indians from hunting while simultaneously relying on shikaris for hunting purposes.

Similarly, Isabel Savory notes that Indian shikaris need to be supervised otherwise they will not act responsibly. She writes "In Mysore there are strict game laws, but in Central India there are none, and as a result the native village shikaris are rapidly ruining the country. These shikaris shoot simply for food; and as they kill hinds, does, young, etc., indiscriminately, there are no deer left. They avoid tigers, panthers, and bears, as a rule, partly because their guns would seldom kill them and they themselves would run considerable risk, partly because these animals are of little use for eating

393 Tyacke, How I shot my bears, 32. 
purposes." ${ }^{394}$ Here Savory shows that the native hunters' lack of superior commodities, in this case European-made guns of newer stock as well as their lack of restraint are seen by the English as unsportsmanlike. Not following the rules of hunting etiquette was certainly another mark that showed that they were not qualified to be deemed as sportsmen. In contrast, British women were seen as imperial because they followed the hunter's rules of etiquette and demonstrated what was considered a masculine restraint by refraining from excessive shooting. The British also looked down on subsistence hunting because they considered recreational hunting the norm.

In a similar way, Mrs. E. Barrett noted the fact that Indians indulged in nonsportsmanlike activities such as shooting from a motor car. She emphasized the fact that technological improvements to hunting raised doubts about shooting as sport. When referring to blackbuck shooting by motor car, she wrote "I returned from that outing convinced that blackbuck shooting from a car, if not a sport, was at least an exhilarating pastime, with the odds heavily in favour of the buck." ${ }^{395}$ Her first-hand experience goes against the popular notion that motor car shooting led to an obvious advantage for the shooter as opposed to his target. Mrs. E. Barrett was very influenced by many British male sportsmen who derided motorcar shooting as unsportsmanlike, yet she nevertheless participates in such hunting.

Women were complicit in the move to demarcate Indian shikaris as unworthy sportsmen. Many women blamed the shikaris for the lack of game for their husbands'

394 Savory, A sportswoman in India, 279.

${ }^{395}$ Mrs. Barrett Papers. Center for South Asian Studies. Cambridge University, 5. 
small "bags of trophies." Women did not blame their husband's bad shooting skills for a small "bag" of animals. Instead, it was the shikari who was blamed. H. Ovcoy writes that "H. went out shooting at three, but only brought home two snipe and a quail, with three Shikaries to help him!"’396

In an effort to differentiate the British from the natives, many claimed shikaris were useless. Thomas Metcalf writes in Ideologies of the Raj of the differentiation that emerged between the British and the Indians after the Mutiny. ${ }^{397}$ This is similar to the hunting arena where the British demarcated Indian shikaris from being worthy sportsmen. Isabel Savory writes that the "shikari Lalla proved to be a plausible old villain. Kashmiris are not show-specimens among mankind: lazy, cunning, liars; if they constitute, as people say remnants of part of the lost Ten Tribes of Israel, who would be an Israelite? They are certainly Jewish-looking-dark, with hooked noses."${ }^{\prime 398}$ Here rabid anti-Semitism is mixed in with racism as the British sportswoman tries to stain the Kashmiri shikari's reputation for no apparent reason. Isabel Savory then fits the typical mold of the memsahib who is prejudiced with middle-class Victorian sentiments on race. Margaret Macmillan in Women of the Raj agrees that the typical memsahib was quite racially prejudiced.

It was not only shikaris who the British women felt were beneath them, but Indian

\footnotetext{
396 Ouvry, M.H, A Lady's Diary Before and During the Indian Mutiny (Lymington: 1872) British Library, 1854-1892 T36871, 21.

397 Thomas R. Metcalf, Ideologies of the Raj (Cambridge: Cambridge University Press, 1994), 67.

398 Savory, A sportswoman in India, 155.
} 
women as well. British women had an imperial relationship with their servants who attended their hunts. Isabel Savory notes how

An ayah [wetnurse possibly a Muslim or low-caste Hindu] cannot walk; she is bound to ride. Supposing you wish to go over country which is impracticable for mules, coolies will carry your kit; but it is annoying to be obliged to have four extra coolies to carry a servant. In a tent, what is there for her to superintend? dust? My own experience of one on a march was that she was always behind or in difficulties on the road; that she arrived at night tired, grumbling, and useless; and was, in fact, out of temper from the time she left our own compound until the evening we arrived back again. Sala Bux [her servant] did all I wanted, as far as getting hot water $[\ldots]$ he made my bed, brushed my clothes, cleaned my boots, and packed my bedding. His head was filled with something other than brains, certainly; but he was a well-intentioned fool. ${ }^{399}$

As this passage suggests, the Indian ayah or female nurse maid was considered too feminine for British women's sensibilities. This is a new Anglo-Indian construction of women by their character. They were not hardy enough as they could not hike and constantly complained about the excessive amounts of work that they had to do unlike strong British female hunters who adapted to rough terrains. Indian men, while still portrayed as foolish, worked hard while not complaining. Domestic manuals such as The Englishwoman in India emphasized that ayahs were necessary. British women's masculine overt attitudes and prejudices led them to be more likely to side with their male servants because they were more subservient to them and hardly ever complained. This was seen as respectable and earned the imperialist's favor.

\section{British Women as Hunters}

${ }^{399}$ Savory, A sportswoman in India, 152. 
Women also enjoyed the fruits of the hunt. Isabel Savory noted how "S. shot a brace of ram chikor, a sort of large pheasant, grey with red legs - handsome birds and very good to eat." ${ }^{400}$ Hunting allowed women to enjoy the great variety of foods beyond the usual fowl and mutton that appeared on the Anglo-Indian dining table. Quails and pheasants were particularly sought after as fine gourmet meats. This was seen as quite feminine to be concerned with trifling matters like foods. The concern for tasty, gourmet dishes also highlight women's femininity in connection to the sport of hunting.

The fairytale experience was one more feminine trait that was very marked in the regal hunt. In colonial India, hunting was the privilege of the elite, royal minority and other selected British and Indian guests. The Maharajas were also critical in helping host shootings for the British, since they opened their hunting grounds to various dignitaries. The maharajas were also crucial in lending elephants, an entourage, and supplies such as tents to help ensure the hunt would be regal and up to the standards required by the British. Following the regal hunt, there would be a great feast of Mughal dishes along with an exchange of gifts. This lavish experience was full of excesses. George Eden's (Lord Auckland) regal hunting expedition, for example, included 12,000 people. ${ }^{401}$ It was organized by the Sikh ruler Ranjit Singh. The grandness of the regal hunt was a symbol of elite hospitality. Similarly Isabel Savory, for instance, was invited to Mian Mir by Maharajah Jagatjit Singh Bahadur whose guest house was complete with a French chef.

\footnotetext{
${ }^{400}$ Savory, A sportswoman in India, 236.

${ }^{401}$ Eden, Tigers, durbars, and Kings, 7.
} 
The fairytale like experiences that British women enjoyed were almost exclusively the result of a maharaja's invitation to his palace compound. One such hunting expedition occurred in the princely state of Jaora on Christmas in 1933. Mrs. E. Barrett noted the beauty of the palace's garden and surroundings. She wrote " $[t]$ he air was warm, and smelt of dust and spice and jasmine, the stale, sweet scent of India. Overhead stars glittered, stars so brilliant that it seemed one had but to stretch a hand to pluck one from the sky. I longed to walk into the night, to be lost in this stillness and brilliance" as she describes the mesmerizing qualities of the picturesque scene. $402 \mathrm{Mrs}$. Barrett also accompanied the princes for blackbuck shooting from a motor car. She wrote that "[n]ever have I seen anything more lovely than those exquisite small buck, coloured ebony and pearl, in soaring flight against the pale sky of an Indian dawn." ${ }^{403}$ The immense beauty of wildlife was highlighted in women's writings on hunting more than in men's memoirs and publications. Men were more concerned with describing the thrills of hunting and the colors associated with different species; although men did refer to the beauty of nature, they rarely stated the beauty of game.

Women wrote highly of the privileged, special treatment they received during scheduled hunting events. All of the ladies would receive special gifts from the maharaja and they were included in shooting expeditions as well. Mrs. E. Barrett writes how she "went duck-shooting for the whole day" arriving to the duck-shooting destination in a motor car. During these shooting expeditions, there was really no limit set on how many

\footnotetext{
${ }^{402}$ E. Barrett Papers. Center for South Asian Studies, Cambridge University, 1.

${ }^{403} \mathrm{Ibid}, 5$.
} 
duck one could kill and destinations were usually picked in which ducks were numerous in order to afford "good sport" for guests. In addition to duck, Mrs. E. Barrett also wrote of killing three jacks. Part of the invitation of the maharaja, also entailed a special visit to the zenana or women's quarters where women met the maharani and other women. European women were highly privileged in that unlike women in the zenana who were enclosed in a purdah-like atmosphere, they got to attend the dinner parties after the hunting expeditions and got to be in the presence of other men where the maharani and other women of the zenana did not. Many women, like Mrs. Barrett, questioned the maharaja about Indian women's absence from hunting-related events. This also helped emphasize the privilege that British women had - hunting - which put them a step ahead of the "oppressed" Indian females.

Some women did not want to hunt and so it makes sense that they disliked seeing animals killed. Others liked to hunt. Women who did not like to hunt probably did not choose to hunt, but rather some women resisted hunting and came along only under duress. Constance Sitwell notes how she "became sporting [...and how] I hadn't been here two days before I was made to hunt." ${ }^{" 404}$ She was accompanied in India by her brother who presumably introduced her to the sport of hunting. The commonality of hunting meant that not only British men but British women hunted as well. Some women placed themselves in danger just because of the craze of hunting.

The non-feminine nature of hunting often led many women who participated in hunting events to be viewed with concern because of their lack of conformity to female

\footnotetext{
${ }^{404}$ Constance Sitwell, Flowers and Elephants (London: Jonathan Cape, 1927), 56.
} 
norms. This was particularly true in Britain, more so than in India, because women were seen as part of the imperialist enterprise in India. Maudie Ellis writes of Mrs. Cheape's French governess who believed that "these activities were as unusual as the little short skirts she wore (without crinoline). [...Mademoiselle stated] She has such beauty and loveliness, but does not seem to know of it, and cares nothing for the fine clothes she should wear nor the young gentlemen's compliments." ${ }^{405}$ Mrs. Cheape's love of hunting was seen as an oddity. Perhaps in the $19^{\text {th }}$ century, these women were odd. The French governess was not an aristocrat and therefore her views are inconsistent with the majority of aristocratic circles of Britain, who accepted women in the hunting field. Anglo-Indian women were viewed as odd by Indian men as well because of their presence in the hunting field, however Indian men accepted the place of Anglo-Indian women in the hunting arena because of their imperial standing. Mrs. Cheape's French governess believed that a young lady should be more concerned with fine dresses and young gentlemen along with preserving her beauty. The lack of conformity with Victorian society's ideals for young women was rather distasteful to the French governess, who had no admiration for the young woman's attachment to the sport of hunting.

Victorian society did not encourage female hunting even though it was permitted among hunting families. Lieutenant Colonel E. D. Miller who served the $17^{\text {th }}$ lancers in Lucknow in 1887 highlights the prejudice against women and girls who participated in hunting events in Britain. In his published book, Fifty Years of Sport he wrote "[m]y two elder sisters were just as fond of hunting as their brothers, but our parents did not approve

${ }^{405}$ Maudie Ellis, The Squire of Bentley (Mrs Cheape): Memory's Milestones in the Life of a Great Sportswoman (Edinburgh: William Blackwood and Sons, Ltd., 1926), 16. 
of this form of sport for girls, so they only got a rare hunt now and again when I took

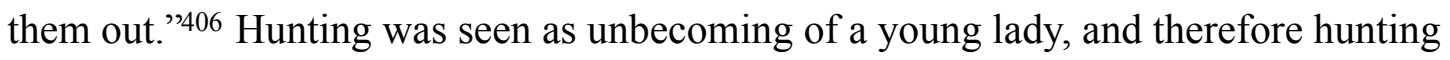
was not encouraged among most young women. Although hunting in Britain was by no means an equal field especially in the $18^{\text {th }}$ century, by the $20^{\text {th }}$ century women were on par with men in the hunting domain. In The Politics of Hunting, Richard Thomas states that "Before 1850, only the wives and daughters of aristocrats and owning Masters were acceptable in the hunting field. Gradually numbers of women in the hunting field increased; the aristocrats [were] joined by the wives and daughters of farmers. ${ }^{{ }^{4} 07}$ The shift making it acceptable for women to hunt coincided with the growth of the women's suffrage movement, which began in the 1870s and increased demands for parity. An increasing presence of women in the workplace may have contributed to equality in the hunting arena as well.

By the late $19^{\text {th }}$ century, women began to be more prominent in the hunting field in Britain. Typically, as in India, the wives, and occasionally sisters or daughters of the male sportsmen attended hunting events. Mrs. Cheape wrote in her diary that "Mr. Turnbull's little girls out, appearing to enjoy themselves; very keen, and plucky cub hunting." ${ }^{\prime 408}$ These girls also had great fun amusing themselves in the chase of the fox. As wives, they were often permitted to join their husbands in the hunting field and found great companionship in these hunting trips. Mrs. Cheape's husband, Colonel Cheape

\footnotetext{
${ }^{406}$ Lieut.-Col. Edward Darley Miller, Fifty Years of Sport (London: Hurst and Blackett, Ltd., 1925), 18.

${ }^{407}$ Richard H. Thomas, The politics of hunting (Aldershot, Eng.: Gower, 1983), 53.

${ }^{408}$ Ellis, The Squire of Bentley, 88.
} 
served as Master of Foxhounds in the Fife country in Scotland, where she often accompanied her husband. Women by the late $19^{\text {th }}$ century began to serve as Masters of Foxhounds. An example of a female Masters of Foxhounds and Master of Harriers was Mrs. Cheape. Her daughter, Maudie Ellis wrote her biography and integrated several accounts from her diaries, which recorded her hunting experiences. Ellis captures the joy that Mrs. Cheape experienced from her account dated December 31, 1881. Mrs. Cheape wrote "'Marquis' jumped the brook beautifully. Found our second fox near Hadzor. Had a gallop of an hour and twenty minutes. A beautiful hunt, and such a lot of jumping!"’09 Long horse rides coupled with beautiful countryside gazes were categorized as good sport. Lots of jumping equated to more exercise and adventure. Therefore, atypical activities for women often renegotiated the feminine ideal of women being frail and fragile and helped portray women in a new light where they were feminine when they needed to be, yet masculine in their taste of recreational pursuits.

\section{Conclusions}

The hunting experiences of women complicate and renegotiate the masculine narrative attributed to the sport of hunting by emphasizing the fact that femininity can also be associated with hunting and women may espouse masculine traits at times. Hunting as an exclusively masculine sport as defined by Joseph Sramek is therefore contested. Whether as spectators or actual participants of the hunt, some women were

\footnotetext{
${ }^{409} \mathrm{Ibid}, 88$.
} 
feminine yet had masculine traits while other women were entirely feminine and did not condone hunting. They were certainly active partners in the hunting field with their husbands or other male companions. The sport of hunting brought women out of the domestic sphere of the home and into the larger environment of British India. Their experiences with Indian natives expanded through the hunting experience. Women either as spectators of the sport or actual hunters were viewed as great oddities and the natives honed in on their difference to stare, observe and gaze at these women with great awe and wonder. Some of these women were quite prejudiced, however there were some that felt an immense amount of emotion for the death of animals at the hands of hunters and were thus precursors to the conservationist movement.

\section{Chapter 7: Regulation of Hunting in the late $19^{\text {th }}$ and $20^{\text {th }}$ centuries}

The Anglo-Indian tradition of hunting was solidified by the late $19^{\text {th }}$ century when the British began to hunt with Indians and traditions of hunting amalgamated together. The amalgamation occurred as Indians and British hunted together and employed each other's methods. The late $19^{\text {th }}$ century also witnessed the rise of legislation designed to restrict the hunting of game. As the Anglo-Indian tradition consolidated, however, a series of problems developed in Indian hunting, especially a decline in game, and scientific and political awareness of environmental issues grew widely in the British Empire. This stimulated policies to protect the environment in many 
colonies. These problems and these new environmental concerns led to substantial change in Indian hunting, which led to the introduction of legislation designed to curtail and restrict hunting. These conservation policies had the aim of restraining Indian hunters in their 'excessive' pattern of hunting. In application, these policies showed that many Indians could adapt to new information and circumstances. Hunting laws were simultaneous with the steps the $R a j$ was taking to move towards independence.

In the late 1880s the government took up the question of whether an allencompassing game law was necessary. The government decided that there was no underlying reason why game needed to be protected by an all-encompassing law and believed that the best thing to do was to leave game laws to local governments. The Punjab government proposal was upheld, rather than a federal solution for game preservation. The Punjab government proposal entailed that local governments would have the power to close hunting for any particular season as it saw was best in order to protect extinction of game or birds. Local governments would have extensive knowledge of the rareness of particular types of animals or birds therefore a grassroots attempt at game preservation was to be more successful. Soon, a flurry of acts, as well as a system of licenses and bills would appear for each region and locality.

\section{Game Legislation}

In 1887, for example, the Wild Birds Protection Act was passed that helped to protect game in India from rapid decline. By the 1920s, local orders were passed that further regulated the killing of game. In Quetta, for example, the government 
implemented a law where there was a Rs. 50 fine for shooting game birds when not in hunting season. Other British dependencies also wished to follow the Indian model, often citing Indian laws when deciding whether to institute similar legislation. For example, the Aden Residency questioned whether to protect game birds such as chikor and sandgrouse by closing shooting seasons for a particular time period within the year. ${ }^{410}$

The Madras Game and Fish Preservation Bill led to the Madras Game and Preservation Act of 1893. However, its passage from a bill to an official government act did not occur without reservations and debates on whether additional amendments were necessary. Sir Charles Turner, a prominent member of the Secretary of State for India's Council, believed that this bill would limit the supply of meat for the Indians who hunted game. The bill was also believed to hurt farmers who would suffer financially from crops destroyed at the hands of wild game. Reputed experts on native affairs debated whether protection of wild game would adversely affect tribal peoples and local farmers. Reports from the collectors of Salem and Madura showed that tribals residing in the Palni and Shevaroy Hills had stopped hunting and no longer obtained most of their food from game. No amendment to the bill was necessary deemed native experts. Similarly, the collector of the Nilgiris believed that no additional legislation to protect fish was necessary for tribals who ate fish. The collector of the Nilgiris also consulted sportsmen for facts about game declines and tribals' habits concerning game mainly because sportsmen had first-hand accounts of this information.

${ }^{410}$ Game Laws. British Library. IOR: R/20/A/2901 File No. 292/1. 
Evidence of a concern for the declining numbers of game culminated in the Madras Game and Fish Preservation Act of 1893 and a system of licensing which was implemented in all districts by the $20^{\text {th }}$ century. The Forestry Department had jurisdiction over the issuance of permits for hunting purposes. In some cases, residents of royal states issued licenses to sportsmen. However, some maharajas had secretaries who issued them. There were extenuating circumstances even in the 1930s where letters from Maharajas served as permits for hunting. Hunting licenses were usually granted within a couple of days. In native states where licenses were not issued, Maharajahs usually granted permission to hunt by accompanying guests to their preserves.

Yet even though the imperial government implemented restrictions on hunting, it was quite lenient where humans, domestic animals or crops were in danger. The government reward for the killing of tigers, leopards, deer and pigs still continued well into the $20^{\text {th }}$ century. The British government was concerned about the possible decline of tigers and leopards due to the reward, however they were of the opinion that the possible dangers to humans and crops outweighed the possible reduction of tigers. The Secretary of State for India, Mr. John Morley, wrote on July 10, 1906 that "I do not consider that the discontinuance of these rewards is advisable" in response to a question posed by Mr. Rees. ${ }^{411}$

Nonetheless, during the $20^{\text {th }}$ century, there was a conscious effort to restrict indiscriminant shooting. This phenomenon would change the nature of the imperial hunt. It was no longer about how much game one could bag. The pleasure that was derived

\footnotetext{
${ }^{411}$ House of Commons Question on the Indiscriminate offer of rewards for the destruction of Tigers, 10 July 1906. British Library. IOR/L/PJ/6/769 File 2067.
} 
from the hunt no doubt remained. However, most hunters in the $20^{\text {th }}$ century were aware that they could not kill large numbers of game without repercussions. The mark of the imperialist changed to one who displayed restraint and carefully followed game laws. The rise of environmental concerns and active benevolence emerged in the $R a j$ with the rise of game legislation that was designed to thwart the decline of certain species of game. A lack of clear directives on game preservation led to the proliferation of Annual Game Preservation Reports that directed efforts on game preservation. Experts such as government officials and sportsmen were referred to in order to understand and curtail poaching and tribal activities in the hunting arena. These measures were largely successful, however, there were still instances of deviance.

\section{The Fight Against Poachers}

This new legislation which appeared at the end of $19^{\text {th }}$ century also affected relations with Indians. There was a widening gap between the British Government and sportsmen and Indian poachers. Where they had often served each other in the past, new legislation and the government's effort to eradicate unsportsmanlike hunting reinforced this widening rift. The government attempted to dismantle the traditions of poachers as it prohibited poaching-like activities that involved the stealing of eggs of jungle fowl and peafowl, dynamiting of fish, and the setting of traps and snares for game-catching. In addition poaching like activities such as the shooting of crocodiles with flashlight was banned. The concern with the depredations of poachers filled the Annual Game Preservation Reports with offences of poachers. 
Game Preservation Reports in 1936-1937 show that suspicion was quite rampant among officials in government who suspected that the war against tribals and their poaching activities was far from over. For example, Game Preservation Reports stated that the Mechias of Assam who were rhinoceros poachers were under government surveillance to curtail their poaching.

By the 1930s the Government of Bengal initiated a major effort to record the decline of game. The Annual Report on Game Preservation in Bengal was published throughout the 1930s. Game preservation reports detailed conservation efforts. In 1936-1937 five blocks (Dubla, Katkar, Dhondal, Dakshmir Mandarbaria, Talpatti Maidan) were closed to hunting in order to protect the species in the Sunderbans. Shooting passes were also restricted to reliable sportsmen which more than likely had the objective of denying passes to tribals. New sanctuaries were added and recorded in the Forestry Department's Annual Reports records, the governing body which oversaw the administration of the sanctuaries. In 1938 the Senchal sanctuary was established to protect all species of game except bears and a Mongpong (sanctuar) was established to protect game including birds. The Raj also employed forest guards under the Government order No.106 22-For (25 August 1932) and a temporary Deputy Ranger under Government Order No.346T-For (21 May 1938) to protect Rhinoceros. ${ }^{412}$ The forest guards were to keep watch over the forests. One of their primary duties was to ensure poaching or illicit shooting did not occur.

\footnotetext{
412 Bengal Forest Department Annual Report on Game Preservation 1935/36-1938-1939. IOR/V/24/1701. British Library.
} 
The Bengal government passed The Rhinoceros Preservation Act of 1938 which posted temporary deputy rangers to thwart the designs of tribal 'poachers.' Additional laws set steep penalties on poaching, hunting without a license, or not following the rules of the hunting license. For example, in 1938 in the Sunderbans poachers were caught with 78 iguana skins. These men had to pay a fine of Rs.3.00 for each skin. The Divisional Forest Officer was also responsible for recording the decline of game. The decline in a certain species was often attributed to increased poaching. For example, the Divisional Forest Officer speculated that few crocodiles can be found in Bengal due to heightened poaching. These statistics in many cases were not scientifically derived. A lack of experts was one problem that marked game preservation reports in India.

Evident in the policies of the Bengal Forest Department was the widening demarcation between the sportsman and the poacher. Gun licenses were denied if the applicant was not a member of a reputed shooting club or official association such as the Tista-Toorsa Game Association. Educated Indians and British sportsmen were almost always members of such prestigious organizations and did not have to worry about a license refusal, whereas poachers were of a lower class and not members of any recognized associations. Membership in a reputed association such as the Nagpur Hunt Club cost Rs. 50 per year for full member status. Cost was certainly the defining factor that explained the lack of tribal membership in such organizations. They often had to resort to using unlicensed guns. The Divisional Forest Officer was well aware of this loophole. To combat this loophole, forest officials were sent to gather and collect these unlicensed guns. After 1938, this intrusion into suspected people's homes ended. 
However unlicensed guns continued to arrive from Nepal. The steep penalties for illicit game shooting were sometimes dropped when there was no evidence. Some illicit hunters were given warnings that shooting offenses could also result in a court case. In some cases the government leased out portions of the forest to be protected by a third party. For example, Reserved Forest of Darjeeling, Kalimpong, and Kurseong Divisions were leased to the Darjeeling shooting and fishing club for hunting and protection from poachers. In addition to associations and clubs, tea garden managers also helped prevent poaching by their coolies and certain tea garden managers were empowered to act as forest officers.

Hunting offenses continued to rise despite the efforts of the Department of Forestry and select game associations or shooting clubs. The Department of Foresty enlisted the services of game associations to become their right hand in curtailing illicit shooting. Therefore, sportsmen were never the target, but the unsportsmanlike poacher was the target of the game laws enacted by the imperial government. During 1938-39 there were 102 cases of illicit hunting from eight divisions (Darjeeling, Kalimpong, Kurseong, Jalpaiguri, Buxa, Sunderbans, Chittagong, and Chittagong Hill Tracts). ${ }^{413}$ The highest number of illicit shooting cases occurred in the Sunderbans, the location where most of the game flourished.

The government began researching information on poaching in order to take the appropriate steps against it. Government officials also began the task of compiling lists of game that needed to be protected due to their high demand for trophy keeping purposes.

${ }^{413}$ Bengal Forest Department. Annual Report on Game Preservation 1938-1939. IOR/V/24/1701. British Library. 
W.R. Fisher, the Conservator of Forests in School Circle, NWP, sent the superintendent of Dehra Dun a list of 10 birds which are shot primarily for their skins. This list included such birds as jays and magpies along with woodpeckers and kingfishers. Parrots were not on the list because they caused havoc to crops and many farmers would be affected by a rule that prohibited shooting of parrots. Nevertheless, an urgent request from W. R. Fisher to stop bird shooting for their skins was sent to the Superintendent.

Government officials were quite suspicious of native shikaris and cultivators who killed animals because of crop or livestock damage. J. Nisbet, the Deputy Conservator of Forests in Rangoon, Burma, wrote an official letter that detailed the fact that marshdeer, hog deer, barking deer and sambar were often killed in the rainy season by shikaris and he recommended closing hunting from the beginning of July to the end of October (the monsoon season) to protect the aforementioned deer. Yet the British Indian government encountered much conflicting information on the peak locations and seasons of different game. Another British official wrote that hunting increased exponentially during nonmonsoon months. British officials emphasized the fact that winged game was snared/ shot during breeding seasons. This was seen to be very destructive because if game were killed during the times that they were suppose to reproduce then there would not be sufficient partners to mate and mating patterns/opportunities would be disrupted. The British official also noted that restricting the sale of game during a particular season did not help because fresh deer meat was smoked and dried throughout the year so it would not help protect animals all year around. 
Most British sportsmen likened shikaris to poachers. An exception was E.W. Oates who noted the activities of Burmese shikaris in order to formulate an argument on whether preservation of game was necessary. He wrote that measures were necessary to prevent the extinction for Thamine and Daray since Burmans indiscriminately killed these two species in the Pegu and Hanthawaddy Districts, often selling these deer at bazaars. The concern for the Thiamine deer also led to an internal government investigation on how to protect this animal in $1938 .{ }^{414} \mathrm{He}$ observed that game birds were safe from Burman shikaris, because they did not eat them and preferred birds like cranes or herons, which although they trapped or shot did not sell at the bazaars and their children did not destroy the eggs which he states British children tend to do. The respectful nature of the typical Burman shikari towards game birds translated to the fact that winged game was not under any visible threat. In contrast to Oates, however, most British officials had a very condescending attitude towards Burmese shikaris who they believed were wholly responsible for game destruction. A British official noted that Burmese and Karen shikaris constantly hunt when they get a chance using traps and snares. The lack of a closing season for game was also viewed as a lack of restraint by tribals who relied on game for subsistence. Eggs stolen from nests were orchestrated by the Karens and was condemned.

\section{Decline in Game}

\footnotetext{
414 B199/39 Protection of Wildlife in Burma, protection of Thiamin and Giant Panda IOR/M/2/1588 17 Nov 1938-May 1941 British Library
} 
Hunting and poaching were not the only reasons for the decline of game. Wild animals were affected by disease, and the clearing of jungles. Clearing of jungles was caused by the felling of trees along with expansion of cultivation into the jungles. Just as in East Africa, rinderpest was a serious problem that affected gaurus. While rinderpest is a disease that affects cattle, it could also infects wild animals such as gaurus. Sanctuaries helped protect gaurus from cows that were infected. Selective hunting due to game laws also decreased further breeding of baby wild animals. Game laws that restricted the shooting of spotted deer to adult stags led to a proliferation of does. Efforts to ensure female does could advance to full term pregnancy led to a shortage of males because of the targeted killing of adult males.

The expansion of cultivation at the expense of forest lands also led to the decline of game. The Indian subcontinent already had a high population density during the colonial period and farmers were increasingly interested in pushing back the forests, reclaiming forest lands for cultivation and expanding villages. This conflict was at the heart of the reason for the declines of game. The wild animal's ecosystem was disturbed by the need for farming for the economy and subsistence for humans.

Divisional forest officers also recorded the plentiful species and the types of game that were flourishing in their respective forest divisions. It is difficult to assess the exact year that declines began, since I have only obtained Bengal government records for a few selected years in the 1930s, but most of Bengal by the 1930s had no deer except for the hog deer in the Toorsa and Titi forests of Jalpaiguri, and larking deer in Darjeeling. This was most likely due to shooting of deer for sport. Clearly, the sportsman was primarily 
responsible for the absence of deer in other divisions. Yet, the Department of Forestry was more concerned with the suppression of poaching-like activities.

Poaching activities admittedly helped contribute to the decline of game. Reasons for poaching are outlined in books by British sportsmen and official government documents such as the Annual Game Preservation Reports. Poachers sought particular animals for subsistence or for potential market value sales. A market existed, for example, for rhinoceros horns as an aphrodisiac or as an anti-poison medicine. Native hunters also used tiger fat and whiskers as medicine, and for a cure for impotence and rheumatism, or kept their claws as charms and skins for decorative purposes. Active poachers also killed animals for sheer subsistence. The deer family which included Sambhar, Chital, Barking Deer, Hog deer, Swamp deer and Gaurus, Pigmy hog and Ghooral was an important food source. Hunting for subsistence purposes was much less respected than hunting for sport and recreation, which was categorized as activity worthy of any respectable British or Indian man.

There was, however, significant concern with dwindling numbers of game among certain British officials and residents. The development of environmentalism led to the formation of organizations whose main goal was to protect game animals. The Game Federation of Bengal was one such organization. In addition to protection, the aforementioned organization also was responsible for introducing certain new species of game to Bengal.

The efforts to protect declining levels of game often conflicted with the need to protect villages from damage and destruction caused by wild animals. Extremely 
troublesome elephants would be shot, thereby allowing the divisional forest officer or his subordinate to exterminate game if it did not "cooperate" with other animals or humans in the jungle. The government's response to the damage caused by wild elephants led to khedda operations where wild elephants were rounded up and sold at depots. Wild elephants caused the most damage to tea gardens, crops, young seedlings, trees and people. There were instances of destruction by sambar (deer), wild dogs, bears and leopards. These instances often had an impact on how many licenses were issues to eradicate the "problem" game.

Game preservation reports also detailed the numbers of shooting permits that were issued which showed that hunting continued. In 1938-39 in Bengal, there were 592 such permits granted and there were 3,318 game birds, hare, porcupine and jackals killed in the forests of Bengal. ${ }^{415}$ Chital and barking deer were the second highest types of game killed, followed by tigers. The numbers for large game such as tigers were quite modest as only 42 were killed. Game preservation reports also distinguished animals such as stags that were shot but not killed at the hands of the hunters. It was deduced that these animals died from maggot infested wounds.

While the annual game reports of Bengal suggested declines in certain species of game, there were areas were game remained plentiful. Although the British were quick to point out that tribal hunters relied on game for subsistence thus contributing to the decline in game, Europeans also ate the fruits of the hunt and therefore a double standard was implemented because some game (those that graced European tables) was seen as

\footnotetext{
415 Bengal Forest Department Annual Report on Game Preservation 1938-1939. IOR/V/24/1701. British Library.
} 
acceptable to eat. Official government records indicate the rise of bazaars that stocked snipe, teal and jungle fowl which were purchased by Europeans who had their servants cook the game for their lunches or dinners. This game was typically sold by madrasis, who caught these game birds and took them to the bazaars for sale.

Another reason that game declined stemmed from the incentives that shikaris had to 'bag' wild animals for one's sahib. Shikaris were employed by hunt clubs to facilitate good shikar. Employment of shikaris was also standardized. By reviewing the by-laws of the Nagpur Hunt Club, one can see that shikaris were critical to the hunting process. Shikaris were paid Rs. 15 per month and they were paid Rs.12 any month that hunting was not conducted. ${ }^{416}$ This meant they were paid for their on-call status. In addition, for every boar that was killed, one rupee was awarded to the shikari, which gave them an incentive to ensure that boar would be killed.

\section{Efforts by the Government and Private Clubs to Curtail Game Declines}

Hunt clubs also took the lead to champion protection of game. The by-laws of the Nagpur Hunt Club details their protection laws. Article number 25 states a member must pay a fine of Rs. 5 if he spears a pig shorter than 24 inches. ${ }^{417}$ This measure was designed to protect young boars from indiscriminate spearing methods that would give the pig sticker an undue advantage. For example, wearing such clothes that hid the person from view of the pig was prohibited and a fine of Rs. 3 was instituted for failure to follow that policy. The interest to conserve game was coupled with hunting etiquette.

\footnotetext{
${ }^{416}$ Nagpur Hunt Club. Mss EurA225. British Library.

${ }^{417}$ Nagpur Hunt Club, Mss Eur A225. British Library.
} 
Even though many hunters took pride in the fact that they restrained themselves and followed the proper protocol for hunting, which meant applying for a license and abiding by local rules, they were also responsible for the decline in game due to their obsession with large trophies. The government was aware of this and took steps to prevent it. Correspondence from the Revenue Department of the Government of Madras proposed that a minimum size of horns would prevent the numbers of young male game from declining. Young buck and ibex were often shot and left in the forests because their horns were too small for a hunter to keep as a trophy upon a wall. The views of game association members, such as the Nilgiri Game Association President and others, were taken into account before the final draft of the bill was passed.

The government was most concerned with game that British hunters favored. Government officials also seemed to favor protecting typical rather than Indian species of game, possibly because officials were sportsmen as well. Mr. Fitzpatrick wrote to A.C. Duffy, the Assistant Secretary to the Chief Commissioner of the Central Provinces in a letter to the Home Department, that game such as bustard, hares, quail and partridge should be protected. In Punjab, Mr. Cater, a concerned individual, supported preservation for deer.

Game was also on the decline due to the destructive nature of "vermin" such as wild dogs, many of whom attacked game. The government correspondence suggested that a reward of Rs. 30 be implemented so that people would have an incentive to shoot such "vermin" and clear the forests of these predators. To further limit unrestrained shooting, the collector of the Nilgiris proposed that a fee be paid to shoot in reserved 
portions of the forest. Therefore, the implementation of fees helped restrict unregulated shooting in the reserved forests.

A system of licenses was the government's answer to dwindling stock of game. The prices of licenses and the method of applying for licenses differed according to the region. In princely states such as Kashmir, one applied to the resident or the Maharajah for a license. However to shoot in Mudumalai forest or the Nilgiris one had to apply to the collector of the Nilgiris (based on the Nilgiri Game and Fish Preservation Act which included Coimbatore and Malabar part of the Madras Act II of 1879) and pay the Rs.15 associated fee and abide by the laws listed on the license. The licensee had to sign the license to signify that he acknowledged and understood the laws. The only reason a license could be denied was for nonpayment of fees or if the applicant was convicted of a crime against the laws.

Measures to help multiply game were also proposed. The Nilgiri Game Association proposed the introduction of partridges and peafowl in the Nilgiris to repopulate these game birds. This proposal also had a secondary reason as it would allow game association members the opportunity to shoot more game birds. Deer, both female and the young, were not allowed to be killed in the reserved or rented forests of the Nilgiris-Wynaad areas. The collector had the power to close hunting during any time of the year in reserved or rented forests. The fine for non conformance was Rs.200 or one month's jail after conviction by a magistrate.

\section{Successful or Not?}


Game preservation reports even though they are government documents are not very accurate scientifically in terms of the numbers of game as it was based on observing large areas so it was possible to miss some animals. The lack of clear statistics about the numbers of various game made informed, well-reasoned opinions by officials all the more important when it came to arguments for or against game preservation. Captain C.T. Bingham, the Deputy Conservator of Forests of the Western Division wrote that due to the heavy forests in Burma the reproduction of game was not jeopardized. Lots of forest equated automatically to lots of animals regardless of the fact of whether there were actually sufficient game in the forests or not. Many times opinions were formed by hearsay. Captain C.T. Bingham, the Deputy Conservatory of Forests, Henzada, recalls how he heard of venison sold all-year long at bazaars in various towns in 1885 and goes on to say that most hunters consumed game within their families or villages but does not state how he knows this. Rising cultivation at the expense of forest lands led to the decline of jungle fowl and peafowl in places like Burma where large paddy estates arose. However, E.W. Oates, the executive engineer of the Tharrawaddy division who noticed the decline of these birds reasoned that it was due to a lack of forest cover. Similarly, he argued that cotton-tea, comb ducks, and whistling teal were in abundance so no additional legislation to protect this game was necessary. Once again, there was a lack of accurate statistics on the exact number of cotton-tea, comb ducks or whistling teals in the forests.

While game was largely protected, there were still private shoots that were highly unregulated in the maharajah's preserves. Despite game regulation in the $20^{\text {th }}$ century to restrict game bird shooting, private hunts continued and amounted to mass murder of 
game birds and typical English game favorites such as hares. Colonel Lance, Colonel Coke, Lord Leicester, Mr. Rippongale, and Colonel Dailey, all joined to help shoot hares. Anglo-Indian hunters preferred partridges and pheasants over other game birds such as ducks. During three days of hunting at Holkham in 1939, they killed 512 partridges and 399 pheasants. ${ }^{418}$ These numbers are quite high for simply a three-day period thereby depicting the liberal taking of game. Overall, pheasants were killed the most in a single day's shoot, resulting in an average of around 200-300 game birds. On some days hunters killed more than 700 game animals. A lot of it had to do with the skill of the shooters, their interest to kill a particular type of game, and whether or not there were favorable conditions to allow for the shooting.

A great number of game was allowed to be shot by privilege. Arthur Barlow was an AGG or Assistant Governor General and men of his stature often received such preferential treatment. The enthusiasm, excitement, and adrenaline rushes that were associated with shootings led to a frenzy of rapid shots in the air to aim for game birds at such events. In a partridge shoot in Kathiawar in 1934 there were 349 partridges shot along with 116 hares. Arthur Barlow describes the flurry of birds in the following manner "they covered the ground as thick as flies." ${ }^{\text {" } 19}$ He also writes that "I have never seen so many birds" which suggests a multitude of birds and other game clouding the scene. The fracas the year before led to the deaths of six beaters. Many shooters or hunters became so excited with the numerous birds that they ignored or neglected safety

\footnotetext{
${ }^{418}$ Hunting Cards and Licenses. Mss Eur F157/807 British Library.

419 Letter. Arthur Barlow to Daddy and Aunt May. Feb. 18, 1934. Barlow Papers. Center for South Asian Studies. Cambridge University.
} 
measures for the beaters, which indicated a devaluation of the beaters' lives. In 1934 however, none of 600 beaters were affected by random shots.

\section{Conclusions}

The late $19^{\text {th }}$ and $20^{\text {th }}$ centuries saw the rise of game legislation, a fight against poachers and poaching-like activities by the government, and strong efforts by the government to curtail dwindling stocks of game and to stop the extinction of game. Private organizations such as game associations were also involved in tandem with the government to protect game as it was in their interest to still have a supply of animals to shoot. Poachers and similar activities were actively battled and the result led to a decline in the number of poachers. Game continued to decline, however, for a number of reasons that have been articulated by this chapter. Nevertheless, government efforts were largely successful in creating a system of licenses, laws, fees and fines including jail time for not following government regulations of hunting. The government appears to have contributed a great amount of money and resources to actively battling poachers although I have been unable to determine the precise figure. Certain game flourished while others did not. This remained a fact even in the post-colonial period as game continued to decline and poachers continued to poach. The late $19^{\text {th }}$ and $20^{\text {th }}$ centuries nevertheless witnessed significant, crucial changes as the government began to regulate the sport of hunting. 


\section{Conclusion:}

\section{Hunting in the independent South Asian countries}

Shikar did not end with the transfer of power in 1947. Villagers and shikaris continued to hunt with Europeans, although not necessarily the British. Americans generally took up the mantle of the British and became constant hunting companions for Indian hunters. Many hunters like Pir Ali Mohammed Rashdi, Jamshed Butt, and M.A. Ismail continued to hunt into the post-colonial period. These hunters retained from the colonial period the association of hunting with masculinity, the goal of protecting 
villagers from dangerous animals, and a strong sense of etiquette, morality and ethics while operating in a framework of increasing government regulation.

A good example of post-colonial hunting comes from the biography of Dil Das in the book Knowing Dil Das: stories of a Himalayan Hunter. ${ }^{420}$ Dil Das was a low-caste Garwhali peasant who styled himself as a shikari after numerous hunting trips to the jungles with American missionaries and their sons. Shikar remained a manly sport which helped villagers form brotherly bonds with persons outside their social class and caste even in the post-colonial period. Dil Das's caste was Baijgi or basket-weaver. Nevertheless, he found employment as a dudwallah or a man who delivered milk. It was quite uncommon for dudwallahs to be hunters and he did not have any male relatives who were hunters, but Das took a liking to the sport. Das hunted with American men like Ernie Campbell and John Coapman. All these men grew up near a parochial school in the area and shot numerous game such as tiger, pheasant, goorial, kakar and leopard. Dil Das also hunted with Nawabs and other well-esteemed, elite men. The bond between Americans and villagers such as Das was strengthened even with the differences in social classes. Coapman even paid for Das's fare to go hunting in a forest near Delhi. The input of Dil Das when it came to hunting was seen to be valid, strategic and important as he was viewed on equal plains with other Americans.

Das did not know about the different types of guns or permits, but he never believed that this was an impediment to hunting. With age, he acquired hunting knowledge. His expertise of tracking game made him a godsend for local villagers. He

\footnotetext{
420 Joseph S. Alter, Knowing Dil Das Stories of a Himalayan Hunter (Philadelphia: University of Pennsylvania Press, 2000), 67.
} 
learned hunting and other skills associated with the sport by watching other hunters. For example, he learned how to skin a leopard by watching skinners do the skinning. Once he learned it, he got paid 100 rupees per skin for a Nawab he was hunting with. Dil Das had a keen measure of common sense when it came to hunting. In another case, when hunting a tiger, he could tell that the animal was nearby by feeling that its urine was still warm. This practical knowledge was crucial to determining the next move in the hunting plan and helped Das successfully "bag" the animal.

Villagers asked Dil Das to protect them from animals that had been lurking near by their fields. Dil Das was one of the few men in Pathiani, the village that he lived in, who possessed a gun and permit to shoot wild game. Das's manly instinct to protect his fellow villagers was a highly praised trait among the villagers. Das also hunted game birds for villagers. A village man who was quite ill was given a kalij pheasant that was shot by Das at the elderly man's wife's request. She believed that pheasant would give the man strength to overcome his weaknesses and his ailments. Even though hunting served economic needs, for Das hunting was always a leisure sport. Joseph Alter, Dil Das' biographer wrote that Das became enamored [with ] blood sport, and his own story is ironically and tragically constructed in terms of this imperial allegory of power." ${ }^{{ }^{21} 1} \mathrm{An}$ example of his power was his ability to say no to a forest guard who asked him for the head and feet of the goral. Das felt that he was the rightful owner of the goral since he had shot it.

\footnotetext{
${ }^{421}$ Joseph S. Alter, Knowing Dil Das Stories of a Himalayan Hunter (Philadelphia: University of Pennsylvania Press, 2000), 9.
} 
A major difference between Dil Das's hunting method and that of British sportsmen of the $20^{\text {th }}$ century was the fact that Dil Das shot domestic animals as well if they happened to be in sight and the property owner not around. Dil Das happily narrates how he shot a chicken while out hunting because he happened to see it. British sportsmen reserved the rifle for wild game only. The British more often paid servants to buy food and supplies for the hunt. For Das, any animal was fair game for if he had a rifle in hand he had the power to take it.

Shikar remained a sport popular among Europeans and Americans. Geoffrey Ward, an American man and historian, wrote of his childhood in India and one of his highlights was shikar. He writes how he learned to shoot at a young age and hunted several animals including black buck, fox, hare, and owl with a 12 gauge shotgun, which he got from a gun shop owned by Sikhs. ${ }^{422}$ Similar to other Anglo boys residing in India, he also dreamt of killing tigers. He also discusses how indigenous methods were still being pursued in the sport of shikar, although the preeminence of the gun certainly reflected the dominance of the Anglo-Indian hunting tradition. As a little boy, he describes how a village boy caught ducks underwater with a big pot on his head for Rs.5 each.

With the Anglo-Indian hunting tradition firmly in place, the Indians began to take up the old roles of the British as paternal hunters. Colonel Jaipal Singh was another hunter during the post-colonial period. His book entitled Great Hunt includes several

\footnotetext{
${ }^{422}$ Geoffrey C. Ward, Tiger-Wallahs Saving the Greatest of the Great Cats (New Delhi: Oxford University Press, 2000), 26.
} 
pictures of tribals and shikaris as well as animals that he shot. ${ }^{423}$ Singh took over the paternal mantle from the British as he hunted rogue animals that were causing harm or disturbances to villagers. The Colonel included an appended copy of the letter sent to him by the sub-divisional officer of Tripura, Mr. K.P. Chakarabodi, for his hunting efforts. The letter expresses a great sense of gratitude for taking care of the wild elephants and relays a sense of thankfulness on behalf of the people of the district. The collector of Tripura had requested that he go out and shoot the wild elephant.

Even though Singh's book has numerous pictures of animals that he has shot he still felt uneasy about elephant shooting. He writes "I was not very keen on shooting, as the times had changed." ${ }^{24}$ Nevertheless, he still went ahead with the shoot, taking two shikaris- Menu Mian and Jernal his skinner and tanner - along with Colonel Sehgal and three rifles; a .360 No.2, a .315 mauser, and a $.451 / .400$ D.B. Express. From his hunting photographs it is clear that he hunted with other military officials who shot anything from small game birds to panthers. Hunting remained a sport where communal backgrounds were broken down, as was the case with Colonel Singh, who intermingled with Muslims and tribals and often entertained them with dances. The Lieutenant-Colonel also accompanied village boys who shot turtles and game birds.

Just as hunting gave a sense of power and virility to Dil Das, the sport likewise gave these traits to other great Indian hunters. Devipradesh Bandhopadhya writes in Bagha o Baghini that hunting made a man bold, brave, and powerful but hunting also required a considerable amount of strength. Hunting was also a way for lowly men to

${ }^{423}$ Col. Jaipal Singh, Great Hunt (NY: Carlton Press, 1981), 50.

${ }^{424}$ Col. Jaipal Singh, Great Hunt (NY: Carlton Press, 1981), 95. 
associate themselves into the brotherhood of great hunters. Jim Corbett and Kenneth Anderson were always described as great, model hunters that Indians looked up to. Hunting also provided a modest source of income for hunters as well as for poor young men who felled trees for a living. The irony was that hunting could not be practiced in one's old age and consequently many hunters only had the memories of hunting glory that they reveled in during old age. Such was the fate of the great hunter Kali Padanath who lived in poverty after he became too old and weak to hunt. ${ }^{425}$ Bandhopadhya relays the fact that hunters lived a "promise-less" and precarious life, for the bounty of nature varied and the hunter was at the mercy of chance and good fortune.

One of the major constants between the colonial and post-colonial periods was the great tension caused by man-eating tigers and the hunter's determination to eradicate the man-eater. Man-eater tigers and to a lesser extent leopards were a major cause of distress for many villagers who resided in areas where these animals frequented. Countless lives were lost at the hands of man-eaters. According to official records from the West Bengal Forest Department, 30,000 people die annually in the Sunderbans, presumably from man-eating tigers. ${ }^{426}$ Men who made a living in the Sunderbans and other forests collecting honey and wood were especially in danger from tiger attacks. While these men were aware of the possible pitfalls involved with their profession, they needed the income generated from selling forest goods to the forest department to support their families. These men paid Rs. 2 to sell the forest goods they obtained to the forest

\footnotetext{
${ }^{425}$ Devipradesh Bandhopadhya, Bagha O Baghini (Kalakata: Naba Sahitya Prakasa, 1975), 77.

${ }^{426}$ Biswanath Bose, Abhisapta Sunderban (Kalikata: Aruna Prakasani, 1969), 4.
} 
department at a fixed price. The forest department did not pay the market value of the goods and therefore many of these men were susceptible to loan sharks called mahajans. Consequently, the Sunderbans or 'beautiful forest' was ironically a place of grave danger, bloodshed and the place where debt only rose for poor people.

Biswanath Bose, a famous Bengali writer, both in Abhisupta Sunderban and Baghe Manushe takes a very different turn than most conservationists. As a writer he is more concerned with the human experience than that of the tiger. The emotions and feelings aroused within the hunter and his party take precedence over that of the death of the tiger, for the tiger is of course a man-eater, subject to trickery and deception. Bose's view of tigers is similar to those of many Indian hunters who detested the chalak or smart, cunning qualities of the man-eating tigers. In fact, in Baghe Manushe, Bose describes the hunter's triumph over the man-eater of the Sunderbans. The hunter, Gopindra Krishna Bagchi, is described as a hero for being brave in the midst of four or five other British friends, who refused to hunt the dangerous Royal Bengal tiger in the Sunderbans. Gopindra took his friends in a small boat down the Matla River for hunting. His keen sense of knowledge about shikar helped him traverse through the numerous tributaries, canals and tunnels in search of the man-eating tiger. Gopindra knew how to study footprints in wet clay to understand the present whereabouts of the tiger and understood the deceptive ways of the tiger who sought to hide from the hunter only to come back at the spur of the moment and attack the hunter. He also knew that many hunters became awed and speechless by the tiger's roar and presence and failed to kill the 
tiger. Gopindra was very shrewd in that he kept his eye on the prize (the 9 foot tiger) and made sure he successfully killed it and did not become it's victim. According to Bose, the tiger only wanted one thing - human flesh - and when the tiger encountered the hunter, both began shikar. ${ }^{427}$

\section{Post-colonial Conservation}

Post-colonial conservation owed a great deal to the conservation efforts that the $R a j$ had implemented beginning at the turn of the century. Forest officials were instrumental in the drawing up of game sanctuaries and parks. Game preservation societies also became fashionable and in vogue during the late Raj. Olive Symthies writes that her husband, Evelyn Smythies, the Chief Conservator of Forests (Kumaon), had demarcated Kumaon and the boundaries of Corbett National Park and also drafted an act for the Sanctuary's Legislature. Hunters such as Jim Corbett were also instrumental in the forging of conservation policies in India. The changing values and mores of British sportsmen during the late $R a j$ also contributed to a consensus on game preservation. Hunters such as Jim Corbett and their conservationist tendencies would have a great role in building a new generation of Indian activistconservationists. The policies promoted during the British period were more or less followed by the independent Indian nation. As Valmik Thapar writes, R.W. Burton's paper the "Preservation of Indian Wildlife" from the colonial period was used as a stepping stone by M.D. Chaturvedi, Inspector-General of Forests in the post-colonial

\footnotetext{
${ }^{427}$ Biswanath Bose, Baghe Manushe (Kalikata: Aruna Prakasani, 1968), 1-11.
} 
period. ${ }^{428}$ Thapar believes that the roots of environmentalism stem from British colonial officials viewpoints, rather than Michael Lewis' interpretation of the ecological awareness a product of an American inspired vision. Non-governmental organizations such as the WWF (World Wildlife Fund) were also active in facilitating conservation efforts in the subcontinent.

A major task of organizations such as the WWF was not only to protect wildlife but also to collect information about environmental protection policies. The World Wildlife Fund's India branch established a data center in order to compile information on conservation policies that integrated knowledge by academic research scholars, forestry departments, wildlife wardens and research experts on environmental studies. ${ }^{429}$

In 1952, the Indian Board for Wildlife was established in order to prevent further declines in the nation's wildlife stock. The Wildlife Act was passed in 1982 to further the goals proposed by the Board of Wildlife. India also currently has 53 national parks and 247 wildlife parks. In addition to the well-known Project Tiger, the Crocodile Project was also launched in order to protect dwindling numbers of endangered crocodiles.

The Indian government under Indira Gandhi enacted the Forest Act of 1980, which restricted the use of forest lands and prevented the felling of trees. Maintaining the forests was intricately connected to the preservation of the habitat for wildlife. Without a balanced ecosystem with sufficient forests, the bio-diversity present among the wildlife

\footnotetext{
${ }^{428}$ Valmik Thapar, The Last Tiger: Struggling for Survival (Oxford: Oxford University Press, 2006), 34-38.

429 J.W. Thorsell, Ed. Conserving Asia's Natural Heritage The Planning and Management of Protected Areas in the Indomalayan Realm Proceedings of the $25^{\text {th }}$ Working Session of IUCN's Commission on National Parks and Protected Areas (Cambridge: IUCN , 1985), 9.
} 
species would inevitably decline. The Forest Act represented the triumph of nature over the needs of agriculture and urbanization and the increasingly metropolitan quality of life. The ecological demands of the forests and wetlands were thus at stake if not under government protection.

While India has moved furthest in conservation efforts, the subcontinent's neighbors have followed in India's footsteps. Bangladesh enacted a wildlife preservation act in 1973 intended to protect a wide range of species. The act also established three national parks and six wildlife sanctuaries.

In the 1970s, Nepal began its conservation efforts to protect the nation's wild animals. King Mahendra established national parks and reserves. In 1985 Nepal had four wildlife reserves and six national parks and surprisingly still maintained one hunting reserve. Game legislation directly affected the subsistence of tribes such as the Santhals who used bows and arrows to shoot their game. Just as in India, problems emerged in some national parks. In Sagarmatha National Park, for example, the Director-General of the Department of National Parks and Wildlife Conservation of Nepal noted "It has been necessary to cull selected dangerous animals such as 'man-eating' tigers." ${ }^{\text {"430 }}$ Removal of certain animals meant that they were not protected from people or poachers and selective conservation occurred instead of a more holistic approach that included all animals. The international network of zoos also had a vested interest in promoting the reproduction and breeding of endangered species. For example, the Frankfurt Zoological Society helped

\footnotetext{
${ }^{430}$ Ibid, 79.
} 
develop a breeding station in Chitwan National Park with the end-goal of multiplying the number of gharial or crocodiles.

The Pakistani government also created a system of national parks and wildlife sanctuaries along the same lines as Nepal. Pakistan also possesses game reserves and private game reserves. The provincial government of Punjab, for example, also created the Punjab Wildlife Management Board. Game reserves numbered 73 in 1985. Game reserves were locations where shooting was permitted on the basis of a system of licenses that allowed hunters to shoot during specific seasons. These game reserves included such animals as partridges, bustards sand grouse, chikara and hog-deer. As of 1955, there were five national parks in Pakistan. They include: Margara Hills, Khunjerab, Hazarganji, Chiltan, Kirthar and Labohanra.

The Corbett Action Plan was similarly proposed at the session in Corbett National Park where a list of forests, national parks or reserves were identified as needing urgent action in India. The paper also emphasized high notes of successful conservation. Examples on the list included the posting of an electric fence to prevent deer from damaging local villagers crop at Dudhwa National Park. This was a good solution that appeased villagers and persuaded them to be content with the presence of the park.

The task force also recommended the incorporation of environmental studies with a focus on conservation to be implemented into the curriculums of school-age children, thereby helping them learn the importance of conserving nature - both its forests and wildlife. ${ }^{431}$ India led the way in Asia in developing educational curricula at higher

\footnotetext{
${ }^{431}$ Ibid, 196.
} 
institutions of learning for wildlife conservation issues. The wildlife courses institute of India located in Dehra Dun served as one such model.

A prominent conservationist was "Billy" Arjan Singh. Arjan Singh came from a family that actively engaged in shikar. Singh had a change of heart and writes that though he participated in hunting with "enthusiasm [... he] now feel[s] thoroughly ashamed." 432 Singh shows that tigers are still in danger in India. Singh was one of the main forces behind the establishment of Dudhwa National Park. Unlike traditional conservationists who only lobbied for the creation of national parks, Singh also created and ran what he called Tiger Haven, which was essentially a home for tigers in Uttar Pradesh. Both $A$ tiger 's story and Tiger! Tiger! describe how he raised a tiger at Tiger Haven and then reintroduced Tara (the name of his tiger) back into the wild. Indira Gandhi presented two leopard cubs to Billy Singh to rear. He raised these leopards in a nearby haven that he owned and relays his experience with these animals. Singh took an activist stance to protect these animals because he felt that the government was not doing enough to protect them.

Another conservationist was Fateh Singh Rathore from Rajasthan. Rathore was instrumental in formulating and supporting tiger conservation policies in Ranthambhore. Diana Wordsworth, a British lady introduced him to the importance of conservation and encouraged him to protect Ranthambore's forests. Rathore's dedication to conservation made him the target of brute attacks because of his views. In 1981, Rathore was clubbed

\footnotetext{
${ }^{432}$ Arjan Singh, Tiger! Tiger! (London: Trinity Press, 1984), 31.
} 
by around 50 angry villagers. ${ }^{433}$ The hardships that many of these conservationists faced recall the uneasiness during the colonial period between agriculturalists and conservationists.

Even with large scale conservation projects in place, the depredations caused by tigers did not end. As J.S. Carrington Turner writes, depredation in Kumaon continued well into the post-colonial period, with reports of man-eating tigers continuing at least until 1955 . Women who had to go into the forest particularly to obtain oak leaves (for fodder) had no choice but to continue gathering leaves, and consequently took a significant risk of tiger attacks. Arjan Singh notes how by 1984 , 110 people had been killed by man-eating tigers in Kheri. ${ }^{434}$ Singh attributes the making of a man-eater to the expansion of settlement and the lack of alternative prey (which is strikingly similar to Jim Corbett's deduction). Death or harm inflicted onto tigers did not stop even in the midst of an era of conservation. In 1997, Singh writes that tigers were poisoned in the Dudhwa and Corbett reserves. ${ }^{435}$ Muslims, low-caste and tribal Hindus continued their poaching efforts. Tiger skins were also smuggled to Nepal and Tibet as outfits for special festivals.

Just as Nehru had implemented five-year plans for economic progress and advancement, successive administrations implemented their own five year programs when it came to conservation of India's diverse wildlife. While high profile projects such as Project Tiger were implemented in India, conservation measures initiated during the

\footnotetext{
${ }^{433}$ Geoffrey C. Ward, Tiger-Wallahs Saving the Greatest of the Great Cats (New Delhi: Oxford University Press, 2000), 135.

${ }^{434}$ Arjan Singh, A Tiger's Story (New Delhi: Tara Press, 2005), 147.

${ }^{435}$ Ibid, 252.
} 
colonial period were not repudiated, but in fact they were continued and extended. H.S Panwar, the Director of Project Tiger of the Department of Forests and Wildlife of India writes that the seventh five year plan of 1985-86 proposed by the National Wildlife Action Plan originally recommended by a task force of the Indian Board of Wildlife emphasized cooperation with the locals by giving preference to local villagers in wildlife reserves. The on-the-job experience would help villagers or tribals understand the need for the conservationist policies hands on and perhaps even adopt a conservationist mindset. Wildlife tourism was another way to attract the general public to understand the goals of wildlife parks and their fundamental perception.

Upon Geoffrey Ward's return to India in 1985, he writes of the mixed success of Sariska forest as a marker of the overall success of conservation policies implemented by the government. Ward writes that there were scarcely any partridges and black buck, as they were now replaced by wheat and mustard fields. However, Sariska had a flowering of other game. He writes "there had been no chital at all when I hunted at Sariska. Now they seemed to be everywhere. Some 6,000 of them, if the field director's census figures were correct." ${ }^{" 436}$ Numbers of certain game flourished at the expense of other game. Valmik Thapar also discusses the failure of conservation at the national level as Sariska did not have any tigers in it by the $21^{\text {st }}$ century. The working papers of the $25^{\text {th }}$ working session of The International Union for Conservation of Nature and Natural Resources (IUCN) Commission on Natural Parks and Protection areas, held by the staff of the

\footnotetext{
${ }^{436}$ Ward, Tiger-Wallahs, 17.
} 
Corbett National Park India from February $4^{\text {th }}-8^{\text {th }}, 1985$, shows that great progress has been made in the Indo Malayan realm for conservation of various species such as tiger. A major impediment to the goals of conservation was the fact that hunting was still possible, at a price. The Prince of Jodhpur told Geoffrey Ward that if he hunted, the prince could have the skins and heads prepared for the party and the trophies could be smuggled out of the country. ${ }^{437}$ Payment of five hundred dollars plus imported liquor would cover the costs necessary to bribe local villagers for their silence and customs officials who searched for illicit articles. Ward was given the choice to shoot whatever he pleased.

Among the impediments to conservation efforts was the prevailing mentality of most farming villagers. Villagers feared wild animals and believed that all tigers should be killed because they are a danger to livestock, crops and humans. The idea of conservation was not imbued in most villager's minds as their economic and practical needs figured first. The large population present in India often in dense settlements also produced conflicting demands to that of the needs of wildlife. Conservation, while it is often touted as a miracle, caused immense tensions by agriculturists due to large-scale projects that were intruding into the former's space. For example, the villages of Dhara and Jhirna on the outskirts of Rajaji National Park were literally moved in order to accommodate the needs of conservationist planners.

During the independent period in India, the government continued the policy of compensation that was typically the main stay of the British sportsman-sahibs, who

${ }^{437}$ Ibid, 32. 
offered compensation for the death of livestock or humans after bagging the tigers.

Similarly, the forest department paid 10,000 rupees for an adult, 5000 for a child, 3000 for a buffalo and 800 for a cow in Govindnagar. 438

The Forest Department was in debt to conservationists since they used their expertise for coming up with official reports. For example, Valmik Thapar undertook a census for tigers. Thapar also is the founder of Tiger Link, a quarterly newsletter of information on tigers in each of the parks or reserves in India. ${ }^{439}$ Conservationists like Valmuk Thapar also came up with a lot of solutions on how to solve the impending crisis of the possible extinction of tigers. They were also out-spoken critics of the government's failures in managing select forest like Sariska International. NGOS were suggested as a possible solution by Valmik Thapur along with research on protected areas and stipends for persons interested in protecting tigers, thus giving them an incentive to save wildlife. ${ }^{440}$ Thapar believed that one of the major impediments to conservation success was the lack of a wildlife department as wildlife policies and acts were administratively under the Forest Department. Valmir Thapar stated that annual tiger counts were often skewed higher so that the project would be deemed a success. Michael Lewis also states that there were a lack of forest officers that were trained in wildlife management and hardly any research posts to support the growth of the tiger population and no understanding of tiger issues. Overall, Project Tiger was only a minor success.

Conservationists were not the only persons interested in wildlife and hunting.

\footnotetext{
${ }^{438}$ Ibid, 191.

439 Ibid, 194.

${ }^{440}$ Valmik Thapar, The Last Tiger Struggling for Survival (New Delhi: Oxford University Press, 2006), 120-121.
} 
Ardendhu Datta was a wildlife journalist who helped bring awareness to Indians and Bangladeshis of wildlife in his book Sikara Jangala. He was also an avid painter of wildlife. A testament to his dedication to wildlife comes in the form of a certificate, which was bestowed upon him by Lady Linlithgow. ${ }^{441}$ In order to accurately paint wildlife, he spent numerous nights in the forest with a wide variety of hunters. Hunters remained an important medium in independent India for both conservationists, wildlife journalists, forest departments and various NGOs (non-governmental organizations).

\section{Concluding Remarks}

As Ina Shumshere Rana and Mani Dixit state in Those Were the Days hunting was technically over for "protected species." ${ }^{\text {"42 }}$ Even though the authors were referring to Nepal in the 1970s, the tide had turned against un-restrained hunting in the Indian subcontinent as the government clamped down on poaching and hunting without a license or permit during the mid-20 $0^{\text {th }}$ century. This reflected a continuation and intensification of conservation measures from the colonial period, which as Joseph Hodge has emphasized led to a growth in developing countries' state bureaucracies. This South Asian pattern resembled the growth of bureaucracy and restrictions that occurred in early modern Britain, but with the difference being that international conservationists became involved in preservation efforts as an additional entity overseeing wildlife conservation. In other settler colonies like East Africa, Africans continued to be denounced as poachers and the

\footnotetext{
${ }^{441}$ Ardhendu Datta, Sikara Jarnala (Kalikata: Purna Prakasana, 1977), Preface.

${ }^{442}$ Ina Shumshere Rana, Those were the days (Kathmandu: Sharda Prakashan Griha, 1977), 6.
} 
only legitimate hunters remained the British sportsmen. While conservation efforts that began during the colonial period may be deemed successful in that these animals still exist, there are some animals that were indiscriminately shot like gharial or muggers (crocodiles) that are still endangered species today. The situation in Britain in the $20^{\text {th }}$ century also saw the rise of conservation efforts especially for game birds in the hands of gamekeepers. Therefore, the trend towards conservation was a direct result of the activity of hunting. In India the government (both colonial and post-colonial), international conservationists and domestic activists all championed game preservation efforts.

As Emma Griffin has already emphasized, hunting created numerous social tensions among government and agriculturists, animals and agriculturalists, poachers and sportsmen and conservationists, both international and domestic, and government. By the $20^{\text {th }}$ century, there was a steady rise of the sahib's hunting values and ethos, which led the British to condemn the traditional local practices of ordinary Indians as poaching. Yet this is how tribal hunters lived for centuries before the arrival of the British. The sahib's hunting ethos in a nutshell was a sense of restraint, the use of a gun, and reliance on a shikari. All of these components marked a tendency to define sport as a gentlemanly, refined activity. Hunting was a sport that built and outwardly reflected the character of the sportsman or sportswoman who did not engage in excessive shooting of wild animals, did not indulge in inflicting pain on the animal by using unconventional or nontraditional British methods of hunting reminiscent of the poacher, and most of all relied on a shikari as hunting etiquette commonly recommended a team effort for hunting. The 
British concern for the animals' suffering could very well conceal a more self-interested desire to obtain all hunting opportunities for themselves.

Memsahibs and respectable Indians were privy to participate in shikar provided that they emulated the ideals of the sahibs. Most memsahibs and Indians articulated these values in their hunting styles. These styles derived from the blending of British and Indian hunting traditions. Most British hunters did not follow the unrestricted shooting or “Oriental" excess associated with the maharajas, but many high-level British officials and certain British individuals that accompanied maharajas often hunted in excess at such opportunities. The conservationist ethos that appeared in the late nineteenth century British hunting traditions conformed to the Indian environment and did not depreciate the honor and prestige of the gentlemanly sportsman. As Steven Patterson aptly states "the exhibition of mastery, a behavior that augmented honor was also central in this ideological system and one could never hope to rule others while lacking self control."443 Not everyone subscribed to the Anglo-Indian hunting tradition as records of poachers are found well into the $21^{\text {st }}$ century. Both colonial and independent governments have restricted their activities and forced many to change their livelihoods. It is also difficult to know exactly how much game was decimated at the hands of villagers who used guns to protect their crops or tribals who continued hunting for subsistence in spite of the government's oversight on India's forests. Superstitious demand for items like tiger fat and the luxury demand for ivory have perpectuated poaching of tigers and elephants.

\footnotetext{
${ }^{443}$ Steven Patterson, The Cult of Imperial Honor in British India (New York: Palgrave Macmillan, 2009), 211.
} 
The sahib's and by extension, the memsahib's and babu's hunting ethos was congruent with a belief in the superiority of British ways and values and reflected the character of the gentlemanly rulers and their collaborators the babus, who upheld the same values. The rise of the hunter over the depredations of Indian wildlife symbolized among other things the essence of imperialism. As Alice Conklin states so succinctly "to be civilized was to be free from specific forms of tyranny: the tyranny of the elements over man, of disease over health, of instinct over reason, of ignorance over knowledge and of despotism over liberty." ${ }^{244}$ The hunting code as placated by the British had Indians who emulated their hunting code, not only for the good of the environment but also for India's movement towards progress.

In the $18^{\text {th }}$ century, the British encounter with hunting in India began with the British, as the paramount rulers, forging an alliance with Indian maharajas and Nawabs in an attempt to construct and delineate hunting etiquette, ecological awareness and the tradition of the gentlemanly sportsmen. By the $19^{\text {th }}$ century in colonial India there appear to be a multitude of reasons why British sportsmen hunted, including imperialism, paternalism, boredom, loneliness, the increasing attraction to the popularity of the sport and the flaunting of masculine prowess. Nevertheless, British sportsmen were never independent masculine beings, as they depended on Indians, whether they were maharajas who hosted and paid for hunting events, shikaris who guided and tracked game or coolies who carried their luggage around the subcontinent. Despite their dependence on Indians, which was not emphasized in their masculine dialogue, the

\footnotetext{
${ }^{444}$ Alice Conklin, ed. European Imperialism (Boston: Houghton Mifflin, 1999), 6.
} 
differentiation of Indians was a constant both in the $19^{\text {th }}$ and $20^{\text {th }}$ century that emphasized the British construction of superiority in the hunting field. It was also central to the development of the regal or elite hunt, which emphasized grandeur, proper etiquette and a nascent ecological awareness.

The $20^{\text {th }}$ century saw the continuation of the same reasons for hunting and the same constructions of difference between the British and the Indians in an attempt to delineate British superiority, but it also led to the development of new technology and change with increasing methods of artificiality introduced into hunting techniques, hunting solely for protection with a heightened paternalistic fervor, and a much greater sense of restraint and environmental concerns. The $20^{\text {th }}$ century also saw the melding of British and Indian traditions of hunting as British sportsmen began emulating maharajahs and their hospitality and regal hunts with viceroys such as Lord Louis Mountbatten, Lord Hardinge, and Lord Curzon with his famous picture of his foot on the tiger. The union between the princely elite and the British helped legitimize British rule and display their power over the animals of the subcontinent. The late $19^{\text {th }}$ and $20^{\text {th }}$ centuries also witnessed the rise of a more intrusive $R a j$ with a flurry of government acts, laws, rulings, debates and a system of licenses to regulate hunting and to eradicate the poacher and poaching-like activities. The government's fight against the poacher is reminiscent of the early modern and modern campaign to suppress and discredit poaching and workingclass hunting traditions in Britain itself.

As in Britain, British India saw the increasing presence of women in the hunting arena. Therefore, hunting was not just about masculinity, but many women enjoyed the 
sport either as spectators or actual participants. Women took on typical masculine activities like hunting in order to protect villagers, to have adventure and excitement, to acquire trophies, for posterity, to enjoy the wilderness, accompany their husbands, and to meet men. Women were also fairly bigoted in many of their attitudes or actions towards Indians in the hunting arena, yet there were also women who sought to sincerely help natives. Many women's accounts debate the morality of hunting, which was debated in Britain in such organizations such as the RSPCA and among Puritan circles. The introduction of emotion was one of the main differences between female and male hunting accounts. Women in the $19^{\text {th }}$ and $20^{\text {th }}$ centuries condemned and worked to suppress both poaching-like activities and the "excess" of Indian shikaris similar to British sportsmen.

Lastly, the rise of the Anglo-Indian hunting tradition flourished and remained intact even in the post-colonial period. The sahib and by extension the memsahib's tradition of hunting reigned supreme and the wrath of the government as well as of other Indian sportsmen was against the poacher and poaching-like activities. The conservationist ethos that appeared in the late nineteenth century and rose to dominance in the $20^{\text {th }}$ century marked the power of the British government over suppressing corrupt native poaching traditions. Conservation also marked a major shift in British attitudes as hunting for sport became a gentlemanly pursuit among British sportsmen who viewed themselves as legitimate hunters over the traditional Indian shikari who was classed as un-ecologically aware of the importance of preservation. 


\section{Bibliography}

Archival Materials/Special Collections

British Library

Bengal Forest Department Annual Report on Game Preservation 1935/36-1938-1939. IOR/V/24/1701. British Library.

Nagpur Hunt Club. Mss Eur A225. British Library.

Hunting Cards and Licenses. Mss Eur F157/807 British Library

Mabel Camroux Papers British Library. Mss Eur Photo Eur 170

Game Laws. British Library. IOR: R/20/A/2901 File No. 292/1.

The Madras Game \& Fish Preservation Bill British Library IOR/L/PJ/6/357 File 1912.

Bombay Presidency; report on the extermination of wild animals and venomous snakes

during 1904 British Library IOR/L/PJ/6/723, File 1484

Hunting Gharial (crocodile) British Library MSS Eur D 1233/31.

House of Commons Question on the Indiscriminate offer of rewards for the destruction of

Tigers, 10 July 1906. British Library. IOR/L/PJ/6/769 File 2067.

Mackenzie, Malcolm Ayers. Mss Eur D989. British Library

B199/39 Protection of Wildlife in Burma, protection of Thiamin and Giant Panda IOR/M/

2/1588 17 Nov 1938-May 1941 British Library

The Nawab's Request for Permission to go for a Tiger Shoot in the Kurnool District. No.

CBS. 17-46. Mysore Residency. Bangalore. British Library. IOR/R/2/Box56/588 1946

Question of Preservation of game birds and animals in India. 2 Nov 1886. IOR/PJ/6/189

File 1906

House of Commons question regarding damage to crops in India by wild animals 27 Mar 1907 British Library IOR/L/PJ/6/802, File 882

Papers of Maj Leonard Mourant Handley British Library MSS Eur E399

Malabari, Behramji, The Indian Eye on English Life or Rambles of a Pilgrim Reformer.

(Bombay: Apollo Printing Press, 1895) British Library1889-1895 10349.dd8

Ouvry, M.H, A Lady's Diary Before and During the Indian Mutiny (Lymington: 1872)

British Library, 1854-1892 T36871

Center for South Asian Studies, Cambridge University

E. Barrett Papers. Center for South Asian Studies, Cambridge University Scott, Lady Beatrix Papers. "Tiger Shoot at Goalpara." Box 1-6: 97. Center of South Asian Studies. Cambridge University. 
Barlow Papers. Center for South Asian Studies. Cambridge University.

Showers Family Papers, Center for South Asian Studies. Cambridge University

Stokes Papers Center for South Asian Studies. Cambridge University

Blackwood Papers Center for South Asian Studies. Cambridge University

Stubbs Papers Center for South Asian Studies. Cambridge University

Letter.

Bancroft Library, University of California, Berkeley

FWF Fletcher to Charles Kofoid. 18 ${ }^{\text {th }}$ May 1916. Charles Atwood Kofoid

Correspondence. Banc MSS 82/39cz UC Berkeley Bancroft Library.

Letter. Stella Benson. Jan 26 $6^{\text {th }}$ 1921. Stella Benson Letters to Laura Hutton Banc MSS

2004/128cz UC Berkeley Bancroft Library.

Art:

Ceremonial Cover with Hunting Scene. $19^{\text {th }}$ century. Philadelphia Museum of Art. Mughal Hunting Carpet. Lahore. 1595. Fine Arts Museum, Boston, MA.

Untitled, pigsticking. 1650. Berkeley Art Museum/Pacific Film Archive.

Select Reviews and Spirit of Foreign Magazines (1809-1811)

The Atheneum; or Spirit of the English Magazines (1817-1833)

The Albion, A Journal of News, Politics, and Literature (1822-1876)

Spirit of the Times (1831-1832)

Dwights American Magazine, and Family Newspaper for the Diffusion of Useful

Knowledge

Spirit of the Times; A Chronicle of the Turf, Agriculture, Field Sports (1831-1832)

The Museum of Foreign Literature, Science, and Art (1822-1842)

American Turf Register and Sporting Magazine.

Outlook (1893-1924)

The Youth's Companion (1827-1929)

Forest and Stream: A Journal of Outdoor Life, Travel, Nature Study, Shooting

Outing, an Illustrated Monthly Magazine of Recreation(1885-1906)

Current Literature (1888-1912)

The Friend; a Religious and Literary Journal (1827-1906)

Frank Leslie's Popular Monthly (1876-1904)

Appletons' Journal of Literature, Science and Art(1869-1876)

Ballou's Pictorial Drawing Room Companion (1855-1859)

Flag of Our Union (1854-1870)

Saturday Evening Post (1839-1885)

New Sporting Magazine

London Journal 
Reynolds Miscellany of Romance,general literature, science, and art

Saturday Magazine

Monthly Review

Fraser's Magazine

Chambers Edinburgh Journal

Critic

Blackwood'sBlackwood's Edinburgh Magazine

Badminton Magazine of Sports \& Pastimes

English Illustrated Magazine

Calcutta Review

Royal Magazine

Wide World Magazine; an illustrated monthly of true narrative, adventure, travel, customs, and sport

Scribner's Magazine

Eclectic Magazine

Lady's Magazine

Cosmopolitan, a Monthly-Illustrated Magazine

Harper's New Monthly Magazine

Pearson's Magazine

Tinsley's Magazine

Chataquan

Cornhill Magazine

New Sporting Magazine

Edinburgh Magazine, or Literary Miscellany

The Critical Review, or Annals of Literature

Town and Country Magazine

Badminton Magazine

Newspapers:

News-letters, 1767-1799 (Nawab Mir Nizam Ali Khan's reign). Ed. Yusuf Hussain. (Hyderabad: Central Records Office, 1955).

The Times

Primary Sources:

Aflalo, Frederick George. The sportsman's book for India. London: H. Marshall and Son, 1904.

Ajax. 'Good hunting!'; or, What to do on shikar and how to do it. Calcutta: Thacker Spink \& Co., 1913. 
Allen, Charles and Sharada Dwivedi. Lives of Indian Princes. London: Century Publication Associated with Taj Hotel Group, 1984.

Alter, Joseph. Knowing Dil Das Stories of a Himalayan Hunter. Philadelphia: University of Pennsylvania Press, 2000.

Anon. A new hunting song, made on a fox chase. London: 1750.

Anon. Princely Diversion, or the Jovial Hunting Match.

Anon. The famous and renowned History of the Memorable but Unhappy Hunting on Chevy Chase by the River Tweed in Scotland. London: 1700.

Anon. The life of John Metcalfe commonly called Blind Jack of Knaresborough. With many entertaining anecdotes of his exploits in hunting...York: E.R. Peck, 1795.

Anonymous. Timely hints to amateur shikaries. Madras: Higginbotham \& Co., 1909.

Apponyi, Henrik, Count. My big-game hunting diary from India and the Himalayas. London: Selwyn \& Blount, 1937.

Babur Emperor. Babur-nama in English. Translated by Annette Susannah Beveridge. Britain: Stephen Austin and Sons Ltd., 1969.

Baden-Powell of Gilwell, Robert Stephenson Smyth Baden-Powell, Baron. Memories of India, recollections of soldiering, and sport. Philadelphia: D. McKay, 1915.

Baillie, W. W., Mrs. Days and nights of shikar. London: J. Lane Co., 1921.

Baker, Edward B. Sport in Bengal: and how, when and where to seek it. London: Ledger Smith \& Co., 1887.

Balfour, Edward Ed. Cyclopedia of India and of Eastern and Southern Asia, vol 5. Madras: Lawrence and Adelphi Presses, 1873.

Bandhopadhya, Devipradesh. Bagha O Baghini. Kalakata: Naba Sahitya Prakasa, 1975,

Beckford, Peter. Thoughts on Hunting London: D. Bremner, 1798.

Best, James W. Forest Life in India. London: J. Murray, 1935. 
Bhupa, Nripendra Naryana Maharajah of Cooch Behar. Thirty-seven years of big game shooting in Cooch Behar, the Duars and Assam, A rough diary. London: R. Ward, 1908.

Bore, Big. Guide to shikar on the Nilgiris. 1924.

Bose, Biswanath. Abhisapta Sunderban. Kalikata: Aruna Prakasani, 1969.

Bose, Biswanath. Baghe Manushe. Kalikata: Aruna Prakasani, 1968.

Brinckman, Arthur. Rifle in Cashmere: a narrative of shooting expeditions in Ladak, Cashmere, Punjaub, etc., with advice on traveling, shooting and stalking: to which are added notes on army reform and Indian politics. London: Smith, Elder, Co., 1862.

Buck, William. Ramayana. Delhi: Motilal Banarsidass, 2000.

Burke, W.S. The Indian Field shikar book. Calcutta, 1908.

Burton, Richard F. Goa and the blue mountains, or, Six months of leave. Berkeley: University of California Press, 1992.

Burton, Richard Watkins. Tigers of the Raj : pages from the Shikar diaries, 1894-1949, of Colonel Burton, sportsman and conservationist. Gloucester: Sutton,1987.

Butler, Alfred Joshua. Sport in Classic Times. London: E. Benn Limited, 1930.

Butt, Jamshed. Shikar. London: Robert Hale, 1968.

By a late customs officer. Past Days in India; or, sporting reminscences of the valley of Soane and the basin of Singrowlee. London: Chapman \& Hall, 1874.

Campbell, Walter. The old forest ranger, or, Wild sports in India on the Nielgherry Hills, in the jungles and on the plains. New York: Stringer \& Townsend, 1853.

Christopher, Sydney Albert. Big game shooting in Lower Burma. Rangoon: Burma Pictorial Press, 1916.

Corbett, Jim. Man-Eaters of Kumaon. Bombay: Oxford University Press, 1946.

Cox, Harding Edward de Fonblanque. Chasing and Racing; some sporting reminiscences. New York: Dutton, 1922, 
Cox, Nicholas. The Gentleman's Recreation in Four Parts, viz. hunting, hawking, fowling, fishing... London: J. Dawks, 1697.

Crespigny, de Champion Claude, Sir. Forty years of a sportsman's life: with two additional chapters covering the period 1910-1924. London: Mills and Boon Ltd., 1925.

Crook, Joseph Mordaunt. The rise of the nouveaux riches: styles and status in Victorian and Edwardian architecture. London: John Murray, 1999,

Cuming, Edward William Dirom. British sport past and present. London: Hodder and Stoughton, 1909.

Curzon, Mary. Lady Curzon's India : letters of a vicereine ed. John Bradley London: Weidenfeld \& Nicolson, 1985.

Datta, Ardhendu. Sikara Jarnala. Kalikata: Purna Prakasana, 1977.

Deva, Rudra Raja of Kumaon. Syanika sastra: or a book on hawking. Calcutta: Royal Asiatic Society, 1910.

Digby, Davies. Tiger slayer by order. London: Chapman \& Hall, 1915.

Douglas, Hamilton. Records of sport in southern India, chiefly on the Annamullay, Nielgherry and Pulney mountains. London: R.H. Porter, 1892.

Dunbar Brander, A. A. (Archibald Alexander). Wild animals in Central India. London: E. Arnold \& Co., 1923.

Eardley-Wilmot, S., Sir. Forest life and sport in India. London: E. Arnold publisher for H.M. India Office, 1910.

Eastwick, Edward Backhouse. Murray's Handbook for Travellers in India, Burma and Ceylon, $15^{\text {th }}$ edition. Calcutta: Thacker, Spink \& Co., 1938.

Eden, Emily. Up the Country: letters written to her sister from the upper provinces of India. London: Curzon Press, 1978.

Eden, Fanny. Tigers, durbars, and Kings: Fanny Eden's Indian Journals, 1837-1838 London: Murray, 1988.

Elliott, John Malsbury Kirby. Fifty Years Fox Hunting with the Grafton and other packs. London: Horace Cox, 1900, 
Elmhirst, Edward Pennell. The best of fun, 1891-1897. London: Chatto and Windus, 1903.

Ellis, Maudie. The Squire of Bentley (Mrs Cheape): Memory's Milestones in the Life of a Great Sportswoman. Edinburgh: William Blackwood and Sons, Ltd., 1926.

Ellison, Bernard. H.R.H. the Prince of Wales's sport in India. London: W. Heinemann, Ltd., 1925.

Ettan, T.M. Oru sikkariy ute Smarayankal. Kottayam: Sahityapravarttaka Sahakaran asangham, 1971.

Fielding, Henry. Tom Jones. London: 1861

Fife-Cookson, John C. Tiger-shooting in the Doon and Ulwar : with life in India. London: Chapman \& Hall, Ltd., 1887.

Gardiner, John Smallman. The art and pleasures of hare-hunting in six letters to a person of quality. London: R. Griffiths, 1750.

Fletcher, F. W. F. Sport on the Nilgiris and in Wynaad. London: MacMillan, 1911.

Gardner, Nora Beatrice. Rifle and spear with the Rajpoots: being the narrative of a winter's travel and sport in northern India, by Mrs. Alan Gardner. Illustrated from photographs and sketches by the author and two drawings by F.H. Townsend. London: Chatto \& Windus, 1895.

Gent, A.S. The Gentleman's Compleat Jockey: with the Perfect Horseman, and Experience Farrier. London: 1700.

Gentleman. Sportsman's Companion or an Essay on Shooting by a Gentleman who has made Shooting his favorite amusement upwards of 26 Years in Great Britain, Ireland, and North America. New York: 1783.

Glasfurd, Alexander. Musings of an old shikari; reflections on life and sport in jungle India. Delhi: Natraj Publishers, 2001.

Gough, John. The hare, or hunting incompatible with humanity written as a stimulus to youth towards proper treatment of Animals. London: 1799.

Grant, Claude. The shikari a hunter's guide. Westminister: 1914.

Greville, Violet Lady, Ladies in the Field. New York: D. Appleton \& Co., 1894. 
Kildeer. Timely hints to amateur shikaries. Madras: Higginbotham \& Co., 1909

Kipling, Rudyard. The Jungle Book. New York: The Century Co., 1894.

Kaye, M.M. Golden Afternoon. New York: St. Martin’s Press, 1998.

Kendrick W.S. A new fox-hunting song, composed by W.S. Kendrick, and J. Burtell; The chace run by the Cleveland Fox Hounds on Saturday the 29th of January, 1785. London: S.N., 1785 .

Hardy, Henry Frederick Hamilton. English Sport. London: Country Life, 1932.

Haughton, H. L. (Henry Lawrence). Sport \& folklore in the Himalaya. London: E. Arnold, 1913.

Hardinge of Penshurst, Charles Hardinge, Baron. On hill and plain. London: J. Murray, 1933.

Heber, Reginald. Bishop Heber in Northern India; selections from Heber's journal. Edited by M.A. Laird. London: Cambridge University Press, 1971.

Higginson, Henry A. Two Centuries of Foxhunting. London: St James Place Collins, 1946.

Holt, Richard. Sport and the British: A Modern History. Oxford: Clarendon Press, 1989.

Hussain, Yusuf, ed. News-letters, 1767-1799 (Nawab Mir Nizam Ali Khan's reign). Hyderabad: Central Records Office, 1955.

Ismail, M. M. Col.-Lieut. Call of the Tiger. London: Faber \& Faber, 1964.

Jahangir Emperor. Memoirs of the Emperor Jahangueir. Translated by Major David Price. London: J. Murray, 1829.

Jahangir, Emperor. Tuzuk-iJanagiri-Jahangirnama: Memoirs of Jahangir. Translated by Wheeler M. Thackston. Oxford: Oxford University Press, 1999.

Jouhar. Tezkereh Al Vakiat, or Private Memoirs of the Moghul Emperor Humayun. Translated by Major Charles Stewart. New York: Augustus M. Kelley, 1969.

Khan, Inayat. Shah Jahan Nama. Edited by Z. A. Desai and W. E. Begley. Delhi: Oxford University Press, 1990. 
Kinloch, Alexander. Large game shooting in Thibet and the North West. London:

Harrison, 1869.

Latthe. Memoirs of his Highness Shri Shahu Chhatrapati, maharaja of Kohlapur, vol. 1 \& 2. Bombay: Times Press, 1924.

Lewis, Thomas Herbert Capt. Wild Races of South-eastern India. London: W.H. Allen \& Co., 1870.

MacFarlane, Iris. Daughters of the Empire: A Memoir of the Life and Times in the British Raj. New Delhi: Oxford University Press, 2006.

Mainwaring, Henry Germain. A soldier's shikar trips. London: Grant Richards, 1920.

Miller, Edward Darley. Lieut.-Col. Fifty Years of Sport. London: Hurst and Blackett, Ltd., 1925.

Narayan, R. K. ed. Mahabarata: A shortened Modern Prose Version of the Great Indian Epic. New York: Viking Press, 1978.

Nicholls, Frank. Assam shikari; a tea planter's story of hunting and high adventure in the jungles of North East India. Auckland: Tonson, 1970.

Parker, Eric. Game birds, beasts, and fishes; natural history for sportsmen. Philadelphia: J.B. Lippincott company, 1935.

Parker, Eric. British Sport. London: W. Collins, 1944.

Penny, F. E. On the Coromandel Coast. London: Smith, Elder \& Co., 1908.

Penny, F. E. Southern India. London: A. \& C. Black, 1914.

Prabhupada, Swami Bhaktivedanta A. C. Bhagavad Gita. Bombay: Bhaktivedanta Book Trust, 1983.

Pollok, Fitz William Thomas. Sport in British Burmah, Assam and the Cassyah and Jynthia hills. London: Chapman and Hall, 1879.

Pughe, J.R. Lieut.-Col. Report on the State of Police in the Lower Provinces of the Bengal Presidency for the Year of 1867, Vol. 1. Calcutta: Thomas Smith Press, 1868.

Rana, Ina Shumshere. Those were the days. Kathmandu: Sharda Prakashan Griha, 1977. 
Raoul. Reminiscences of twenty years' pigsticking in Bengal. London: Thacker, Spink \& Co., 1893.

Rashdi, Pir Ali Mohammed. Sindh: Ways and Days: Shikar and other Memories. New York: Oxford University Press, 2003.

Roy, Jit. Shikar Tales by the Barrel. Bombay: Pearl Publications, 1968.

Russell, Charles Edward Mackintosh. Bullet and shot in the Indian forest, plain and hill. With hints to beginners in Indian shooting. London: W. Thacker \& Co., 1900.

Sabretache. Monarchy and the Chase. London: Eyre and Spottiswoode, 1948.

Sanghave, Vias Dr. ed. Papers of Shahu Chhatrapati, Maharaja of Kohlapur, Vol. 1-7. Kohlapur: Shivaji University Press, 1983.

Savory, Isabel. A sportswoman in India: Personal adventures and experiences of travel in known and unknown India. London: Hazell, Watson and Viney, Ltd.,1900.

Shields, Nancy. ed. Birds of Passage: Henrietta's travels in south India 1798-1801. London: Eland, 2009.

Sinha, Bhupendra Chandra. Bana jangala o sikara katha. Bombai: Oriyenta Lammyansa, 1970.

Sinha, Kirtyanand. Purnea: a shikar-land. Calcutta: Thacker, Spink, \& Co., 1919.

Silver Hackle. Indian jungle lore and the rifle. Being notes on Shikar and wild animal life. Calcutta: Thacker and Spink, 1929.

Singh, Arjan. A Tiger's Story. New Delhi: Tara Press, 2005.

Singh, Arjan. Tiger! Tiger!. London: Trinity Press, 1984.

Singh, Bachoo Narain. Narabakshi bagho ka sikara. Illahabada: Lokhabharati Prakasana, 1966.

Singh, Col. Jaipal. Great Hunt, New York: Carlton Press, 1981.

Sitwell, Constance. Flowers and Elephants. London: Jonathan Cape, 1927.

Smythies, Evelyn. Big game shooting in Nepal : with leaves from the Maharaja's sporting diary. Calcutta: Thacker \& Spink, 1942. 
Smythies, Olive. Ten Thousand Miles on Elephants. London: Seeley Service \& Co. Ltd., 1961.

Somerville, Augustus. Shikar near Calcutta : with a trip to the Sunderbunds. Calcutta: W. Newman, 1924.

Sondhi, Ranavira. Camparanya. Mujapharaphura: Sandhya Prakasana, 1967.

Sportsman of Berkshire. Essays on hunting Containing philosophical enquiry into the nature and properties of the scent, observations on different kinds of hounds, with the manner of training them. Also directions for the choice hunter ... . Southampton: T. Baker, 1782.

Stewart, A. E. Tiger and other game: the practical experiences of a soldier shikari in India. London: Longman \& Green, 1927.

Stockley, Charles Hugh. Shikar, being tales told by a sportsman in India. Bombay: Oxford Univ Press, 1928.

Stone, Samuel James. In and beyond the Himalayas; a record of sport and travel in the abode of snow. London: E. Arnold, 1896.

Swain, Clara Dr. A glimpse of India. New York: James Pott \& Co. 1909.

Sympson, William Capt. A New Voyage to the East Indies viz. to Suratte, and the coast of Arabia. London: H. Meere, 1715.

Thapar, Valmik. The Last Tiger: Struggling for Survival. New Delhi: Oxford University Press, 2006.

Thomas, William Beach Sir. Hunting England; a survey of the sport, and of its chief grounds. London: B.T. Batsford Ltd., 1936.

Thorsell, J.W. Ed. "Conserving Asia's Natural Heritage The Planning and Management of Protected Areas in the Indomalayan Realm. " Proceedings of the $25^{\text {th }}$ Working Session of IUCN's Commission on National Parks and Protected Areas Cambridge: IUCN, 1985.

Tulloch, Maurice. The all-in-one shikar book; an everyday guide to field sports in India. Bombay: Taraporevala, 1953.

Turner, J.E. Carrington. Man-Eaters and Memories. London: Robert Hale Ltd., 1959. 
Tytler, Harriet, An Englishwoman in India :the memoirs of Harriet Tytler, 1828-1858. Oxford: Oxford University Press, 1986.

Tyacke, Richard Humphrey, Mrs. How I shot my bears; or, Two years'tent life in Kullu and Lahoul. London: S. Low Marston \& Co., 1893.

Walsh, John Henry. Manual of British Rural Sports: comprising shooting, hunting, coursing, fishing, hawking, racing, boating, pedestrianism, and the various rural games and amusements of Great Britain. London and New York: G. Routledge \& Co., 1856.

Walshe, Blayney Townly. Sporting and military adventures in Nepaul and the Himalayas. A narrative of personal encounters and narrow escapes. London: J. Blackwood \& Co., 1875.

Ward, Geoffrey. Tiger-Wallahs Saving the Greatest of the Great Cats. New Delhi: Oxford University Press, 2000.

Wardrop, A. E. (Alexander Ernest). Modern Pig-sticking. London: Macmillan, 1914.

Williamson, Thomas. Captain. Illustrations of Indian field sports : selected and reproduced from the coloured engravings first published in 1807. Westminister, Eng.: A. Constable, 1892.

Williamson, Thomas Captain. Oriental Field Sports. London: Orme, 1807.

Underhill, George Frederick. A Century of English fox-hunting. London: R.A. Everett, 1900 .

Zetland, Lawrence John Lumley Dundas, Marquis. Sport and politics under an eastern sky. London \& Edinburgh: W. Blackwood and Sons: 1902.

Secondary Sources:

Bailey, Peter. Leisure and class in Victorian England: rational recreation and the contest for control, 1830-1885. London: Routledge \& K. Paul, 1978.

Barton, Gregory. Empire Forestry and the Origins of Environmentalism. Cambridge: Cambridge University Press, 2002.

Barr, Pat. The Memsahibs: the women of Victorian India. London: Century, 1989. 
Beaver, Dan C. Hunting and the politics of violence before the English Civil War. Cambridge: Cambridge University Press, 2008.

Beinart, William and Lotte Hughes eds. Environment and Empire. Oxford: Oxford University Press, 2007.

Burton, Antoinette. Burdens of History: British Feminists, Indian Women and Imperial Culture, 1868-1915. Chapel Hill, University of North Carolina Press, 1994.

Callaway, Helen. Gender, Culture and Empire: European Women in Colonial Nigeria. Urbana: University of Illinois Press, 1987.

Cannadine, David. Ornamentalism: How the British Saw their Empire. Oxford: Oxford University Press, 2002.

Carr, Raymond. English Fox Hunting: A History. London: Weidenfeld \& Nicolson, 1976.

Chatterjee, Partha. "A Nation and Its Women." In A Subaltern Studies Reader, 1986-1995, ed. Ranajit Guha, 240-262. Minneapolis: University of Minnesota Press, 1997.

Chaudhuri, Nupur and Margaret Stroebel Eds. Western Women and Imperialism: Complicity and Resistance. Bloomington: University of Indiana Press, 1992.

Cohn, Bernard. Colonialism and its forms of knowledge. Princeton: Princeton University Press, 1996.

Colley, Linda. Captives: Britain, Empire, and the World, 1600-1850. NY: Anchor Books, 2002.

Conklin, Alice ed. European Imperialism. Boston: Houghton Mifflin, 1999.

Cummins, John. The Hound and the Hawk: The Practice and Meaning of Medieval Hunting. NY: St. Martin's Press, 1989.

Dewey, Clive. Anglo-Indian attitudes: the mind of the Indian Civil Service. London: Hambledon Press, 1993.

Drayton, Richard. Nature's Government: Science, Imperial Britain and the Improvement 
of the World. New Haven: Yale University Press, 2000.

Ghose, Indira. Memsahibs abroad: writings by women travelers in nineteenth century India. Bombay: Oxford University Press, 1998.

Ghosh, Durba. Sex and the Family in Colonial India: the making of Empire. Cambridge: Cambridge University Press, 2006.

Gilbert, John M. Hunting and Hunting Reserves in Medieval Scotland. Edinburgh: John Donald, 1979.

Griffin, Emma. Blood Sport: Hunting in Britain Since 1066. New Haven: Yale University Press, 2007.

Grove, Richard. Green Imperialism: Colonial Expansion, Tropical Island Edens, and the Origins of Environmentalism, 1600-1860. Cambridge: Cambridge University Press, 1995.

Guha, Ranajit. “Chandra's Death.” In A Subaltern Studies Reader, 1986-1995, ed. Ranajit Guha, 34-62. Minneapolis: University of Minnesota Press, 1997.

Guha, Ranajit and Madhav Gadgil. This Fissured Land: An Ecological History of India. Berkeley: University of California Press, 1992.

Hodge, Joseph M. Triumph of the Expert: Agrarian Doctrines of Development and the Legacies of British Colonialism. Athens: Ohio University Press, 2007.

Holt, Richard. Sport and the British: A Modern History. Oxford: Clarendon Press, 1989.

Hyam, Ronald. Empire and Sexuality: The British Experience. Manchester: Manchester University Press, 1990.

Itzkowitz, David C. Peculiar Privilege: A Social History of English Foxhunting, 1753-1885. Hassocks: Harvester Press, 1977.

Jayawardena, Kumari. The white woman's other burden: Western women and South Asia during British Rule. (New York: Routledge, 1995). 
Lewis, Michael. Inventing Global Ecology: Tracking the Biodiversity Ideal in India, 1947-1997. Athens: Ohio University Press, 2004.

Levine, Phillippa, ed. Gender and Empire. Oxford History of the British Empire Companion Series. Oxford: Oxford University Press, 2007.

Lind, Mary Ann. Compassionate Memsahibs: Welfare Activities of British Women in India, 1900-1947. New York: Greenwood Press, 1988.

MacKenzie, John. The Empire of Nature: Hunting, Conservation and British Imperialism. Manchester: Manchester University Press, 1988.

Manning, Roger B. Hunters and Poachers: A Cultural and Social History of the Unlawful Hunting in England, 1485-1640. Oxford: Clarendon Press, 1993.

McClintock, Anne. Imperial Leather: Race, Gender and Sexuality in the Colonial Contest. New York: Routledge, 1995.

Midgley, Claire, ed. Gender and Imperialism. Manchester: Manchester University Press, 1998.

Orwell, George. Burmese Days; Keep the aspidistra flying; Coming up for air. NY: Alfred A. Knopf, 2011.

Metcalf, Thomas. Ideologies of the Raj. Cambridge: Cambridge University Press, 1996.

Ofcansky, Thomas. Paradise Lost: A History of Game Preservation in East Africa. Morgantown: West Virginia Press, 2002.

Patterson, Steven. The Cult of Imperial Honor in British India. New York: Palgrave Macmillan, 2009.

Pelikan, Jarislav, ed. Sacred Writings of the Rig Veda. Delhi: Motilal Barasidas, 1992.

Possehl, Gregory. "Harappans and hunters: economic interaction and specialization in prehistoric India." In Forager-Traders in South and Southeast Asia, Eds. Kathleen D. Morrison and Laura L. Junker, 62-76. Cambridge: Cambridge University Press, 2002.

Procida, Mary. Married to the Empire: Gender, Poltiics and Imperialism in India, 
1883-1947. Manchester: Manchester University Press, 2002.

Rangajaran, Mahesh. "The Raj and the Natural World: The War against 'Dangerous Beasts' in Colonial India." In Wildlife in Asia: Cultural Perspectives, ed. John Knight, 207-232. New York: Routledge, 2004.

Rangarajan, Mahesh. Oxford Anthology of Indian Wildlife, Vol. 1 Hunting and Shooting. Oxford and New York: Oxford University Press, 1999.

Reid, Douglas. "Beasts and Brutes: popular blood sports, c. 1780-1860." In Sport and the working class in Britain, ed. Richard Holt, 12-28. Manchester: Manchester University Press, 1990.

Richards, John. The Mughal Empire. Cambridge: Cambridge University Press, 1995.

Said, Edward. Orientalism: Western Conceptions of the Orient. New York : Penguin 1995.

Schimmel, Anne Marie. Great Mughal Empire: History, Art and Culture. London: Reaktion Books, 2004.

Sen, Indrani. Woman and Empire: Representations in the Writings of British India 1858-1900. Hyderabad: Orient Longman, 2002.

Sinha, Mrinalini. Colonial Masculinity: The 'Manly Englishman' and the 'Effeminate Bengali' in the Late Nineteenth Century. Manchester: Manchester University Press, 1995.

Spear, Percival. The Nabobs: a study of the social life of the English in eighteenth century India. Oxford: Oxford University Press, 1998.

Steinhart, E.I. Black Poachers, White Hunters: A Social History of Hunting in Colonial Kenya. Athens: Ohio University Press, 2005.

Streets, Heather. The Martial Races: The Military, Race, and Masculinity in British Imperial Culture, 1857-1914. Manchester: Manchester University Press, 2005.

Stroebel, Margaret. European Women and the Second British Empire. Bloomington, Ind.: University of Indiana Press, 1991.

Thomas, Richard. The Politics of Hunting. Aldershot, Eng.: Gower, 1983. 
Thompson, E.P. Customs in Common: Studies in Traditional Popular Culture. London: New Press, 1993.

Thompson, E.P. Whigs and Hunters: The Origin of the Black Act. New York: Pantheon Books, 1975.

Trollope, Joanna. Brittania's Daughters: Women of the British Empire. London: Hutchinson \& Co., 1983.

Vale, Marcia. The Gentleman's Recreations: accomplishments and pastimes of the English gentleman, 1580-1630. Cambridge: D. S. Brewer, 1977.

Woollacott, Angela. Gender and Empire. New York: Pallgrave Macmillan, 2006.

Articles:

Beinart, William. "Empire, Hunting and Ecological Change in Southern and Central Africa." Past and Present, 128 (1990), 162-186.

Brittlebank, Kate. "Sakti and Barakat: The Power of Tipu's Tiger: An Examination of the Tiger Emblem of Tipu Sultan of Mysore." Modern Asian Studies 29, 2 (May 1995): 257-269.

Chaudhuri, Nupur. "Memsahibs and Motherhood in Nineteenth-Century Colonial India." Victorian Studies 31.4 (1988): 517-535.

Eaton, Natasha. "Between Mimesis and Alterity: Art, Gift, and Diplomacy in Colonial India, 1770-1800." Comparative Studies in Society and History 46(4) October 2004: 816-844.

Loo, Tina. "Of Moose and Men: Hunting for Masculinities in British Columbia, 1880-1939." Western Historical Quarterly, Vol. 32, No. 3 (Autumn 2001): 297-319.

MacKenzie, John. "The Imperial Pioneer and Hunter and the British Masculine Stereotype in late Victorian and Edwardian Times, " Manliness and Morality: Middleclass Masculinity in Britain and America, edited by J.A. Mangan and J. Walvin, 176-198. Manchester: Manchester University Press 1987.

Mangan, J.A. and C. McKenzie. "Imperial Masculinity Institionalized; The Shikar Club." International Journal of the History of Sport. 25, 9 (2008): 1218-1242.

Nongbri, Natasha. "Elephant Hunting in Late $19^{\text {th }}$ Century North-East India Mechanisms of Control, Contestation and Local Reactions." Economic and Political Weekly, July 26, 2003: 3189-3199.

Sivaramakrishnan, K. "Science, Environment and Empire History: Comparative Perspectives from Forests in Colonial India." Environment and Empire 14 (2008): 41-65. 
Sramek, Joseph. “'Face him like a Briton': Tiger Hunting, Imperialism, and British Masculinity" in Colonial India, 1800-1875." Victorian Studies 48, 4 (Summer 2006): 659-680.

Steinhart, E.I. "Hunters, Poachers, and Gamekeepers: Towards a Social History of Hunting in Colonial Kenya." Journal of African History, 30(1989), 247-264.

Storey, W.K. "Big Cats and Imperialism: Lion and Tiger Hunting in Kenya and Northern India, 1898-1930.” Journal of World History (1991): 135-173.

Zastoupil, Lynn. "Intimacy and Colonial Knowledge." Journal of Colonialism and Colonial History, 3, 2 (2002).

Unpublished sources:

Hughes, Jeffrey. "Shah Jahan's Lal Mahal at Bari and the Tradition of Mughal Hunting Palaces” PhD diss., University of Iowa, 1988.

Ingram, Darcy. "Nature's improvement: Wildlife, conservation, and conflict in Quebec, 1850-1914.” PhD diss., McGill University, 2007.

Kelly, Tara Kathleen. "The hunter elite: Americans, wilderness and the rise of the biggame hunt.” PhD diss., John Hopkins University, 2007. 